\title{
Livestock production
}

and Sahelian rangelands potential

$$
\text { - SUDAN - }
$$




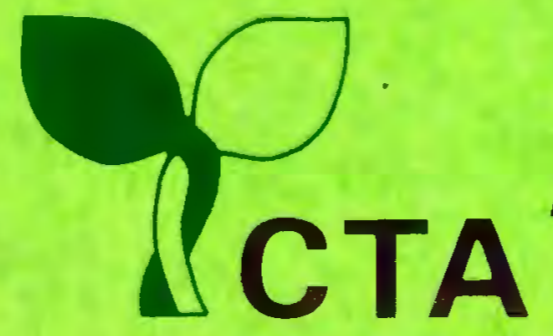

TECHNICAL CENTRE FOR

AGRICULTURAL AND RURAL COOPERATION

$$
\text { ACP - EEC }
$$




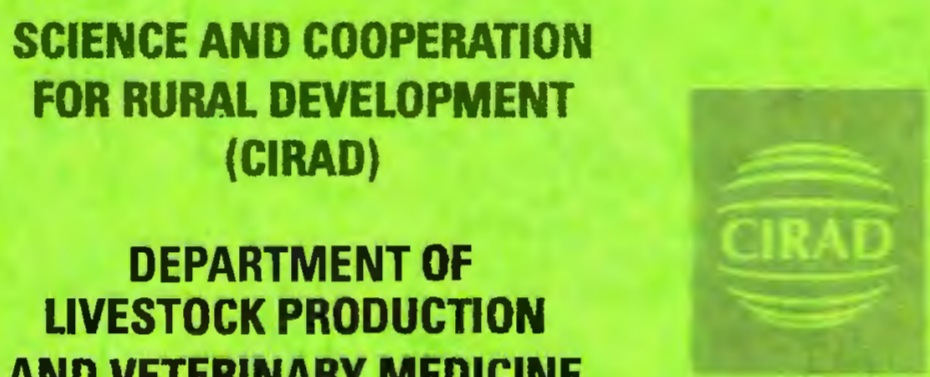
AND VETERINARY MEDICINE (CIRAD - EMVT) 


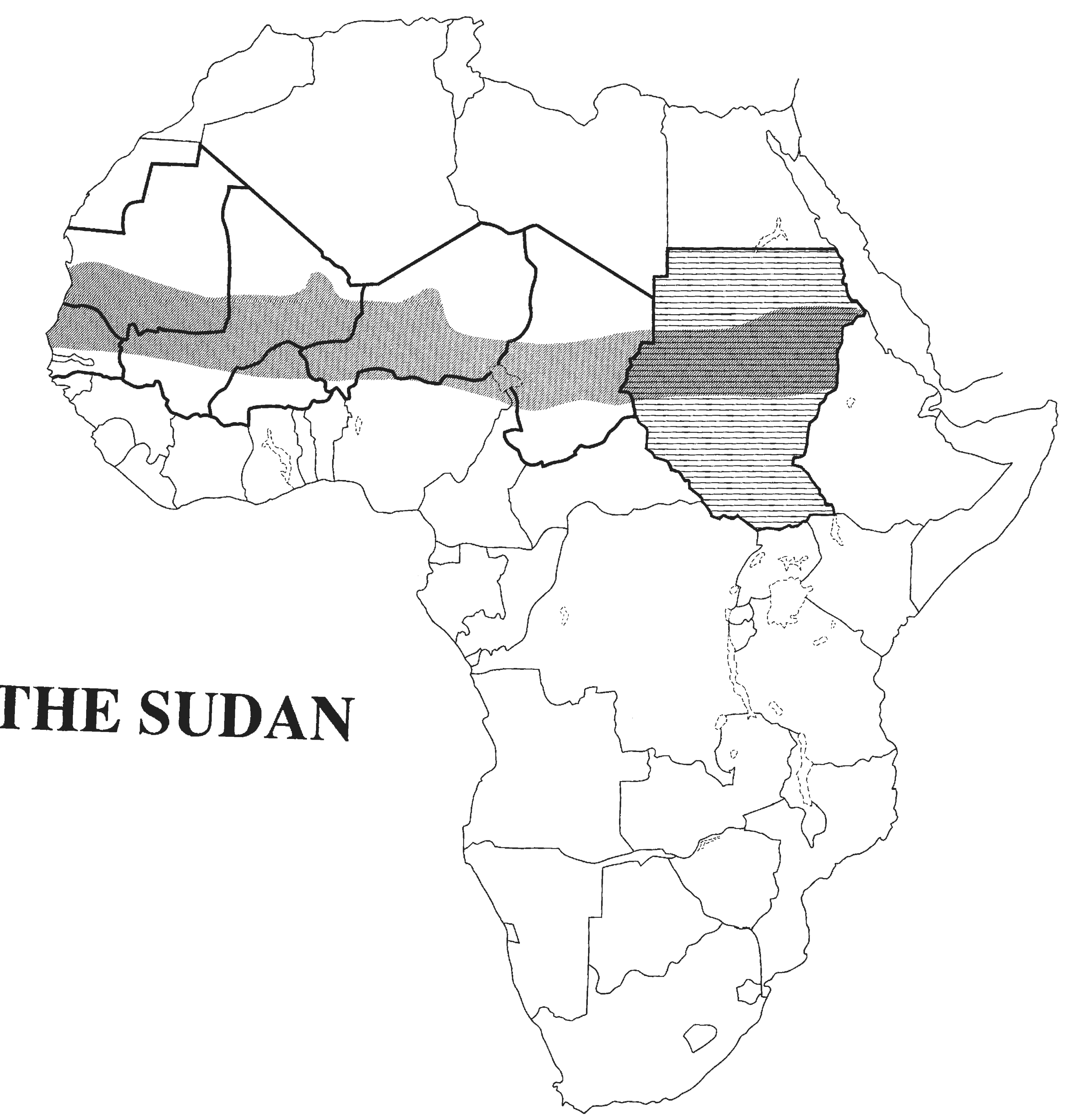




\section{FOREWORD}

On behalf of my Ministry I should like to thank CTA for sponsoring the production of this useful series of Atlases on the rangelands of the Sahelian zone of Africa, and especially for this volume covering Sudan. Our thanks are also extended to CIRAD/ EMVT. The Atlas will be a great help to land-use planners, specialists, and all those who are involved in rangelands and livestock development.

Agriculture, including livestock, accounts for about one third of Sudan's GDP and over $90 \%$ of its exports. It provides employment for about $70 \%$ of the labour force. Stock-rearing plays an important role in the economy of Sudan. It accounts for about $35 \%$ of agriculture's GDP and is the second most important foreign exchange earner after cotton, accounting for about $10 \%$ of total export value.

According to $1988 / 89$ figures, the total livestock population was estimated at $\mathbf{2 0 . 1 7}$ million cattle, 19.67 million sheep, 14.48 million goats, and 2.73 million camels.

Livestock production depends entirely upon the rangelands, and livestock derive about $85 \%$ of their feed from natural range resources, $10 \%$ from crop residues and by-products and $5 \%$ from irrigated forages and concentrates.

Livestock production and sahelian rangelands potential: Republic of Sudan. Darag A., Forgiarini Giordano, Lamarque Georges. 1993. Wageningen : CTA-CIRAD-IEMVT, 33 p. ISBN 2-85985-121 ; 2-87614-088-8 
Livestock production can be classified into six systems: nomadic pastoral, transhumant pastoral, semi-sedentary and sedentary traditional, integrated intensive livestock/crop production, commercial fattening and poultry production, and intra-urban backyard production.

Due to different environmental conditions resulting from the actions and interactions of climate, soils, topography and the predominant land uses, some 30 years ago range resources were classified as desert, semi-desert, low rainfall savanna, high rainfall savanna, flood regions and mountain vegetation.

Rangeland is used as common property and consequently this open use has lead to range degradation, particularly around permanent water supply centres. Uncontrolled fires and overgrazing are among several factors that caused range deterioration and desertification.

The Government's policy is now oriented towards the creation of the High Council for Natural Resources and Environment. The Council is expected to establish a clear and well-defined land use policy and to create strong cooperation between different government bodies involved in natural resources utilization, conservation, rehabilitation and development. The Council will assist in the establishment of a Grazing Act that will define the role and functions of the Range and Pasture Administration.

Dr. Abu El Gasim Ahmed Shommo

State Minister for

Agriculture, Natural and Animal Resources

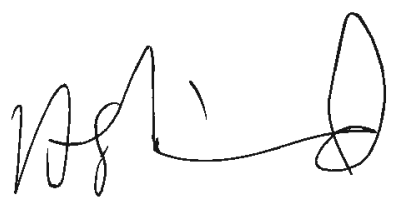




\section{INTRODUCTION}

The CTA (Technical Centre for Agricultural and Rural Cooperation) was created in 1983 under provisions of the Second Lomé Convention. Its mandate is to ensure efficient exchange of information among the member states of the ACP (Africa, Caribbean, Pacific) with a view to encouraging agricultural and rural development.

Among the principal objectives and priorities with which the Centre is charged, is the preparation of syritheses, in an accessible and readily available form, of information that has already been gathered but which is often widely dispersed and difficult to obtain.

The question then to be asked was: which information would be the most useful?

In 1983 the prolonged drought was still exacting its heavy toll on Africa, in particular in the Sahel countries. Desertification continued its inexorable march to the south, vast areas of land were degraded, and whole vegetation communities were being wiped out. It was thought necessary, then, to gather together information that would be of assistance in the design of new development strategies. The preparation and publication of a simple but complete document that would synthesize all that was known of the rangelands of the Sahel was considered a key aspect in the formulation of such a strategy.

In the face of these facts, would an atlas summarizing all the data available be useful; and why would it be so?

Many factors lay behind the decision to proceed with the production of such an atlas. The first was that the Sahel is not totally damned and that the drought, although it would need certainly to be taken into account in any strategy and any rational management plan for the rangelands, would not last for ever. Wet and dry periods would succeed each other, as they have always done, and rangeland productivity would likewise fluctuate from high in good years to low or even very low in bad years. The second was that there was a real need for all the information accumulated over years of work to be brought together and consolidated, for any new strategy would obviously need to take account of acquired experience.

Certainly, there were many gaps in what was known. Filling these gaps and bringing everything up-to-date would have caused many problems and been a long-term exercise. It was decided that the search for perfection would have to be put aside for the time being as it would have been a major impediment to the timely publication of what was already known and to the information distribution process. In any case, it is in the nature of things that all up-to-date publications become very quickly out-of-date. Graphs and maps often depict unstable situations but have the advantage that they highlight what has not been done and can lead to what needs to be done then being done in the continued striving for a perfect product. So, in spite of changes which are known to have occurred to the ecology of the area, the justification for this atlas is the use which will be made of it by planners and developers. 
Within the context of a pastoral atlas it was apparent that other subjects closely related to the management of the rangelands would need to be included. This is in order that the range can truly be regarded as a component of livestock production and as a tool, or a resource, that livestock owners use to gain their livelihood.

The series of atlases that has already been published covers all the French-speaking countries of the Sahel. It is therefore logical that the major English-speaking "Sahel" country should be the subject of an additional volume and that this volume should be presented in the same format as all the others. This atlas on the Sudan has been the subject of special effort, not only because the

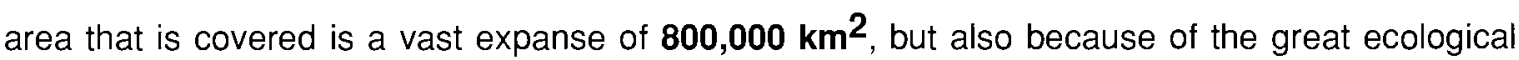
and environmental diversity that are features of this area. The pastoral systems of the Sudan are also diverse, stemming as they do from a variety of historical and ethnic situations. Finally, while there is a great deal of information on the Sudan's pastoral areas, much of it is relatively old, incomplete or preliminary, often contradictory, and has rarely been up-dated.

The climatic range in the Sudan, as in the other Sahelian countries, covers the whole gamut from hyper-arid desert to humid savanna: further variety is added by the variations due to altitude. There are differences between the rocky and sandy areas of the uplands and the clay plains of the Nile basin, the one or two volcanic areas again adding another dimension.

There should be no surprise, therefore, that the map at a scale of 1: 500,000 describes 80 distinct range types, even though a special effort was made to reduce these to a manageable and "userfriendly" number. The ecological typology that has been adopted, and which is derived from the information that has been gathered previously, is and essential prerequisite to the detailed study of the rangelands on which the animals survive and produce. The nutritional values of the pastures are presented in quantitative terms but these are complemented by some qualitative information, especially in view of the fact that it is the limits imposed by protein availability - or the lack of it that largely govern improvements in animal productivity.

It is clear that the current stocking rate is very close to the carrying capacity of the pastoral areas. This is particularly so as rangeland production is, at least temporarily, not at its potential due to the sequence of drought years and the impact of large animal numbers. One of the features of the atlas resulting from this is a map showing the degree of degradation in various areas.

Cultivated areas are expanding very rapidly in the area that is covered by this atlas. This obviously has major implications for livestock production. The situation in the Sudan is somewhat different from that found over much of the rest of the Sahel because, in addition to traditional agricultural systems, there are large areas of irrigated and mechanized agriculture. Underground and surface water resources have also been extensively tapped and harnessed by the construction and equipping of hundreds of boreholes, wells and dams. 
Livestock owners comprise $\mathbf{4 0 \%}$ of the population of the zone. Many are specialists in different forms of livestock, from the camel nomads in the north to cattle herders in the more-favoured southerly zones. Most, however, maintain a mixed species herd. The social systems of these different groups have often developed to take account of the composition and productivity of their herds.

Seasonal movements from the "dar" - the tribal homeland - are still a basic feature of northern Sudan's pastoral systems and are indeed essential to the productivity and even the survival of the herds and of the pastoral way of life. Recent developments have, however, created major problems for the transhumant system, not only in the use of the rangelands but also in the very social fabric of the communities that use them.

Sudan has several important breeds of livestock that are productive and well adapted and resistant to the rigorous conditions under which they are raised. These include, among the cattle, the Kenana, Butana and Western Baqqara types. The various subtypes and tribal varieties of the Sudan Desert sheep and the Sudan Desert and Nubian goats are also justly appreciated for their hardiness and productivity. Livestock production in the Sudan is not only owners and animals, however. It is intimately related to and influenced by the well-organized and efficient veterinary services. These services have a network of posts and stations, in particular placed along the major stock routes and in the main pastoral areas. The Sudan also has a diagnostic veterinary laboratory and a vaccine production unit. It is appropriate, therefore, that the final section in this atlas is devoted to the constraints to livestock production that are imposed by the animal health situation.

This atlas and work of reference results from international cooperation among specialists from the Sudan, from France and from the United Kingdom of Great Britain and Northern Ireland. Several organizations and universities in the United Kingdom have contributed over the years to the enormous data base on which this atlas is based, a contribution that is only partially apparent from the reference lists which accompany the various chapters. Most of the chapters themselves have been written by Sudanese scientists who have been able to benefit from the opportunity provided to them through the technical assistance of CTA and CIRAD-EMVT. 
Financed by:

Technical Centre for Agricultural and Rural Cooperation (CTA)*

Produced by :

Department of Livestock Production and Veterinary Medicine, Centre for International Cooperation in Agricultural Development Research (CIRAD/EMVT) $^{* *}$

in collaboration with the Range Pasture Administration of the Sudan.

The section on water resources was produced by:

Geological and Mining Research Bureau (BRGM) ${ }^{\star \star \star}$ 
${ }^{*}$ CTA :

"De Rietkampen", Galvanistraat 9, EDE

Adresse postale: Postbus 380, 6700 AJ WAGENINGEN, PAYS - BAS

Téléphone : 08380 - 60400 - International 31 - 8380 - 60400 - Telex : 30169

Télécopie : (31) (0) 8380 - 31052

\title{
** CIRAD /EMVT :
}

10, rue Pierre Curie, 94704 MAISONS - ALFORT Cedex

Département Elevage et Medecine Vétérinaire du CIRAD*

Téléphone : (1) 43688873 - Telex EMVT : 262017 F - Télécopie : (1) 43752300

CIRAD* Centre de Coopération Internationale en Recherche Agronomique pour le Développement

\author{
***BRGM : \\ Service Géologique National \\ BP 600945060 ORLEANS Cedex 2 - Téléphone : (38) 643434
}


Acknowledgements: CIRAD-EMVT wishes to thank the following for the assistance they have provided in the production of this atlas:

\section{United Kingdom:}

NRI (Natural Resources Institute)

ODA (Overseas Development Administration)

\section{DURHAM UNIVERSITY}

\section{BANGOR UNIVERSITY}

\section{Republic of the Sudan:}

Ministry of Agriculture and Natural and Animal Resources

Forestry Department

Rural Water Department

\section{AUTHORS:}
A. Darag;
DVM, Director, Range Pasture Administration
F. El Moulah; Range scientist, Range Pasture Administration
G. Forgiarini; Remote sensing specialist, CIRAD-EMVT
H.I. Khatab; DVM, Ministry of Agriculture and Natural and Animal Resources
G. Lamarque; Cartographer, CIRAD-EMVT
M. El Sammani; Socio-économist, University of Khartoum
G. Tacher; Director, CIRAD-EMVT
H. Torrent; Hydrogeologist, BRGM
G. Uilenberg; Scientific Director ( Animal Health ), CIRAD-EMVT

\section{SCIENTIFIC EDITORS:}
J. C. Bille;
Range ecologist
R. T. Wilson;
Animal scientist/natural resources ecologist

TECHNICAL PRODUCTION:

\section{Range maps}
Interpretation:
G. Forgiarini, CIRAD-EMVT
Drawing:
N.Fontaine, CIRAD-EMVT 


\section{Other maps}

Design and production: I. de Zborowski, CIRAD-EMVT

Art work : N. Fontaine, L. Renvoisé, A. Borg, V. Verdier, G. Legrand, CIRAD-EMVT.

Word processing and type setting: by the technical services of CIRAD-EMVT.

Technical coordination: $\quad$ G. Lamarque.

Colour separations for the range map at 1: 500,000 by Systèmes Graphiques et Cartographiques * using the BARCO programme.

*SGC : 7-9. Rue Domremy 75013 Paris

The topographic and toponymic foundations of the range maps at the scale of 1: 500,000 were compiled from:

ONC maps published by the American Aerospace Centre; the International World Map at 1: 1,000,000 published by the Sudan Survey Department;

Michelin map, East and North-East Africa at 1:4,000,000; general map of the Sudan at 1: 3,000,000; and LANDSAT imagery for the years 1986 and 1987.

The frontiers and boundaries marked on the maps in this atlas do not imply the expression of any opinion what so ever by the publishers on their legal standing.

Informations in the text and opinions expressed there are in the sole responsibility of the authors. 


\section{SUMMARY}

General presentation - A. Darag

Text

Phytogeography and botany - A. Darag

Text

Phytogeography and botany

$1 / 3000000$ maps

Phytogeography and botany

Text continued

Satellite Imagery and Cartography - G. Forgiarini, G. Lamarque

Text and 1/500 000 map

1/500 000 Rangeland map legend

Ed Damer Sheet 1/500 000

Atbara

Kutum

Malha

Sodiri

Khartoum

Kassala

Nyala

El Fasher

El Obeid

Kosti

Gallabat

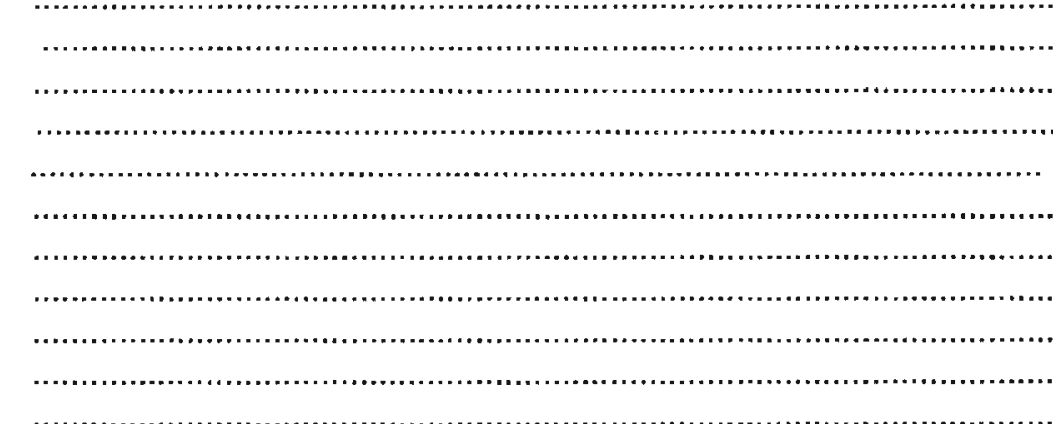

Climate and soils - M. Fald El Moulah

Text and 1/3000 000 map

Climate and soils

Text continued

Feed resources - A. Darag - M. Fald El Moulah

Text

Feed resources

Text continued and $1 / 5000000$ map

Range use - H.I. Khatab - M. Fald El Moulah

Text

Range use

Text continued and 1/5000 000 map 
Cropping

Text continued

Livestock water Supply - H. Torrent

Text

Livestock water Supply

Text continued and 1/5000 000 maps

Pastoral production and economy - M.O. El Sammani

Text and 1/ 3000000 map

Pastoral production and economy

Text continued

Pastoral production and economy

Text continued

Livestock movements - M.O. El Sammani

Text

Livestock movements

Text continued and 1/3000 000 map

Livestock resources - H.I. Khatab

Text

Livestock resources

Continued - 1/3000 000 map

Livestock resources

Text continued

Animal health - H. I. Khatab - G. Uilenberg

Text and 1/3000 000 map

Animal health

Text continued

Veterinary services - H.I. Khatab - M.O. El Sammani

Text 


\section{GENERAL PRESENTATION}

\section{A. DARAG}

Sudan, with an area of more than $\mathbf{2 . 5}$ million $\mathbf{~ k m}^{2}$, is Africa's largest country. It extends from $4^{\circ} \mathrm{N}$ - almost on the equator - at its southernmost extremity, to $22^{\circ} \mathrm{N}$ - almost to the Tropic of Gancer - in the north. This area encompasses a range of widely diverse climatic conditions. With the exception of a $900 \mathrm{~km}$ stretch of coastline along the Red Sea to the north-east, the country is land-locked. The Ethiopian highlands lie to the east, the land rising sharply to high elevations; Kenya and Uganda are to the south, with access through the Upper Nile valtey; the border with Zaire and the Central African Republic follows the Nile-Congo watershed to the south-west. To the north and norh-west, the boundaries with Chad, Libya and Egypt through the Nubian and Libyan deserts are mainly drawn along lines of latitude and longitude. Lying at the contact between tropical black Africa and Arab and Mediterranean northern Africa, the country naturally has a very heterogeneous population.

\section{Physical features}

Sudan is a generally flat or gently sloping and featureless plain reflecting the underlying ancient continental Basement complex rocks. The Basement series is overlain by the Nubian sandstones in the north, and by the Umm Ruwaba formations in the south. Elevations are mostly below $1000 \mathrm{~m}$ in central Sudan, except for the Nuba mountains which reach $1457 \mathrm{~m}$. Higher lands are found around the periphery of the country. Jebel Marra, close to Chad in the west, is an extinct volcano culminating at $3042 \mathrm{~m}$ and surrounded by lava plateaux. The bare and rocky Red Sea hills rise some $2000 \mathrm{~m}$ above narrow and inhospitable coastal plains, and there are a few higher ranges scattered along the Ethiopian foothills. The highest point in Sudan is Mount Kinyeti ( $3198 \mathrm{~m}$ ) in the Imatong mountains on the Uganda border.

The major differentiation of soils within the country is the sharp contrast between the clay plains along the Nile and its tributaries, and the surrounding lands. The clays, often dark-coloured and cracking, cover part of the central region and Kassala Province and extend over most of the southern regions where the rivers meander across vast areas of swamps and papyrus marshes. The southern swamps are referred to as the Sud (Arabic = dam), the name being derived from the accumulations of vegetation which block the rivers after the rains. The Bahr el Ghazal basin is flooded from August to November, then dries out into tall grasslands. The Bahr el Jebel, south of Lake No, and the Sobat basins have many permanent swamps. The land above the plains is a wooded or forested lateritic plateau in the south, whereas the northern areas are sandy or rocky tablelands. Southern Kordofan and Darfur and the southerly parts of Northern Kordofan and Darfur are mainly of Qoz, once mobile but now low, fixed sand dunes of short grass savanna.

The flat nature of the whole country is emphasized by the very small fall of the Niles from south to north. The Blue Nile crosses the Ethiopian border at $500 \mathrm{~m}$ above sea level, then flows $2000 \mathrm{~km}$ through the cowntry to reach Lake Nubia and the border with Egypt at an elevation of $180 \mathrm{~m}$; the White Nile falls only $17 \mathrm{~m}$ over its $1700 \mathrm{~km}$ course from the Uganda/Sudan border to Khartoum. The White Nile is navigable throughout the year from Lake No to Khartoum. Farther downstream the lower course is interrupted by cataracts where the wide valley is reduced to narrow gorges.

\section{The Nile system}

The Nile is an international river system and Sudan controls only its middle sections. The Nile, however, dictates the present and future land use of the country, and provides 96 per cent of an average annuel surface rum-off estimated at $136.5 \mathrm{~km}^{3}$. The White Nile rises from, and its flow is regulated by, Lake Victoria: some $23 \mathrm{~km}^{3}$ of water cross the Uganda border annually. The water slowly spreads in the southem swamps which also collect water from the western tributaries, the whole contributing to the delivery of a steady discharge throughout the year. The Sobat, a perennial river flowing out of southern Ethiopia, brings an additional $13.5 \mathrm{~km}^{3}$ per year. The total annual flow at Malakal is $27.5 \mathrm{~km}^{3}$, of which $2.5 \mathrm{~km}^{3}$ evaporate before reaching the regulating dam of Jebel Aulia. 
The Blue Nile is sustained by the monsoon rains over the Ethiopian highlands. It provides an average 60 per cent of the total flow at Khartoum, where its level rises by $7 \mathrm{~m}$ in August, and it supports 40 per cent of the currently irrigated area. Its regime is extremely variable, however, with the annual discharge ranging from 40 to $150 \mathrm{~km}^{3}$. The heavy rains cause the river to start flooding in July. Flow is at a maximum by the end of August and remains high until mid-October.

The other east bank affluents, mainly the Atbara, Rahad and Dinder rivers, are seasonal. Taken together they add $16 \mathrm{~km}^{3}$ to the system, so that an annual average of $86.5 \mathrm{~km}^{3}$ flows past Atbara, of which $84 \mathrm{~km}^{3}$ eventually reach Lake Nubia. These date are summarized in Table 1.

The Nile system thus makes an enormous amount of water available for human needs. Efforts are constantly being made to reduce water losses by seepage and evaporation even though Sudan does not yet use all of the annual $18.5 \mathrm{~km}^{3}$ which are its share of the Nile waters, as determined by the 1959 agreement with Egypt. The Jonglei canal, when completed, will conserve $33 \mathrm{~km}^{3}$ of water otherwise lost in the Sudd, and the Machar swamps could also yield about $4 \mathrm{~km}^{3}$ every year.

Table 1 : Average annual discharge of the Nile system (values represent $10^{9} \mathrm{~m}^{3}$ water)

\begin{tabular}{l|l|c|l|l|c}
\hline \multicolumn{1}{c|}{ Location } & \multicolumn{1}{c}{ River } & Value & Location & Filver & Value \\
\hline Uganda border & White Nile & 23.0 & Juba & White Nite & 26.5 \\
Fangak & Bahr ez Zeraf & 5.0 & Sudd & Bahr el Jebel & 8.5 \\
Bentiu & Bahr el Ghazal & 0.5 & Abwong & Sobat & 13.5 \\
Malakal & White Nile & 27.5 & Er Roseires & Blue Nile & 49.5 \\
Dinder & Dinder & 3.0 & El Hawata & Rahad & 1.0 \\
Khartoum & White Nile & 25.0 & Khartoum & Blue Nile & 51.5 \\
Atbara & Maîn Nile & 74.5 & Atbara & Atbara & 12.0 \\
Shendi & Main Nile & 76.5 & Wadi Halła & Main Nile & 84.0 \\
\hline
\end{tabular}

Source: Rural Water Corporation

A major problem is that of providing an adequate and timely water supply during winter and early summer, when it does not rain, and when irrigation is a necessity for crops. Longer term storage is also required to counterbalance the variability of the Blue Nile, additional to that provided by the reservoirs that have been constructed at Sennar, Er Roseires, Khasm el Girba and Jebel Aulia to contain high floods for use during poorer years. With more water, the capability for Sudan to irrigate larger areas of clay land by gravity in the new irrigation schemes that are currently under development would be increased.

In addition to gravity feed, pump irrigation enables cultivation all along the Niles, including the Guneid sugar-cane operation near Wad Medani. Traditional irrigation methods that use counterweighted hand-scoops (Arabic $=$ shaduf) and animal-powered water-wheels (Arabic $=$ saqqiya) are still extensively employed by small scale producers but both the area watered and the length of the irrigation period are reduced by the increased lift imposed as the river level goes down. Flood irrigation is possible in some areas where the Gash (north of Kassala) and Baraka (in the Tokar area) rivers form flood plains: similarly, part of the flood water of Khor Abu Habl flowing from the Nuba mountains is diverted for crops. Many other smaller and larger valleys are cultivated along the river beds and the major seasonal streams ('wad') often provide sites for falling flood irrigation, especially of sorghum and vegetables.

Away from the Nile system, water is scarce except for a short period when rainfall exceeds infiltration into the ground, and when temporary drainage lines ('khor' and 'wad') are converted into wild torrents. The water table is often close to the surface along the wadi beds and their terraces, even in the northern areas, and shallow wells can be dug to provide permanent water to villages. Soil structure and texture influence the availability of water: on sands and gravels seepage is intense, the Qoz sands providing a good example of such a situation and having no clear drainage 
pattern. Clays become totally impermeable after the first rains have filled the deep cracks. Waterlogging is common in depressions in the clay areas although the deeper layers of soil still suffer water deficiency which limits tree growth. Consequent on these characteristics, rainfall in northern Sudan is considered 50 per cent more effective on sands than on clays. Water is sometimes collected in shallow artificial ponds (Arabic = 'hafir') when the soil characteristics are favourable and stored through much of the dry season. Many such ponds have been excavated but water losses are considerable and useful life is reduced by rapid infilling through siltation.

\section{A long history}

Sudan's early history is closely linked to Egypt: ancient Sudan, or Punt as the pharaonic people called it, was part of the Egyptian kingdom during the IV th Dynasty, some 4600 years ago. Egyptian control reached upstream on the Nile to Abu Hamad and records describe exploration and trading parties as far south as the Bahr el Ghazal.

Sudan provided goid, ebony, ivory and various game products to its neighbours. The Sudanese people, the Nubians, were employed in Egypt as civil servants or soldiers and there was constant and intimate contact between the Lower Nile populations and their southern allies. The Kingdom of Kush became independent almost 3000 years ago, with its first capital at Napata. One powerful ruler, Piankhi, conquered Egypt and established the XXVth Dynasty but his successors were defeated by the Assyrians in Palestine and pushed out of Egypt.

Kush extented from Dongola to Sennar, possibly even to Malakal and Er Roseires. Its capital was destroyed about 2600 years ago and moved to Meroë which was already an important ironsmelting centre. Trade links between Africa and the Mediterranean world were enhanced as a result of this move. The Kuskites used hieroglyphs like the Egyptians and their funerary rites, including the construction of pyramids, were similar. When the Romans occupied part of the country, Kush broke up into several smaller states, including Alwash, Nobatia and Mugurrah. The area was converted to coptic Christianity, with rites similar to those prevailing today in Ethiopia and Egypt, in 548 A.D., and the new kingdoms of Soba and Dongola were born. A century or so later, the Arabs extended their influence into this region of Africa and all the local states embraced Islam following their defeat and fall in 1340 A.D. At about the same time the West African Bornu Empire reached Darfur and the Fung monarchs created the kingdom of Sennar about 1500 A.D.

This geopolitical situation prevailed until 1821 A.D., when Mohamed Ali, the Ottoman Viceroy of Egypt, conquered the Sudan. The Islamic faith became more developed and the Turkish Ottomans created the embryonic Khartoum. Resentment against the invaders gradually grew among the whole population until, in 1881 A.D., the Sudanese led by Mohamed Ahmed al-Mahdi, started a holy war against the Egyptians who appealed to the British for military assistance. The resulting coalition finally defeated the Mahdi and established an Anglo-Egyptian Condominium in 1889, with the administration of Sudan effectively under the control of a British Governor. The country gradually acquired its present boundaries, railways and roads were built, educational and health services were promoted, irrigation was initiated and the Sudanese were gradually encouraged to become involved in the management of their own land. The passage of time and natural evolution resulted in political independence for Sudan on 1st January 1956.

\section{The population}

The population of Sudan has increased rapidly during the last 20 years. From 15 million inhabitants in 1970, it grew to 18.2 million in 1976, and to 20.5 million in 1983 . The current estimate is 27.3 million. A rate of growth of about 3 per cent per annum is being maintained. The birth rate is very high (446 per 1000 during 1985-1990) and the average number of children per woman is 6.4 At these rates the population is expected to double every 25 years. About 45 per cent of the population is under 15 years and only 14 per cent is over 45 years. Urban areas account for 29.4 per cent of the population. 
Many ethnic groups are represented in the Sudanese population and more than 100 languages are spoken. Arabs are the major element, comprising 49 per cent of the total. They live mainly in the northern part of the country, where there are also Nilo-Saharan and Kordofanian minorities.

In the south, Nilotes are dominant and these can be easily recognized from their tall and slender stature. The southerners live in isolated settlements in the clay plains, above flood level. They have developed mixed farming systems which are perfectly adapted to their land. The largest groups are the Dinka (11.5 per cent) and Nuer (4.9 per cent). Several minor tribes are scattered in southern Sudan, including the Zande (2.7. per cent) along the Zaire boundary and the Bari (2.5. per cent). In the far west, the Fur (2.1. per cent) are an important indigenous tribe and others in this region include the Berti and the Daju.

The population is very unevenly distributed (Table 2). The northern provinces are desert or semidesert with a human population density of only $3.4 / \mathrm{km}^{2}$. The three southern regions of Equatoria, Upper Nile and Bahr el Ghazal have less then 26 per cent of the total population at an average density of $11 / \mathbf{k m}^{2}$. Population pressure is comparable in Darfur and Kordofan where 30 per cent of the population live.

In contrast, one-third of the population lives in the central clay plains, which correspond to only 10 per cent of the area of the country. The major cities are located here. These include the "three towns" of Khartoum (480 000 inhabitants in 1983), Omdurman (530 000) and Khartoum North (340 000), as well as Wad Medani (180 000) and Kassala (160 000). Other important towns are Port Sudan, Atbara, El Obeid and Juba.

Table 2: Regions, provinces, areas and population in Sudan

\begin{tabular}{|c|c|c|c|}
\hline Reglon & Hovinces & Area $\mathrm{km}^{2}$ & Population ${ }^{*}(000)$ \\
\hline $\begin{array}{l}\text { Northem } \\
\text { Eastern }\end{array}$ & $\begin{array}{l}\text { Red Sea } \\
\text { Kassala }\end{array}$ & $\begin{array}{l}476040 \\
219920 \\
114154\end{array}$ & $\begin{array}{r}1436 \\
923 \\
2005\end{array}$ \\
\hline Dartur & $\begin{array}{l}\text { Northern Darfur } \\
\text { Southern Darfur }\end{array}$ & $\begin{array}{l}346155 \\
162529\end{array}$ & $\begin{array}{l}1761 \\
2341\end{array}$ \\
\hline Kordofan & $\begin{array}{l}\text { Northem Kordofan } \\
\text { Southem Kordofan }\end{array}$ & $\begin{array}{l}221900 \\
158355\end{array}$ & $\begin{array}{l}2394 \\
1707\end{array}$ \\
\hline Central & $\begin{array}{l}\text { Khartoum } \\
\text { El Gezirah } \\
\text { White Nile } \\
\text { Blue Nile }\end{array}$ & $\begin{array}{l}28165 \\
35057 \\
41825 \\
62135\end{array}$ & $\begin{array}{l}2390 \\
2683 \\
1237 \\
1401\end{array}$ \\
\hline Bahr el Ghazal & & 200894 & 3004 \\
\hline Upper Nile & & 238312 & 2121 \\
\hline Equatoria & & 197969 & 1865 \\
\hline Total & & 2503410 & 27268 \\
\hline
\end{tabular}

Note : * 1989 estimate

\section{Economy}

Sudan's economy is based primarily on agriculture and pastoralism. These together contribute 35 per cent of GNP and employ 70 per cent of the labour force. Most of the livestock is raised under nomadic or semi-nomadic conditions but these are gradually becoming sedentarized and turning increasingly to cultivation. Fish are an additional important resource with a production of 24000 tonnes in 1987. Forests occupy 19 per cent of the land and produce 21 million $\mathbf{m}^{\mathbf{3}}$ of timber per year. Rangelands occupy 24 per cent and desert 51 per cent of the total land area. Cropped land accounts, according to one source, for only 6 per cent of the national land area, although other sources quote much larger cultivated areas. The 6 per cent figure is almost 
certainly an underestimate, since large areas have recently been cleared for cultivation with machinery provided by the Arab Fund for Economic and Social Development and traditionally cropped areas have expanded greatly in response to recent droughts.

The mainstay of agriculture is cotton, a crop that was introduced into Sudan during the Meroitic period. Long staple varieties of Sudanese cotton are world-renowned. Total cotton production was 400000 tonnes in 1988. Other major crops include sorghum, known locally as 'dura' (4.6 million tonnes), sugar cane (4.5. million tonnes), millet (550 000 tonnes), groundnuts (530 000 tonnes) and cassava (65 000 tonnes), wheat, rice, dates, kenaf and vegetables. Gum arabic is still an important commodity, the production of which rises in drought years as more is gathered to provide supplementary income. Processing of these primary products is a major, if not the essential, industrial activity: 472000 tonnes of sugar, 340000 tonnes of flour and 1.7 thousand million cigarettes were produced in 1987.

Sudan also manufactures 200000 tonnes of cement, 12000 tonnes of plastic ware and 2500 tonnes of perfumes every year. The oil refinery at Port Sudan processes 7.4 million barrels per annum and there is the capacity to produce $\mathbf{1}$ billion $\mathbf{k w}$ of electricity. The main products of mining are salt (40 000 tonnes), chromite (20 000 tonnes), gypsum (7 000 tonnes); gold, mica, manganese and asbestos. The main exports are cotton, gum arabic and sesame.

The road network remains inadequate and, with only $10500 \mathrm{~km}$ of maintained roads, represents a major handicap to development: even this limited capacity is often damaged and impassable during the rainy season. The railways, in spite of their limitations, remain the best means of transportation: they radiate from a hub at Khartoum to Wadi Halfa, Port Sudan, Er Roseires and Nyala. Steamer services run from Kosti to Juba on the southern stretches of the Nile, and from Karima to Dongola in the north, but both are affected by water levels. Sudan Airways, the national airline, has domestic flights to all provinces in addition to its international lines but has continuing difficulty in meeting its schedules. 
Tourism is a potential but largely undeveloped asset. All tastes, from scuba diving on coral reefs in the Red Sea, big game hunting and wiewing, and the archaeological sites along the Nile, could be accommodated. Many areas, such as the Jebel Marra plateau, have outstanding natural scenery. The several National Parks and Reserves include Tokar, Rahad and Dinder along the Ethiopian border; Mbarinzunga, Nimule and the Southern National Park in Equatoria; and Sabaluka close to the sixth cataract and only a half-day trip from Khartoum. New facilities are under construction, especially at Shendi and at several resorts, including Suakin, El Geig, Arousa and Sanganeb on the coast, in an effort to capitalize on the tourist potential.

\section{BIBLIOGRAPHY}

Barbour K.M - 1961. The Republic of the Sudan. London, Athlone.

Berry L., Whiteman A.J. - 1968. The Nile in the Sudan. Geog. J., 134:1-37.

CENTRE OF AFRICAN STUDIES. 1981. Post-independence Sudan. Edinburgh, University Centre of African Studies.

Craig G.M. - 1991. The agriculture of the Sudan. Oxford University Press.

Davies H.R.J. - 1962. Economic and social geography of the Sudan between the White and Blue Niles. Unpublished, B. Litt. thesis/ University of Oxford.

Davies H.R.J. - ed. - 1985. Natural resources and rural development in arid lands: case studies from Sudan. Tokyo, United Nations University. 1985.

FAO - Annuaire Production et Annuaire commerce. Rome, FAO.

Grove A.T. - 1978. Geographical introduction to the Sahel. Géographical J., 144 : 407415 .

Grove A.T. - 1985. The arid environment. In: WICKENS (G.E.), GODDIN (J.R.), FIELD (D.V.) - 1985. Plants for arid lands. London, Allen and Unwin. P. 9-18.

Hurst H.E. , PHILLIPS - The Nile basin. Cairo, Gov. Printing Press, 1931-52.

Lebon J.H.G. - 1965. Land use in Sudan. The world land use survey, Bude, Geographical Publ. xiii - 191 p. (Monograph n\%). 
Lebon J.H.G., Robertson V.C. - 1961. The Jebel Marra, Darfur and its region. Geographical J., $127: 30-49$.

LRDC - 1985. Full bibliography of Sudan. Tradis.

MAFNR (Ministry for Agriculture, Forestry and Natural Resources) - Food investment strategy. 1977-1985. Kharloum, MAFNR.

MFE (Ministry of Finance and Economics) - 1956-60. Economic survey. Khartoum, MFE.

MFE (Ministry of Finance and Economics) - 1961. The ten year plan of economic and social development, 1961/2-1970/1. Khartoum, MFE.

MNP (Ministry of National Planning) - 1977. The six year plan of economic and social development, 1977/8-1982/3. 2 vol. Khartoum, MNP.

Newbold D. - 1924. A desert odyssey of a thousand miles. Sudan Notes Rec., $7: 43-92$.

Olivier J. - 1968. Problems of the arid lands. The example of the Sudan. In: EMBLETON (C.), ed.- Land use and resources. Studies in applied geography, London, Institute of British Geographers. 219-239. (Special publication n`1).

Robinson W.I. - 1987. A review of agricultural studies of Sudan. Bangor, UK, Universily College of North Wales. Centre for Arid Zone Studies.

Tothill J.D. - 1918. Agriculture in the Sudan. London, Oxford University Press.

Tully D. - 1988. Culture and context in Sudan. State University of New York Press.

UNIDO (United Nations Industrial Development Organization) - 1983, The Democratis Republic of the Sudan. Khartoum, UNIDO (Industrial Development Review Series).

WORLD BANK - 1979. Sudan: Agricultural sector survey. Main report and Annexes.

Zahlan A.B. , ed.- 1984. Agricultural bibliography of Sudan, 1974-1983. London, Ithaca.

Zahlan A.B., Magar W.Y., ed. - 1986. The agricultural sector of Sudan. Policy and system studies. London, Ithaca Press. 
Phytogeography and botany. Darag A., Lamarque Georges. 1993. In : Livestock production and sahelian rangelands potential: Republic of Sudan = Élevage et potentialités pastorales sahéliennes : République du Soudan. Darag A., Lamarque Georges. CIRAD-IEMVT - FRA. Wageningen : CTACIRAD-IEMVT, 2-4. ISBN 2-87614-088-8

\section{PHYTOGEOGRAPHY AND \\ A. DARAG BOTANY}

Vegetation formations in the Sudan are principally a function of the rainfall gradient (and hence of latitude, from the deser in the north to the humid zones of the south. Two additional factors, however, have an influence on the vegetation.

The first is the effect of altitude. The major hill masses cause more rain to fall than would be normally expected for a given latitude. Temperatures are also lower at altitude and further assist in reducing evaporative stress. Some species, notably Themeda triandra of the grasses and Orea africana among woody plants, only occur at altitude. Steep gradients cause a concentration of water along valleys. where woody vegetetion may develop even along the desert edge, or close to rocky outcrops and run-on areas totally devoid of any vegetation. At the higher altitudes there are some perennial grasslands.

Soil texture, through its influence on moisture availability, is the second major factor affecting vegetative composition. Water is more readily available to plants on sandy than on clay soils. Plants that habitually grow on sandy soils have root networks that penetrate deeper and extend over wider areas than do plants of clay soils. The gum arabic tree. Acacia senegal, usually has roots longer than 20 metres and the root system of Panicurn furgidum, a grass of arid sandy areas, is very well developed. Species-richness is normally greater on sand than on clay soils and the use of soil water is more effective. Dominant species on clays are less dependent on the climate than those on sand and their active growth phase is shorler. Woody species are also more important on fine-textured clays than on coarser sands but they extend less far north than do those on sands. A similar phenomen is seen with regard to cultivation, which is practised on sands where rainfall is as low as $350 \mathrm{~mm}$ but rainted cropping does not go north of the $400 \mathrm{~mm}$ isohyet on the Nile clays.

\section{THE VEGETATION OF THE SUDAN}

The classification of the Sudan's vegetation by Harrison and Jackson (1958) - which is based on rainfall, altitude and soil type - is still the most detailed one available and remains the most widely used. The boundary between the semi desert and the arid and semi-arid zones is put at $400 \mathrm{~mm}$, to tha north of which fine-leaved Acacia species and the small and hard-leaved species such as Maerua crassifolia and Balanites aegyptiaca dominate. South of the $400 \mathrm{~mm}$ line it is the large-

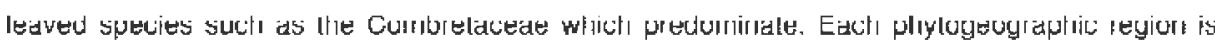
further divided on the basis of major soil types and as a function of altitude.

\section{Desert}

Vegetation is largely absent in the deser with the exception of some oases in fossil walleys, where the Date Palm Phoenix dactylifera is the dominent species. Although many of the oases are gradualy being covered by sand there are some surviving remnants, yet further endangered by the recent droughts, of riverine vegetation including Acacia raddiana and $A$. tortilis. The rare and unpredictable rainfall occasionaly allows the growth of some small grasses, including Aristida papposa, A. pumosa and Triraphis pumilio, as well as a few short-cycle dicotyledons.

In Northern Darlur. following some as yet imperlectly understood combinations of rainfall and temperature, an ephemeral vegetation type, known as "gizu", appoars sporadically (Wilson, 1979). The principal plants of the "gizu" are Indigofera bracteolata. I. arenaria and Neurada procumbens: in addition there are some Zygophylaceae (including Tributus tongipetalus and Fagonia cretica), Crotalaria thebaica and some Aristida species. Formations identical to the "gizu" are also found in the south of the Libyan desert where. as in Sudan. they result from the influence of the Mediterranean climate and combinations of rain and the cool humid air masses moving southwards. The "gizu" is an excellent feed resource, especially for camels, and nomadic tribes from Sudan and Chad travel long distances in search of it. The plants of the formation all contain large quantities of mossture and animals are able to feed on it, sometimes for months on end, without the need to drink. In a good "gizu" year many thousands of animals flock to and produce in areas that are otherwise devord of life. It is also an invaluable element in the long distance caravan trade. This spectacular vegetatwe tormation has always impressed travellers and explorers, many of whom really credited it with too much importance, as its appearance is always irregular and limited in time and space. The "gizu" is not found in Kordofan except occasionally in very small areas between Jebel Tageru and Jebel El Ein, in proximity to the Aristida and Panicum grasslands. 


\section{Semi-desert}

Five formations have been described (Harrison and Jackson, 1958), two of which are grasslands related to soil type and three being scrubs related to geographical position.

\section{Semi-desert grassland on clay}

These grasslands are found in a triangle bounded on the south by a line from Ed Dueim to Kassala, by the line Na'aima-Abu Deleig, and by the Atbara River: they are most usually known as the Butana. The woody species, mainly Acacia mellifera and A. nubica, are found only in shallow valleys and slight depressions. The main field layer species are Schoenefeldia gracilis, Sehima ischaemoides, Aristida spp. and lpomoea spp. This very flat area is only used during the rainy season.

\section{Semi-desert grassland on sand}

This formation is actually a shrub-grassland which is more or less continuous from Darfur to the Nile. The field layer is mainly composed of Aristida spp. (especially A. plumosa), Panicum turgidum, Blepharis linarifolia, Trianthema pentandra, some Cyperaceae and Eragrostis tremula. The most common shrubs are Acacia raddiana, Leptadenia pyrotechnica, Boscia senegalensis and Acacia mellifera. There are few perennial water sources and its main season of use and principally by camels and goats, is during the wet season.

\section{Acacia tortilis and Maerua crassifolia scrub}

Found on both sides of the Nile, this formation occurs on various soil types in a transition area between the semi-desert clays and the desert proper. Principal shrubs and small trees, in addition to the classificatory ones, include Leptadenia pyrotechnica, Acacia mellifera, Capparis decidua, Balanites aegyptiaca and Salvadora persica. Aristida is the dominant grass genus, with Schoenefeldia gracilis on clays. Most of this type of vegetation is concentrated in shallow depressions.

\section{Acacia mellifera and Commiphora scrub}

This formation is discontinuous and occupies the less sandy and more variable areas in the west of Sudan. In addition to the nominate species there are Maerua crassifolia and Boscia senegalensis among the shrubs and Schoenefeldia gracilis, Aristida plumosa and Panicum turgidum in the field layer. Stony soils are characterized by Lasiurus hirtus, Tetrapogon spathaceus and Chrysopogon aucheri.

\section{Acacia glaucophylla and Acacia etbaica scrub}

Found only on the eastern fringe of the semi-desert, this very distinctive formation occurs on the slopes of the Red Sea Hills. It is influenced to a considerable extent by the presence of the nearby Ethiopian highlands. In addition to the type species, Acacia tortilis and Moringa aptera are found, with Phoenix reclinata and several Euphorbia in the numerous valleys.

\section{Low-rainfall savanna}

Six vegetation communities occur north of $12^{\circ} \mathrm{N}$ but two are principally influenced by altitude and will be dealt with later. The first two of the remaining four units are on clay to the east of the country, the last two on sand in the west.

\section{Acacia mellifera grassland on cracking clays}

This formation is found on the extensive clay plains in a rainfall area of between $400 \mathrm{~mm}$ and 570 $\mathrm{mm}$ per year. Acacia mellifera is accompanied by Cadaba glandulosa, C. rotundifolia and Dicrostachys glomerata. The grasses include Cymbopogon nervatus, Sorghum purpurosericeum Dichrostachys glomerata, Schoenefeldia gracilis, Setaria verticillata and Hyparrhenia pseudocymbaria 


\section{Acacia seyal/Balanites aegyptiaca savanna}

Located to the south of the preceding formation these savannas are in a slightly better rainfall area. The two principal species are found with other acacias, including $A$. mellifera, $A$ campylacantha and $A$. drepanolobium. The field layer comprises various grasses, often fairly tall, and includes Beckeropsis uniseta, Rottboellia exaltata, Ischaemum sp., Brachiaria obtusifolia Pennisetum ramosum and Setaria incrassata. Cymbogon nervatus, Rhyncosia memnonia and Heteropogon contortus are also found in this formation.

\section{Acacia senegal savanna}

The gum belt occupies the sandy plateaux and the dunes of red sand. The woody layer is quite varied and representative of a typical sahelian habitat. Acacia senegal, A. raddiana and Acacia nubica occupy the dunes and the interdune hollows. Degraded areas are invaded by Leptadenia pyrotechnica, Maerua crassifolia, Adansonia digitata and Calotropis procera. The field layer, composed of Aristida species (especially A. pallida and A. stipoides), Blepharis linariifolia and Crotalaria microphylla is gradually tranformed to a simple Cenchrus biflorusiEragrostis tremula pasture under the influence of grazing. These areas are grazed during the rains by cattle and then during the dry season by the animals of the northern pastoral tribes. Cultivation in this zone is expanding and occupying more and more of the area.

\section{Combretum savannas}

In areas where rainfall exceeds $400 \mathrm{~mm}$, between $11^{\circ}$ and $13^{\circ} \mathrm{N}$, this formation is predominant. Where not been subject to heavy cultivation there is a considerable cover of woody vegetation, including Adansonia digitata, Acacia senegal, A. nubica and Boscia senegalensis. Among taller broad-leaved trees are Combretum glutinosum. Dalbergia melanoxylon, Albizzia sericocephala, Terminalia laxiflora, T. brownii and Guiera senegalensis. The field layer on sand includes Cenchrus biflorus, Eragrostis tremula and Aristida pallida. Capped areas and wetter soils have a field layer with Brachiaria xantholeuca, Zornia glochidiata, Andropogon gayanus and Monechma hispidum. Bare over-grazed soils are subject to severe erosion and are invaded by Zornia glochidiata and Cassia tora. This is an area that is simultaneously subject to very heavy grazing pressure - from both sedentary herds and commercial herds on their way to market - and to intense cultivation. The installation of water points everywhere has resulted in year-round use by all kinds of domestic stock.

\section{Formations at altitude}

Three formations are influenced by altitude to varying extents, although Harrison and Jackson (1958) classed the first two of them as semi-arid formations on clay. They are, however, clearly separable from the great clay plains of the Nile basin by their lack of monotony, more varied relief and different soil types.

\section{Acacia mellifera and Commiphora africana on hill soils}

This savanna formation occurs on the hills to the north of Jebel Marra and along its eastern slopes. Rainfall is low, about 300-500 mm per year, but vegetation is more abundant than in the arid zone and the husbandry system is not so nomadic. The commonest shrubs, occasionally in dense stands, are Acacia mellifera, Commiphora africana and Boscia senegalensis. Grasses include Schoenefeldia gracilis, Aristida mutabilis, Brachiaria lata, Pennisetum pedicellatum and Setaria pallidefusca: most of these are of excellent nutritional value.

\section{Anogeissus leiocarpus/Combretum hartmannium savanna}

This formation is found on the eastern subhumid hills which form the frontier area with Ethiopia. Rainfall is usually in excess of $800 \mathrm{~mm}$ per year. The soils are shallow, but fertile if formed on basalt, and the woody cover is sometimes quite dense. Woody species, in addition to those named in the formation title, include Acacia seyal. Balanites aegyptiaca and Sterculia setigera. The field layer is largely of Hyparrhenia (especially H. pseudocymbaria), Andropogon gayanus, Schoenefeldia gracilis and Setaria incrassata. Water is in plentiful supply at shallow depths and these pastures are an important dry season feed resource. The Dinder National Park occupies a large proportion of this formation. 


\section{Hill catena}

Jebel Marra and its south-eastern extensions receive good rainfall and have a well developed surface and subsurface water network. They are ideal areas for livestock productivity and only a minimum of seasonal movement is required. The woody vegetation includes Boswellia papyrifera, Combretum hartmannium, Sterculia setigera, Sclerocarya birrea, Adansonia digitata, Acacia nubica, Stereospermum kunthianum, Dicrostachys glomerata and Adenium honghel. Hyparrhenia spp., Beckeropsis nubica, Andropogon gayanus, Cymbopogon nervatus, Pennisetum pedicellatum and Schoenefeldia gracilis are among the major grass species. The complex floristic composition results from the varied environment including the substrate of volcanic or Basement Complex origin and the changes that occur with altitude. The numerous valleys add another dimension to the vegetation of this area: Acacia albida, A. sieberiana, Ficus spp., Tamarindus indica, Cordia abyssinica, Celtis integrifolia and Ziziphus mucronata are the common trees while Cynodon dactylon, Chloris pilosa and Sorghum lanceolatum are conspicuous in the field layer.

\section{Phytoecological classification}

Some convergence in the descriptions of the vegetation communities that have just been described is evident. The overall environment has more influence on the vegetative composition than the simple factor of rainfall. The pseudo-steppes on the sandy soils and the Acacia senegal savanna thus have many components in common. The major differences occur on the different dune types: on recent dunes the pioneer species are Leptadenia pyrotechnica and Panicum turgidum, these being quickly succeeded by Aristida pallida, $A$. plumosa and $A$. funiculata; on older worn dunes Acacia senegal and $A$. raddiana occupy the summits. Balanites aegyptiaca is found on deeper clays, Acacia nubica in the loamy hollows and Acacia mellifera on shallow clays with the Capparidaceae (Maerua crassifolia, Cadaba glandulosa and Capparis decidua) being ubiquitous.

In a similar manner several species of the Sudan savanna, including Salvadora persica, the Combretaceae and the Tiliaceae, and even Strychnos inocua, are present on the edges of rocky areas in the Sahel zone. Here, also, the valleys are occupied by a more hydrophilous vegetation than the surrounding areas.

\section{Geographical distribution}

There is a tendency towards homogeneity in the vegetative formations independently of the climatic zones and, for example, trees such as Balanites aegyptiaca or Acacia mellifera can be locally dominant from the north to the south of the dry savanna area. The distribution of woody species in Kordofan illustrates this clearly (Table 1) and shows that many of them occur over a wide geographical area. Some environments are especially varied but the scale used for the map of necessity leads to some simplification in presentation and to a reduction in the number of communities classed. At the smallest scale it is usual to name communities after the so-called dominant and commonest species but which in themselves indicate only vaguely the type of environment in which they occur: at larger scales these plants are replaced in the community descriptions by species that are more characteristic of the environment.

Vegetation communities are usually complex. In 13 sample areas in the "Acacia tortilis/Maerua crassifolia desert scrub" the nominate species were only found in seven (Baumer, 1958). Areas with most woody vegetation were composed of Acacia nubica, A. raddiana, Balanites aegyptiaca and Ziziphus spinachristi. The field layer is dominated by Tragus berteronianus but Eragrostis cilianensis, Schoenefeldia gracilis, six species of Aristida, Enneapogon brachystachyus, Heliotropium strigosum and Boehravia repens are also frequent species.

Other samples from Acacia senegal savanna showed the common occurrence of Combretum glutinosum and Commiphora africana with 10 other less frequent species. At most sites some 10 grasses are found, the commonest being Aristida mutabilis.

Samples in 23 subdesert valleys showed the regular and widespread occurrence of about 30 plant species, including seven Acacia, Cyperus conglomeratus, Tephrosia nubica, Cymbopogon 
proximus, C. nervatus, Chrozophora brocchiana, Indigotera semitrijuga. Aristida mutabilis, $A$. pallida and $A$. funiculata, all of which are generally only found far to the south. This association, which usually also includes Panicum turgidum and Neurada procumbens on sandy-loam and gravelly soils, has been described previously (Queval, 1958).

Man-made degradation is leading to a certain uniformity in vegetation communities. The formation of Tephrosia nubica/Aristida funiculata, for example, is being transformed in areas where rainfall exceeds $500 \mathrm{~mm}$ per year to an open savanna grassland of Cenchrus biflorus and Eragrostis tremula which is similar to the long-term fallows of the area in which only a few Adansonia digitata and Acacia albida trees remain standing. The increasing appearance of species such as Acacia nubica, Calotropis procera, Cenchrus biflorus and some Cassia species is usually consequent on continuous overgrazing: it is well-known, for example, that the germination of Blepharis linariifolia is greatly assisted by the partial digestion process in the ruminant stomach and the subsequent evacuation in the faeces. Other examples of plants that appear when competition for plant feed resources and other requirements is reduced due to overgrazing and that are not there in response to natural conditions, are Tribulus terrestris, Trianthema crystallina, Zygophyllum simplex and Z. coccineum. 
Table 1 -The ecological distribution of woody species in Kordofan

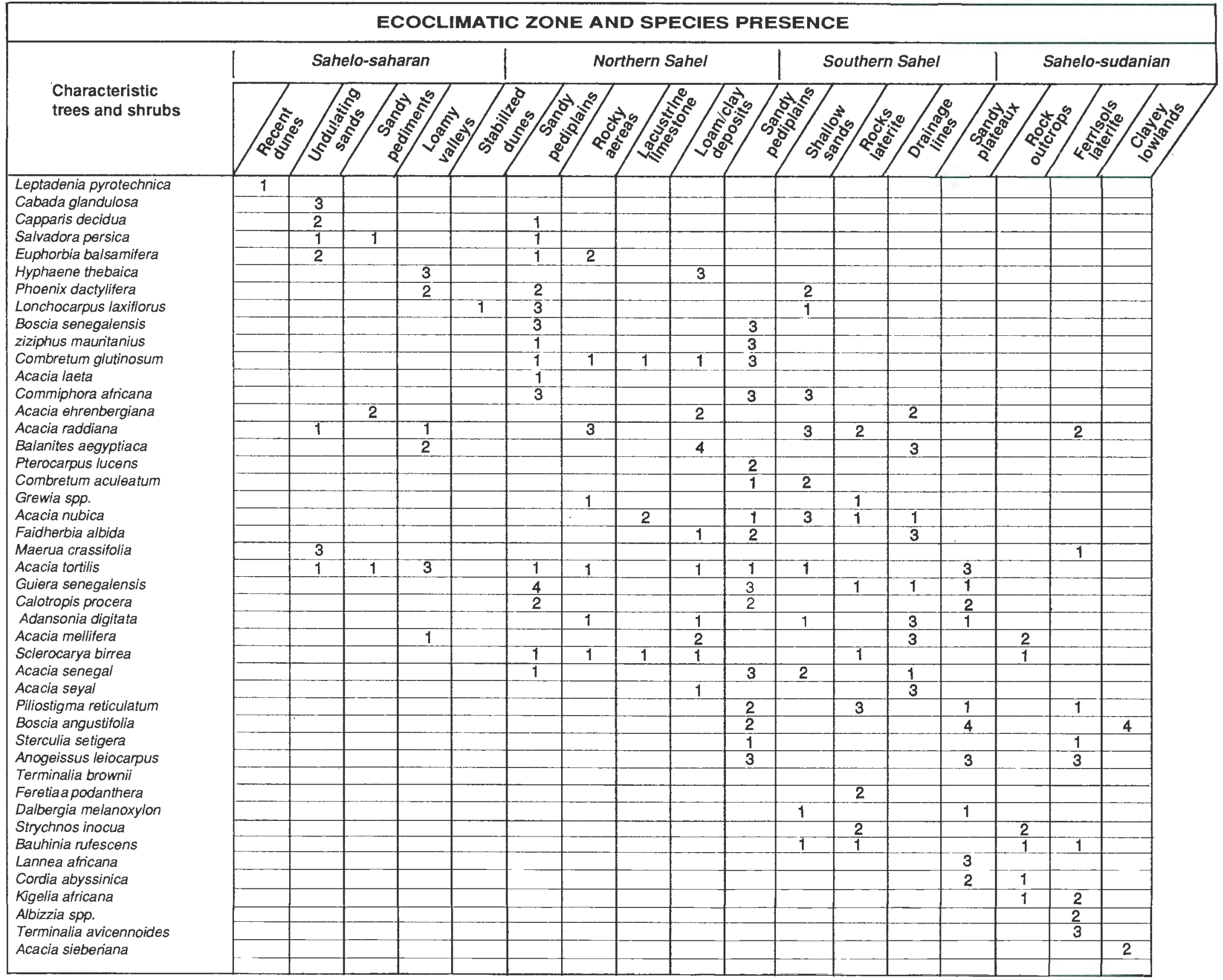

Key : 1 = sparse occurence; 2 = local occurence; 3 = frequent; 4 = very frequent. ( source.: Michel Baumer, pers. comm.) 


\section{Species composition and physiognomy}

Vegetation community descriptions can be expressed in various ways, depending on the way the information has been collected and the type of output desired. Some of the information available for the vegetation of the Sudan provides an opportunity to look at complementary classifications. This is the case for the complex associations of Jebel Marra and its southwestern extensions (Table 2), which have been described earlier in this section as the Hill Catena. The first description is botanical in concept and attempts to differentiate among characteristic local vegetation communities (it is important here to note the importance of Anogeissus leiocarpus - which is not even mentioned by Harrison and Jackson (1958) - and of Acacia mellifera on less favourable soils, whether these are of volcanic or Precambrian origin).

\section{Table 2a - Vegetation units in the Jebel Marra area}

\begin{tabular}{|c|c|c|c|}
\hline Location & Soll type & Vegetation units & , \\
\hline Jebel Marra massif & Volcanic formation & Upland grasslands and meadows & \\
\hline \multirow[t]{2}{*}{ Jebel Marra stopes } & Eastern volcanics & Acacia mellifera shrubland & \\
\hline & Ash piedmont & $\begin{array}{l}\text { Combretum glutinosum and Terminalia } \\
\text { laxiflora or Acacia albida open } \\
\text { savanna }\end{array}$ & \\
\hline Major valleys & Alluvial soils & $\begin{array}{l}\text { Acacia albida and Balanites } \\
\text { aegyptlaca riverine woodlands }\end{array}$ & \\
\hline Western hills & Basement complex & $\begin{array}{l}\text { Anogeissus leiocarpus and Boswellia } \\
\text { papyrifera }\end{array}$ & \\
\hline Lower slopes & Basement complex & $\begin{array}{l}\text { Anogeissus leiocarpus savannas or } \\
\text { Acacia seyal and Anogeissus } \\
\text { leiocarpus mosaic }\end{array}$ & \\
\hline \multirow[t]{3}{*}{ Drier areas } & Basement complex & $\begin{array}{l}\text { Acacia mellifera and Anogeissus } \\
\text { lejocarpus or Acacia mellifera } \\
\text { savannas }\end{array}$ & . \\
\hline & Indurated soîls & $\begin{array}{l}\text { Acacia mellifera and Commiphora } \\
\text { africana }\end{array}$ & \\
\hline & Aeolian sands & $\begin{array}{l}\text { Acacia senegal and Combretum } \\
\text { glutinosum }\end{array}$ & \\
\hline \multirow[t]{2}{*}{ Western plateau } & Clay soils & $\begin{array}{l}\text { Acacia seyal and Balanites } \\
\text { aegyptiaca }\end{array}$ & \\
\hline & Sandstone & $\begin{array}{l}\text { Combrefum glutinosum and Guiera } \\
\text { senegalensis }\end{array}$ & \\
\hline
\end{tabular}

Source: Wickens 1976

\section{Table 2b - Environmental units in Darfur}

\begin{tabular}{|c|c|c|}
\hline $\begin{array}{l}\text { Topography and } \\
\text { geomorphology }\end{array}$ & Soll type & Vegetation \\
\hline $\begin{array}{l}\text { Volcanic steep mountain } \\
\text { cover }\end{array}$ & Deep dark soils & Open woody and medium grass \\
\hline Basement hills & Shallow grey or pink & $\begin{array}{l}\text { Dense woody cover in the southern part, } \\
\text { scattered Acacla and Commiphora in the } \\
\text { north }\end{array}$ \\
\hline Jebbel Mara slopes & $\begin{array}{l}\text { Volcanic soils with } \\
\text { outcrops and stones }\end{array}$ & Dense vegetation \\
\hline Lower slopes & $\begin{array}{l}\text { Basement complex with } \\
\text { red soils }\end{array}$ & $\begin{array}{l}\text { Dense woody cover; Acacia } \\
\text { woodland and bush associations } \\
\text { with Acacia mellifera }\end{array}$ \\
\hline Valleys & $\begin{array}{l}\text { Dark brown soils and } \\
\text { black alluviums }\end{array}$ & $\begin{array}{l}\text { Thorn thickets or medium woody } \\
\text { and tall grass }\end{array}$ \\
\hline Valleys (southern) & Black and grey alluviums & $\begin{array}{l}\text { Riverine grassland, medium } \\
\text { cover of Acacia, Combretum, } \\
\text { Balanites and Acacia seyal } \\
\text { thickets }\end{array}$ \\
\hline Drier areas, Basement & $\begin{array}{l}\text { Pink and red soils, } \\
\text { sometimes eroded }\end{array}$ & $\begin{array}{l}\text { Sparse grassland and scattered } \\
\text { to dense Acacia and Commiphora } \\
\text { cover }\end{array}$ \\
\hline Western plains & Black and grey clays & $\begin{array}{l}\text { Tall grassland with Acacia, } \\
\text { Balanites trees and thorn } \\
\text { thickets }\end{array}$ \\
\hline
\end{tabular}

Source: Hunting Technical service 1968 
The most detailed descriptions are those relating to the higher altitudes on volcanic soils. where five clearly differentiated types are found. In the same work all the valley communities are classed as a single unity.

In the second type of description the environment is defined on the basis of aerial photographs and more emphasis is placed on cover density. The whole of the volcanic mountainous area appears as an area that is well covered with grass with rather dense woody vegetation on the slopes but very open on the summits. The valleys are classified as those on the northern slopes, which are mainly of Acacia, and the more variable ones of the southern slopes. The lower hills of the Basement Complex appear as fairly uniform savannas of Acacia and Commiphora, except close to Jebel Marra, but with some differences related to latitude.

A comparison of these two types of description emphasises the need to take into account local influences such as the underlying geology, type and colour of soil, topographic position, relief, and the steepness of the slopes. The factors mentioned are also closely related to land use and to the 
nutritional value of the feed resources. This information is essential if a simple description that only takes into account climatic factors and botanical composition is to be modified and made useful in the estimation of its pastoral value. The ecological description is also a permanent and stable factor that is independent of climatic fluctuation and changes in the vegetation.

The value of an ecological description can be shown by a study of the Acacia mellifera/Schoenefeldia gracilis formation on fine structured soils in the Sahelian and SudanoSahelian zones. This formation, in the north, is found in clayey depressions, in which it is very dense and difficult to penetrate and where it is surrounded by Acacia nubica. In the south it is found, for example, on the foot slopes of the Nuba Mountains in association with a variety of woody species including Commiphora africana, Combretum aculeatum, C. kordofanum, Guiera senegalensis and Terminalia brownii and field layer species including Beckeropsis nubica, Cyperus rotundus and Setaria verticillata. A vegetation census in the El Ain Forest Reserve near El Obeid (Baumer, 1968) showed a total of 600 trees and shrubs per hectare of which 160 were Cadaba glandulosa, 160 Grewia granosum, 60 Acacia mellifera, 95 Combretum aculeatum and 80 Dicrostachys glomerata, all rising above a dense field layer of Schoenefeldia gracilis, Cymbopogon gracilis and Aristida adscensionis. This kind of formation is subject to intense use for charcoal making, particularly the Acacia mellifera, and heavy grazing which favours the development of fineleaved grasses such as Eragrostis pilosa, E. tremula, E. ciliaris, Chloris prieurii, C. ciliata and C. gayana. The last stage is now much more in evidence around El Obeid than the original formation. A knowledge of the soil type and the topography, however, provides a better indication of what the land would be capable of than can be gleaned from the current vegetation cover.

\section{The pastoral map}

A pastoral map must indicate the grazing value of the different areas and is therefore neither a vegetation map nor a simple physiographic one. The map takes account of such factors as the livestock production system. Within that system the degree of mobility or sedentarization, the species of animals and their levels of production, the degree of common or complementary use with adjacent areas, and the kind of association that the livestock system has with the cropping system need to be taken into account. A pastoral map is thus also an indicator of land use potential and indicates the likely primary production that can be used by livestock, the area in which it is available, and its ability to withstand grazing. In particular the map should indicate the best grazing areas.

\section{Livestock feed resources}

Certain areas make an important, indeed an essential, contribution to the value of a zone in its role as a pastoral area: these include the valleys and all the areas that have a favourable moisture status. The classifications presented above have mainly taken account of the dominant vegetation types with little consideration for the great variation which is found within these large units and without which most areas would be of little value for pastoral production.

There are several ways of classing an area (Table 3). For part of Kassala Province, for example, it is possible to compare the original classification (Harrison and Jackson, 1958) with two later ones, one (FAO, 1978) of which is also based on vegetation types, the other (Gibb, 1968) on soil units. In the most detailed description of the vegetation, grasslands as such have disappeared from the classification in favour of a description that includes trees and shrubs and a field layer that increases in species richness from north to south. The subdivision of Acacia mellifera on clay soils into two units is an indication that the Acacia seyal/Balanites aegyptiaca formation on clay is not strictly confined to the southerly areas: riverine formations as well as those in slight depressions are also given some importance and the total number of vegetative units is doubled.

The classification based on soils provides 18 different units and demarcates five clay plain types in addition to the drainage lines. The fact that one of these is susceptible to erosion or to capping indicates that moisture status varies and that there are differences in the growth periods of the vegetation. The undulating plains are more varied and for the most part are occupied by Acacia mellifera: they are complemented by alluvial depressions which allow the whole area to be grazed over a longer season. While the vegetation itself is not affected by this classification, the distinction is important for grazing management.

The Atbara River valley is subdivided into a flood plain and the degraded and fragile areas on the lower and upper terraces, which separate the river valley from the clay plains. The subdesert 
pastures to the north include some depressions and drainage lines, the vegetation of cannot be classified as a result solely due to sandy and rocky areas which cover most of it and on the basis of which its value as a feed resource would be much lower.

\section{Table 3 - Environment and vegetation in Kassala Province}

\begin{tabular}{|c|c|c|}
\hline \multicolumn{3}{|c|}{ Source } \\
\hline $\begin{array}{l}\text { Harrison and Jackson } \\
1958\end{array}$ & FAO 1978 & Gibb 1968 \\
\hline $\begin{array}{l}\text { Acacia tortilis-Maerua } \\
\text { crassifolia desert scrub }\end{array}$ & $\begin{array}{l}\text { North-western semi-desert } \\
\text { and bare areas, Acacia } \\
\text { raddiana and A. ehrenbergiana, } \\
\text { Aristida spp. } \\
\text { Semi-desert on sand, } \\
\text { A. raddiana and A. tortilis, } \\
\text { Leptadenia, Maerua crassifolia, } \\
\text { Capparis, Panicum turgidum }\end{array}$ & $\begin{array}{l}\text { Desert pediplain, Aristida spp } \\
\text { Wadi alluvium (grass) } \\
\text { Closed clay plain } \\
\text { Dunes and sandsheets, } \\
\text { Capparis decidua and } \\
\text { A.raddiana } \\
\text { Gash depression } \\
\text { Sand sheets, dunes and } \\
\text { interdunal bare flats }\end{array}$ \\
\hline $\begin{array}{l}\text { Semi-desert grassland } \\
\text { on clay }\end{array}$ & $\begin{array}{l}\text { Semi-desert on clay A, nubica } \\
\text { and A. mellifera, Schoenefeldia, } \\
\text { Blepharis } \\
\text { khasm-el-Girba and Gash schemes } \\
\text { Riverine vegetation, Capparis, } \\
\text { Calotropis, Hyphaene, Acacia spp. }\end{array}$ & $\begin{array}{l}\text { Aggradational north } \\
\text { central clays plain, } \\
\text { grass and herbs } \\
\text { Wadi alluvium } \\
\text { Semi-desert aggradational } \\
\text { clay plain; semi-desert } \\
\text { degradat onal clay plain; } \\
\text { gently undulating degra- } \\
\text { dational clay plains } \\
\text { (Acacia mellifera) }\end{array}$ \\
\hline $\begin{array}{l}\text { Acacia mellifera on } \\
\text { cracking clay, atter- } \\
\text { nating with grass areas }\end{array}$ & $\begin{array}{l}\text { Acacia mellifera } \\
\text { thornland, with Acacia nubica, } \\
\text { Balanites, Cadaba rotundifolia, } \\
\text { Cymbopogon, Sorghum, Sporobalus } \\
\text { helvolus }\end{array}$ & $\begin{array}{l}\text { Aggradational south- } \\
\text { central clay plain } \\
\text { (A. seyal and A. nilotica) } \\
\text { Isolated hills }\end{array}$ \\
\hline & $\begin{array}{l}\text { Acacia savanna (A. seyal, A. } \\
\text { senegal, A. mellifera, A. nubica } \\
\text { Bajanites, Cymbopogon nervatus, } \\
\text { Sorghum spp. Hyparmenia) }\end{array}$ & $\begin{array}{l}\text { Degradational clay plain } \\
\text { (A. mellifera) } \\
\text { Lower and Upper "Kerrib" } \\
\text { (A. seyal, A. raddiana, } \\
\text { A. ehrenbergiana, Capparis, } \\
\text { Calotropis) } \\
\text { Atbara flood plain (Hyphaene, } \\
\text { A. ehrenbergiana, Capparis) }\end{array}$ \\
\hline & & · \\
\hline
\end{tabular}

When mapped at a scale that is useful for pasture management purposes it can be seen that these areas are more complex than would be indicated by a purely botanical description. The valleys in the semi-desert are in fact very useful pasture areas (Baumer, 1968) and include Acacia raddiana and $A$. tortilis in the browse layer and Cymbopogon proximus, Panicum turgidum, Tragus berteronianus, Aerva javanica, Eragrostis cilianensis and Schoenefeldia gracilis in the field layer: in the more sandy valleys Demostachya bipinnata, Aristida spp. Indigofera arenaria, I. hochstetteri, Tephrosia vicioides, Schmidtia pappophonoides and Ischaemum afrum are also found. There are also small depressions with Sorghum sudanense, which can grow as tall as 2 metres on a rainfall of as little as $150 \mathrm{~mm}$, and even though these areas are very small their contribution to livestock nutrition is very important, particularly in view of the fact that this grass is high in salt content and is a favourite animal feed.

\section{A practical pastoral classification}

The classification decided upon for the 1:500 000 map is based to some extent on climatic factors but also includes a large number of those just discussed. The division between the hyper-arid and the arid (or Sahelian stricto sensu) zones falls at about the $200 \mathrm{~mm}$ isohyet. This is not because the vegetative composition changes at this limit but because of the implication that there are small areas of useful pasture to the north of the line whereas south of it there are much larger contiguous areas of good grazing. The other major climatic distinction is put at $350 \mathrm{~mm}$ on sands and $400 \mathrm{~mm}$ on clays because these are the limits of rainfed cultivation as seen on the satellite images. In the western mountainous areas (where geology, topography and substrate are much more important than rainfall) the use of rainfall isohyets has been discarded in favour of a more general description. The small area of the Nuba Mountains included on the map and the wetter hills of the southeast have not been classed separately from the areas around them as they form of continuum with these and are much less influenced by the altitudinal effects than are the mountainous areas in Darfur. To the north of the 12th parallel of latitude seven major grouping have been distinguished: 
D: The desert and the Red Sea Hills. The desert in the strict sense has been restricted to those vast areas where there is no vegetation at all except in the few valleys and at the bases of hills (and these can be seen clearly on the images where it has previously been considered that there was absolutely nothing). Included in the desert are the inhospitable hills in the extreme north-east of the country, again with vegetation only in the valleys, and which are almost totally unused. It needs to be noted, however, that the valley vegetation in the north-east, mainly Acacia glaucophylla and Aristida acutiflora, differs from that in the rest of the desert area.

X: The very arid or Saharo-Sahelian zone. Feed resources are irregularly scattered in the almost totally bare sand and rock desert areas and are almost confined to the more favoured valley sites. The zone is grazed only during the rainy season by camels and small ruminants: these travel long distances, mainly along the wadi beds, from their dry season bases that are perhaps several hundred kilometres to the south. The main woody species are Acacia raddiana and $A$. tortilis with an understorey of Panicum turgidum and Aristida plumosa.

A: The arid or Sahel zone. As for the previous zone, this is essentially a wet season grazing area but is also used by cattle. Areas with capped soils and those shallowly covered with blown sand are the only ones that are devoid of vegetative cover. The whole zone is mainly sandy dunes in various stages of development and with a vegetation that changes from year to year. The main plant species are Acacia senegal, Commiphora africana, Aristida mutabilis and Cenchrus biflorus.

L: The arid clay plains. The growing season is usually shorter than that of the previous zone, and the whole area presents a monotonous uniformity except around its edges. Pastoral use is often opportunistic, without any regular pattern, and adapted to a feed resource that varies greatly from one year to the next. Acacia mellifera, A. nubica, Cymbogon nervatus and Aristida adscensionis are the dominant plant species.

S: The semi-arid or Sudano-Sahelian zone. This is the classic pastoral area in which cattle predominante and where they are often sedentary. There are also some camels which are present more by historical accident than because this is a zone that is favourable to them. Once well-wooded, the zone is now very much degraded with many poor quality grasses in the pastoral areas and on old fallows. The typical woody plants are Combretum and Albizzia with Schoenefeldia gracilis and Eragrostis tremula in the understorey.

C: Semi-arid clay plains. Modern cultivation techniques have turned this semi-arid to subhumid zone into one in which very few grazing areas remain. Rainfall on the southern border is as much as $800 \mathrm{~mm}$ per year. Except for areas on basalt or at higher altitudes the vegetative cover is not as dense as in 'S' and Acacia seyal and Balanites aegyptiaca are associated with Sorghum and Hyparrhenia species.

M: The high altitude zone. This is a major livestock production area where, because of the varied soil types and the numerous valleys, short distance movements prevail. Changes in vegetation are more in response to altitude than to latitude. The most common plants are Anogeissus leiocarpus, Acacia albida, Aristida funiculata and Setaria spp.

Within each of the above zones it is possible to group the various vegetation associations as a function of the major landscape units which are themselves usually identified as having a specific

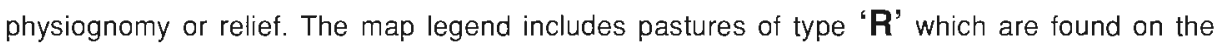




\section{PHYTOGEOGRAPHY AND BOTANY}

\section{(CONTINUED)}

summits, slopes and foothills of the hills and mountains (whether volcanic, Pre-cambrian or of sandstone) and also on the rocky peneplains, stony desert and sometimes on shallow sands. The ' $S$ ' units are on sandy plains and plateaux and here a directional mark indicates the alignment of the dunes. A letter ' $C$ ' in second position indicates fine textured loam or clay soils on flat land or barely distinguishable slopes with compact or capped soils of very poor drainage capacity: the direction of valleys and depressions is indicated by a ' $V$ ' and the major vegetation forms are retained.

The species of vegetation used to characterize the various units, whether they be woody or herbaceous plants, represent a compromise between the dominant plants (which would probably be found in most of the units in the same area) and those that are truly characteristic but not necessarily very frequent, and which may also disappear under the influence of man and his animals. The mapped units reflect the need to distinguish a number of pastoral units at a small scale within a geographically- defined vegetation association: it is necessary, when using the map, not to dissociate the plant species used as indicators from those which are dominant in the same area.

\section{Acknowledgements}

The Editors are grateful to all who helped to make this pastoral map possible, and especially to Michel Baumer who allowed the use of his many personal papers on the Sudan savannas.

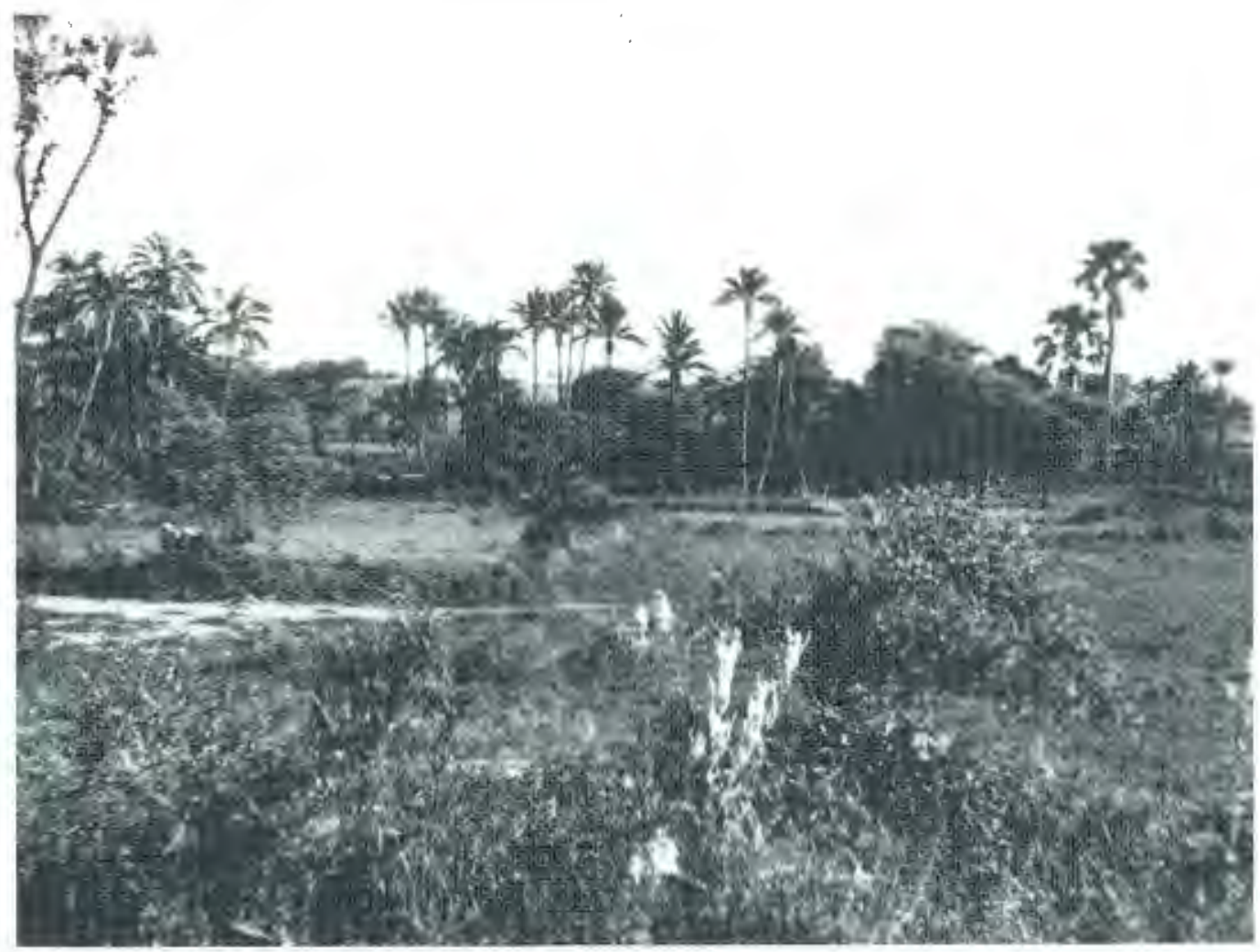

\section{BIBLIOGRAPHY}

1. Ahmed A.A. - 1983. Forest reserves and woodland savanna regeneration on the subSaharan massif of Jebel Marra, Democratic Republic of the Sudan. Vegetatio. $54: 65-78$.

2. Alam El Din I.O. - 1986. A note on vegetation. In: DAVIES (H.R.J.), ed. - Rural development in White Nile Province, Sudan. Tokyo, United Nations University. P. $43-44$.

3. Andrews F.W. - 1948. The vegetation of the Sudan. In: TOTHILL (J.D.), ed. - Agriculture in the Sudan. London, Oxford University Press. P. 32-61.

4. Andrews F.W. - 1950. The flowering plants of the Anglo-Egyptian Sudan. Vol. 1-3, Arbroath, Scotland, T. Buncle.

5. Baumer M. - 1968. Ecologie et aménagement des pâturages au Kordofan. Univ. Montpellier, France, 560 p. 
6. Baumer M. - 1964. The ranges of Dar Meganin, II.Sudan Notes Rec., 44 : 133-147.

7. Bayoumi A.A. - 1974. Forest Bibliography of the Sudan up to 1973. Khartoum, National Council for Research, Agricultural Research Council.

8. Crowfoot G.M. - 1946. Flowering plants of the Northern and Central Sudan. Leominster, UK, Orphans' Printing Press.

9. El Hadidi M.N. - 1976. The riverain flora in Nubia. In: RZOSKA (J.) ed., The Nile Biology of an ancient river. The Hague, Junk Publishers. P. 87-91.

10. Ghabbour S.I. - 1972. Flora of the Nile region at the Dongola Reach, Sudanese Nubia, Revue Zool. Bot. Afr., 85 : 1-29.

11. Halwagy R. - 1961. The vegetation of the semi-desert north-east of Khartoum. Oikos, 12 (1) $: 87-110$.

12. Harrison M.N., Jackson J.K. - 1958. Ecological classification of the vegetation of the Sudan. Khartoum, Forests Department, (Forest Bulletin N2. New Series).

13. Kassas M. - 1956. Landform and plant cover in the Omderman Desert, Sudan. Bull. Soc. Geograph. Egypte, $29: 43-58$.

14. Lampen E. - 1928. A shor account of the Meidob. Sudan Notes Rec., $11: 55-67$.

15. Leonard J. - 1969. Expédition scientifique belge dans le désert de Libye. AfricaTervuren, $15: 101-136$.

16. Miche S. - 1988, Vegetation ecology of the Jebel Marra massif in the semi-arid Sudan. Dissertationes Botanicae, $113: 1-171$.

17. Mubarak M.O. , Bari E.A., Wickens G.E. , Williams A.A.J. - 19B2. The vegetation of the central Sudan. In: WILLIAMS M.A.J., ADAMSON D.A., ed. - A land between two Niles. Rotterdam, Baikema, P. 143-164.

18. Newbold D. , Shaw W.B.K. - 1928. An exploration in the South Libyan desert. Sudan Notes Rec., $11:$ 103-194.

19. Obeid M., Mahmoud A. = 1969. The vegetation of Khartoum Province. Sudan Notes Rec., $50: 134-159$.

20. Quezel P. - 1969. Flore et végétation des plateaux du Darfur Nord-occidental et du Jebel Gourgeil. Dossier 5 de la Recherche Coopérative sur Programme N45. Marseille, Centre National de la Recherche Scientifique.

21. Quezel P. - 1970. A preliminary description of the vegetation in the Sahel region of North Dartur. Sudan Notes Rec., 51 : 119-125.

22. Radwanski S.A., Wickens G.E. - 1967. The ecology of Acacia alibida on mantle soils in Zalingei, Jebel Marra, Sudan. J. appl. Ecol., 4 : 569-579.

23. Shaw W.B.K., Hutchinson J. - 1934. The flora of the Libyan desert. Bull. Misc. Inf. Kew. P. 281-289.

24. Schweinfurth G. - 1867. Enumeration and description of the Acacia species of the Nile Region. Linnaea, $35: 7-9$.

25. Smith J. - 1949. Distribution of tree species in the Sudan in relation to rainfall and soil texture. Khartoum, Ministry of Agriculture. (Sudan Government Ministry of Agriculture Bulletin $N^{\circ} 4$ ).

26. White F. - 1983. The vegetation of Africa. A descriptive memoir to accompany Ph Unesco AETFAT UNSO vegetation map of Africa. Paris, Unesco.

27. Wickens G.E. - 1977. The flora of Jebel Marra (Sudan Republic) and its geographical affinities. Kew Bull. Additional Series V.

28. Wickens G.E. , Collier F.W. - 1971. Some vegetation patterns in the Republic of the Sudan. Geoderma, $6: 43-59$.

29. Wilson R.T. - 1978. The "gizu" : winter grazing in the South Libyan desert. J, arid Environ., $1: 325-342$.

30. Worral G. - 1960. Patchiness in vegetation in the northern Sudan. J. Ecol. 48: 107-115. 


\section{SATELLITE IMAGERY AND}

\section{G. ForgiaRINI G. LAMAROUE CARTOGRAPHY}

\section{Range meps}

This set at a scale of 1: 500,000 is the lagical extension of earlier volumes produced on the West Atrican Sahel between the rantall isohyets of $150 \mathrm{~mm}$ and $600 \mathrm{~mm}$. The 12 sheets in this atlas of the Sudan are complementary to the $\mathbf{3 4}$ already published. It is now possible for sclentists, planners and developers to consult a set of 46 maps on the range production potentia of the whole of the tradtional liwestock production zone, covering more than $2,100,000 \mathrm{~km}^{2}$ extending from the Atlantic Ocean in the west to the Sudanese-Ethiopian frantier in the east.

\section{Scale}

Earlier thernatic maps have been of a wery general tyoe, varyıng in the quality of the information they provided, ohen not covering complete areas, and of varying scales. It is possible to prepare arl uriform comparative presentation only if data are treated equally and are in the same detail for the whole of a particular study.

It was apparent at the outset that mapping the agropastoral zone of the Sudan would require the use of LANDSAT imagery, tor several reasons, but principally because of the vast area

$800,000 \mathbf{~ k m}^{2}$ - to be covered and the lack of an existing set of detailed and up-to-date maps. The scale adopted required enlargement of the false-colour LANDSAT Irnages to a scale of 1: 500000 . This projection is sufficiently close to the basic mapping scale that has been adopted and allows of adequate interpretation and transfer of information. A series of ground-truth exercises showed that such irterpretation and transfer was indeed generally correct.

\section{METHODOLOGY}

\section{Conception of the maps}

The Sudan, as long ago as 1973, was among the pioneering Atrican countries in the use of firstgeneration satellite imagery. Some of the results of that early work have been published (and been made use of in the present work, while others have untortunately not yet seen the light of day. A total of 42 satellite images was used for the maps, of which 32 were in false colour and 10 in black and white, these last being used in order to obtain data for a wery narrow band of country to the south of the project area (seg make up table for delails)

in spite if the large number of LANDSAT images avallable tor the region the chorce of the ones. actually used was limited by the absence of cloud cover and the need for them to fall within a ceraln time spans. Most of the images thus date from the dry season of 1986. This selection has not caused any problems for the inventory that has been done. which includes land use, topography, soil type, geomorphology and vegelalion as the principal criteria. These parameters are replatively stable but can be adapted to take account of any new developments.

\section{Interpretation of the satellite images}

The scale of enlargement was sufficent to allow a relatively accurate interpretation of the boundaries between the various unit. It needs to be stated, however, that some detail is always lost when using satellite imagery as the smallest area that can be identified is a ways of about 0.42 ha (1 acre, 1 feddan) whatever scale of enlargement is used. 
The mapped units did not require major changes when they were transferred to the topographic maps but some formations were occasionally amalgamated for thematic reasons.

The initial interpretation work comprised the identification and the stratification of the major ecological units by tracing them on the map. The main reason for this operation is to reduce the internal variability of the units and to obtain an immediate and high level of uniformity.

The regional inventory thus consists of:

\section{Major natural reglons;}

mountains and inselbergs, the volcanic areas of Darfur and the hilly areas along the Ethiopian frontier, weathered and eroded glacis, sandy plateaux, and dune systems classified by alignment and morphology;

. gently undulating "qoz", clay plains, waterlogged depressions, and permanent and temporary standing water;

the major river systems, including thalwegs, valleys, alluvial terraces and flood plains classed in relation to the origin of the deposited material (sand, clay, loam or volcanic ash);

\section{Regions affected by anthropogenic activity;}

irrigated, mechanized and traditional rainfed agriculture;

. urban areas, roads and lines-of-rail, where these could be identified.

The second operation was designed to establish the relationship between the identified major units and their vegetation. Individual plant species will thus be found on various type of soil, in different geomorphological areas and under several climatic regimes.

Other clearly visible features were used for further subdivision of the major units. These included, in particular, dynamic elements such as signs of degradation through weathering or by overgrazing. The vegetation gradient from north to south, and the effects of orography and aspect, particularly for the Darfur jebels, also assisted in deciding on the subdivision.

\section{Maquettes and final versions}

Twelve maquettes at the scale of the LANDSAT imagery were finally prepared. These draft maps were checked by the cartographers by the use of hand-colouring, this providing the most effective visual method of the accuracy of the work carried out. Modern cartographic methods were not used until the final stages of the mapping.

Following technical verification, the maquettes were transferred, without any problems, to the American ONC topographic base maps. The Lambert-Mercator conical projection with fixed longitudes used for these maps is compatible with those of the French National Geographical 
Institute which was used for the West African Sahel countries. The earlier maps prepared for the Chad-Sudan border area thus match very well with the present ones.

The final phase of map preparation used the latest available technology. The maps were printed in four colours using the BAFCO automated system. The legend was first completed and used as the data base to instruct the software as to the exact nature of each of the 80 formations identified from LANDSAT imagery and used on the maps. Special maquettes were then constructed which carried the designations of the mapping units (DF1, DF2, etc.) and the boundaries of the units which had already been scanned by the system. The colour separations were then produced in black, cyan, magenta and yellow.

\section{Toponymy}

The toponymy was established from the standard British maps that are still most used in the Sudan and which are indeed the only maps available at various scales from $1 ; 500,000$ to $1: 250,000$. The spelling of places and other names used on these maps has largely been retained for the present ones, although there are some minor modifications resulting from recent Sudanese work and from presentations at international fora.

\section{Map legend}

The legend is presented in tabular form to include, from left to right, the mapping units described on the basis of their geomorphology and then the typical woody vegetation and field layer of these units. This basic data is complemented by notes relative to land use and other factors and occasionally by some of the constraints attached to each unit.

\section{Water resources}

Boreholes and wells have been marked on the range maps because these are a major contributor to the pastoral value of an area. Each conventional sign is accompanied by information - provided by the Sudan office of BRGM - on the depth of the bore or well, static water level, salt content, and discharge.

\section{Conclusion}

In addition to making this atlas available to a wide variety of potential users, a whole data base of information essential to a full understanding of Sudanese livestock production has been established. This data base is now available for future up-dating. For example, the state of the pastures can be regularly monitored and the latest changes recorded, on computer diskette. The end result is, in fact, an essential basic tool in the development of a Geographical Information System on livestock production in the Sahel zone of the Sudan.

\section{BIBLIOGRAPHY}

1. Gomarasca M.A., Zllol E. , Tomasoni R., Dessema M. A - 1990. Cartes thematIQUES DÉHIVÉES DES IMAGES SATELLITAIHES SPOT DU NORD DE DARFUr (SOUdAN). REV. PHOTO - INTERPRETATION N 1990 - 5, P. 52 - 55. EDIT. ESKA, PARIS

2. Robinson . W. I - Areview of Agricultural Study of Sudan - 1987. Centre for Arid Zones Studies - University College of North Wales - Bangor - p. $176+$ annex + 1 map 1/5000 000, 2 maps 1/10 000000.

3. N.R.I - Terrain Units Images map of central Sudan. 3 maps 1/ 1000000 colours Chatham, Kent, UK. 


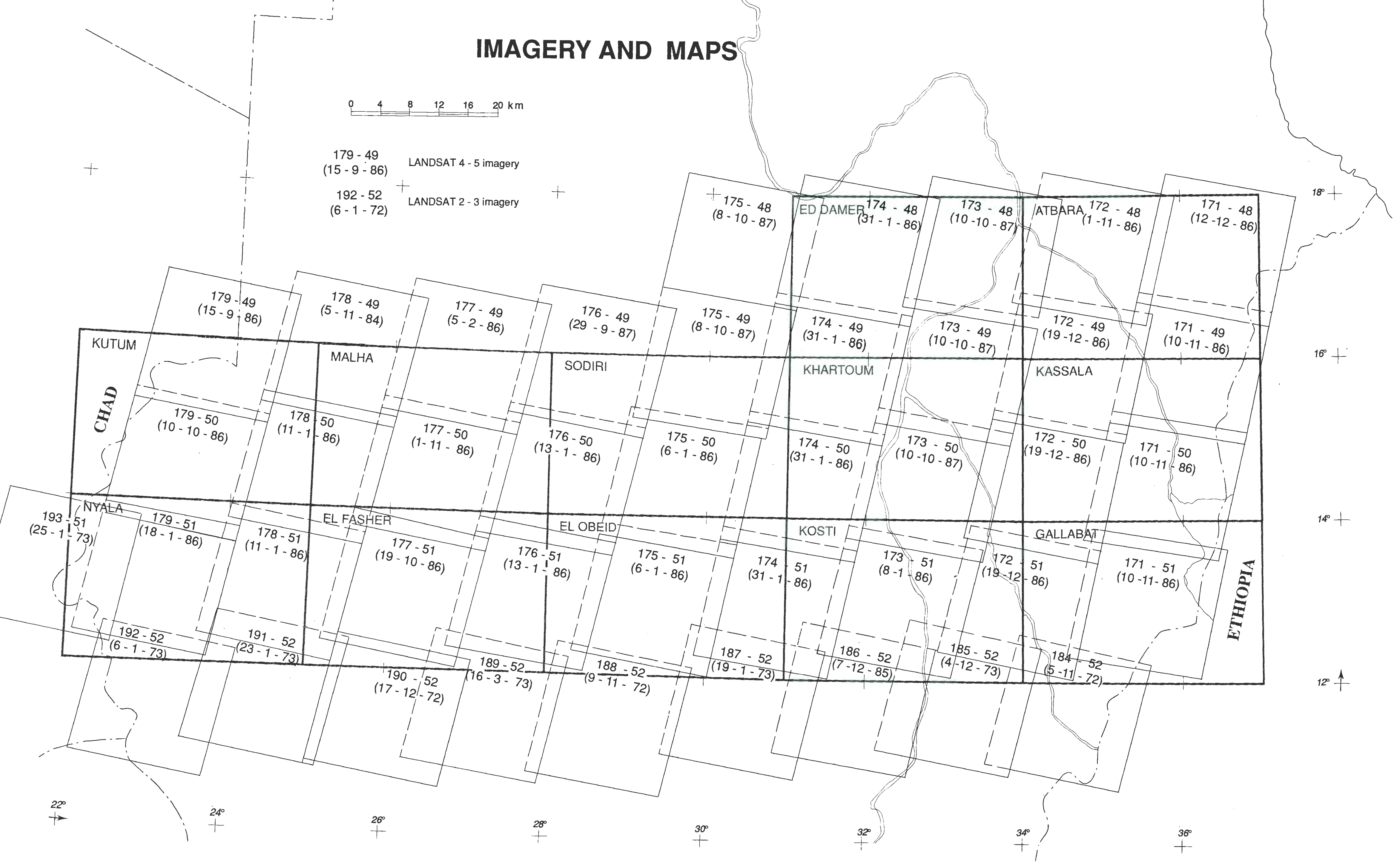


VEGETATION OF SUDAN (1968, Harrison \& Jackson)

(reproduced from : Sudan Survey. Dept. Khartoum 1964)

1/500.000 RANGELAND MAP : LEGEND

\begin{tabular}{|c|c|c|c|c|c|c|c|c|c|c|c|c|c|}
\hline & Units & Physical environment & Plant cover & Characteristic trees & Characteristic grasses & Remarks & & Units & Physical environment & Plant cover & Characteristic trees & Characteristic grasses & Remarks \\
\hline & DR1 & $\begin{array}{l}\text { exposod higher } \\
\text { oranic orks }\end{array}$ & $\begin{array}{l}\text { restricted to steep } \\
\text { dissected siopes }\end{array}$ & 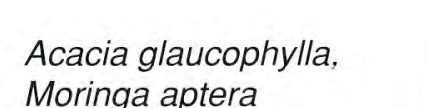 & $\begin{array}{l}\text { Aristida ciliata, } \\
\text { Tetrapocon ospathaceus }\end{array}$ & $\begin{array}{l}\text { Red Sea massits, } \\
\text { no grazinin value }\end{array}$ & & SR1 & granitic mountains & good woody cover & 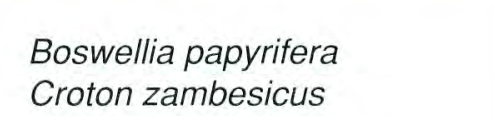 & $\begin{array}{l}\text { Pennisetum pedicellatum } \\
\text { Rhynchosia memonoria }\end{array}$ & $\begin{array}{l}\text { denser woodland on Jubel } \\
\text { Davar. Fewer trees on N Nuta Mountains }\end{array}$ \\
\hline & DR2 & lower hills and insolbergs & $\begin{array}{l}\text { sparse, in easterm } \\
\text { sccio ony }\end{array}$ & $\begin{array}{l}\text { Acacie ettaica } \\
\text { Marum cassitia }\end{array}$ & Arisitid plumosa & widespread rocky unit & & SR2 & $\begin{array}{l}\text { granitic slopes with } \\
\text { sand sheetis }\end{array}$ & $\begin{array}{l}\text { trees along the } \\
\text { draninges }\end{array}$ & $\begin{array}{l}\text { Dichrostatchys glomerata } \\
\text { Euvfhoria spp. }\end{array}$ & 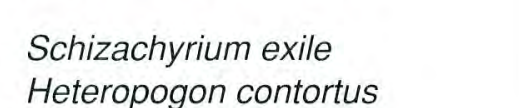 & $\begin{array}{l}\text { many erododd slopes around } \\
\text { Nuba Muontins }\end{array}$ \\
\hline & DR3 & $\begin{array}{l}\text { rocky pediplains and } \\
\text { piemonots and }\end{array}$ & none observed & & & base of rocky terrains & & ss1 & $\begin{array}{l}\text { tlat or undulating } \\
\text { sand plain }\end{array}$ & $\begin{array}{l}\text { good homogeneous } \\
\text { plant cover }\end{array}$ & 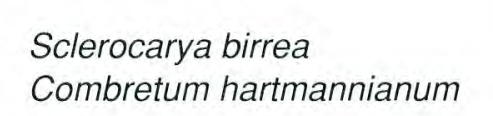 & 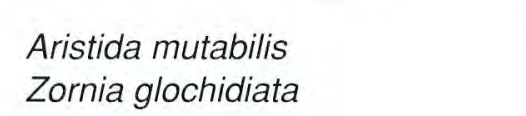 & 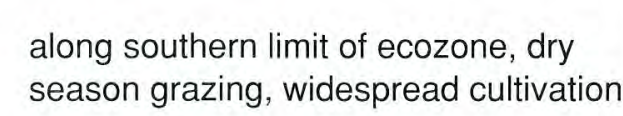 \\
\hline & DR4 & $\begin{array}{l}\text { sand sheet on rocks, } \\
\text { lower slopes }\end{array}$ & $\begin{array}{l}\text { scattered alang } \\
\text { eastern slopes }\end{array}$ & $\begin{array}{l}\text { Salvadora persica } \\
\text { Capporaris decicua }\end{array}$ & Arisitida plumosa & $\begin{array}{l}\text { transition towards the very } \\
\text { arid aras }\end{array}$ & & ss2 & $\begin{array}{l}\text { rolling or hardened } \\
\text { qoz on sandstone }\end{array}$ & trees in depressions & $\begin{array}{l}\text { Termininaliataxitora } \\
\text { Guivera sengalensis }\end{array}$ & 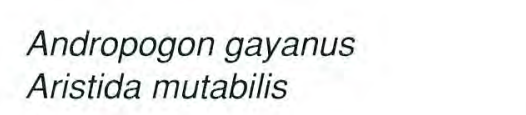 & $\begin{array}{l}\text { high fround with haolian sand, } \\
\text { less sulvivition }\end{array}$ \\
\hline & DS1 & desert sandy plain & none & & & $\begin{array}{l}\text { Western sands. Extensive } \\
\text { grazing ana b brovsing }\end{array}$ & & ss2 & $\begin{array}{l}\text { transverse dunes or } \\
\text { sand monoticles }\end{array}$ & " " " & 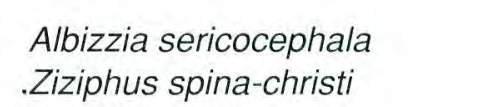 & 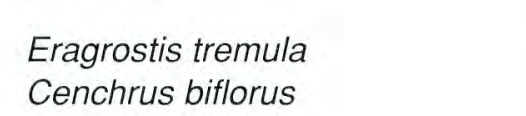 & isolated units, no crops \\
\hline & DS1' & longitudinal sand ridges & none. & & & dunes south of Gilif Jebels & & sc1 & $\begin{array}{l}\text { loanyy sand plains } \\
\text { ontasesment }\end{array}$ & $\begin{array}{l}\text { tair homogeneous } \\
\text { vegetation }\end{array}$ & $\begin{array}{l}\text { Tememinalab ar rowniri } \\
\text { Tamanindus indica }\end{array}$ & $\begin{array}{l}\text { Paricum maximum } \\
\text { Ctenium elegans }\end{array}$ & 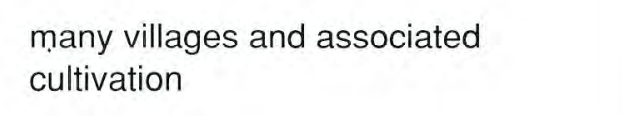 \\
\hline & Dv1 & fossil wide valleys & very sparse & Acacia tortilis & Panicum turgidum & Wadi Muaaddam system & & sc2 & $\begin{array}{l}\text { eroded surfaces usually } \\
\text { on schists }\end{array}$ & $\begin{array}{l}\text { riverine woodlands } \\
\text { and grass slopes }\end{array}$ & $\begin{array}{l}\text { Acacic mellifira } \\
\text { Grewia pannosum }\end{array}$ & 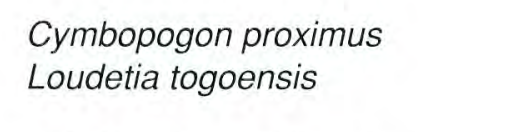 & poor rangeland \\
\hline & Dv2 & $\begin{array}{l}\text { major mountain orainages, } \\
\text { lower vallys }\end{array}$ & medium cover & 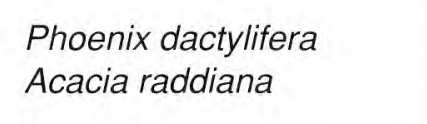 & 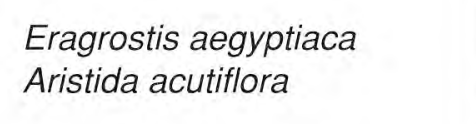 & $\begin{array}{l}\text { easterm traingag lines and } \\
\text { wari botroms }\end{array}$ & & sc3 & $\begin{array}{l}\text { wetc thays sand loams, } \\
\text { terraces ardeperession: }\end{array}$ & $\begin{array}{l}\text { densec cover on } \\
\text { lower ground }\end{array}$ & $\begin{array}{l}\text { Acacic seyal } \\
\text { Cacadaba glandulosa }\end{array}$ & 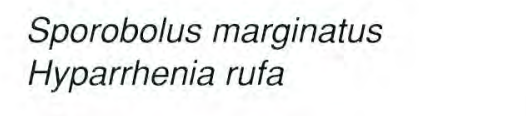 & 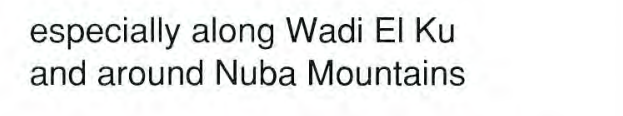 \\
\hline & XR1 & $\begin{array}{l}\text { basement and } \\
\text { sandontsone massits }\end{array}$ & $\begin{array}{l}\text { mostly on southern } \\
\text { part of ecocozone }\end{array}$ & $\begin{array}{l}\text { Comminhora africana } \\
\text { Ziziphus mauntiana }\end{array}$ & $\begin{array}{l}\text { Traguub berterorinanus } \\
\text { Arisidid mutatilisis }\end{array}$ & $\begin{array}{l}\text { Includidg a adicic rocks east of } \\
\text { Wadi EI Milk and Teiga plateau }\end{array}$ & & sc4 & 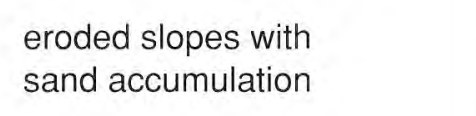 & $\begin{array}{l}\text { trees concentrated } \\
\text { on nininuratad atotom }\end{array}$ & $\begin{array}{l}\text { Acacaia ubica } \\
\text { Acaciam melifer }\end{array}$ & $\begin{array}{l}\text { Digitaria a adscendens } \\
\text { Walthrar indica }\end{array}$ & 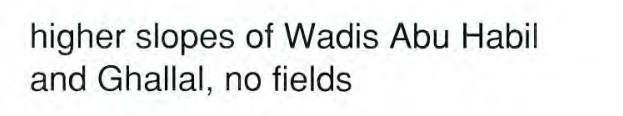 \\
\hline & хR2 & basalitic rocks & $\begin{array}{l}\text { restricted to craters } \\
\text { annd dranage lines }\end{array}$ & $\begin{array}{l}\text { Sitychnos innocua } \\
\text { Capopars decidiala }\end{array}$ & $\begin{array}{l}\text { Aristida plumosa } \\
\text { Latapes sengegansis }\end{array}$ & Meidab and Berti formations & & sv1 & sandylloamy alluvions & dense cover & 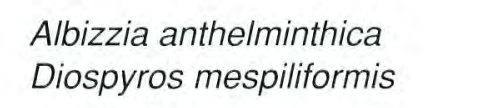 & 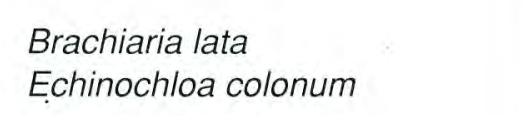 & villages and crops in major valleys \\
\hline & хв3 & $\begin{array}{l}\text { eroded pediplinas, regs } \\
\text { and storyy pataua }\end{array}$ & very sparse & 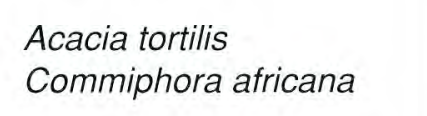 & 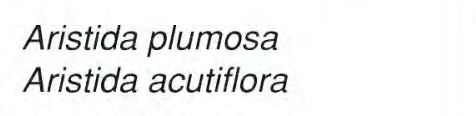 & 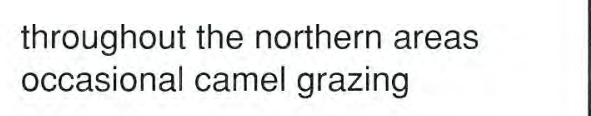 & & sv2 & 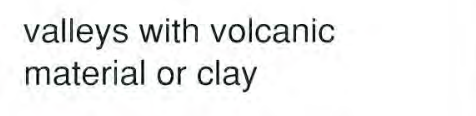 & densely woody & 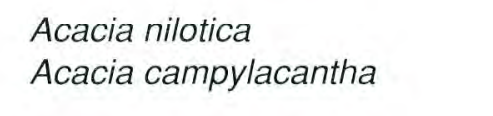 & 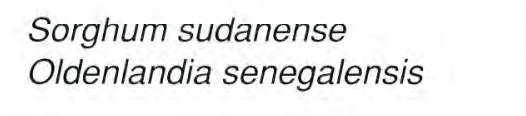 & $\begin{array}{l}\text { volicanic ashes along Wadi E Ku } \\
\text { some fieds }\end{array}$ \\
\hline & X84 & shallow sands on rock & irregular & 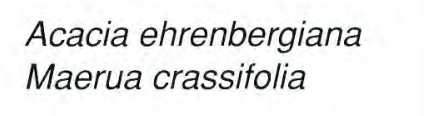 & 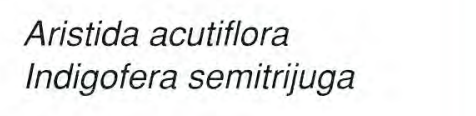 & poor rainy season rangelands & & CR1 & $\begin{array}{l}\text { grannte uutcrops and } \\
\text { inselbergs }\end{array}$ & woodlands & 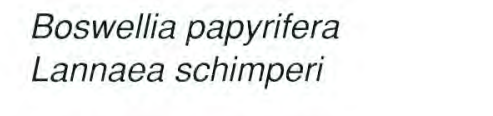 & 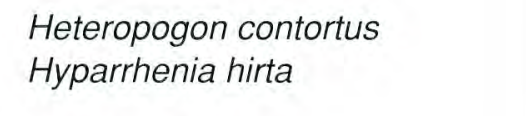 & small scattered jebels \\
\hline & $\mathrm{xs} 1$ & deep sands, plateau & none or limited & $\begin{array}{l}\text { Leptadeniia pyrrotechnica } \\
\text { Acacia senegal }\end{array}$ & $\begin{array}{l}\text { Panicum turgidum } \\
\text { Eragrostis pilosa }\end{array}$ & 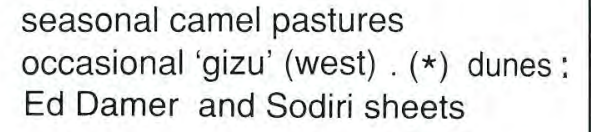 & & CRI' & basaltic ridges & forested along edges & 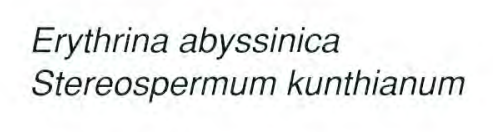 & $\begin{array}{l}\text { Themeda triandra } \\
\text { Hyparthenia spp. }\end{array}$ & $\begin{array}{l}\text { Gallabata area, lower Ethiopian } \\
\text { Mountains }\end{array}$ \\
\hline & xs2 & $\begin{array}{l}\text { undulated ands } \\
\text { sanny yatches }\end{array}$ & none or sparse & $\begin{array}{l}\text { Cadaba spp. } \\
\text { Balantes aegyptiaca }\end{array}$ & $\begin{array}{l}\text { Aristida pallida } \\
\text { Neurada procumbens }\end{array}$ & $\begin{array}{l}\text { on boath sides of A Abara River } \\
\text { wind erosion }\end{array}$ & & CR2 & $\begin{array}{l}\text { banastitic sipeses } \\
\text { and pediments }\end{array}$ & woodlands and forests & $\begin{array}{l}\text { Vitex doniana } \\
\text { Ochna leucophlooos }\end{array}$ & $\begin{array}{l}\text { Hyparrhenia pseudocymbaria } \\
\text { Sporobolus festivus }\end{array}$ & sub-humid zone \\
\hline & $\mathrm{xc1}$ & sand slopes and low-lands & por woody cover & $\begin{array}{l}\text { Acacia tortilis } \\
\text { Capparis tomentosa }\end{array}$ & $\begin{array}{l}\text { Aristida sieberiana } \\
\text { Indigofera oblongifolia }\end{array}$ & $\begin{array}{l}\text { North-Eastern Dartur - } \\
\text { Extensive grazing }\end{array}$ & & CR3 & basaltic plateau & woodland remnants & $\begin{array}{l}\text { Combretum hatrmannianum } \\
\text { Sterecula sestigerara }\end{array}$ & $\begin{array}{l}\text { Hyparthenia confinis } \\
\text { Ischaemun afrum }\end{array}$ & Gedaref basalts, heavily yultivited \\
\hline & $\mathrm{xc2}$ & $\begin{array}{l}\text { Sally yasino of } \\
\text { Waci inunaddam }\end{array}$ & along grtainage line & $\begin{array}{l}\text { Acacice enthenerergiana } \\
\text { Acacic melltera }\end{array}$ & 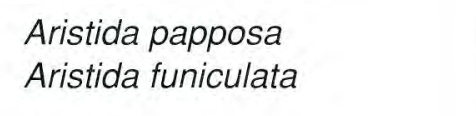 & $\begin{array}{l}\text { wets sasono grzaning, camels } \\
\text { and small runinanis }\end{array}$ & & cs 1 & $\begin{array}{l}\text { supenfiala sands, } \\
\text { somentimes around rocks }\end{array}$ & good cover & $\begin{array}{l}\text { Anogegisusul leicicarus } \\
\text { Sclerocona birea }\end{array}$ & 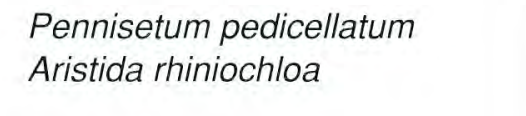 & small areas, no crops \\
\hline & $\mathrm{xc3}$ & salty areas, Gash & " " " " & $\begin{array}{l}\text { Tamarix articulata } \\
\text { Acacia mellifera }\end{array}$ & $\begin{array}{l}\text { Suaeda monoica } \\
\text { Cynodon dactylon }\end{array}$ & $\begin{array}{l}\text { interrupted drainage lines and } \\
\text { shallow run on areas }\end{array}$ & & $\mathrm{cc1}$ & $\begin{array}{l}\text { undifferentiated } \\
\text { plateau on basement }\end{array}$ & $\begin{array}{l}\text { dense homogeneous } \\
\text { cover }\end{array}$ & $\begin{array}{l}\text { Mayterus senegalensis } \\
\text { Terminalia schlweinturthii }\end{array}$ & $\begin{array}{l}\text { Hyparrhenia hirta } \\
\text { Rottboellia exaltata }\end{array}$ & large tracts of mechanized larming \\
\hline & $\mathrm{xc4}$ & $\begin{array}{l}\text { loam and clay deposits } \\
\text { (terraces) }\end{array}$ & medium cover & $\begin{array}{l}\text { Capporis decidua } \\
\text { Ziziphus spina-christi }\end{array}$ & $\begin{array}{l}\text { Cymbopogon proximus } \\
\text { Trianthema }\end{array}$ & $\begin{array}{l}\text { numerous small ponds, wet } \\
\text { seasong grazing }\end{array}$ & & $\mathrm{cc} 2$ & alluvium and lower slopes & partly wooded & $\begin{array}{l}\text { Acacia sieberiana } \\
\text { Acacia seyal var. fistula }\end{array}$ & 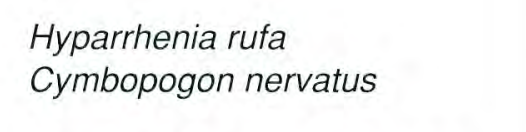 & 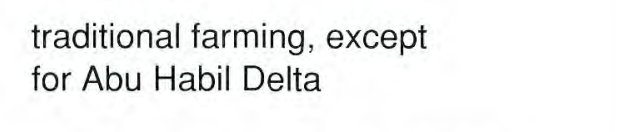 \\
\hline & $\mathrm{xv} 1$ & sandy lowands and valleys & good plant cover & $\begin{array}{l}\text { Balantites aegystiaca } \\
\text { Maerva crassitiaia }\end{array}$ & $\begin{array}{l}\text { Chloris srieuriti } \\
\text { Neurarad r rocumbens }\end{array}$ & good grazing areas & & cc3 & $\begin{array}{l}\text { eredoded river banks } \\
\text { and slopes }\end{array}$ & $\begin{array}{l}\text { treses raund } \\
\text { temporan ponds }\end{array}$ & $\begin{array}{l}\text { Balantite seagyotiaca } \\
\text { Acacica nubica }\end{array}$ & $\begin{array}{l}\text { Cymbopogonor shroenant } \\
\text { Setariainincrassata }\end{array}$ & severe erosion, limited cropping \\
\hline & $\mathrm{xv2}$ & volcanic alluvium & good woody cover & $\begin{array}{l}\text { Acacaiainititaca } \\
\text { Accaia seyal }\end{array}$ & $\begin{array}{l}\text { Schooneteflidiagracilis } \\
\text { Setataria verticillata }\end{array}$ & 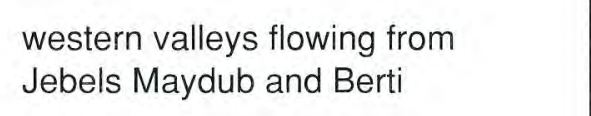 & & cc4 & $\begin{array}{l}\text { degraded banks of } \\
\text { maior rivers }\end{array}$ & poor vegetation & $\begin{array}{l}\text { Calotropis procera } \\
\text { Ziziphus mucronatata }\end{array}$ & $\begin{array}{l}\text { Chloris insosa } \\
\text { Penninesum ramosum }\end{array}$ & $\begin{array}{l}\text { narrover partis of A Abara and } \\
\text { White }\end{array}$ \\
\hline & AR1 & $\begin{array}{l}\text { basemennt and sandstone } \\
\text { mamsits }\end{array}$ & mainly woody & 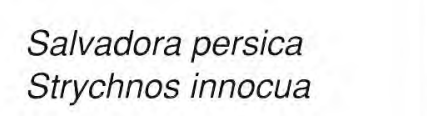 & 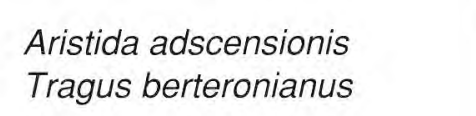 & mosty in Datur & & cv1 & 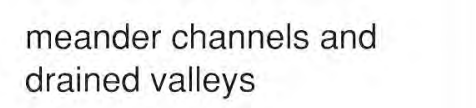 & good grasslands & Hyphaene thebaica & $\begin{array}{l}\text { Cynndon dactyon } \\
\text { Sorghum virgatum }\end{array}$ & $\begin{array}{l}\text { some irigiatedd crops, } \\
\text { recent alluvium }\end{array}$ \\
\hline & AR2 & $\begin{array}{l}\text { eroded or indurated } \\
\text { plateaus }\end{array}$ & poor cover & $\begin{array}{l}\text { Commiphora africana } \\
\text { Acacia mellifera }\end{array}$ & $\begin{array}{l}\text { Cenchrus bitious } \\
\text { Arsistid tuniculatata }\end{array}$ & $\begin{array}{l}\text { and Betrif sometimes with small } \\
\text { sand rifges (*) }\end{array}$ & & cv2 & alluvial plains & very good plant cover & $\begin{array}{l}\text { Ficus thonningui } \\
\text { Acacia ehrenbergiana }\end{array}$ & $\begin{array}{l}\text { Hyparrteniar ruta } \\
\text { Schizachyrum exile }\end{array}$ & $\begin{array}{l}\text { often cultivated in the South-East } \\
\text { of the ecozonene }\end{array}$ \\
\hline & AR3 & sand sheet on rocky slopes & sparse woody cover & $\begin{array}{l}\text { Acacia tortilis } \\
\text { Leptadenia pyrotechnica }\end{array}$ & 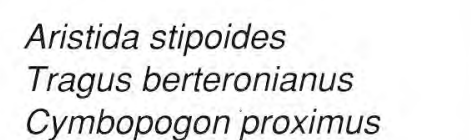 & 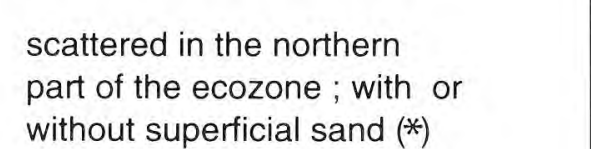 & & cv3 & upstream river valleys & riverine gallery & $\begin{array}{l}\text { Acacia nintioici } \\
\text { Heeria insignis }\end{array}$ & 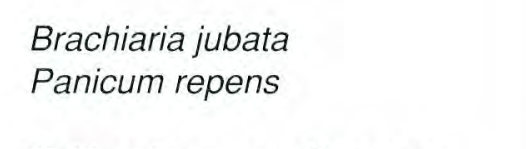 & Dinder National Park area \\
\hline & AS1 & sand plains & homogeneous medium & $\begin{array}{l}\text { Acacia senegeal } \\
\text { Aacia conaqla }\end{array}$ & 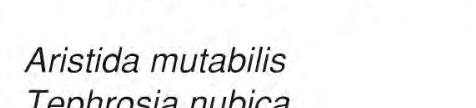 & from El Fasher to the White Nile & & & flood zones & aquatic grassslands & none & 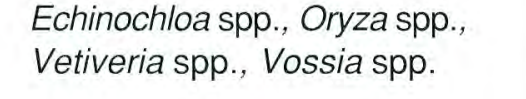 & along both White and Blue Niles \\
\hline & AS 1 & Kheiran duneses" & higher cover in the & Acacia raddiana & Cenchrus bifitorus & longitudinal dunes or transverse & & MF1 & granite and schist mass & $\begin{array}{l}\text { heterogeneous woody } \\
\text { cover }\end{array}$ & 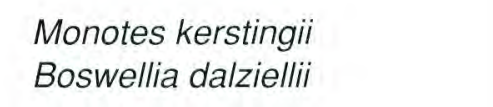 & $\begin{array}{l}\text { Loudetia togoonsis } \\
\text { Hyyartrenia baguirmica }\end{array}$ & South-Western mountains \\
\hline & & & & 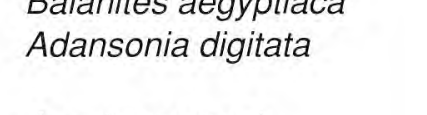 & $\begin{array}{l}\text { Lesarum natured } \\
\text { sesamum alutum }\end{array}$ & & & $\mathrm{MR}^{\mathrm{b}}$ & Jebel Mara basatts & $\begin{array}{l}\text { mountain grasslands } \\
\text { and savanas }\end{array}$ & $\begin{array}{l}\text { Anogoissus leicocarpus } \\
\text { Oloa laperirei }\end{array}$ & $\begin{array}{l}\text { Andropogon distach hyos } \\
\text { Antheophora elagans }\end{array}$ & 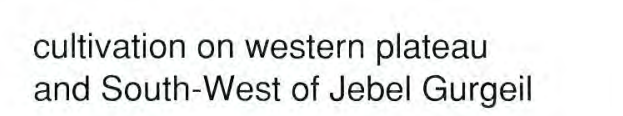 \\
\hline & AS2 & goz undulating sands & homogeneoous vegetatio & 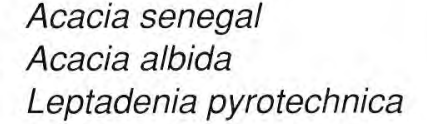 & 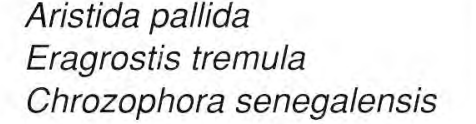 & $\begin{array}{l}\text { scaterefec cultivation; } \\
\text { gum bett, over grazed }\end{array}$ & & MR2 & slopes and sandstone hills & $\begin{array}{l}\text { wooded grassinans, } \\
\text { patchy yover }\end{array}$ & $\begin{array}{l}\text { Combertum glutinosum } \\
\text { Anfogeissus leficarus }\end{array}$ & 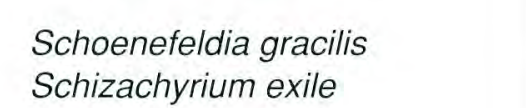 & $\begin{array}{l}\text { around the maijor } \\
\text { basement massiss }\end{array}$ \\
\hline & AC1 & $\begin{array}{l}\text { eroded slopes along } \\
\text { riviv beds }\end{array}$ & degraded & $\begin{array}{l}\text { Balantites aegypticaca } \\
\text { Acaci nubica }\end{array}$ & 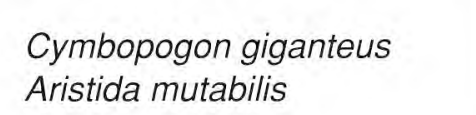 & spectific to Darurur & & $\mathrm{MR}^{\mathrm{b}}$ & basallicic slopes and hills & $\begin{array}{l}\text { open savanna on } \\
\text { achs piedromit }\end{array}$ & 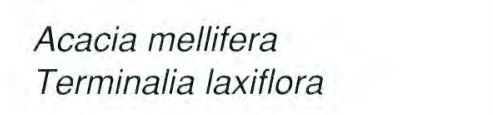 & 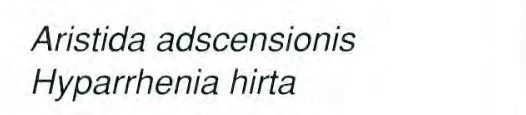 & $\begin{array}{l}\text { good grazing areas, } \\
\text { somem cutluvation }\end{array}$ \\
\hline & AC2 & limestone bottomlands & contracted woody layer & $\begin{array}{l}\text { Acacia mellifira } \\
\text { Acacic radiana }\end{array}$ & $\begin{array}{l}\text { Schoneneteldia gracilis } \\
\text { Sorothum }\end{array}$ & close to Kordofan rock outcrops & & MR3 & $\begin{array}{l}\text { lower slopes and regs } \\
\text { on gneniss }\end{array}$ & $\begin{array}{l}\text { concentrated in } \\
\text { drainages }\end{array}$ & 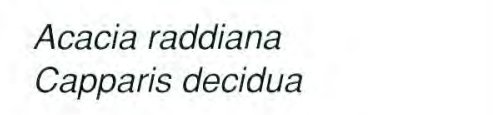 & 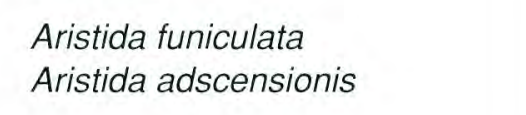 & northern areas, beyond $14^{\circ} \mathrm{N}$ \\
\hline & AC3 & $\begin{array}{l}\text { endoreici lowlands on } \\
\text { fifenteturudd soils }\end{array}$ & good plant cover & $\begin{array}{l}\text { Acacia mellifera } \\
\text { Acacic nubica }\end{array}$ & $\begin{array}{l}\text { Cymbopogon proximus } \\
\text { cyerus songlomeratus }\end{array}$ & $\begin{array}{l}\text { sometimes overgrazed and with } \\
\text { bush encroachment }\end{array}$ & & MF4 & $\begin{array}{l}\text { sandy pediplain and } \\
\text { lower slopes }\end{array}$ & $\begin{array}{l}\text { good homogeneous } \\
\text { tree cover }\end{array}$ & $\begin{array}{l}\text { Balanites aegyptiaca } \\
\text { Terminalia spp. }\end{array}$ & 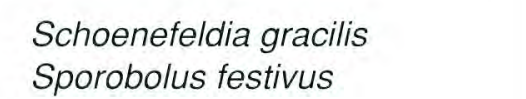 & thicker sandy layer, south of $14^{4} \mathrm{~N}$ \\
\hline & Av1 & sandy valleys & medium cover & 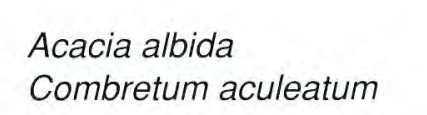 & 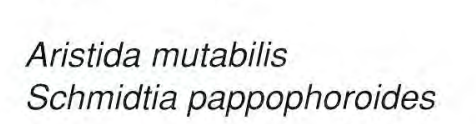 & $\begin{array}{l}\text { favorable water budget } \\
\text { seasonal grazing }\end{array}$ & & ms1 & sand plateau & fair grass cover & $\begin{array}{l}\text { Acacia raddiana } \\
\text { Commiphora atricana }\end{array}$ & $\begin{array}{l}\text { Aristida mutabilis } \\
\text { Alysicarpus ovalifolius }\end{array}$ & $\begin{array}{l}\text { many fields close to Geneina } \\
\text { and lvifida }\end{array}$ \\
\hline & Av2 & loamiclay vallyys & densely woody & $\begin{array}{l}\text { Acaciais seyal } \\
\text { Acacia aliotica }\end{array}$ & $\begin{array}{l}\text { Cymbopogon nervatus } \\
\text { Spporoblus humitusus }\end{array}$ & temporary water-logging & & MS2 & sand and sands sheets & increasing south-wards & $\begin{array}{l}\text { Combretumum glturinsum } \\
\text { Anogegisus leitcoarus }\end{array}$ & $\begin{array}{l}\text { Cenchtrus bifitorus } \\
\text { Eragrosist tremula }\end{array}$ & NE-SW oriented i n narrow stripes \\
\hline & LR1 & rock outcrops & poor plant cover & 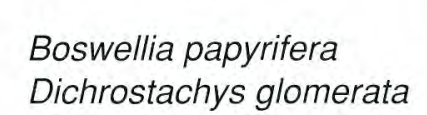 & 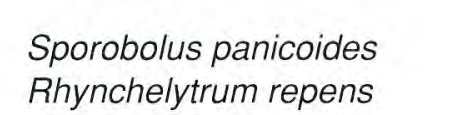 & some sandy patches & & MC1 & $\begin{array}{l}\text { dissected slopes and } \\
\text { plateau }\end{array}$ & dense woody cover & $\begin{array}{l}\text { Acaciam mellitera } \\
\text { Acacicalata }\end{array}$ & $\begin{array}{l}\text { Hyparthenia pserdoconmbaria } \\
\text { Cymbopogono proximus }\end{array}$ & $\begin{array}{l}\text { transition from Jebel Mara to } \\
\text { semi-arid decozone }\end{array}$ \\
\hline & Ls1 & sandy higher grounds & irregular medium cover & $\begin{array}{l}\text { Acacia senegeal } \\
\text { Marera crassifolia }\end{array}$ & $\begin{array}{l}\text { Aristidida adscensionis } \\
\text { Cenchrus prieurii }\end{array}$ & few locations East of Blue Nile & & MC2 & $\begin{array}{l}\text { run-on areas and terraces, } \\
\text { clay-loamm }\end{array}$ & $\begin{array}{l}\text { trees along drainage } \\
\text { lines }\end{array}$ & $\begin{array}{l}\text { Tamarindus indica } \\
\text { Acacia gerrardii }\end{array}$ & 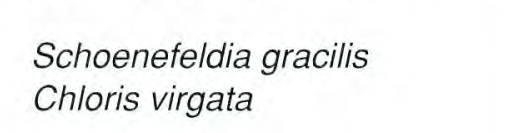 & $\begin{array}{l}\text { Waditibu Aradei vally, } \\
\text { no no untivation }\end{array}$ \\
\hline & LS2 & sands, recent Gash Delta & $\begin{array}{l}\text { poor excepp in } \\
\text { interciune tatats }\end{array}$ & 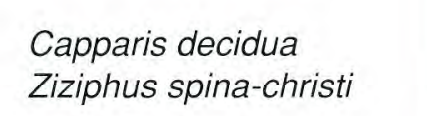 & 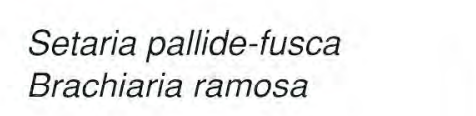 & $\begin{array}{l}\text { undulating sands, wet season } \\
\text { grazing }\end{array}$ & & MV1 & sandy valleys and lowlands & riverine tormation & 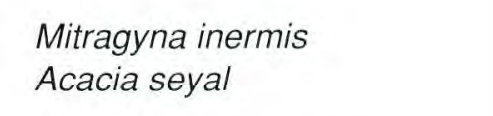 & 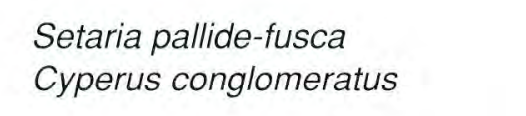 & nothern ecczone \\
\hline & Ls3 & sandy terraces & otten degraded & $\begin{array}{l}\text { Mitragyna inermis } \\
\text { Ziziphus mucronata }\end{array}$ & 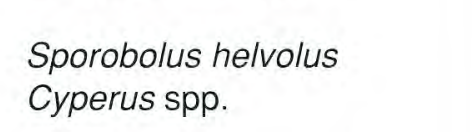 & isolated fields, overgrazed & & MV2 & southerr valleys & woodlands & $\begin{array}{l}\text { Syrygum usineense } \\
\text { Accacia albida }\end{array}$ & 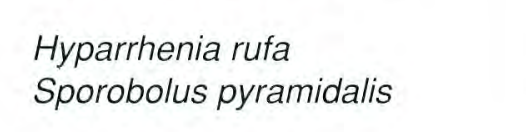 & $\begin{array}{l}\text { many } \\
\text { much permanantitint rivers, }\end{array}$ \\
\hline & LC1 & clay plateau & homogeneous, poor & 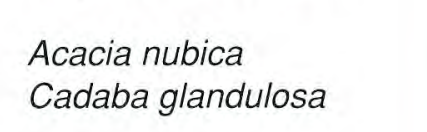 & 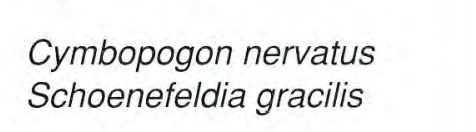 & large areas without drainagege & & MV2' & $\begin{array}{l}\text { valyely fflub by } \\
\text { volcanic material }\end{array}$ & 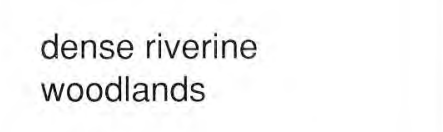 & $\begin{array}{l}\text { Diospyros mespiliformis } \\
\text { Teclea nobilis }\end{array}$ & $\begin{array}{l}\text { Selatis spop. coloum } \\
\text { Echinochliba coloum }\end{array}$ & traditional crops \\
\hline & LC2 & aggradational clays & $\begin{array}{l}\text { medium, mainly in } \\
\text { drainage lines }\end{array}$ & 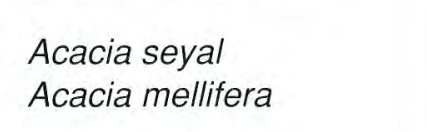 & $\begin{array}{l}\text { Cymbopogon nevatus } \\
\text { Aristidid hordeacead }\end{array}$ & around major ririgation schemes & & ic & irrigation schemes & $\begin{array}{l}\text { crops: coton, wheat } \\
\text { vegetables, groundnuts }\end{array}$ & & 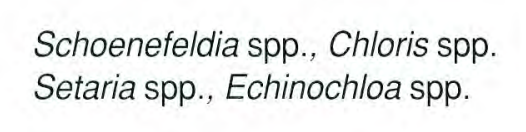 & $\begin{array}{l}\text { aridand sanem-inid areas } \\
\text { with clay solis }\end{array}$ \\
\hline & LC3 & degradational clays & scattered, heterogene & $\begin{array}{l}\text { Acacia nubica } \\
\text { Cadabab rotundifolia }\end{array}$ & $\begin{array}{l}\text { Tetrapogon spathaceus } \\
\text { Tragus, Ocimum }\end{array}$ & $\begin{array}{l}\text { centrat Butanan and } \\
\text { Oold Gash Deta }\end{array}$ & & мс & mechanized tarms & $\begin{array}{l}\text { crops: dura, sesame, } \\
\text { sunflower }\end{array}$ & & $\begin{array}{l}\text { Pennisetum ramosum } \\
\text { Selataia verticiliata }\end{array}$ & semiarid ecozone \\
\hline & LC4 & eroded slopes along rivers & reduced & $\begin{array}{l}\text { Cordia rothir } \\
\text { Calotropis procera }\end{array}$ & $\begin{array}{l}\text { Cymbopogon nervatus } \\
\text { Sporobolus marginatus }\end{array}$ & 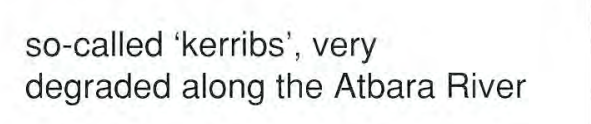 & & TC & traditional crops & $\begin{array}{l}\text { durtar milet, beans, } \\
\text { groundunus }\end{array}$ & & $\begin{array}{l}\text { Pennnistum mpsp. } \\
\text { Chloris, Eragrosisis }\end{array}$ & include fallows \\
\hline & LV1 & narrow clay valleys & good woody cover & $\begin{array}{l}\text { Acacici siberiana } \\
\text { Acacaiaseral }\end{array}$ & 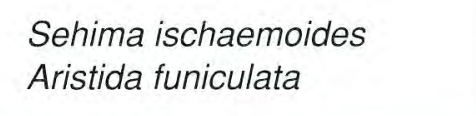 & temporary flooding & & w & streams and lakes & & & & \\
\hline
\end{tabular}






TOPOGRAPHY
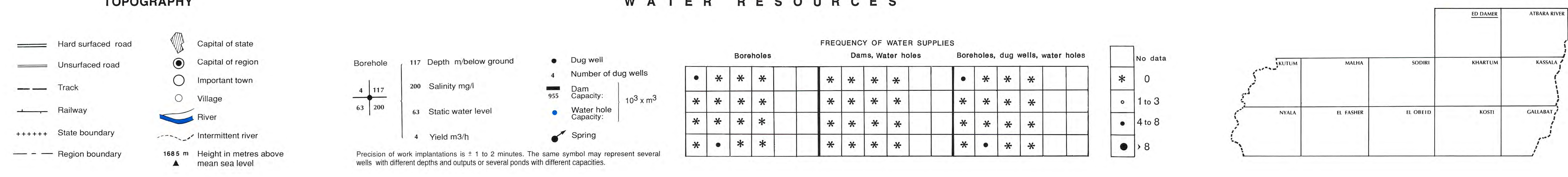




TOPOGRAPHY

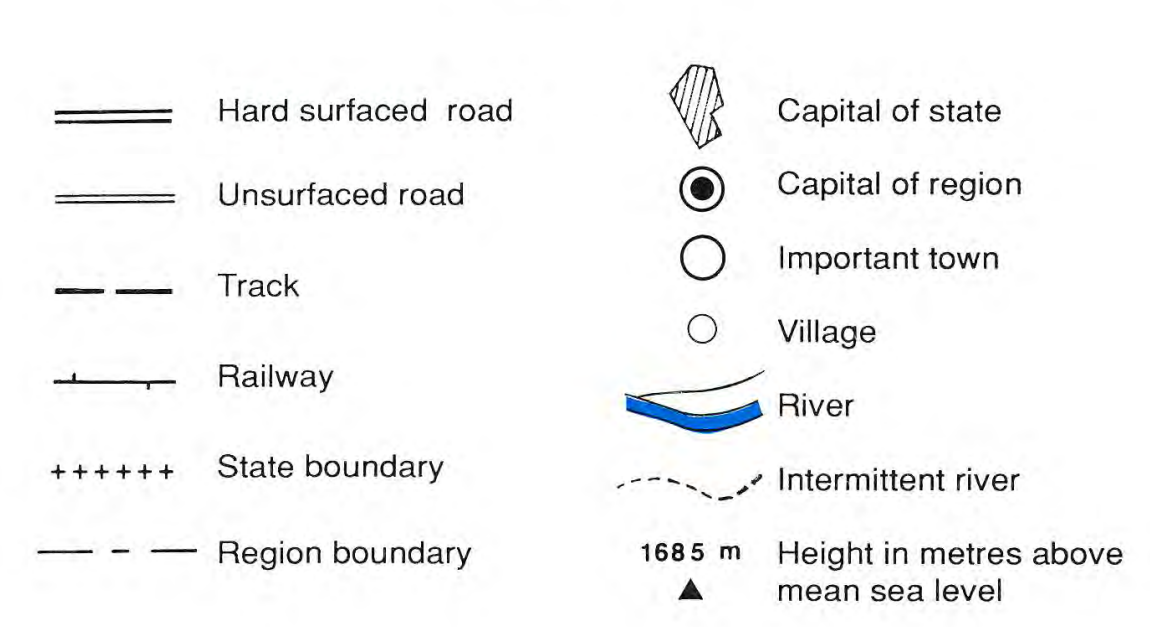

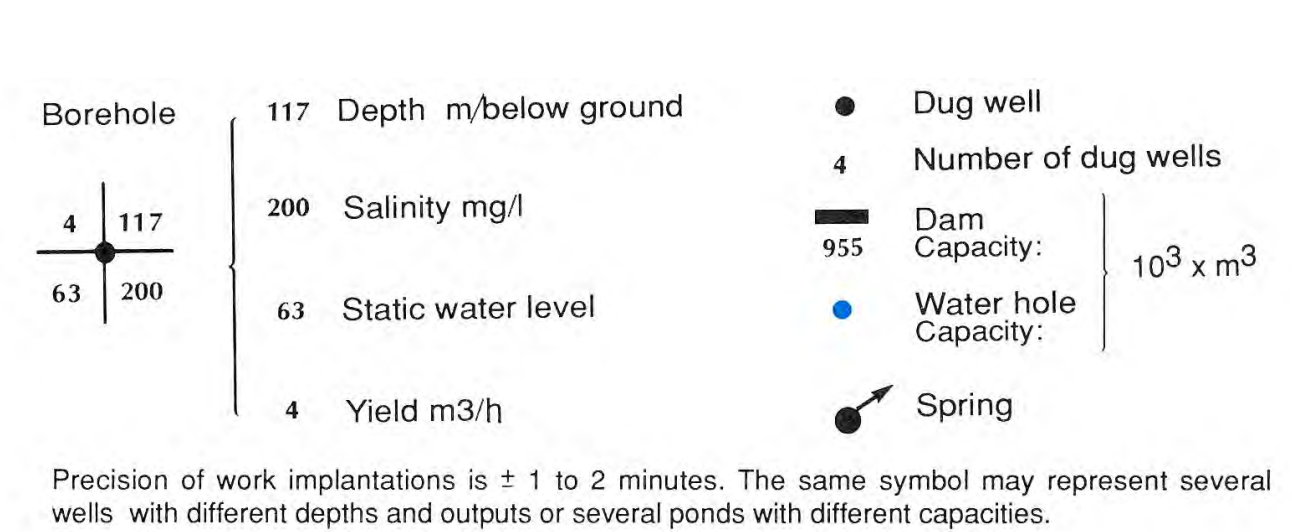

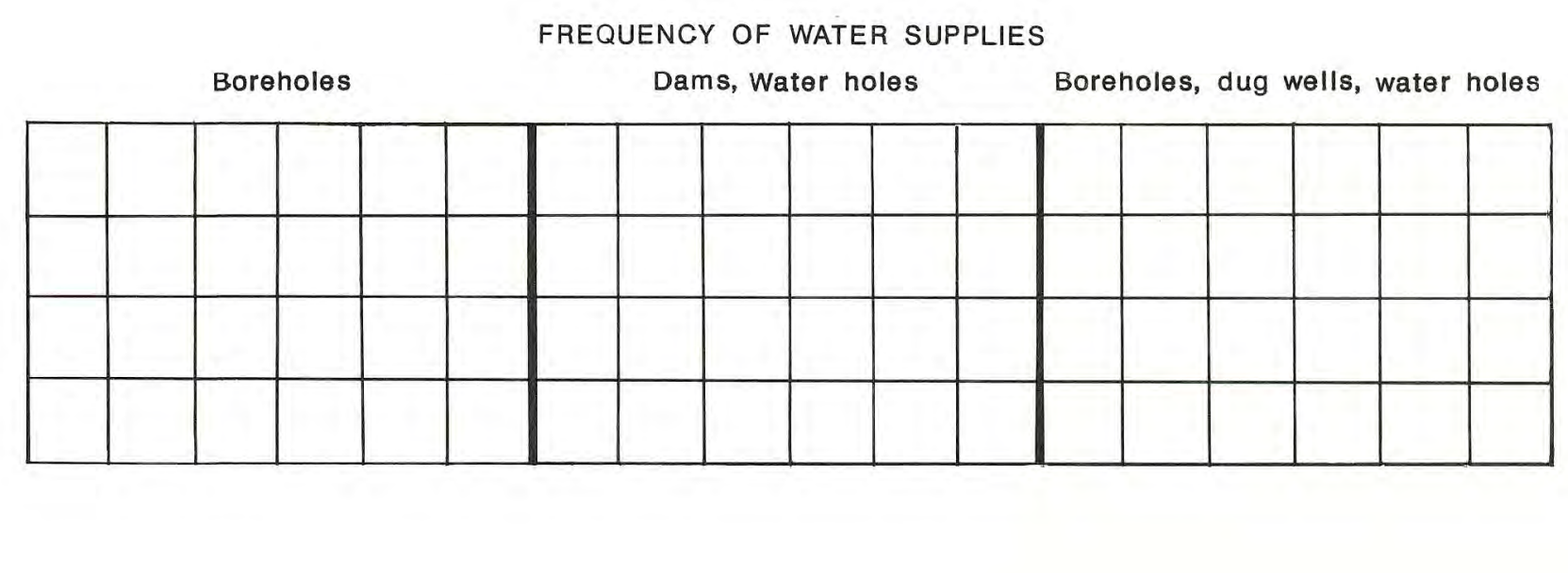

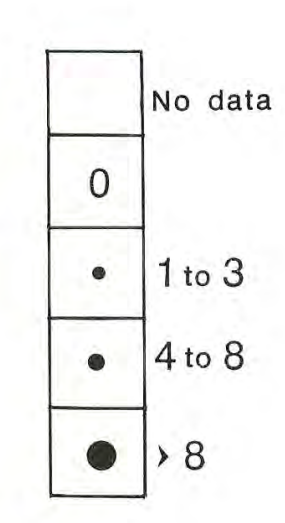






TOPOGRAPHY

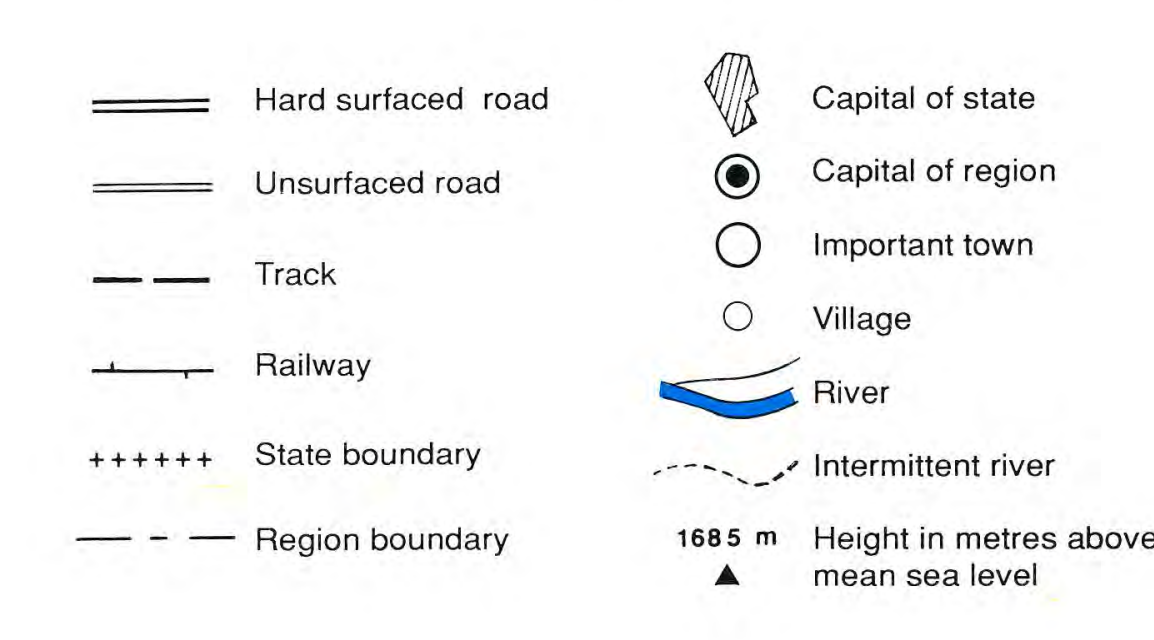

W A TE R RESOU R C E
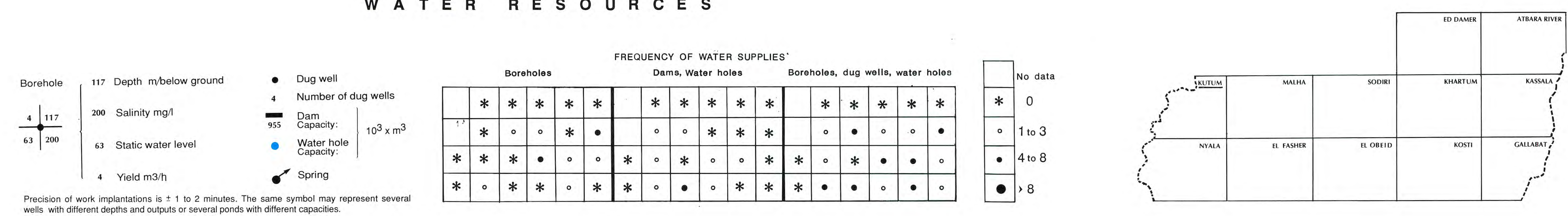


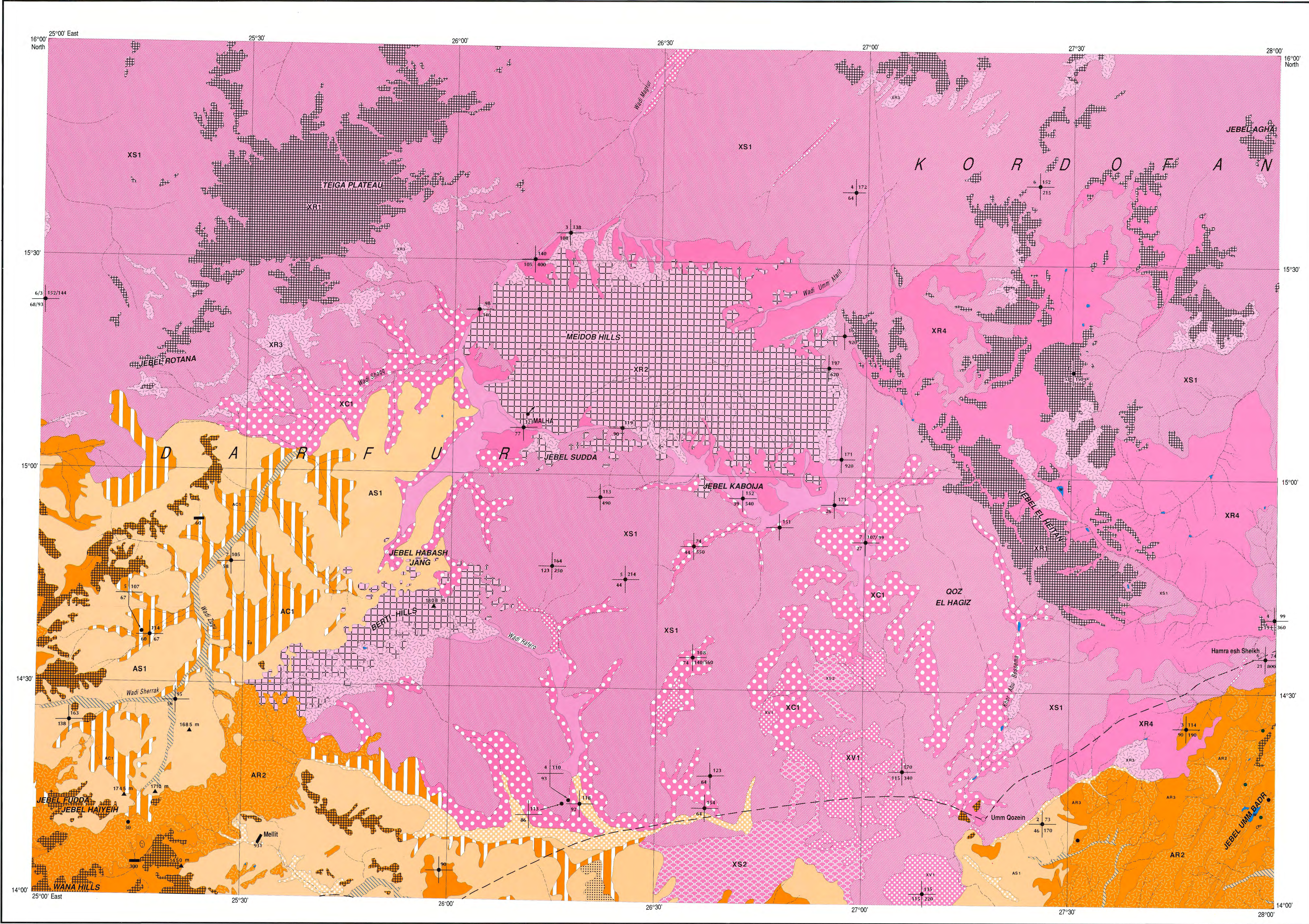

TOPOGRAPHY
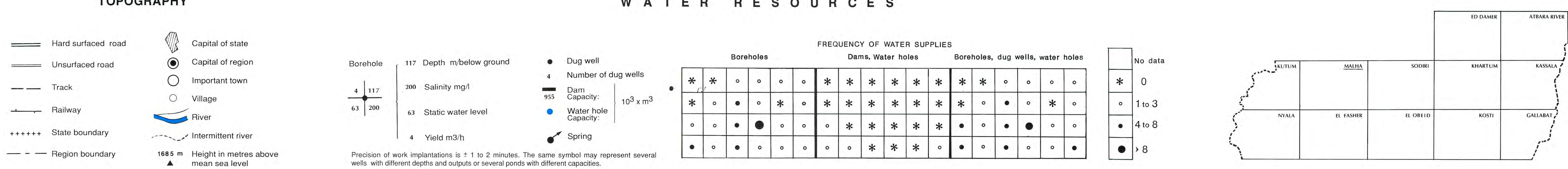




TOPOGRAPHY
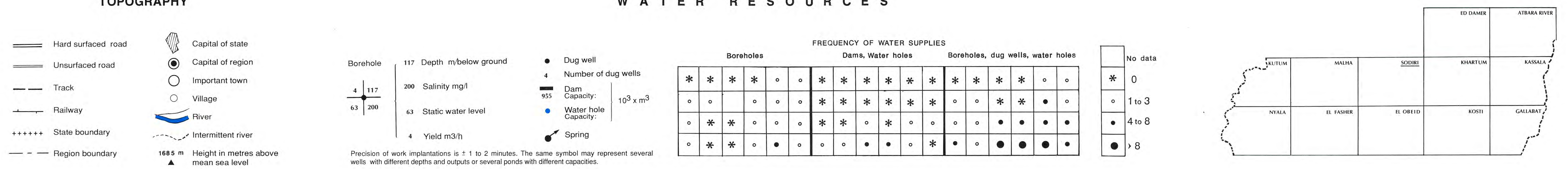


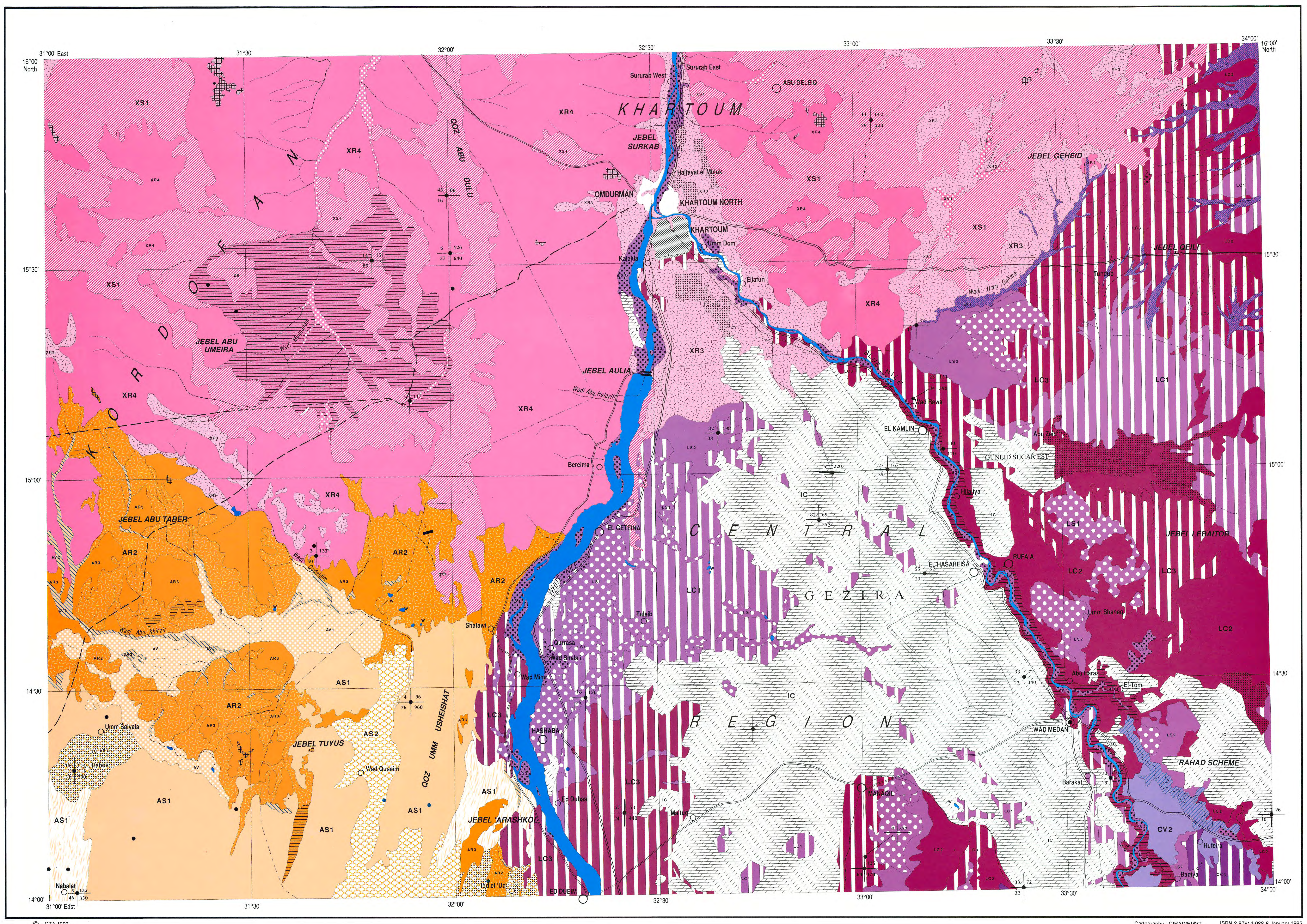

TOPOGRAPHY

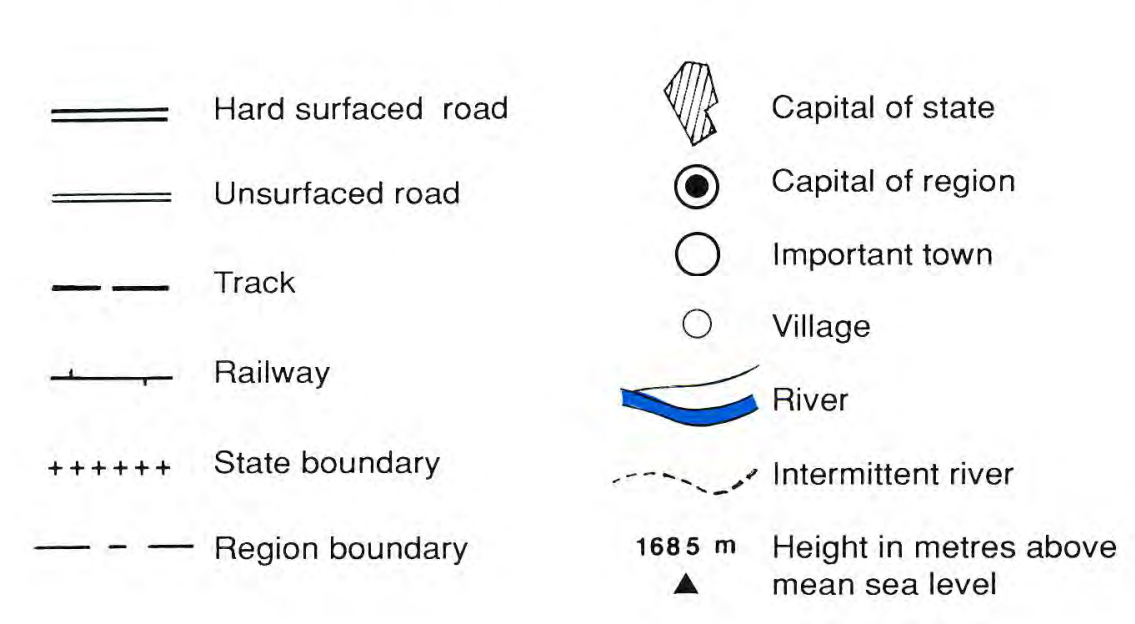

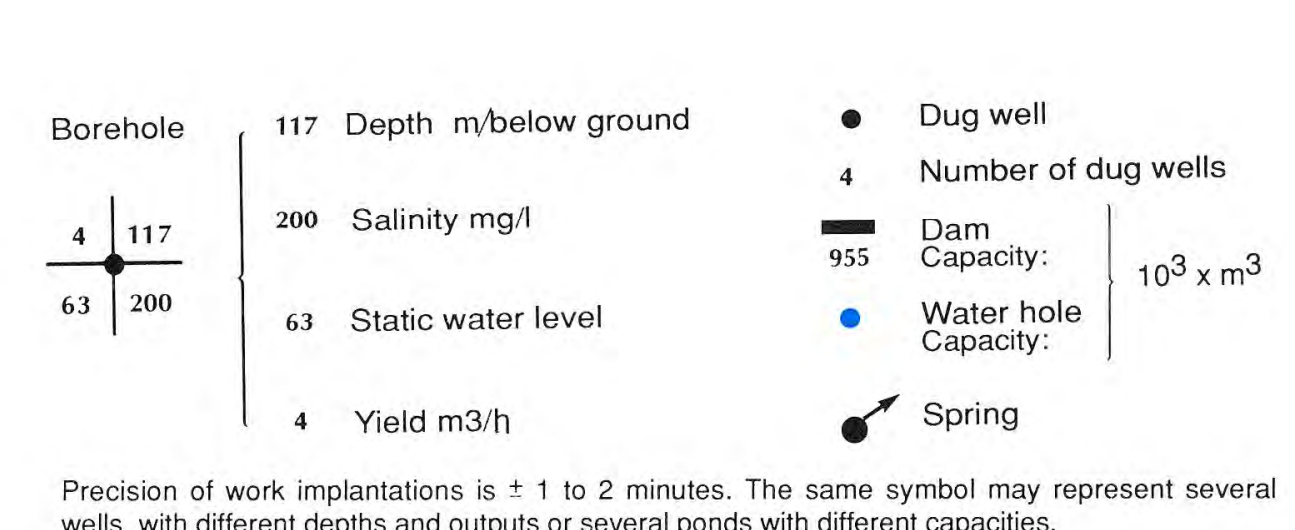

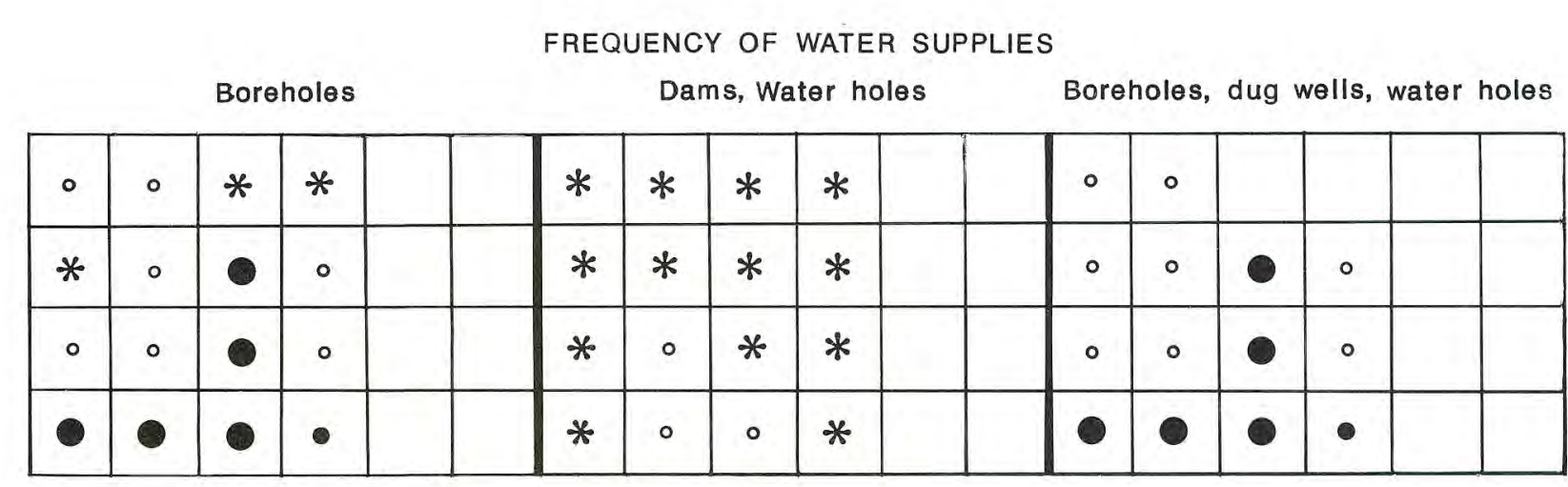

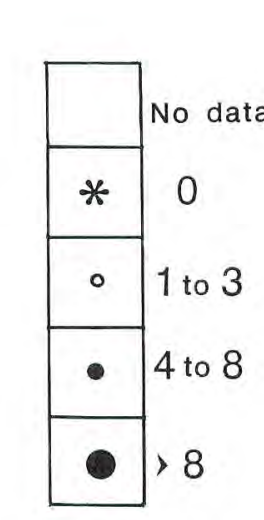




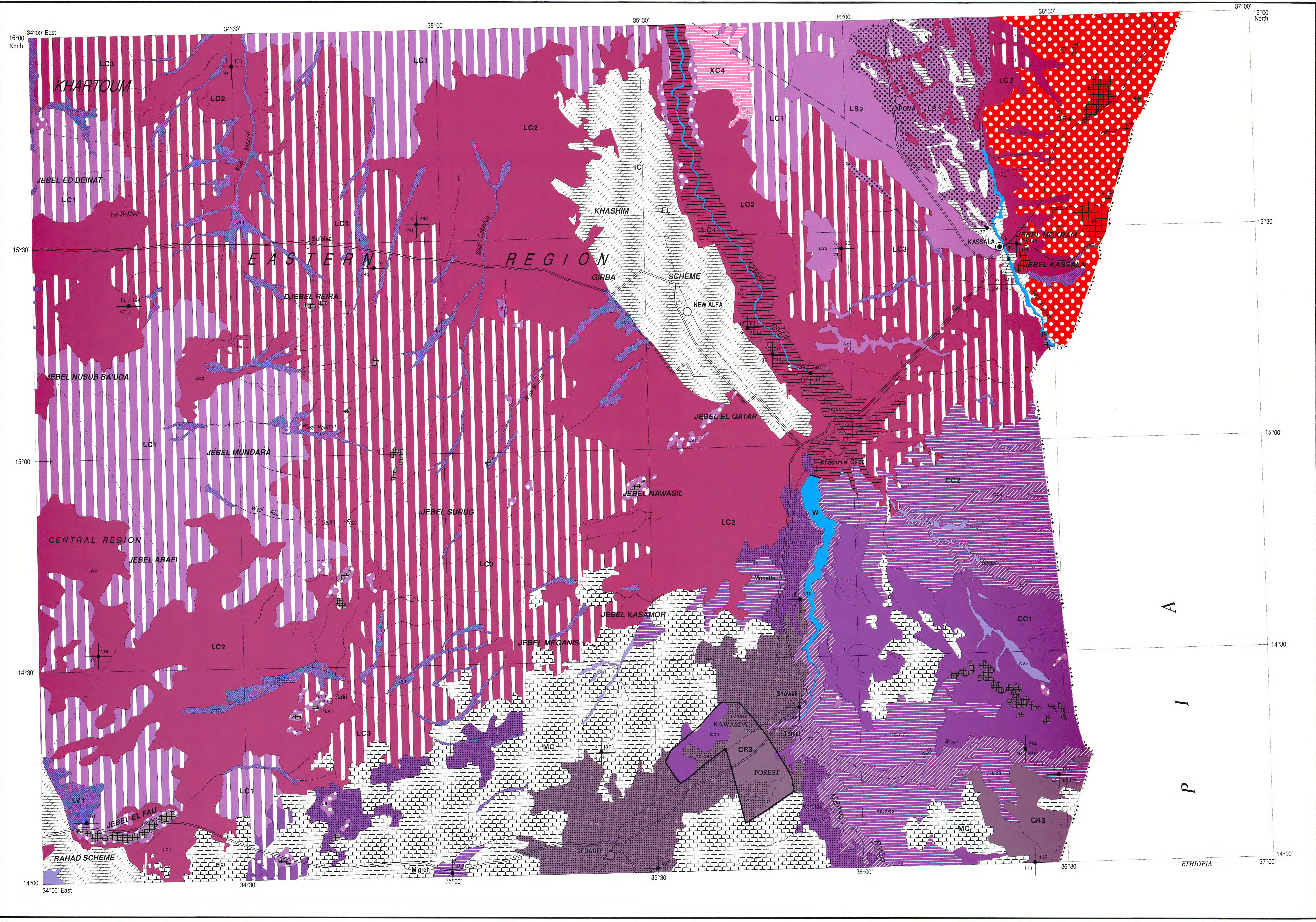

TOPOGRAPHY
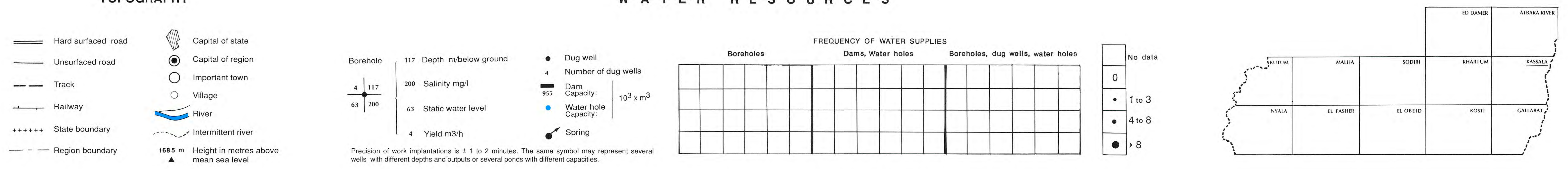




TOPOGRAPHY
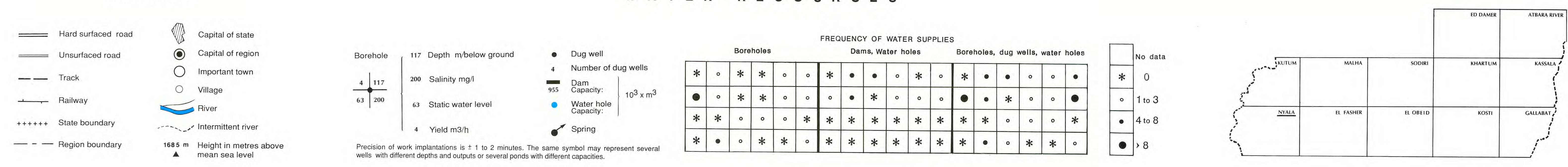


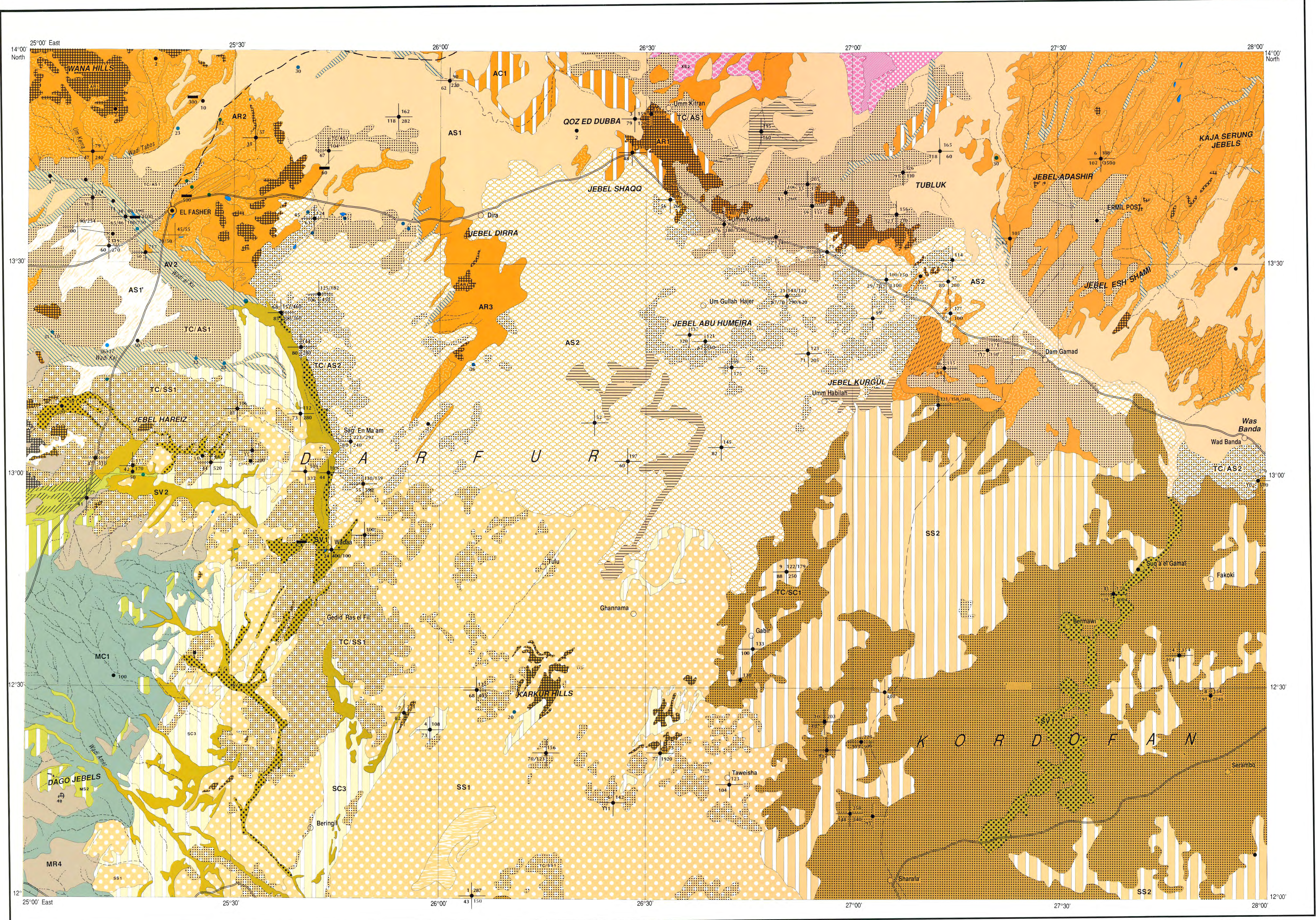

TOPOGRAPHY
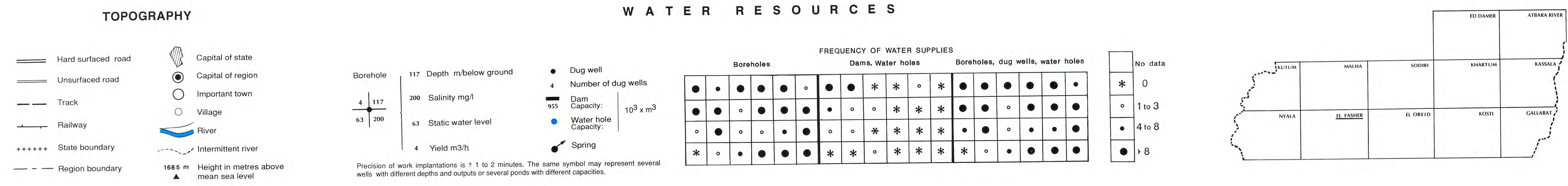

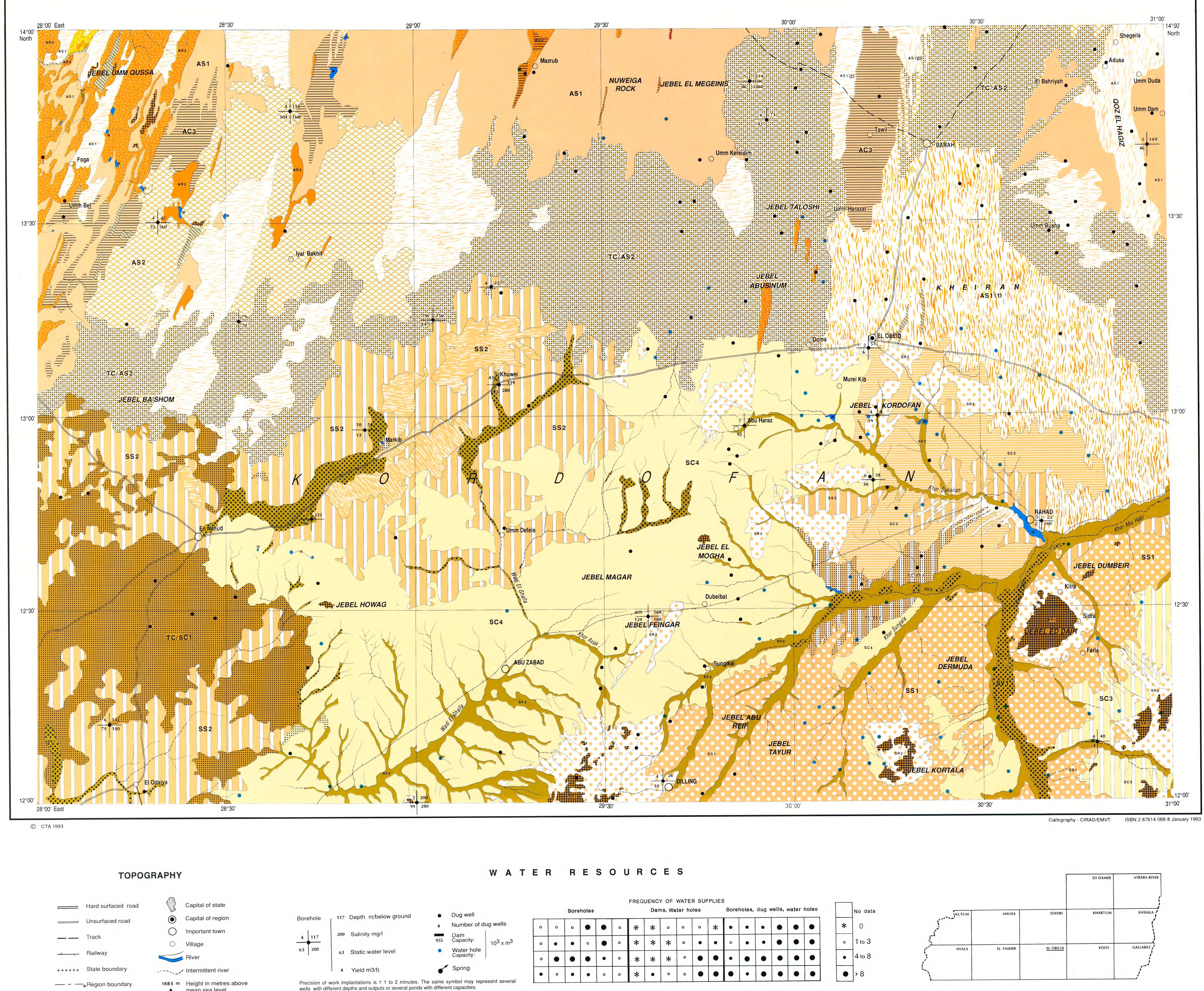


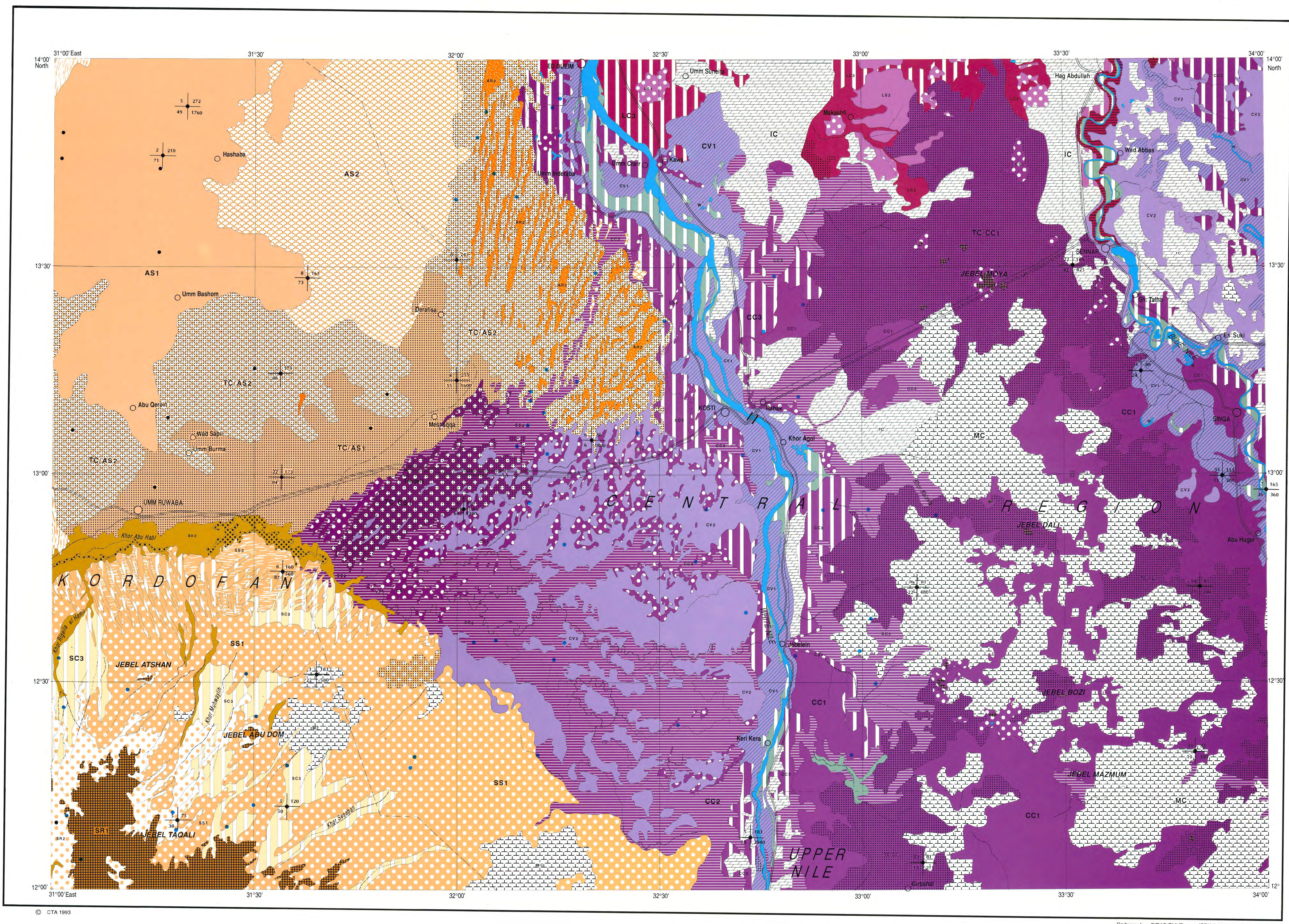

TOPOGRAPHY
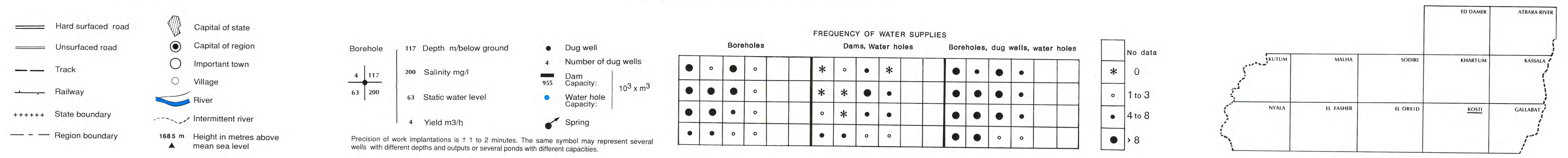


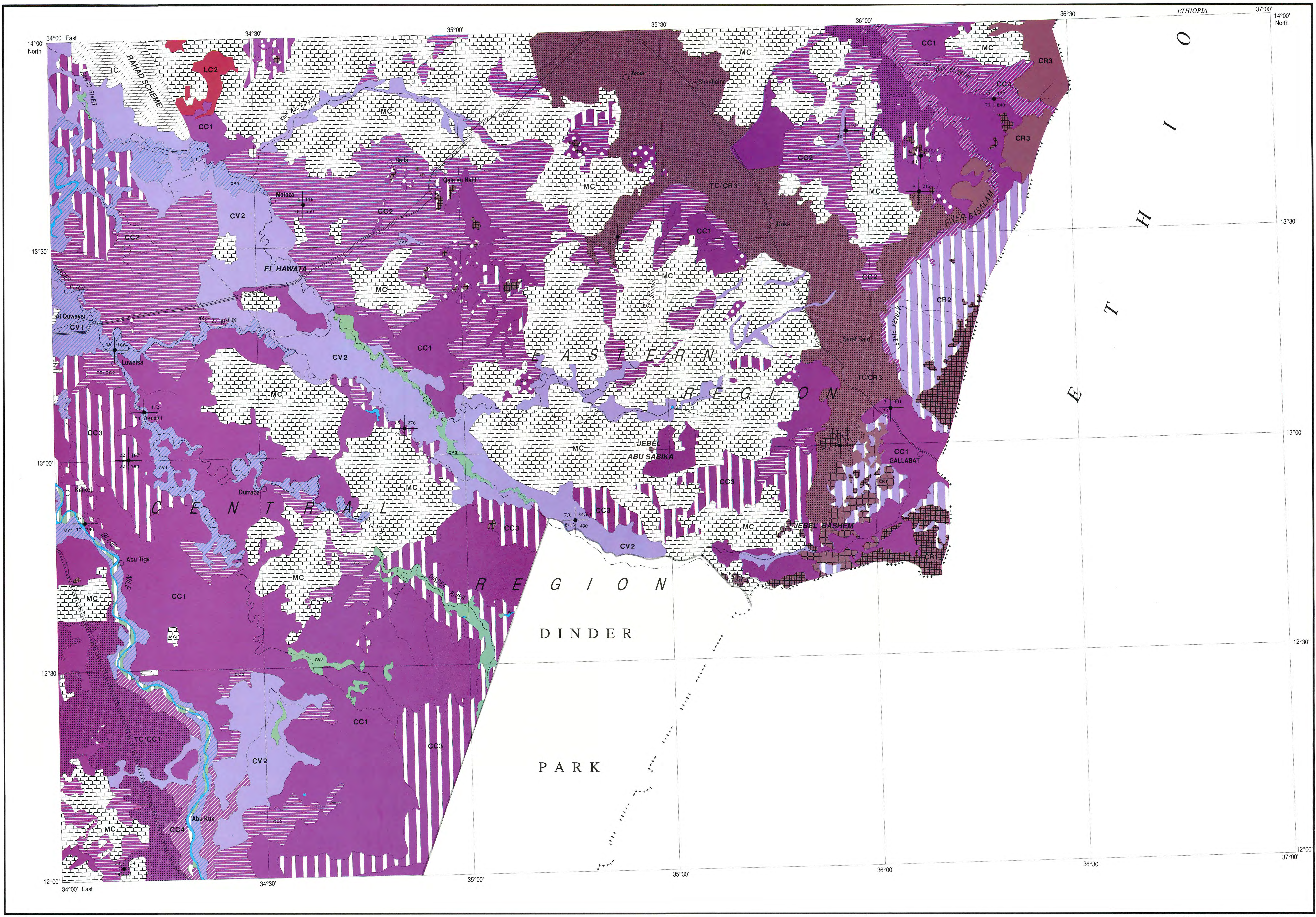

TOPOGRAPHY

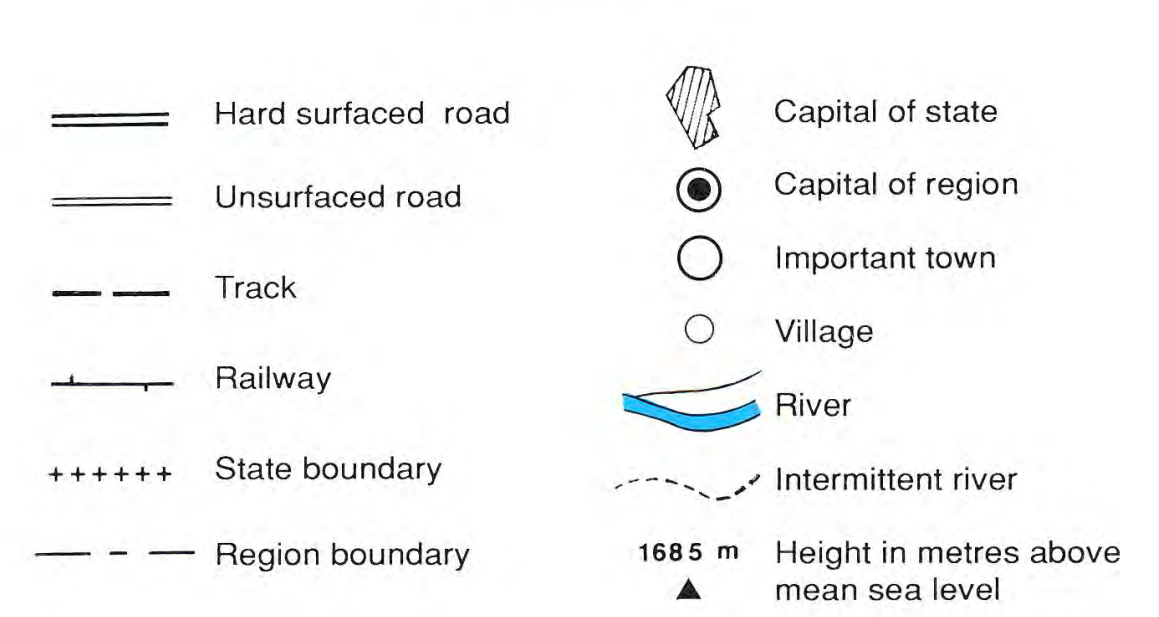

W A TER RESOURCES
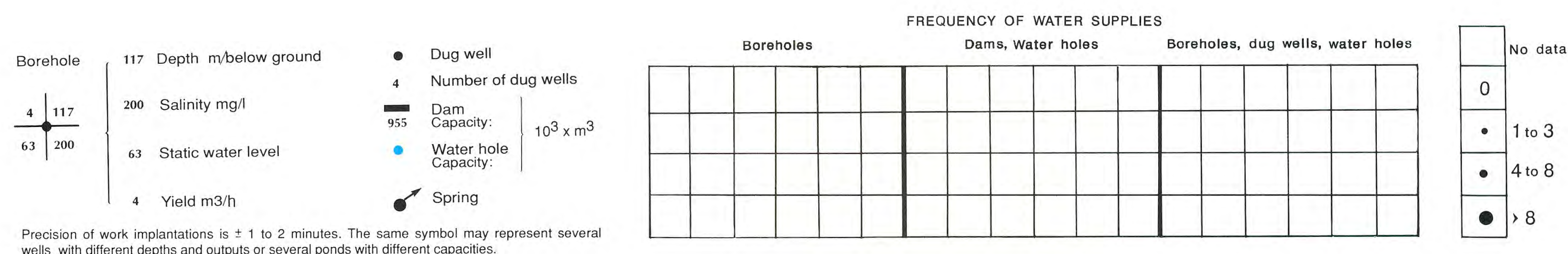
El Moulah Fald, De Zborowski Isolde. 1993. Climate and soils. In : Livestock production and sahelian rangelands potential: Republic of Sudan = Élevage et potentialités pastorales sahéliennes $:$ République du Soudan. Darag A., Lamarque Georges. CIRAD-IEMVT - FRA. Wageningen : CTA-CIRAD-IEMVT, 18-19. ISBN 2-87614-088-8

\section{CLIMATE AND SOILS}

\section{FALD EL MOULAH}

\section{CLIMATE}

The whole range of tropical climates is found in Sudan, from true desert with no rainy month, to the wet tropical type of the southern frontier with a dry season of only three or four months. Generally the climate is of the continental type in which the diurnal variation of temperature often exceeds $15^{\circ} \mathrm{C}$. In the south of the country the highest temperatures occur in March and April: at the higher latitudes to the north the highest temperatures are delayed to May to July. Outside the southern provinces maximum temperatures often exceed $40^{\circ} \mathrm{C}$ (Figure 1). North of the 16th parallel and in the mountainous areas the winter nights are cool.

Rainfall is highly seasonal and is governed by the northward advance of the monsoonal Intertropical Convergence Zone. The rainfall pattern is unimodal, the peak reaching a maximum in July and August. Several natural, and traditionally described, climatic zones can be distinguished, from north to south:

- the desert proper, covering $24 \%$ of the country's area, where average annual rainfall is less than $50 \mathrm{~mm}$ but where it may not actually rain for several years (this zone may very occasionally be subject to Mediterranean influence and have rain in the winter); 
- the semi-desert, which also covers $24 \%$ of the country, and which receives $75.300 \mathrm{~mm}$ of rain per year falling in one or two months only, following the hottest period, and where no rainfed cultivation is possible:

- the arid zone, covering $10 \%$ of the country, with annual rainfall between 300 and $500 \mathrm{~mm}$, which allows rainfed cultivation of some specialized short-season crops, although this area is principally of importance (as is the previous one) in its support of the nomadic and semi-nomadic livestock production systems;

- the semi-arid and subhumid regions, which together cover $26 \%$ of the country, and where rainfall is between 500 and $1000 \mathrm{~mm}$ per year;

- the remainder of the country, which has a humid climate or is covered by swamps.

Such a general classification is obviously subject to several local modifications. The Red Sea, for example, governs a special climatic regime along a narrow strip: inland to the coastal mountain ranges, where temperature variations are less extreme and where the rain, while still being small in amount, is more regularly distributed. In the south-east of the country a small arid area is less subject to the influence of the ITCZ and there is here a bimodal tendency in the rainfall pattern. The mountainous areas are both cooler and wetter than their immediate surroundings: Jebel Marra has heavier rains than the rest of Dafiur, even thougli iney lall in a reatively short period; the Nuba Mountains cause the general isohyets to inflect towards the north; and the southern highlands and the foothills of the Ethiopian massif also have heavier rains than would otherwise be the case in those general areas. 


\section{Aridity in Sudan}

The isohyets as drawn provide little more than an indication of the climatic conditions. The potential evapo-transpiration is everywhere very high (from 1600 to $3000 \mathrm{~mm}$ per year) on account of the high temperatures, leading to a humidity index which is negative over most of the country. An index of -66.6 is generally considered to be the boundary between the arid and semiarid regions. In Sudan this index is found at about the $600 \mathrm{~mm}$ isohyet outside the areas that are at higher altitudes, and generally follows the 11th parallel of latitude. Except, however, where irrigation allows a good vegetation cover, actual evapo-transpiration falls far short of the potential, even during the growing season. Reduced vegetative cover and reduced physiological activity of the vegetation are common.

A further factor contributing to the aridity is that only a small proportion of the rain that falls is available to plants. Light rain falling during the hottest hours of the day evaporates immediately and adds nothing to the soil water bank. Heavy rains usually exceed the infiltration rate in to the soil and run-off results in considerable water loss, even in the arid zones. At eight stations receiving between $75 \mathrm{~mm}$ and $820 \mathrm{~mm}$ per year (Table 1) only 20 to $30 \%$ of rain days provide water useful for plant growth. In these areas, rain from a single violent storm may exceed the annual average in the semi-desert regions and can account for a quarter of annual rainfall in the arid zones. The total time during which rain falls in the very arid and arid areas does not usually exceed 100 hours. 
Table 1 - Rainfall frequency and intensity for selected stations in Sudan in period 1931-1960

\begin{tabular}{|c|c|c|c|c|}
\hline Location & $\begin{array}{c}\text { Days with } \\
\text { rain }\end{array}$ & $\begin{array}{c}\text { Falls over } \\
1 \mathrm{~mm}\end{array}$ & $\begin{array}{l}\text { Falls over } \\
10 \mathrm{~mm}\end{array}$ & $\begin{array}{l}\text { Heaviest one } \\
\text { day fall (mm) }\end{array}$ \\
\hline Atbara & 10.6 & 9.0 & 2.0 & 98.1 \\
\hline Khartoum & 21.3 & 19.7 & 5.3 & 79.9 \\
\hline El Fasher & 34,3 & 31.8 & 9.1 & 93.0 \\
\hline Kassala & 33.5 & 30.4 & 11.0 & 95.5 \\
\hline El Obeid & 41.6 & 36.7 & 13.8 & 96.7 \\
\hline Sennar & 42.4 & 41.7 & 16.0 & 105.0 \\
\hline Gedaref & 49.6 & 47.9 & 20.5 & 126.5 \\
\hline Malakal & 78.0 & 69.8 & 23.4 & 176.1 \\
\hline
\end{tabular}

Source: Oliver, 1968 
Rainfall is not only limited in total amount, but also very irregular in time and space. An example (Oliver, 1968) is of two falls on 2 September 1962 in the cotton-growing area of the Gezira, only $6 \mathrm{~km}$ apart, one of which provided $20 \mathrm{~mm}$ and the other $250 \mathrm{~mm}$ of precipitation. Isohyets based on 30 years'observations can, therefore, be considered to be only approximations of what they might be in the very long term. Similarly, figures for average rainfall should also be considered merely indicative of the true figures, especially as they are often established from various sources which themselves differ considerably. Errors of tens of millimetres of the averages quoted are possible, especially in view of the fact that the meteorological stations are widely scattered over the greater part of the country and have little overlap. These problems are reflected in the lines adopted for the isohyets, which often result at least in part from little more than logical deduction.

\section{Climatic trends}

Subsequent to indications of a continuing reduction in crop yields under mechanized agriculture, attention has been directed to long term variations in rainfall. Rainfall data for Gedaref for 19501979, for example, show means and standard deviations of $584+72 \mathrm{~mm}, 582+87 \mathrm{~mm}$ and 615 . $+81 \mathrm{~mm}$ for the successive decades in the overall period (IES, 1985). Within each decade, annual maximum and minimum totals were 714 and $470 \mathrm{~mm}, 743$ and $439 \mathrm{~mm}$ and 775 and $474 \mathrm{~mm}$. This study showed no major changes over the period covered in terms of total rainfall, nor were there any anomalies in its distribution, and it concluded that the fall in yields was due to soil exhaustion consequent on continuous cropping of sorghum without the application of mineral fertilizers. It has, however, since been shown that application of the amounts of nitrogen and phosphorus that are effective in maintaining yields in the subhumid zone do not restore initial production levels on clay 


\section{CLIMATE AND SOILS (CONTINUED)}

soils in the arid zone. This is most likely because "degradation" of these black cracking clay soils (vertisols) includes changes in structure that render them less permeable to infiltration, and also susceptible to both sheet and gully erosion.

In spite of the foregoing, there have been some very dry years during the 1980s (Table 2). As early as 1982 poor rains were noted over much of the country. These continued in subsequent years when precipitation at least $25 \%$ below normal was recorded at many places. In 1984, the worst year ever, rainfall was more than $50 \%$ below average. The effects of lack of rain in 1984 were disastrous on primary production, resulted in large scale divergences in nomadic migratory patterns and caused enormous losses of livestock. The shortfall over several successive years, coupled with overgrazing by a livestock population that had greatly increased prior to the drought, has resulted in long-term changes in the natural vegetation. There are various reports of increasing desertification, of the desert advancing southwards by as much as $100 \mathrm{~km}$, and of widespread degradation of the natural resource base.

The majority of the most recent studies, however, are in general agreement that the precipitation deficit of the exceptional drought of the 1980s is more in the nature of a normal periodic fluctuation than a definitive tendency in the direction of increased aridity. It is not even possible to speak with any certainty of a constant trend towards dryness over the last three milennia, following the humid period which is known to have existed between 7,000 and 4,500 years before the present. Large rainfall oscillations do appear to be normal around the limits of the Sahara. Rainfall in Sudan in the period 1910-1940 was, for example, about $25 \%$ less than during the preceding 30 year period. It was in similar deficit in relation to the succeeding 30 years of 1940-1970, a period which is now often taken as the one of reference. The recent drought has, however, been accompanied by a $16 \%$ reduction in the discharge of the Nile, from which it can be taken that climatic variations have enormous repercussions on the total potential production of Sudan. The exaggerated and increasingly disastrous effects of recent droughts can largely be attributed to the pressure exerted by the human population which has shown a constant increase in recent times.

Table 2- Long-term and annual rainfall data for some selected Sudanese stations

\begin{tabular}{|c|c|c|c|c|c|c|c|c|c|}
\hline \multicolumn{3}{|c|}{$\begin{array}{l}\text { Long-term data } \\
\text { (1951-1980) }\end{array}$} & \multicolumn{7}{|c|}{ Annual data } \\
\hline Location & Mean & Range & 1980 & 1981 & 1982 & 1983 & 1984 & 1985 & 1986 \\
\hline Port Sudan & 23 & $0-101$ & $\mathrm{u}$ & u & 1 & $t$ & 43 & 45 & 66 \\
\hline Abu Hamad & 13 & $0-139$ & $\mathrm{u}$ & $\mathrm{u}$ & $t$ & 3 & $t$ & $\mathrm{t}$ & 9 \\
\hline Dongola & 19 & $0-79$ & $u$ & $\mathrm{u}$ & 7 & 1 & $t$ & $t$ & $t$ \\
\hline Karima & 30 & $0-137$ & $u$ & u & 5 & $t$ & $t$ & $t$ & 21 \\
\hline Atbara & 72 & $0-242$ & 46 & 27 & 18 & 15 & 1 & 33 & 39 \\
\hline Khartoum & 169 & $5-382$ & 96 & u & 103 & 85 & 5 & 39 & 54 \\
\hline El Fasher & 297 & $71-717$ & 191 & $u$ & 110 & 73 & $\underline{71}$ & 172 & 259 \\
\hline Kassala & 324 & $96-488$ & 193 & u & 182 & 250 & $\underline{98}$ & 146 & 305 \\
\hline Wad Medani & 344 & $147-707$ & $u$ & 320 & 200 & 230 & 164 & 339 & 247 \\
\hline El Obeid & 371 & $160-715$ & 330 & 315 & 192 & 352 & 160 & 219 & 376 \\
\hline Kosti & 396 & $96-559$ & 373 & $\mathrm{u}$ & 314 & 267 & $\underline{96}$ & 360 & 280 \\
\hline Nyala & 445 & $188-840$ & 470 & 339 & 271 & 237 & 188 & $u$ & u \\
\hline Sennar & 479 & $175-685$ & 365 & $u$ & 227 & 346 & 209 & 413 & 435 \\
\hline Abu Naama & 576 & $304-774$ & 304 & $u$ & 403 & 353 & 380 & 531 & 447 \\
\hline Gedaref & 580 & $332-1035$ & 571 & 646 & 710 & 473 & 326 & 729 & 574 \\
\hline Kadugli & 687 & $256-1041$ & 256 & $\mathrm{u}$ & 532 & 627 & 401 & 606 & 613 \\
\hline Ed Damazin & 708 & $497-883$ & 510 & 631 & 599 & 685 & 594 & 497 & 567 \\
\hline Juba & 907 & $558-1251$ & $\mid 1078$ & 814 & 1032 & 890 & 832 & 1003 & 926 \\
\hline
\end{tabular}

Notes: $\mathrm{u}=$ unknown; $\mathrm{t}=$ trace 


\section{SOILS}

General studies on Sudanese soils usually describe them in relation to their actual or potential use. The great clay plains resulting from ancient alluvial deposition and the soils of volcanic origin in the Nile basin, of which only $10 \%$ are cultivated intensively and $15 \%$ traditionally, are thus contrasted with the remainder of the country. This basic distinction between the clay plains and the sandy or rocky soils of the rest of the country provides a very simplified classification. It ignores, however, the areas of good cultivatable soils outside the central basin and the pockets of very diverse soils found in the general area of the dark cracking clays and where there are several areas of montmorillonite clays.

Among recent studies which cover the whole of Sudan, one (Purnell and Venema, 1976) identifies 16 soil regions. Each, is described by particular topographical features or by soil associations (Tabe 3). The main areas of soil distribution are also marked on the climatic map as this allows an analysis of soil formation in relation to climate. Some soil regions have, in fact, been delimited in relation to climatic factors and it can be seen that the desert soils approximate to the $75 \mathrm{~mm}$ isohyet at about $17^{\circ} \mathrm{N}$, from the frontier with Chad in the west to Atbara on the Nile in the east. Semi-desert soils and those of the Red Sea correspond, in a similar manner, to the area between the $75 \mathrm{~mm}$ and $200 \mathrm{~mm}$ isohyets. The semi-desert and Red Sea soils differ in respect of the particular topography found at the extreme east of the zone: the shallow Red Sea soils on steep slopes are calcareous and sandy fluvisols and are found in the numerous steep valleys descending from the hills towards the eastern run-off areas.

In areas of higher rainfall a first approximation of soil type can be related to altitude. In the Nuba mountains or uplands it is possible to distinguish the fertile soils of the plateau and the higher slopes, the often poorly drained variable clay plains and the eastern highlands of diverse geological provenance which result in soils ranging from fragile and acid lithosols to accumulations of saline and sodic clays. Jebel Marra in Darfur is characterized by the volcanic nature of the substrate: the soils here become deeper on descending from the summits to the piedmont zone; there are large expanses of volcanic ash and valleys that are partially in-filled by alluvial deposits. Jebel Marra is surrounded by another zone, the Darfur erosive plain, at relatively high altitude, generally undulating and dissected by water courses, where the soils are formed on Precambrian rocks.

The qoz region is typically an extensive peneplained plateau of ancient, once mobile but now fixed, dunes. Qoz soils are poor but free draining, deep and of loamy sand, even along the drainage lines. The qoz is limited to the south by the 10th parallel of latitude north, beyond which is a vast area of laterite, known as the ironstone country, which is continuously capped or has gravel outcrops. The lateritic soils are brown-red in colour, with better structure than the qoz soils, although this is largely determined by their position along the slopes. To the east of the White Nile the latitudes occupied by the qoz in the west comprise the central clay plain with soils that are dark in colour, that are usually alkaline and calcareous, and often reworked due to erosion. Microstudies have enabled zones of exportation and of deposition to be identified; the river banks here 
are subject to strong erosive pressure. The transition to the clays of the south occurs at about $10 \mathrm{~N}$, as for the qoz, but can perhaps be considered to be a little artificial in view of the descriptions that have been made of the two regions. The boundary between the central and southern clays is perhaps better considered to be related to the length of waterlogging under the combined influence of the rainfall and the annual flood. the southern clays are then seen to comprise vast areas of permanent swamp with gley soils and peat underlying them.

The other soil regions are mainly alluvial and differ mainly in relation to their geographical location. The Gash delta is an enormous run on area of loamy clay which is flooded each year for only a short period, due to the flashy nature of the river. Central Kordofan is a gently sloping loamy plain formed from the combined effects of aeolian sediments and colluvium from the Nuba mountains. The plains and meander channels of Southern Darfur and Southern Kordofan are ancient extensions of the southern clay plains which are now partially submerged under imported sand. Southern Darfur and Southern Kordofan include two typical landscape types: the Baqqara comprises alternating low dunes with cracking clays at the contact zone with the qoz; the Raqaba has the dunes replaced by loamy sands or by non-cracking clays. The Baqqara and the Raqaba form an enormous transition zone between the Nile basin and the higher formations to the west and are witness to a more humid geological era in the past. The repetitive nature of the landscape, and the resulting soils, are very typical: an analogous transition zone from the qoz to the central clay plains occurs to the south-west of Kosti. 
Table 3 - Soll regions of Sudan

\begin{tabular}{|c|c|c|c|}
\hline Region & $\begin{array}{r}\text { Area } \\
(\mathrm{km} 2) \\
\end{array}$ & $\begin{array}{l}\text { Rainfall } \\
\text { (mm) }\end{array}$ & Soil characteristics \\
\hline$Y=$ Desert & 668000 & $0-75$ & $\begin{array}{l}\text { Hills, rock, sandsheets, dunes, gravelly } \\
\text { plains; calcareous loamy and clayey } \\
\text { plains }\end{array}$ \\
\hline$X=$ Semi-desert & 387000 & $75-300$ & $\begin{array}{l}\text { Basement complex and Nubian } \\
\text { sandstone plains; deep dark sandy clay } \\
\text { and loam; both with sandsheets: deep } \\
\text { yellowish brown soils with loamy topsoil } \\
\text { over sandy clay or sandy clay loam }\end{array}$ \\
\hline$R=$ Red Sea & 67000 & $25-100$ & $\begin{array}{l}\text { Steep rocky and stony; shallow soils: } \\
\text { valleys; sandy and loamy }\end{array}$ \\
\hline$Q=Q_{0 z}$ & 240000 & $200-900$ & $\begin{array}{l}\text { Deep soils slightly acid to neutral, low } \\
\text { organic matter and nutrient contents, } \\
\text { rapidly drained: brown sand, loamy sand, } \\
\text { sandy loam; deep, well-drained, non } \\
\text { calcareous, acid to neutral alluvions: } \\
\text { yellowish red loamy sand }\end{array}$ \\
\hline $\begin{array}{c}\mathrm{C}=\underset{\text { plain }}{\text { Central clay }} \\
\text { pla }\end{array}$ & 212000 & $200-900$ & $\begin{array}{l}\text { Arid; alkaline and calcareous, sodic, } \\
\text { sometimes saline: semi-arid; alkaline and } \\
\text { calcareous: dry monsoon; slightly acid to } \\
\text { slightly calcareous dark, grey-brown } \\
\text { cracking clay, heavy very dark grey- } \\
\text { brown clay, dark cracking clay }\end{array}$ \\
\hline $\mathrm{G}=\mathrm{Gash}$ delta & 10000 & $100-500$ & $\begin{array}{l}\text { Dark brown to dark greyish brown silty } \\
\text { clay }\end{array}$ \\
\hline $\begin{array}{c}K=\text { Central Kordofan } \\
\text { basin }\end{array}$ & 20000 & $500-800$ & $\begin{array}{l}\text { Flat gently sloping plain, aeolian, alluvial } \\
\text { and colluvial sediments; dark reddish } \\
\text { brown coarse loamy topsoil, dark red fine } \\
\text { loamy subsoil with clay accumulation; } \\
\text { associated acid yellowish red soils }\end{array}$ \\
\hline $\mathrm{J}=$ Jebel Marra & 30000 & $600-1000$ & $\begin{array}{l}\text { Volcanic area; shallow, stony: piedmont; } \\
\text { deep well-drained: ash; loam: flood } \\
\text { plains; coarse-texture with eutric and } \\
\text { calcaric fluvisols }\end{array}$ \\
\hline $\begin{array}{l}\mathrm{D}=\text { Darfur erosive } \\
\text { plain }\end{array}$ & 92000 & $300-800$ & $\begin{array}{l}\text { Undulating, weakly dissected plaíns } \\
\text { surrounding Jebel Marra Basement } \\
\text { complex; rocks: arid, semi-arid; freely } \\
\text { drained reddish brown sandy clays, dark } \\
\text { grey non-cracking clay, deep clay loam, } \\
\text { clay with cover of quartz: strongly } \\
\text { dissected plains; gravel, imperfectly } \\
\text { drained dark grey to dark brown soils }\end{array}$ \\
\hline$N=$ Nuba uplands & 65000 & $500-800$ & $\begin{array}{l}\text { Shallow fertile plateau; deep dark red } \\
\text { soil: clay plains; dark greyish: eastern } \\
\text { plains; brown cracking clay: central } \\
\text { plains; imperfectly drained soils: western } \\
\text { plains; very dark grey nearly black pellic } \\
\text { vertisols, dark reddish brown clay }\end{array}$ \\
\hline $\mathrm{B}=$ Alluvial plains & 60000 & $500-900$ & $\begin{array}{l}\text { Old alluvial plains, Baqqara repeating } \\
\text { pattern; alternating non-cracking clay and } \\
\text { stabilized sand dunes: Raqaba overflow } \\
\text { plain; dark grey cracking clay, non } \\
\text { cracking clay loam, sandy clay loam }\end{array}$ \\
\hline $\begin{array}{c}S=\text { Southern clay } \\
\text { plains }\end{array}$ & 247000 & $700-900$ & $\begin{array}{l}\text { Highlands, non-flooded; yellowish sands } \\
\text { and loamy sands: intermediate land; dark } \\
\text { grey cracking clays: Tolch; dark grey } \\
\text { cracking clay, high organic matter, } \\
\text { hydromorphic gleysols, non-cracking }\end{array}$ \\
\hline$M=$ Swamps & 40000 & $900-1000$ & $\begin{array}{l}\text { Peaty surface layer of organic matter } \\
\text { mixed with clay overlaying gleyed, clayey } \\
\text { subsoils; dystric or eutric histosols, humic } \\
\text { gleysols and eutric gleysols }\end{array}$ \\
\hline I = Ironstone country & 237000 & $900-1300$ & $\begin{array}{l}\text { Catenary toposequence on reddish brown } \\
\text { soils with solid or fragmented iron pan: } \\
\text { plateau; sandy loam: dissected plateau } \\
\text { and jebels; sandy clay loam; transition } \\
\text { zone; colluvial } \\
\text { sandy loam to sandy clay, skeletal, } \\
\text { hydromorphic }\end{array}$ \\
\hline $\begin{array}{c}E=\begin{array}{c}\text { Eastern uplands } \\
\text { and plains }\end{array}\end{array}$ & 105000 & $1000-1600$ & $\begin{array}{l}\text { Variable Basement complex; rocks and } \\
\text { lava: mountain area; medium and fine, } \\
\text { red or brown, acid clay and loam: } \\
\text { piedmont; variable lithosols and nitosols: } \\
\text { plains; grey cracking sodic and saline } \\
\text { clay }\end{array}$ \\
\hline$F=$ Green belt & 25000 & \pm 1400 & $\begin{array}{l}\text { Deep red, variable clay; shallow skeletal } \\
\text { hydromorphic }\end{array}$ \\
\hline
\end{tabular}


Adams M.E., Hales J. - Desertification 3. Sudan the eternal desert. Geogrl. Mag., 1977, 49 (12) : 760-763.

Awadulla S.A. - Potential evapotranspiration over the Sudan: an application of Penman's model over a dense spatial pattern.

Khartoum, Sudan Meteorological Service. 1983. (Sudan Meteorological Service (Scientific Note n_3).

Berry L. - Some notes on the relationships between geomorphology and soils in the Central Sudan. I. Cu. congress, Liverpool: 1964.

Bhalotra Y.P.R. - Meteorology of Sudan.

Khartoum, Sudan Meteorological Service, 1963. (Sudan Meteorological Service Memoir n_6).

El Tom M.A. - A statistical analysis of the rainfall over the Sudan.

Geogrl. J., 1969, 135 : 378-387.

EI Tom M.A. - The reliability of rainfall over the Sudan.

Geografiska Ann. 1972, $\underline{54}$ : 28-31.

FAO/UNDP - Semi-detailed soil survey of parts of the central clay plain, Dinder-Kenana, GeziraManagil, Gash and Tokar Deltas. Rome, FAO, 1970.

FAO/UNESCO - Soil map of the world, at a scale of 1:5000 000. Vol. 1 Legend and Sheet VI-2 (1973) covering the Sudan. Paris, UNESCO Press, 1974.

Griffiths J.F.s Soliman K.H. - The northern desert (Sahara). In: GRIFFITHS J.F., ed. - World survey of climatology. Climates of Africa.

Amsterdam, Elsevier. 1972. Vol. 10. P. 55-131.

Hare F.K. - Connections between climate and desertification.

Environmental Conservation, 1977, 4 (2) : 81-90.

Hulme M. - Rainfall variability and consequential hydrological changes in central Sudan. Ph. D. Thesis. University of Wales, 1985. (Unpublished).

Hulme M. - Secular changes in wet season structure in central Sudan.

J. arid Environ, 1987, 13 : 31-46.

Jackson J.K. - Changes in the climate and vegetation of the Sudan.

Sudan Notes Rec, 1957, 38 : 47-66.

Jefferson J.H.K. - Soil conservation in the Sudan. Khartoum, Ministry of Agriculture, 1956.

Jewitt T.N. - Soils of the Sudan. Ministry of Agriculture Rep. 1954. (Unpublished).

Nicholson S.E. - Sub-Saharan rainfall in the years 1976-80: evidence of continued drought. Monthly Weather Rev. 1983, 111: 1646-1654.

Parry D.E., Wickens G.E. - The qozes of Southern Darfur. Sudan Republic.

Geogrl J., 1981, 147 : 307-320.

Trilsbach A., Hulme M. - Recent rainfall changes in central Sudan and their physical and human implications.

Trans. Inst. Br. Geogr., 1984, New Series, 9 : 280-298.

Walsh R.P.D., Lawler D.M. - Rainfall seasonality: description, spatial patterns and change through time.

Weather, 1981, $\underline{36}: 201-208$.

Warren A. - Dune trends and their implications in the central Sudan.

Z. Geomorph., 1970, 10 : 154-180.

White L.P. - Land and water survey of the Jebel Marra area. Reconnaissance and semi-detailed soil survey. Rome, FAO, 1966. (FAO LA: SF/SUD-17).

Wickens G.E. - Changes in the climate and vegetation of the Sudan since $20000 \mathrm{BP}$.

Boissiera. 1975, $\underline{24}$ : 43-65.

Williams M.A.J., Adamson D. - The physiography of the central Sudan.

Geogrl. J., 1973, 139 : 498-503.

Worral G. - A brief account of the soils of the Sudan.

African Soils, 1961, $\underline{6}: 53-81$.

Zahran A.M.B. - Sudan rainfall variability and tropospheric circulation M.A. Thesis, University of Khartoum, 1979. (Unpublished). 


\section{FEED RESOURCES}

\section{A. DARAG FADL EL MOULAH}

Darag A., El Moulah Fald, De Zborowski Isolde. 1993. Feed resources. In : Livestock production and sahelian rangelands potential: Republic of Sudan = Élevage et potentialités pastorales sahéliennes : République du Soudan. Darag A., Lamarque Georges. CIRAD-IEMVT - FRA. Wageningen : CTA-CIRAD-IEMVT, 19-20. ISBN 2-87614-088-8

The feed value of the open range is related to its diversity in time and space. Each vegetation formation develops during the course of a more or less long growing season, during which quantity increases towards a maximum biomass subsequently to become poorer in quality and quantity while at the same time being subject to attack by animals. Changes are quantitative, whith an annual cycle that is closely related to the rainfall but also to the number and type of animal that is making use of it. Changes are in addition qualitative, the plants being more or less capable of providing the nutritional requirements of the animals depending on their phase in the developmental cycle. Some plants are preferred by cattle, some by camels, and others by sheep or goats, each of which makes a selection of those plants best suited to its needs.

Data from the Sudan on the amount of feed and its nutritional value in each of the vegetative formations are relatively rare. Data are available for small areas only and have not been treated in a manner that would provide an estimate of the overall national feed situation. This present synthesis therefore draws on experience and information from other dry tropical countries and from general figures on nutritional values in order that a comprehensive picture of Sudan's feed resources can be presented. The main sources of information are the data available in the manifold publications on the Sahelian zone of the CIRAD/EMVT. This will supply the users of this atlas with useful data on the management of range resources. It needs to be borne in mind, however, that these figures are only indicative and may vary very much in relation to local conditions.

\section{Feed quality}

Most data on the Sudan use the figure for Total Digestible Nutrients (TDN) as the expression of feed value. The basic calculation assumes a feed of $95 \%$ dry matter with the TDN being equivalent to $31,4 \%$ of the dry matter and an annual feed requirement of $1044 \mathrm{~kg}$ of TDN per cattle TLU. This method only takes into account the energy requirements and provides no information on the protein needs of the animals. In addition no account is taken of the seasonal variation in feed value which allows very high levels of animal production in the rains but induces great physiological stress during the dry season. It is thus evident that an analysis of the annual feed situation needs a very much more detailed treatment.

\section{Animal needs}

Energy and protein requirements will be dealt with separately. Energy is expressed as Feed Units (FU), equivalent to that of $1 \mathrm{~kg}$ of barley and are related to TDN in the ratio of the net energy provided by $1 \mathrm{~kg}$ feed to that of $1883 \mathrm{cal}$ present in $1 \mathrm{~kg}$ of barley, that is:

Feed units $(F U)=3.65$ TDN $(\mathrm{g} / \mathrm{kg})-\mathrm{DM}(\mathrm{g} / \mathrm{kg}) / 1883$.

The daily feed requirements of one TLU of $250 \mathrm{~kg}$ are about $2.3 \mathrm{FU}$ for maintenance, 0.6 FU for a daily walking distance of $10 \mathrm{~km}$ plus those required for production equivalent to $0.4 \mathrm{FU}$ per $\mathrm{kg}$ milk and 2.4 FU per $\mathrm{kg}$ live weight gain. An animal producing $1.5 \mathrm{~kg}$ of milk or gaining $250 \mathrm{~g}$ per day would thus require $3.5 \mathrm{FU}$ per day or it would lose weight.

At least $150 \mathrm{~g}$ of digestible protein are needed for maintenance, $500 \mathrm{~g}$ per $\mathrm{kg}$ of live weight increase and $60 \mathrm{~g}$ per litre of milk produced. The ratio DP:FU provides a good indication of a feed's value. The best ratio for cattle is 110 , no production is possible if it is below $80-90$ and it should not be less than 50: small ruminants are generally more demanding with the optimum ratio being 130-140 and a minimum of $70-80$. Camels probably require a ratio similar to that of goats and sheep.

Another method of calculating the feed requirements of an animal is to calculate the minimum values of the feed which will provide them with an adequate amount of nutrients, in the knowledge that a TLU can eat about $6 \mathrm{~kg}$ of dry matter per day. Thus each $\mathrm{kg}$ of feed must contain at least 0.5 FU and $25 \mathrm{~g}$ digestible protein for maintenance alone and $0.6 \mathrm{FU}$ and $45 \mathrm{~g}$ DP are required even at minimum production levels. This paragraph does not pretend to be a treatise on animal nutrition but the figures quoted need to be borne in mind when attempting to evaluate the feed resources of the Sudan. 


\section{Grass quality}

The quality of different areas of rangeland varies enormously, as for example, in the hyper-arid north where the grasses are mostly annuals to the more humid south where an increasing proportion of perennials are present.

A typical example of an annual grass is provided by Aristida. At the beginning of the growing season the plants contain a lot of water and only $25 \%$ dry matter but that dry matter is high in protein which may be more than $10 \%$ : with a feed value of $0.6 \mathrm{FU}$ and a DP/FU ratio greater than 100 this provides a feed of very high quality. Its quality diminishes, however, as the plant starts to flower, often after only 40-50 days of growth, and at this stage the grass is not capable of providing an animal's minimum feed requirements. By the beginning of the dry season Aristida contains no digestible protein at all and is also low in energy.

In the Sahel or semi-arid zone the development cycle of annual grasses is slower, the energy value of older plants (while still being poor) is better than of those in the very dry areas but there is still a lack of protein.

Perennial grasses such as Panicum turgidum and Andropogon gayanus are able to provide adequate amounts of energy over longer periods but they also lack protein.

In general grasses are high in energy and adequate in protein for only limited periods of the year and at early stages in their development cycle (Table 1). For most of the year animals can not obtain an adequate diet from grasses alone, even if they select only the best that it is available.

\section{Herb quality}

Pastoralists and livestock owners are fully aware of the feed value of the non-grass components of the field layer. For example, cattle refuse to eat Blepharis linarifolia when it shoots to its spiny flowering heads but it is a favourite feed for camels and sheep at this stage when the seeds are in the heads. While the plant does not usually form an extensive single-species stand, and Harrison and Jackson (1958) noted that herds often had to move long distances in search of it, it is a valuable feed constituent which maintains a protein content of $25-50 \mathrm{~g} \mathrm{DP} / \mathrm{kg} \mathrm{DM}$ throughout the long dry season when feed quality is generally poor.

Leguminous species are also a good source of protein.In Kordofan, pastures that contain Cenchrus. Indigofera oblongifolia. Rhynchosia and Tephrosia are used throughout the year, even though sheep usually avoid grazing areas containing Cenchrus as the seeds stick in their fleece (Baumer, 1979). Indigofera and Tephrosia are little grazed during the rainy season but become extremely important sources of protein in the dry season, having a feed value of $0.6 \mathrm{FU}$ and 30-70 g DP in each kilogramme of dry matter. The very widespread legume, Zornia glochidiata, particularly common on sands in run-on areas and slight depressions where water collects in the rains has a feed value of $0.70 \mathrm{FU}$ and more than $100 \mathrm{~g} \mathrm{DP} / \mathrm{kg}$ in the green state and still contains more than $25 \mathrm{~g}$ DP in the dry season even though at this time it has lost most of its leaves.

Some other examples of herbs that have good protein contents (Table 1) include Borreria spp.. Tribulus which is a recumbent plant with a very short cycle and contains $10-15 \% \mathrm{DP}$, the cucurbits such as Citrullus, and Commelina $(140 \mathrm{~g} \mathrm{DP} / \mathrm{kg})$ and Trianthema $(200 \mathrm{~g} \mathrm{DP} / \mathrm{kg})$. The "gizu" is a very good example of a protein-rich pasture, this fact in large part explaining its excellent value as a feed resource. 
Table 1 - Proximate composition and feed value of some common Sudan grasses, herbs and crop residues at various stages of growth

\begin{tabular}{|c|c|c|c|c|c|c|c|}
\hline \multirow{2}{*}{$\begin{array}{l}\text { Plant type and } \\
\text { species }\end{array}$} & \multirow[b]{2}{*}{ Growth stage } & \multirow{2}{*}{$\begin{array}{l}\text { Dry } \\
\text { matter } \\
(\%)\end{array}$} & \multicolumn{5}{|c|}{ Feed component ( $\%$ of DM) } \\
\hline & & & CP & Fibre & Ash & DP & $\begin{array}{l}\text { Feed } \\
\text { Units }\end{array}$ \\
\hline \multicolumn{8}{|l|}{ Grasses } \\
\hline \multirow[t]{6}{*}{ Andropogon gayanus } & early growth & 28.0 & 11.0 & 31.0 & 8. 1 & 6.5 & 0.67 \\
\hline & flowering stage & 27.4 & 8.6 & 31.8 & 8.8 & 4.1 & 0.64 \\
\hline & regrowth, 2 months & 29.0 & 4.2 & 39.7 & 5.8 & 0.1 & 0.44 \\
\hline & regrowth, 1 month & 33.4 & 11.0 & 30.5 & 8.3 & 6.5 & 0.68 \\
\hline & seeding stage & 49.1 & 3.5 & 36.8 & 5.2 & 0.0 & 0.55 \\
\hline & dry leaves & 90.6 & 2.4 & 38.5 & 6.9 & 0.0 & 0.47 \\
\hline Aristida & early growth & 25.8 & 10.8 & 33.5 & 9.8 & 6.1 & 0.58 \\
\hline \multirow[t]{3}{*}{ adscensionis } & flowering stage & 32.1 & 7.4 & 35.4 & 9.1 & 2.9 & 0.53 \\
\hline & seeding stage (dry) & 87.3 & 5.2 & 39.5 & 9.6 & 0.7 & 0.38 \\
\hline & dry season & 93.7 & 2.1 & 45.6 & 8.0 & 0.0 & 0.18 \\
\hline Aristida & early growth & 27.1 & 8.7 & 35.3 & 10.1 & 4.3 & 0.51 \\
\hline \multirow{3}{*}{ funiculata } & flowering stage & 51.3 & 4.7 & 38.5 & 7.9 & 0.2 & 0.46 \\
\hline & seeding stage & 60.0 & 3.9 & 39.5 & 6.8 & 0.0 & 0.44 \\
\hline & dry season & 92.8 & 2.5 & 42.6 & 9.0 & 0.0 & 0.29 \\
\hline Aristida & early growth & 22.6 & 13.3 & 31.1 & 9.1 & 8.8 & 0.66 \\
\hline \multirow[t]{3}{*}{ mutabilis } & flowering stage & 32.5 & 7.2 & 35.6 & 8.0 & 2.7 & 0.54 \\
\hline & seeding stage & 58.3 & 4.5 & 39.3 & 6.8 & 0.0 & 0.44 \\
\hline & dry season & 93.6 & 3.2 & 41.7 & 6.6 & 0.0 & 0.35 \\
\hline Cenchrus & early growth & 23.0 & 15.0 & 30.3 & 11.8 & 11.5 & 0.63 \\
\hline biflorus & flowering stage & 25.1 & 8.8 & 33.2 & 10.9 & 4.3 & 0.57 \\
\hline & seeding stage & 39.2 & 5.4 & 38.8 & 9.2 & 0.9 & 0.41 \\
\hline & dry season & 87.4 & 3.5 & 39.2 & 9.9 & 0.0 & 0.39 \\
\hline Dactyloctenium & early growth & 28.6 & 9.4 & 29.4 & 7.0 & 4.9 & 0.75 \\
\hline aegyptiacum & flowering stage & 26.7 & 7.8 & 32.3 & 8.8 & 3.3 & 0.63 \\
\hline & seeding stage & 39.9 & 6.7 & 34. 9 & 7.1 & 2.2 & 0.58 \\
\hline Eragrostis & pre-flowering & 45.6 & 6.9 & 34.5 & 4.7 & 2.4 & 0.65 \\
\hline remula & seeding stage & 60.2 & 3.8 & 37.0 & 3.6 & 0.0 & 0.59 \\
\hline & dry season & 94.1 & 1.2 & 41.3 & 5.5 & 0.0 & 0.41 \\
\hline Hyparrhenia rufa & early growth & 27.5 & 10.6 & 30.4 & 7.0 & 6.0 & 0.63 \\
\hline & regrowth, 2 months & 39.0 & 7.6 & 31.9 & 14.5 & 3.1 & 0.55 \\
\hline & full development & 54.0 & 2.7 & 35.4 & 11.1 & 0.0 & 0.49 \\
\hline Panicum turgidum & flowering stage & 34.1 & 9.7 & 31.7 & 7.8 & 5.2 & 0.67 \\
\hline & seeding stage & 33.8 & 6.0 & 35.4 & 7.2 & 1.5 & 0.57 \\
\hline & dry spikes & 54.7 & 2.7 & 38.5 & 7.7 & 0.0 & 0.46 \\
\hline & dry leaves & 87.2 & 3.1 & 39.4 & 6.1 & 0.0 & 0.45 \\
\hline Schoenefeldia & early growth & 26.2 & 8.7 & 34.9 & 8.0 & 4.2 & 0.56 \\
\hline gracilis & flowering stage & 33.2 & 6.3 & 36.0 & 8.9 & 1.8 & 0.52 \\
\hline & seeding stage & 50.5 & 4.1 & 37.3 & 7.6 & 0.0 & 0.49 \\
\hline & dry season & 92.7 & 1.6 & 41.9 & 7.8 & 0.0 & 0.32 \\
\hline Herbs & & & & & & & \\
\hline Blepharis & early growth & 18.7 & 22.1 & 14.7 & 13.9 & 17.8 & \\
\hline linarifolia & flowering stage & 30.4 & 9.4 & 18.9 & 11.2 & 4.9 & \\
\hline & seeding stage & 73.8 & 6.9 & 22.4 & 5.9 & 2.4 & \\
\hline & dry season & 94.7 & 7.3 & 25.7 & 13.5 & 2.8 & \\
\hline Borreria spp. & flowering stage & 21.3 & 8.4 & 27.0 & 7.7 & 3.9 & \\
\hline & seeding stage & 36.9 & 7.1 & 27.6 & 10.8 & 2.6 & \\
\hline & dry spikes & 86.6 & 8.3 & 26.8 & 10.5 & 3.8 & \\
\hline Citrullus & flowering stage & 15.4 & 6.6 & 13.7 & 21.6 & 12.1 & \\
\hline colocynthis & with fruits & 20.3 & 14.4 & 21.9 & 12.6 & 9.9 & \\
\hline Cyperus & early growth & 25.3 & 11.3 & 27.1 & 8.7 & 6.8 & \\
\hline conglomeratus & flowering stage & 34.9 & 5.2 & 30.8 & 8.2 & 0.7 & \\
\hline & dry season & 94.0 & 3.5 & 35.1 & 6.8 & 0.0 & \\
\hline Indigofera spp. & early growth & 21.6 & 17.3 & 17.7 & 10.5 & 12.8 & 0.85 \\
\hline & flowering stage & 30.2 & 10.4 & 37.0 & 13.3 & 5.9 & 0.43 \\
\hline & seeding stage & 36.6 & 11.1. & 26.1 & 10.7 & 6.6 & 0.71 \\
\hline & dry season & 91.2 & 6.7 & 28.3 & 11.6 & 2.2 & 0.76 \\
\hline Tribulus & early growth & 23.4 & 18.5 & 22.5 & 14.1 & 14.0 & \\
\hline terrestris & flowering stage & 25.6 & 15.6 & 26.3 & 19.3 & 11.1 & \\
\hline Zornia & early growth & 19.1 & 18.7 & 24.9 & 9.7 & 14.2 & 0.74 \\
\hline glochidiata & flowering stage & 32.1 & 16.0 & 27.7 & 6.6 & 1.5 & 0.74 \\
\hline & seeding stage & 33.2 & 13.4 & 29.7 & 7.1 & 8.9 & 0.69 \\
\hline & early dry season & 93.6 & 13.2 & 30.2 & 9.6 & 8.7 & 0.65 \\
\hline & late dry season & 95.5 & 6.9 & 37.9 & 3.9 & 2.4 & 0.53 \\
\hline Crop residues & & & & & & & \\
\hline Millet & stalks & 85.0 & 5.6 & 41.4 & 7.4 & 1.9 & 0.36 \\
\hline Rice & stalks & 92.3 & 3.2 & 38.0 & 17.7 & 0.0 & 0.42 \\
\hline Sorghum & stalks & 77.4 & 3.9 & 40.3 & 9.0 & 0.0 & 0.30 \\
\hline Maize & leaves & 85.9 & 3.8 & 38.6 & 4.3 & 1.4 & 0.27 \\
\hline Groundnuts & leaves & 89.8 & 8.6 & 43.3 & 9.3 & 3.4 & 0.30 \\
\hline Sugar cane & eaves & 68.0 & 2.7 & 39.8 & 5.4 & 0.0 & 0.44 \\
\hline
\end{tabular}


Even though many herbaceous plants contribute to increasing the feed value of the feed layer when grasses have dried out they are not present in sufficient quantity to be capable in themselves of providing an adequate ration. Most protein is thus obtained from browsing trees and shrubs, including their green or dry leaves, flowers, fruits and young twigs. All the domestic species, but particularly camels and goats, eat some browse, the proportion increasing as the quality of the field layer diminishes.

An indication of the feed value of browse can be had by looking at the composition of some Acacia species. The green leaves contain $110-130 \mathrm{~g} \mathrm{DP} / \mathrm{kg}$ DM and they also have an energy value of 0.8-0.9 FU. Even dry leaves that have fallen to the ground have a protein content of some $6 \%$ and the small new shoots have a similar value. Herdsment often reserve the pods of leguminous trees for use by lactating females, a rational practice when it is realized that the seeds contain $20 \% \mathrm{DP}$. Branches are often cut from trees (particularly from Acacia seyal on waterlogged soils) to make this kind of feed more readily available to animals. Overuse of this technique during the recent drought years has unfortunately contributed to the disappearance of many trees, even though these are basic to animal survival in many areas.

Leguminous species are not, however, the only trees of good feed value (Table 2). The Capparidaceae are also important in this respect and are actively sought out: they are fairly resistant to direct browsing and when cut for feed they assume the characteristic appearance of a thight ball of dense twigs. Almost all the Combretaceae are also eaten willingly and it would in fact be true to say that almost no tree is totally ignored. Even Calotropis procera, supposedly not eaten, will be sought out by cattle in extreme cases of feed shortage.

Most woody species contain more than $50 \mathrm{~g} \mathrm{DP} / \mathrm{kg}$ DM but the energy values generally quoted (Table 2) should be treated with some circumspection as digestibility often interferes with proper absorption. Tannins and phenolic compounds often reduce digestibility but there is still a lot of work to be done before firm statements can be made about the real effects of these compounds. Within the context of a mixed and complex feed supply, however, the value of browse has to be considered as being very high.

Table 2 - Proximate composition and feed value of some common Sudan trees and shrubs at - various stages of growth

\begin{tabular}{|c|c|c|c|c|c|c|c|}
\hline \multirow{2}{*}{ Species } & \multirow{2}{*}{ Growth stage } & \multirow{2}{*}{$\begin{array}{c}\text { Dry } \\
\text { matter } \\
(\%)\end{array}$} & \multicolumn{5}{|c|}{ Feed component ( $\%$ of DM) } \\
\hline & & & $\mathrm{CP}$ & Fibre & Ash & DP & $\begin{array}{l}\text { Feed } \\
\text { Units }\end{array}$ \\
\hline \multirow[t]{4}{*}{ Acacia nilotica } & green leaves & 37.8 & 16.7 & 10.8 & 7.1 & 12.2 & \\
\hline & dry leaves & 90.1 & 11.2 & 12.4 & 6.2 & 6.7 & 0.84 \\
\hline & green pods & 40.4 & 11.2 & 13.9 & 4.4. & 6.7 & \\
\hline & dry pods & 90.8 & 9.8 & 18.4 & 4.5 & 5.3 & \\
\hline \multirow[t]{3}{*}{ Acacia raddiana } & green leaves & 37.9 & 17.8 & 17.0 & 7.4 & 13.3 & 0.94 \\
\hline & young twigs & 32.5 & $16 . .2$ & 28.2 & 6.0 & 11.7 & 0.74 \\
\hline & green pods & 31.0 & 14.1 & 21.8 & 6.8 & 9.6 & \\
\hline \multirow[t]{3}{*}{ Acacia senegal } & green leaves & 43.3 & 16.0 & 12.1 & 6.6 & 11.5 & 0.85 \\
\hline & dry leaves & 88.4 & 18.2 & 11.2 & 8.4 & 13.7 & 0.71 \\
\hline & dry pods & 91.9 & 24.2 & 22.8 & 7.3 & 19.7 & \\
\hline Balanites & green leaves & 44.2 & 12.9 & 13.9 & 15.7 & 8.4 & \\
\hline \multirow[t]{2}{*}{ aegyptiaca } & twigs and leaves & 50.0 & 11.9 & 17.3 & 14.0 & 7.4 & \\
\hline & fruits & 68.5 & 11.2 & 10.1 & 8.1 & & \\
\hline \multirow[t]{2}{*}{ Cadaba spp. } & green leaves & 40.3 & 22.5 & 13.1 & 19.7 & 18.0 & \\
\hline & leafy twigs & 54.8 & 9.1 & 24.6 & 9.8 & 4.6 & 0.68 \\
\hline Combretum & green leaves & 32.0 & 13.0 & 12.2 & 6.5 & 8.5 & \\
\hline \multirow{2}{*}{ glutinosum } & older leaves & 52.2 & 8.6 & 18.7 & 6.1 & 4.1 & \\
\hline & dry leaves & 92.2 & 11.4 & 27.2 & 7.2 & 6.9 & \\
\hline \multirow[t]{3}{*}{ Acacia albida } & green leaves & 30.7 & 17.8 & 17.5 & 6.4 & 10.3 & \\
\hline & dry leaves & 92.8 & 11.7 & 21.4 & 4.1 & 7.2 & 0.88 \\
\hline & pods & 89.4 & 11.8 & 19.6 & 4.0 & 7.3 & \\
\hline Guiera & dry leaves & 95.5 & 9.3 & 22.0 & 6.2 & 4.8 & \\
\hline senegalensis & young twigs & 37.9 & 28.8 & 15.4 & 5.0 & 24.3 & \\
\hline Leptadenia & green leaves & 21.0 & 13.9 & 14.7 & 15.6 & 9.4 & \\
\hline pyrotechnica & tiwgs & 31.6 & 8.6 & 42.3 & 7.2 & 4.1 & \\
\hline Maerua & green leaves & 44.0 & 22.5 & 8.4 & 18.9 & 18.0 & \\
\hline crassifolia & leafy twigs & 41.7 & 23.6 & 10.9 & 16.5 & 19.1 & \\
\hline \multirow[t]{3}{*}{ Pterocarpus spp. } & young leaves & 28.4 & 21.2 & 17.0 & 7.7 & 16.7 & 0.88 \\
\hline & older leaves & 37.5 & 12.1 & 27.3 & 6.7 & 7.6 & 0.74 \\
\hline & dry leaves & 90.5 & 10.3 & 31.5 & 7.4 & 5.8 & 0.51 \\
\hline \multirow{4}{*}{$\begin{array}{l}\text { Sclerocarya } \\
\text { birrea } \\
\text { Tamarindus indica }\end{array}$} & young leaves & 25.0 & 10.5 & 13.4 & 10.7 & 6.0 & \\
\hline & dry leaves & 95.9 & 5.7 & 20.2 & 16.5 & 1.2 & \\
\hline & green leaves & 32.1 & 11.4 & 17.8 & 7.4 & 6.9 & 0.67 \\
\hline & pods & 92.5 & 8.4 & 12.6 & 4.4 & 3.9 & \\
\hline \multirow{2}{*}{$\begin{array}{l}\text { Ziziphus } \\
\text { mauritiana }\end{array}$} & young leaves & 33.0 & 19.4 & 11.2 & 8.4 & 14.9 & \\
\hline & leafy twigs & 92.6 & 12.2 & 20.6 & 7.9 & 7.7 & \\
\hline
\end{tabular}


FEED RESOURCES (CONTINUED)

PRIMARY PRODUCTIVITY AND FEED RESOURCES

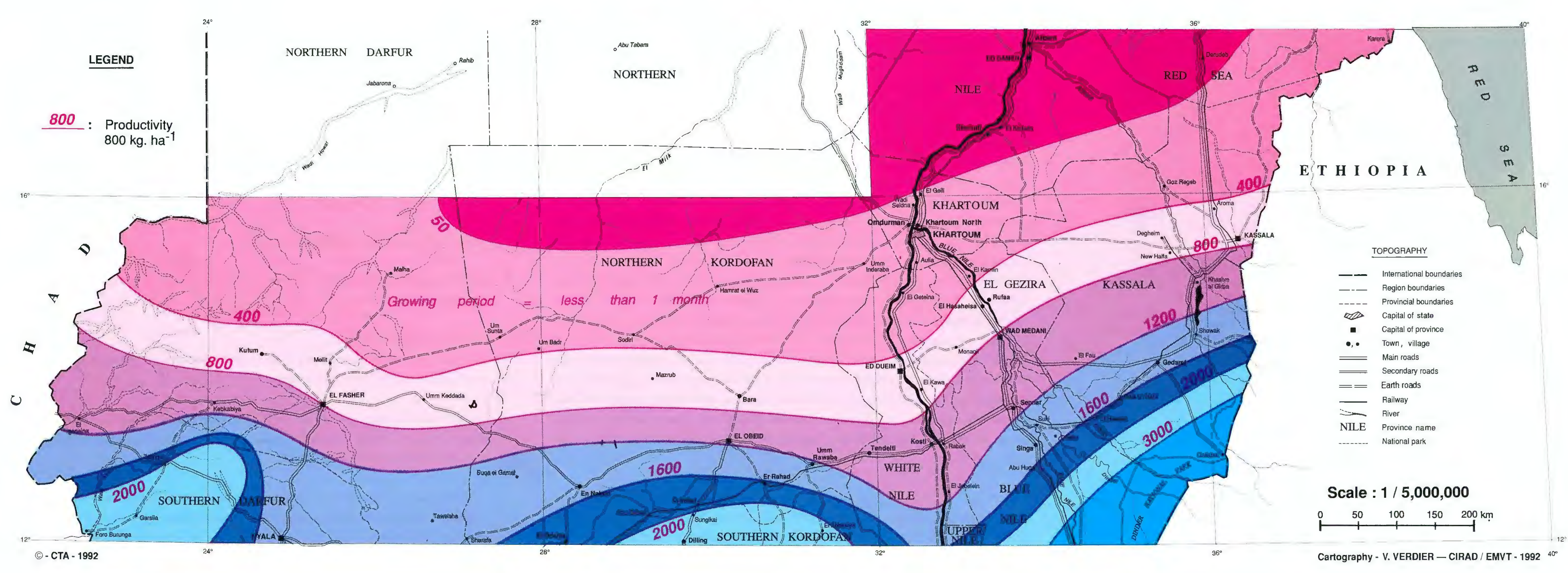




\section{Crop residues}

Crop residues provide another source of animal feed. The livestock of mixed farmers, and occasionally of pastoralists, have access to crop residues after the harvest. Feed values are usually low, of the order of $0.3 \mathrm{FU} / \mathrm{kg} \mathrm{DM}$, and the residues also usually contain little or no digestible protein. The exception to the general rule is provided by the haulms of groundnuts, which have a generally higher feed value, advantage being taken of this to sell therh, especially in and around the larger towns. When efforts to conserve crop residues are made they are rarely stacked or stored properly and further losses in feed value occur, such that they are only of similar nutritive value as dry grasses when they are finally fed.

In irrigated areas there is some possibility of better nutrition, especially of protein, from the regrowth of weeds and crops in the fields and from the growth on canal banks. Even here, however, as well as in dryland farming areas, it is necessary to provide some concentrate feed or some agro-industrial by products, to ensure a satisfactory ration.

\section{Minerals}

Theoretical requirements for the two major elements are met when the feed resource contains more than $0.3 \%$ of calcium and $0.2 \%$ of phosphorus. These requirements are usually met for calcium as grasses contain $0.26-0.50 \%$ when young and about $0.35 \%$ at later stages. Phosphorus contents of herbaceous species (including non-grasses), on the other hand, are usually of the order of $0.10-0.20 \%$ in the early growth stages and are reduced to less than $0.1 \%$ at later stages. Phosphorus deficiencies are unfortunately not overcome by browse as these species also usually contain only $0.07-0.15 \%$ of the element.

Crop residues are low in both calcium and phosphorus but some by-products (such as oil seed cakes) and grains have higher levels of phosphorus of $0.3-0.6 \%$ or, as in the case of cotton seed cake, even up to $1.2 \%$.

In general it can be considered that phosphorus nutrition is inadequate on most pastures and that in many areas minor and trace elements will also be deficient.

\section{Feed quantity}

It is difficult to estimate the productivity of arid tropical rangelands for several reasons. First of all, as already stated, the growing period is very short and does not allow of several measurements. Interannual variations are very large in relation to the variations in rainfall. In addition, the problem is accentuated for trees and shrubs whose productivity is notoriously difficult to estimate or measure. In the particular case of the Sudan, the droughts between 1974 and 1984 have also made it difficult to apply regular formulae for estimating production of vegetation types, as the composition of some of these has changed over this period. This section therefore only attempts to indicate some orders of magnitude of range production in the Sudan, based on a knowledge of various production factors and how they are affected by other factors. 


\section{Net primary production}

Most available data relate to the maximum standing crop biomass either at the end of the rainy season or at the beginning of the dry season. This figure in itself results from that which has been produced during the growth period, less that which has already been eaten (not only by domestic stock but by such other consumers as rodents and insects) or lost and is thus lower than actual production. Domestic animals, during the course of the rainy season, thus have available to them more feed than is apparent at the end of it, even on reserved areas. If, on the other hand, they graze an area later there is only a (usually unknown) proportion of the original production left to them.

Several methods are available for the calculation of primary production. The simplest is to consider the rainfall as the basic factor in vegetative growth and to calculate productivity as a direct function of total rainfall: several methods are available to do this and these usually estimate primary production at $400+100 \mathrm{~kg} \mathrm{DM} / \mathrm{ha}$ at $200 \mathrm{~mm}$ of rain and at $1500+500 \mathrm{~kg}$ at $400 \mathrm{~mm}$ of rain per year although differences exist in productivity at any given rainfall level for various soil types. Another method is to use the growth period in place of the actual amount of rainfall as this takes into account the properties of the soil and its moisture content: for the same rainfall, therefore, production can be calculated for sand or clay soils and for topographic situation. The second method is obviously more useful for the Sudan in this study in view of the approach that has been adopted in defining the agroecological zones.

Suggested values of daily production in relation to soil factors, including fertility and depth, expressed as kg DM per ha are 5-15 for lithosols or soils low in organic matter, 10-25 for more-orless developed sandy soils, and 20-35 for alluvial and clay soils and loams with high baseexchange capacities.

\section{Interannual variation}

Using the method of calculation just described variations in production are expressed in relation to the growing period. Some examples will serve to illustrate the point.

The growing season at Kassala extends from nought to three months. Zero growth is expected only five times every 100 years. The modal growing period is of one month, this occurring in 35 of 
every 100 years althought the month may be August (probability $=0.18$ ), July $(p=0.10)$, September $(p=0.03)$, or a split period $(p=0.04)$. The probability of a two month growing period (July-August or August-September) is 0.31 , that of a period extending from June-August or JulySeptember being 0.29 . From the foregoing it is possible to deduce a weighted average growing season of 55 days.

At Gedaref there is often a four month growing period ( $p=0.63$ ), sometimes one of three months $(p=0.27)$ and occasionally one of five $(p=0.08)$ or even of six $(p=0.03)$ months. The average growing period at Gedaref is thus 117 days. At Er Roseires the growing period is usually six months $(p=0.43)$, sometimes seven $(p=0.19)$ and sometimes five $(p=0.34)$ to provide an overall average growing period of 170 days.

The relative variation in the growing period at any site is reduced in proportion to the total rainfall received. At Gedaref and Er Roseires the average growing periods have a variance of 40 days, or variabilities of $23 \%$ and $34 \%$, while variability at Kassala is about $90 \%$. The idea of an "average" year does not, therefore, have much meaning where estimations of productivity tend to hide the fact that the situation changes very rapidly from one period to the next.

In spite of the reservations, however, attempts have been made to calculate growing periods for all of the mapped ecozones and to apply daily rates of production to these in order to be able to establish total production on the map opposite and to draw lines of equal average forage productivity on it. It has been assumed that the growing period on clays and in the hill areas is shorter by 10 days than it is on sands and that daily production in the hyper-arid zone is $10 \mathrm{~kg}$, in the hill areas is $15 \mathrm{~kg}$, on sands is $18 \mathrm{~kg}$ and on clays is $22 \mathrm{~kg}$.

\section{Production and loss}

The only data available relate to recent floristic changes or to changes resulting from the overuse of the range in the middle 1970s. These indicate, for example, that there has been considerable loss of Panicum turgidum and that Leptadenia pyrotechnica is practically the only plant to have emerged unscathed in Northern Kordofan. Areas mapped in the 1950s (Harrison and Jackson, 1958 ) as being Acacia senegal savanna woodland are now semidesert and Combretum kordofanum is currently found in the southern part of its former distributional range. Dalbergia amara has generally replaced Terminalia brownii in these areas but in some places only Calotropis procera survives. 
A constant feature of recent change has been the gradual replacement of perennial grasses by short cycle annuals. This is a common change in Kordofan, where it occurred fairly early. It was at first attributed to uncontrolled fires (which used to cover $35 \%$ of the area) and to their deleterious effects on the soil through temperature.increases and to reduced infiltration capacity through removal of surface litter, as well as to overgrazing. On soils with unfavourable moisture status it is not now possible for perennials to establish themselves in the short growing period available and only some short season annuals are able to survive and produce.

When one considers, however, that fires are only possible in the savanna woodland areas where there is an adequate biomass of combustible material, it can be seen that fires are of little consequence in the arid and semi-arid areas. Satellite imagery (both NOAA and LANDSAT) shows continuing degradation of the dry rangelands, however, over an area of some $650,000 \mathrm{~km} 2$, or approximately $25 \%$ of Sudan's total area. Continuing degradation is explained by the fact that pastoralists are still making their seasonal migrations, in spite of the improvements in climatic conditions, and have a tendency to travel farther and farther south. The lack of feed availability leads to a high mortality and especially to high levels of morbidity which greatly reduce the secondary productivity of the national herd.

In parallel with the degradation of the rangelands it must be remembered that their area is also being reduced in the arid and semi-arid zones as a consequence of the expansion of cultivated areas. In addition the concentration of pastoral populations in the better-endowed areas, for example in river valleys, and around towns which provide the opportunity of additional feed resources contribute to the general degradation. The expansion of rainfed agriculture, on the "qoz" as well as on the clay plains, means that the chances of the rangelands ever producing at the level they were at 20 years ago, in terms of both quality and quantity, are very poor.

\section{Overall range production}

The percentage of an area available to livestock varies among the ecoclimatic zones defined in this Atlas. Rangelands now hardly represent $50 \%$ of the total area on clay and $70 \%$ of the area on sand in the semi-arid zone, the situation being intermediate in the cultivated hill areas of Darfur. In the arid zone it can be estimated that $10 \%$ of the area on clay, $20 \%$ on sand and $30 \%$ of the highland areas are cultivated or otherwise irrevocably lost to livestock in Darfur. In the Darfur hyper-arid zone almost the whole of the area is still available to livestock, as it is in the north-east of the mapped area.

The large areas of infertile land and those inaccessible because of lack of water have led to the adoption of a conservative estimate of $5 \mathrm{t} D M / \mathrm{km} 2$ in the Red Sea Hills. In the other major ecozones it is estimated that range productivity is $10 \mathrm{t} \mathrm{DM} / \mathrm{km} 2$ in the hyper-arid areas, $40 \mathrm{t}$ in the Northern Darfur hills, $70 \mathrm{t}$ on arid sands, $80 \mathrm{t}$ in the Butana, $160 \mathrm{t}$ in the hilly areas south of $14^{\circ} \mathrm{N}$, 
$180 \mathrm{t}$ on semi-arid sands and $200 \mathrm{t}$ on clay in the southern part of the area. The semi-arid zone produces 29 million tons of feed or $63 \%$ of the total, this being twice as much as that produced in the Sahel zone and 12 times as much as the area north of the $200 \mathrm{~mm}$ isohyet. The semi-arid zone is thus still by far the major area of feed production for Sudan's livestock.

The feed situation based on the calculations in this chapter for that part of the Sudan covered by this Atlas (that is north of $12^{\circ} \mathrm{N}$ ) is given in(Table 3) for each administrative unit. There is good agreement between these figures and those used by the Range ans Pasture Administration (Table 4) which are arrived at by a totally different method of calculation and in spite of differences in the areas allotted to each ecozone in the two methods. The Central Province can be used as an example: the Pasture Administration assigns a nil value to areas accessible to livestock but of poor nutritive value while the calculations for this atlas include them but overall the total estimated production is the same.

Table 3 - Calculated range production by region and ecozone

\begin{tabular}{|c|c|c|c|c|c|}
\hline \multicolumn{6}{|c|}{ Region ('000 $\mathrm{km}^{2}$ ) } \\
\hline Ecozone and soil type & Darfur & Kordofan & $\begin{array}{l}\text { Central } \\
\text { and } \\
\text { Khartoum }\end{array}$ & Eastern & Northern \\
\hline $\begin{array}{l}\text { Semi-arid rangelands } \\
\text { on sand ( } 70 \% \text { of area) } \\
\text { on hills ( } 60 \% \text { of area) } \\
\text { on clay ( } 50 \% \text { of area) }\end{array}$ & $\begin{array}{l}15400 \\
43800\end{array}$ & 44800 & 32500 & 24000 & \\
\hline $\begin{array}{l}\text { Arid rangelands } \\
\text { on clays ( } 90 \% \text { of area) } \\
\text { on hills ( } 70 \% \text { of area) } \\
\text { on sand ( } 80 \% \text { of area) }\end{array}$ & $\begin{array}{l}25200 \\
33600\end{array}$ & 64800 & $\begin{array}{r}34200 \\
4800\end{array}$ & 42300 & \\
\hline $\begin{array}{l}\text { Hyper arid rangelands } \\
\text { (100\% of area) } \\
\text { Red Sea Hills } \\
\text { (100\% of area) }\end{array}$ & 43000 & 90000 & 18000 & $\begin{array}{l}32000 \\
17000\end{array}$ & 59000 \\
\hline $\begin{array}{l}\text { Grass production } \\
\text { mapped area (tonnes } \times 10^{6} \text { ) } \\
\text { mean (tonnes } / \mathrm{km}^{2} \text { ) }\end{array}$ & $\begin{array}{l}13.57 \\
62.82\end{array}$ & $\begin{array}{l}13.50 \\
57.20\end{array}$ & $\begin{array}{r}9.75 \\
76.79\end{array}$ & $\begin{array}{r}8.59 \\
56.65\end{array}$ & $\begin{array}{l}0.59 \\
6.94\end{array}$ \\
\hline
\end{tabular}

Table 4 - Estimated rangeland forage production, 1987 (Range and Pasture Administration)

\begin{tabular}{l|c|c|c}
\hline Region & $\begin{array}{c}\text { Usable rangetand } \\
\left(\text { '000 } \mathrm{km}^{2}\right)\end{array}$ & $\begin{array}{c}\text { Productivity } \\
\text { (tha) }\end{array}$ & $\begin{array}{c}\text { Total production } \\
(\mathbf{t} \times \mathbf{1 0 6})\end{array}$ \\
\hline Northern & 44200 & 15 & 0.663 \\
Eastern & 173700 & 30 & 5.210 \\
Central \& Khartoum & 76000 & 126 & 9.089 \\
Kordofan & 214000 & 70 & 14.981 \\
Darfur & 259000 & 63 & 16.186 \\
Southern & 351200 & 100 & 33.122 \\
& & & 79.251 \\
\hline
\end{tabular}




\section{Range rehabilitation}

The overall effects of range deterioration and degradation have been published by the Sudan Desert Encroachment Control and Rehabilitation Programme (DECARP, 1976) and by the United Nations International Conference on Desertification.

\section{Recommended goals}

Several goals for range rehabilitation have been identified:

introduction of a management system that will adequately maintain a balance between the grazing resource and the livestock population and sustain optimal production without damaging the resource base;

coordinate provision and siting of water resources and use them as an indirect factor in controlling seasonal stock movements in relation to range condition and availability;

control of fire;

survey and inventory of range resources for the production of maps that can be used to plan future development and strategies;

rehabilitation and improvement of denuded rangelands by protection and reseeding.

\section{Strategy for achieving goals}

The restoration of the range to its former condition and productivity is recognized as a major undertaking. The strategy of the Range and Pasture Administration is based on an ecological approach and the involvement of the pastoralists and others who are the target population of the improvement programme.

The corrective measures chosen to implement this strategy correspond to the nature of the problem and the prevailing environmental conditions within each ecological zone. The involvement 
of local populations and practical demonstrations are fundamental to this approach which aims at restoring range productivity and improving the economic condition and welfare of the people.

The strategy puts the rangeland into three management zones, each with its own planned interventions.

\section{Zone 1- Semidesert}

promulgation of laws prohibiting traditional rainfed cropping north of $13^{\circ} \mathrm{N}$.

encouragement of range rehabilitation by protection of denuded range sites, by artificial reseeding and by soil treatment to increase moisture storage.

application of water-harvesting techniques, water spreading and micro-irrigation techniques for food crop production and nursery establishment.

propagation of seeds and seedlings for reseeding, making of shelter belts and sand dune fixation.

construction of fire lines to reduce damage from uncontrolled bush fires.

\section{Zone 2; Low Rainfall Savanna}

integration of fodder production in the crop rotations of agricultural schemes and the development of mixed livestock/crop systems.

protection against seasonal fires.

rehabilitation and improvement of range resources in the vicinity of water sources. avoidance of conflict between farmers and pastoralists in both planned and unplanned schemes.

rehabilitation of the southern stock route to increase offtake with a view to restoring the balance between carrying capacity and stocking rates.

\section{Zone 3; High Rainfall Savanna + Flood region}

tsetse control.

introduction of mixed ranching systems.

application of prescribed burning for better use of range resources.

\section{BIBLIOGRAPHY}

Abbo H.H. - Survey of the Butana, land use department files. 1958. (Unpublished Office Report).

Abdel Magsoud Z. - The Butana region. Ph. D. Thesis, University of Cairo, 1970. (in Arabic). (Unpublished).

Abu Sin M.E. - The regional geography of the Butana north of the railway. M.A. Thesis, University of Khartoum, 1970. (Unpublished).

Doxiadis Associates - Land and water use survey in Kordofan Province. The project areas' Nomadic tribes. 1965.

Doxiadis Associates - Land and water use survey in Kordofan Province, survey of the dry season nomadic concentrations with an emphasis on the Hamar tribe. 1965.

El Sammani M.O., ed. - Kordofan resource inventory and development prospective by rural council. University of Khartoum, Institute of Environmental studies; the Government of Kordofan region, 1985.

FAO - Sudan: proposals for grazing land development.

EMASAR Phase II volume VIII. Rome, FAO, 1974.

FAO - Land and water resources survey in the Jebel Marra area, the Sudan: final report. Rome, FAO, 1968. (FAO/SF:48/SUD-17).

Gibb, Sir Alexander et al. - Kassala Province survey report to Sudan Government, 1968. 
Hunting Technical Services - Land and water survey in Kordofan Province of the Republic of the Sudan. Report on the survey of geology, geomorphology and soils, vegetation and present land use. Athens, Doxiadis Associates, 1964. (DOX-SUD-A-26).

Hunting Technical Services - Land and water resources survey of the Jebel Marra area: reconnaissance vegetation survey. Rome, FAO, 1968. (LA/SF/SUD/17).

Hunting Technical Services - Land use planning survey in Southern Darfur. Annex 1: soil and vegetation resources. Boreham, Wood, Hunting Technical Services, 1974.

Hunting Technical Services - Savanna development project. Final report + annexes 1-5. 1976.

Hunting Technical Services - Agricultural development in the Jebel Marra area. Annex 1: land resources. Boreham Wood, Hunting Technical Services, 1977.

Hunting Technical Services - Southern Darfur land use planning survey. Khartoum, Sudan, Ministry of Agriculture, Food, and Natural Resources, 1977.

Leach T.A. - Date trees in Halfa province.

Sudan Notes Rec., 1919, 2 : 25-31.

Mackinnon F. - Kassala Province. In: TOTHILL J.D., ed. - Agriculture in the Sudan. 1st ed. London, Oxford University Press, 1948. P. 699-735.

Maydon H.C. - North Kordofan to South Dongola.

Geogrl. J., 1923, 61 : 34-41.

Maxwell -Darling R.C. - Notes on the food of camels on the Red Sea coast and in North-eastern Kordofan.

Sudan Notes Rec., 1938, $21: 189-195$.

Miche S. - Acacia albida and other multipurpose trees on the Fur farmlands in the Jebel Marra highlands. Western Darfur. Sudan.

Agroforestry Systems, 1986, $4: 89-119$.

\section{Ministry Of Agriculture - Food And Natural Resources, SUDAN.}

Southern Darfur land-use planning survey, development plan, Annex 5, Social organization. Hunting Technical Services Ltd and Sir M. MacDonald \& Partners, 1974.

Newbold D. - A desert Odyssey of a thousand miles.

Sudan Notes Rec., 1924, 7 : 43-92.

Newbold D. - A note on the 'gizzu' or jizzu.

Sudan Notes Rec., 1924b, $\underline{7}: 129-130$.

Skerman P.J. - Land and water use survey in Kordofan Province of the Republic of the Sudan. Report on pastures and livestock in the project area. Athens, Doxiadis Itd, 1966.

Wickens G.E. - A preliminary note on the status of the oil palm (Elaeis guineensis) in the Sudan. Sudan Notes Rec., 1975, 55 : 185-188.

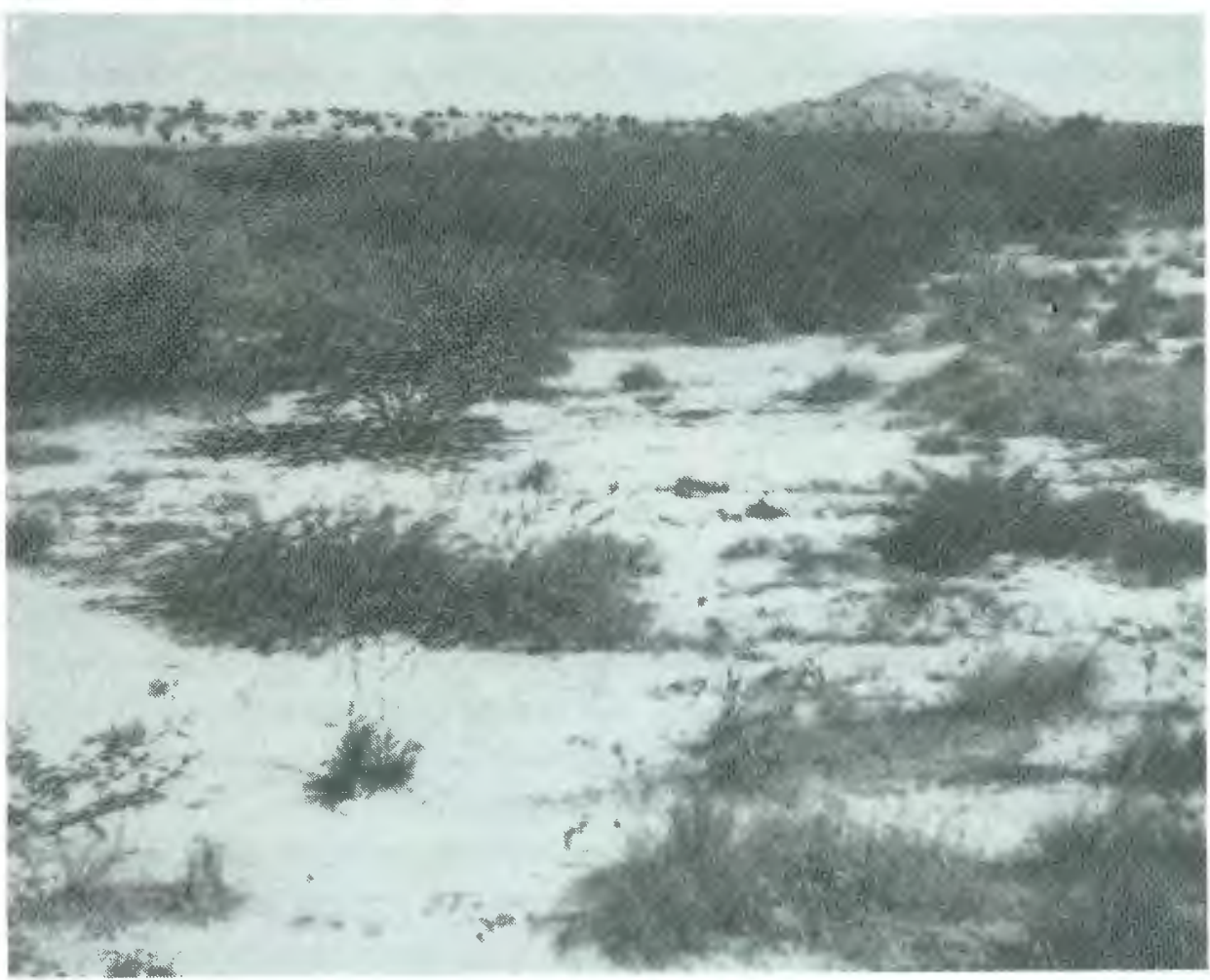




\section{RANGE USE}

\section{H. KHATAB EL MOULAH FALD}

Khatab K., El Moulah Fald, De Zborowski Isolde. 1993. Range use. In : Livestock production and sahelian rangelands potential: Republic of Sudan = Élevage et potentialités pastorales sahéliennes : République du Soudan. Darag A., Lamarque Georges. CIRAD-IEMVT - FRA. Wageningen : CTA-CIRAD-IEMVT, 20-22. ISBN 2-87614-088-8

For hundreds of years the nomadic herds of the Sudan made use of a minute proportion of the available feed resources. The majority of grasses were able to run to seed and provide a stock for regeneration in subsequent years. In the south of the area the ranker grasses produced large quantities of straw, of little nutritional value, little used by livestock, preventing access by small ruminants, and able to maintain a reservoir of parasites, especially ticks. The livestock owners combatted this problem by the simple expedient of setting fire to the vegetation, freeing enormous areas of useless bulk and encouraging early regrowth of perennial grasses, this being enabled by the mineral elements liberated by the fire. Firing generally took place in December or January, as the herds were leaving for the dry season pastures. Fires were not controlled, often caused considerable damage to the as yet unharvested crops and created conflict between livestock owners and crop farmers. The bare soil left by the fires was also susceptible to erosion, especially if the early rains arrived as violent storms.

To the north, fires were less frequent, mainly because the growth was (other than in exceptional years) inadequate to provide sufficient fuel for a good burn. Livestock, in effect, merely picked the choicest bits of the vegetation and, when the field layer was reduced to a poor quality feed of low nitrogen content they overcame the problem by browsing the protein-rich leaves of trees and shrubs.

During migration the major herds were preceded by scouts who sought out the best grazing and watering areas. Movements were more frequent where grazing or water was scarce. The provision of permanent water points can thus be seen as a major contributory factor, together with improvements in veterinary care, to the increase in livestock numbers and the consequent range degradation.

\section{Stocking rates}

The basis of an assessment of rangeland use is the number of animals that can be carried or are present per unit area in each ecological zone. A standard livestock unit (TLU or Tropical Livestock Unit) is generally assumed in order to calculate stocking rates, this being equivalent to an "average" cow of 1.0 TLU, a sheep or a goat being put at 0.1 and a camel at 1.2: this method has the merit of allowing stocking rates and carrying capacities to be expressed as a single figure but the unitary values ascribed to the different species are not very realistic.

Unfortunately, there is little real information on the distribution of livestock and the various "estimates" show enormous differences, depending on the source and the method used. Recent attempts to calculate animal populations do not cover large areas and are often very much at variance with the official data. Frequently quoted figures of $70 \%$ losses of cattle and $20-60 \%$ of small ruminants during the drought of the mid-1980s have not usually been taken into account in subsequent calculations of livestock numbers.

Two example will suffice to illustrate the nature of the problem. The first relates to a 1986 aerial census of the Gezira and the surrounding areas (Resource Inventory and Management 1987). A total of $50,570 \mathrm{~km} 2$ was included in the census, being virtually the whole of Gezira Province plus small areas of adjacent ones (Figure 1). Censuses were repeated at 2-month intervals and the numbers of animals counted were adjusted upwards by $25 \%$ for cattle and $120 \%$ for goats to take account of the numbers under various type of cover at the time of the census. The results, even then, provide density estimates (Table 1) well below the official figures for the Province. Cattle and small ruminant estimates on open range areas were less than half the official figures and camels only one-eight of them: on irrigated areas, where densities are in any case much higher but more animals are in the open, the aerial census estimates were still well below the official figures. 
Figure 1 - The zone covered by the aerial livestock survey in 1986

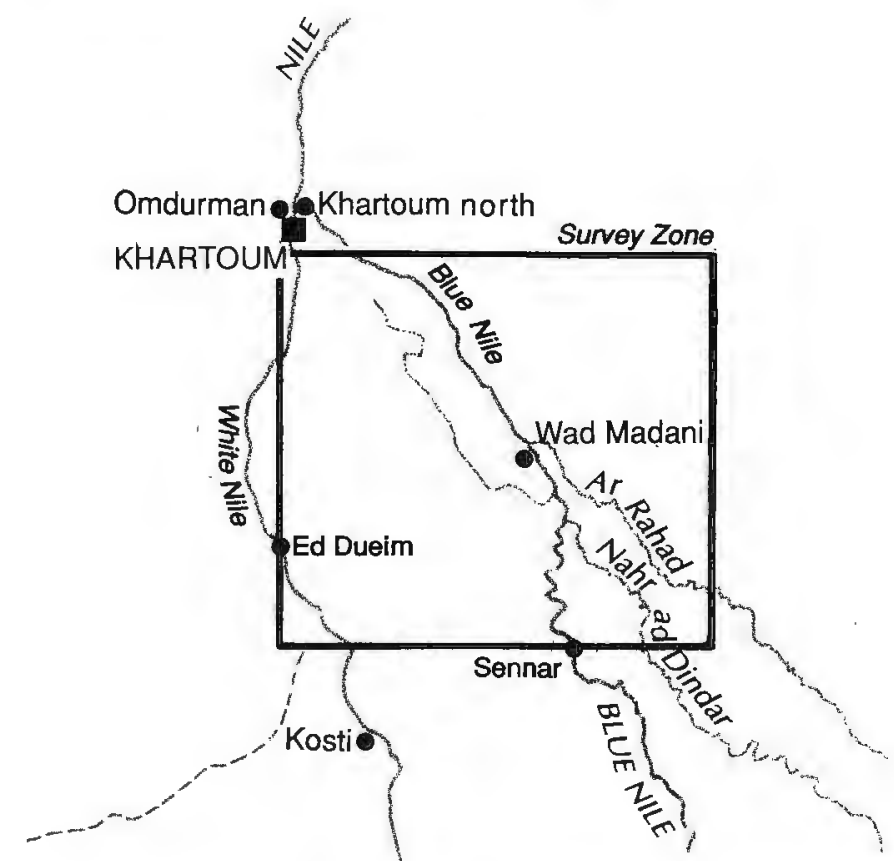

Table 1 - Livestock numbers and grazing pressure in Gezira Province

\begin{tabular}{|c|c|c|c|c|}
\hline Parameters & \multicolumn{4}{|c|}{ 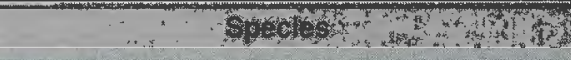 } \\
\hline & Cattle & Sheep & Goat & Camel \\
\hline Official figures ('000) & 647 & 1410 & 1411 & 167 \\
\hline Density $(\mathrm{N} / \mathrm{km} 2)$ & 25 & 55 & 55 & 8.5 \\
\hline Aerial survey $(38,000 \mathrm{~km} 2)$ & & & & \\
\hline February density ( $\mathrm{N} / \mathrm{km} 2)$ & 9.6 & 15.8 & 25.1 & 0.7 \\
\hline April density ( $N / \mathrm{km} 2)$ & 11.9 & & & 0.8 \\
\hline Irrigated areas $(12,500 \mathrm{~km} 2)$ & & & & \\
\hline Average density $\left(\mathrm{N}^{\circ} / \mathrm{km} 2\right)$ & 20.4 & & & 0.4 \\
\hline Stack observed from the air (\%) & 48 & & & 12 \\
\hline
\end{tabular}

A second example is provided by a survey carried out by OXFAM in Red Sea Province in March and September 1989. The figures for the period at the end of the rains in March, compared to those for September, are higher for sheep and goats (13-19\% being in sedentary holdings), similar for cattle (with more than half close to the main towns) but very much lower for camels. Compared to the official figures the OXFAM estimates are much less, $50 \%$ for cattle and camels and $80-90 \%$ for small ruminants (Table 2).

\section{Table 2 - Livestock numbers and grazing pressure in Red Sea Province Species}

\begin{tabular}{l|c|c|c|c|}
\hline \multicolumn{1}{c|}{ Parameters } & \multicolumn{4}{c|}{ Species } \\
\hline & Cattle & Sheep & Goat & Camel \\
\cline { 2 - 5 } Official figures ('000) & 47 & 260 & 549 & 110 \\
OXFAM count ("000) & $21-22$ & $143-212$ & $332-482$ & $40-58$ \\
Ratio OXFAM/official & 0.47 & 0.80 & 0.88 & 0.53 \\
\hline
\end{tabular}

oxfam 1990

Official figures are now derived from the base established in 1976 (Watson et al.: Resource Management and Research 1976) and have been increased annually on assumed reproduction and mortality rates, except during the two worst drought years. Others sources assume even greater and totally unrealistic animal densities.

The number of animals present in the area covered by this atlas is shown in(Table 3 ) Official figures are usually given for administrative regions or provinces, of which some are only partially or even marginally represented in the present study area. In this last case the numbers have been recalculated on the basis of the proportional area. The stocking rates are provided for 1976 (the base year) and for 1986 (the latest year for which official figures are available). The very large and 
RANGE USE (CONTINUED)

RANGELAND UTILIZATION AND DEGRADATION

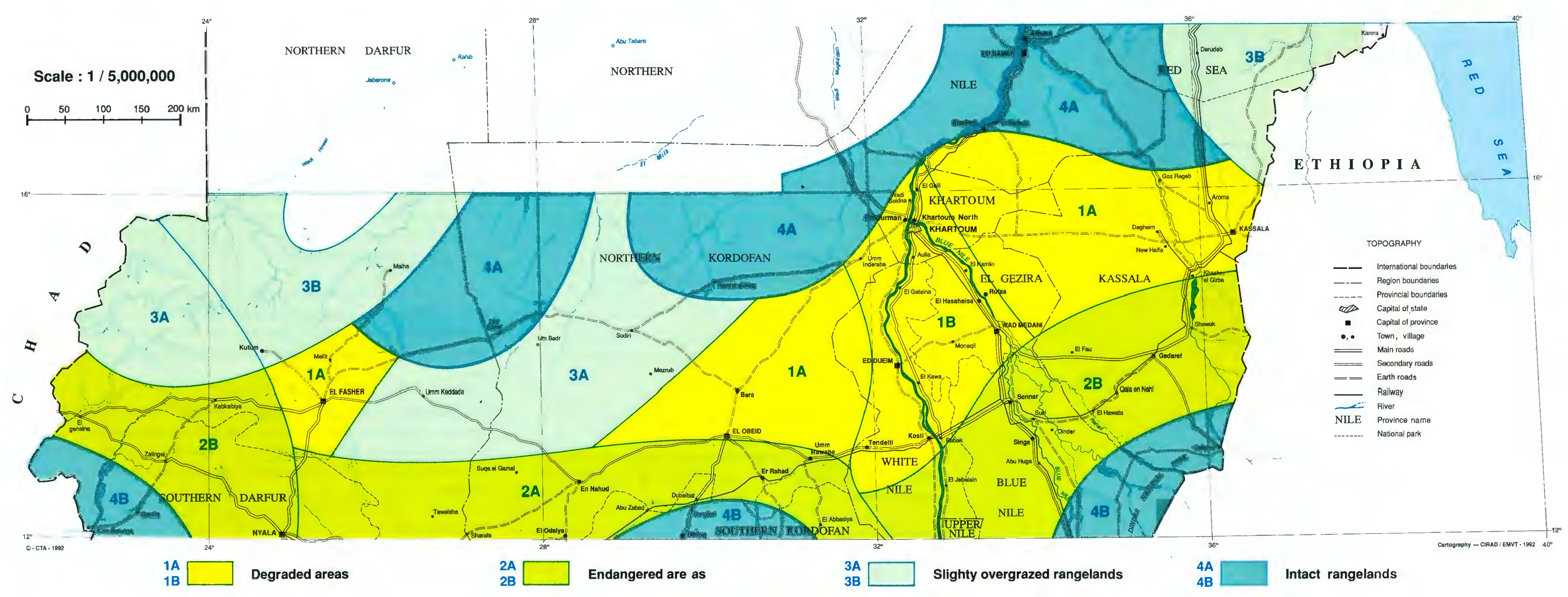


apparently unexplainable differences are obvious, as for example a general increase of $20-30 \%$ but an increase of $50 \%$ for the Gezira and $115 \%$ for Northern Darfur. Both these last areas are totally included in the mapped area and proportional calculation errors can thus be excluded. In spite of statements that regular quotients are applied across the board this is obviously not the case.

A second method of calculating the pressure on the feed resources is one that takes account of the amount available (see section on Primary Production). Domestic herbivores are assumed to eat dry matter equivalent to $2.5 \%$ of their live weight every day, or just over $6 \mathrm{~kg}$ per TLU. The whole of primary production is not, however, available to animals, in part because some of it is inedible and in part because some is inaccessible. In addition, total consumption of plant material would lead to the death of perennial plants and loss of the seed bank in annuals. Most reccommendations of best use are that actual consumption should be one-third to one-half of the feed on offer: this then allows, at the same time, the plants to survive and regenerate and the animals to select the best of what is available.

Table 3 - Livestock numbers and grazing pressures in the Sudan

\begin{tabular}{|c|c|c|c|c|c|c|c|c|}
\hline \multicolumn{4}{|c|}{ Official livestock number $1986(000)$} & \multirow[b]{2}{*}{$\begin{array}{l}\text { Mapped area } \\
\text { (0ookn') }\end{array}$} & \multicolumn{2}{|c|}{$\begin{array}{l}\text { Livestock in } \\
\text { mapped area }\end{array}$} & \multicolumn{2}{|c|}{$\begin{array}{c}\text { Density (TLUy } \\
\left.\mathrm{km}^{2}\right)\end{array}$} \\
\hline Province & Catte & $\begin{array}{l}\text { Sheop } \\
+ \text { goats }\end{array}$ & Cameis & & $\%$ & TLU (000) & RuM 1086. & RMR 1976 \\
\hline Red Sea & 3 & 40 & 5 & 20 & 5 & 13 & 0.65 & 1.03 \\
\hline Nile & 45 & 512 & 54 & 85 & 80 & 161 & 1.90 & 1.50 \\
\hline Kassala & 826 & 2,984 & 651 & 124 & 100 & 1906 & 15.37 & 12.90 \\
\hline Gezira/Khartoum & 720 & 3,696 & 183 & 44 & 100 & 1309 & 29.75 & 19.53 \\
\hline Northern Kordofan & 1204 & 4941 & 976 & 216 & 100 & 2869 & 13.28 & 10.07 \\
\hline Northern Darfur & 1165 & 3107 & 259 & 173 & 100 & 1786 & 10.32 & 4.79 \\
\hline Southern Darfur & 878 & 702 & 41 & 43 & 25 & 997 & 23.19 & 18.97 \\
\hline Southern Kordofan & 283 & 273 & - & 20 & 15 & 310 & 15.50 & 11.84 \\
\hline Blue Nile & 635 & 1091 & 24 & 44 & 55 & 773 & 17.57 & 14.35 \\
\hline White Nile & 2008 & 3370 & 89 & 39 & 100 & 2452 & 62.87 & 49.77 \\
\hline
\end{tabular}

Source: ??

On the basis of a feed availability of $16 \pm 2 \mathrm{~kg}$ per TLU per day it is possible to arrive at a hypothetical carrying capacity for the area studied, and compare this to current stocking rates (Table 4). The figures for carrying capacity for the Northern and Eastern regions are obviously notional as almost all the animals are concentrated on the Nile in the first area and are very unevenly distributed. in the second case, most being in Red Sea Province. They are more generally relevant for the other areas and show that stocking rates are not too high in Darfur, somewhat high in Kordofan and excessively high in the Central Region. In this last area, livestock do not subsist on the range alone and receive some form of supplementation. It might also be deduced (Table 4) that official figures for livestock are probably about $20 \%$ higher than is actually the case. 
Table 4 - Actual and potential range stocking rates (TLU/km2) in major regions of the Sudan

\begin{tabular}{l|c|c|c}
\hline & \multicolumn{2}{|c|}{ Stooking rate } \\
\hline Negion & Official figures & Aerial census & $\begin{array}{c}\text { Calculated carrying } \\
\text { capacity }\end{array}$ \\
\hline Northem & 1.89 & 1.50 & $1.1-1.3$ \\
Eastem & 13.33 & $7.42 ?$ & $9.0-11.5$ \\
Central and Khartoum & 35.70 & 27.02 & $11.6-14.8$ \\
Kordofan & 13.47 & 10.22 & $8.7-11.0$ \\
Darfur & 12.88 & 7.60 & $9.5-12.1$ \\
\hline
\end{tabular}

Source: ??

\section{The feed situation}

The use of feed resources is related both to the types of animals which feed on them and to their movements. Livestock distribution patterns show that cameis and small ruminants are the dominant species in the north, while cattle are concentrated in the south. The division is not, however, totally rigid and many areas are used alternately by cattle and camels, each of which is able to occupy a particular niche at different times of the year. In addition, some areas in a particular zone may be reserved for one species, for example cattle in those areas with a good field layer, or those close to water, while the more difficult areas are grazed by the other species.

The mobility of the herds, that is to say the transhumant and nomadic practices, helps greatly in overcoming the loss in feed value of the natural resource during the dry season. This fluidity does, however, have disadvantages in the modern world: for example, in the availability of medical and veterinary services, the provision of children's education, and the "rational organization" of grazing regimes and water supplies. The advantages, from the owners'point of view, are that they and their animals escape from the plague of insects and the mud that are the normal consequences of rain in the southern areas and are able to use the northern pastures which would otherwise be wasted, and save the southern ones for dry season use. Mobility also allows, to a considerable extent, animals to find a diet of at least fair nutritional value throughout much of the year. This freedom of choice is, however, being more and more restricted by legislation on rights and times of access to resources which have always been subject to traditional if more flexible arrangements.

From the foregoing it is evident that each major ecoclimatic zone needs to be examined individually in relation to feed supply and animal nutritional status.

\section{The desert zone}

In the desert, feed resources are both widely scattered and not always available when most required. The "gizu", for example, is expected to occur in one out of five years but there was apparently none at all between 1965 and 1974 and in 1975 it was limited to very restricted areas. In the 15 years following, there were four "gizu" years but the areas where it occurred were such that only camels and small ruminants were able to take advantage of it. While the "gizu" is an essential feed resource, its impact at national level does remain somewhat limited. 
Administrators as well as livestock owners appreciate the "gizu", however, as tribal quarrels are fewer in "gizu" years. The Kababish are the people who traditionally make most use of the "gizu" and are prepared to travel as much as $1,000 \mathrm{~km}$ in search of it. Because camels, in particular, do not require free water when on "gizu" grazing these long distances are not as taxing as might first appear. Absences from the home base and its water supply of as long as eight months are possible in exceptional years. The herdsmen get their liquid requirements from camel milk but they also pay a penalty, in terms of their own health, in order that their stock can benefit: the cold nights of the desert winter result in bronchitis, pneumonia and rheumatism.

The fossil valleys of the Nile are a more reliable source of feed in the desert. In particular they provide a sure base from which forays in to the desert to take advantage of ephemeral feed supplies can be made, or act as staging areas on the routes to the few desert oases. In some years, individual storms of $60 \mathrm{~mm}$ of rain or more can lead to a sprouting of vegetation at the bases of hills or in small run-on areas. Camel herds then sally 100-200 km in search of these from their bases along the Nile, or in the Wadi el-Milk and the Wadi Howar, to which they return when the feed is exhausted. These relatively favourable wadi areas are occupied every year in the hope of such temporary supplies of feed but, in their absence, are themselves becoming more and more degraded.

\section{The hyper-arid zone}

The hyper-arid zone can only be used in the rains. The area is almost exclusively used by camels and small ruminants, which need watering less frequently than do cattle. Some "hafir" and boreholes have been provided to extend the area that can be used. The potential carrying capacity has been estimated at $26 \mathrm{TLU} / \mathrm{km} 2$ (Harrison and Jackson 1958) on those areas which are on Basement Complex soils but it has to be assumed that this figure is valid only for the 4-8 month period when it is possible for the area to be used. A primary production of $600 \mathrm{~kg} / \mathrm{ha}$ is implied by such a carrying capacity, a biomass which can only be achieved in areas receiving more than 200 $\mathrm{mm}$ of rain. Such relatively high carrying capacities can apparently only be maintained by camels which make efficient use of the browse layer.

The annual grasses in this zone have a short growing period that is mainly confined to August but at this time they provide a feed of excellent nutritional value. Maximum biomass is attained at the end of September or in early October. Temporary pools are formed during the short rainy period and some of the deeper ones contain water as late as November and December. The dried-out grasses continue to provide feed and are grazed until drinking water is no longer available. Much of the brittle straw, however, simply breaks off, falls to the ground and is eaten by ants or decomposed by bacteria and fungi, the remainder rotting away at the advent of the next rains. Much of the seed stock is dispersed over a wide area, leading to a certain homogeneity of vegetation types in the zone. The primary production from this seed bank in a particular year is greatly dependent on the amount and distribution of rainfall. 
The eastern slopes of the Red Sea Hills are a better grazing area than most of the remainder of the hyper-arid zone because the steep valleys into which rainfall is channelled provide a good feed resource. The pattern of use is generally similar to that of the rest of the zone and there is considerable use of browse. Some use by cattle is possible, however, particularly in the Ethiopian frontier areas which are accessible from bases that are only a short distance away.

In contrast, the very dry areas closer to the Nile and Atbara Rivers are less useful as pasture areas as the outlying clay areas do not constitute a feed reserve for animals which may venture far to the north. The feed potential of valleys themselves is greatly reduced as the dense system of cultivation impedes free access.

\section{The arid zone on sands}

The Sahel zone is an important grazing area for both cattle and camels. The former use it during the wet season and feed mainly on the field layer. This use is complemented by camels which are present mainly during the dry season and make more use of the browse layer. The installation of many permanent water sources in this zone has encouraged a semi-sedentary production. There can be little doubt, however, that some of these water points have been installed other than for sound economic and ecological reasons. This has allowed permanent use of large areas, which rationally should be used only seasonally, with vast bare and degraded areas being the result.

A single large capacity water source allows an area within a radius of $20-30 \mathrm{~km}$ to be permanently grazed. By the end of the dry season there is absolutely no vegetative cover left and the bare soils are susceptible to both water and wind erosion. Annual grasses are not allowed to set seed and there is thus no seed bank for subsequent years. The small stocks that remain are often lost if the seeds germinate in response to an early rain which is followed again by a long dry spell. The sparse and poor quality vegetation that does establish itself forms discontinuous patches and even these are becoming more rare with the passage of time. The once-valuable browse layer is also under attack to provide fuel wood for the expanding sedentary populations, further aggravating the effects of wind and providing little hindrance to wind-blown sand. Attempts to establish "green belts" around the major villages and towns have rarely been successful and in addition are extremely costly.

The arid zone is one in which there once existed a complex equilibrium between plants and animals. Too light a use could result in there being sufficient dry material to maintain a fire, destroying the dry season potential. Too heavy use, paradoxically, might have the same effect. A series of bad years could lead to an apparently spectacular decline in the feed value of an area but a run of good years served to restore the balance. Heavy settlement and increased numbers of animals have destroyed this natural system of checks and balances.

The sandy areas of the arid zone are also an important producer of gum arabic from Acacia senegal. Most gum is produced if trees are allowed to mature to 6-8 years before any harvest is taken, are tapped only during the dry season, and the old wood then pruned to encourage new 
growth. Increased population pressure, ignorance of the tree's ecological requirements, the loss of traditional ownership rights to trees, the high price of gum on the world market and the lack of other sources of cash have had serious negative effects on the long term productivity of this resource. Regeneration is reduced (and attempts to encourage it have not been very successful) and the areas laid bare are now largely covered by Calotropis procera, always a sign of degradation and a plant of practically no feed value.

Present trends in national policies and the world market for gum arabic may yet provide a reprieve for Acacia senegal. Heavy taxes are charged on export and the numerous artificial substitutes now available have led to lower returns. In addition there is not an unlimited market for the product and this seems to be at saturation point. The "gum arabic industry" is essentially one of opportunistic gathering, it is badly organized, returns are at best not very good and additional costs of transport and taxes are a disincentive to its production. This is all to the good of the range and to livestock production.

The carrying capacity of this Sahel zone has been variously estimated at $78 \mathrm{TLU} / \mathrm{km} 2$ (Harrison and Jackson 1958) and $50 \mathrm{TLU} / \mathrm{km} 2$ (Hunting Technical Services 1974). It would appear that even the lower of these figures, if the area were to be grazed for six months (equivalent to a primary production of $1,500 \mathrm{~kg} / \mathrm{ha}$ ), is too high for the zone as a whole but would apply only to the most productive areas. The zone is in fact grazed throughout the year and even the current stocking rate of $11-12 \mathrm{TLU} / \mathrm{km} 2$ is leading,to more and more degradation.

\section{Dry zone on clay}

The Butana has for long been considered to be a vast grass plain but the marked contrast that existed between this and the more wooded areas to the west is now less obvious. As a consequence of the loss of woody cover on the sands the principal difference between these and the clays is the distribution of the shrub layer. In Kordofan the shrub layer is somewhat more evenly spread over the whole area while in the Butana it is more or less confined to the drainage lines and some run on areas. Erosion in the clay plains often commences insidiously by the appearance of bare arcs in the field layer: water collects along these arcs which benefits the plants on the down slope, while at the same time the water-borne soil particles are deposited above. Plants that receive less water begin to disappear, and the arcs creep up the barely perceptible slopes to occupy the empty space.

It is evident here, also, that over use destroys the delicate balance that exists in these fragile ecosystems. The progressive loss of these vegetation bands results in poor water infiltration with consequent greater and faster run off. On the resulting denuded areas the seed reserve is carried away by the first rains and has no chance to germinate. Cattle and sheep, the principal grazing animals, are mainly responsible for this type of degradation. This was recognized many years ago when it was proposed (Harrison and Jackson 1958) that the clay plains be reserved for use by camels, especially in view of the fact that, needing watering only at intervals of 4-6 days they are much more efficient users of the whole area. 
In fact, Harrison and Jackson (1958) suggested a carrying capacity of $31 \mathrm{TLU} / \mathrm{km} 2$ for the clay plains or only about $40 \%$ of that they suggested for sand in the same climatic belt, thus attempting in some measure to acknowledge the extreme fragility of the clay plain environment. This area was also at risk, at least until the 1969s, from the frequent dry season fires. A carrying capacity of 31 TLU $/ \mathrm{km} 2$ implies a primary production of $740 \mathrm{~kg}$ of dry matter eaten over a five-month period but this recommended rate is certainly exceeded at the current time over much of the area. The Butana is a desolate sight these days with a few scattered dead and moribund stumps remaining in a vast sea of bare earth.

\section{Semi-arid zone and sand}

This is an area that is permanently occupied by livestock and at the same time the one which has suffered more than any other from the spread of cultivation. Between 1960 and 1987 it was estimated that more than a third of the national grazing resource had been lost, some from desertification in the north but most from advancing cropland in the south. The annual increase in cultivated area on semi-arid sand and clay combined is of the order of 200,000 ha. The pastoral response to this loss has been a systematic annual transhumance to the Bahr el Ghazal whereas in earlier time such a move was only made in very exceptional years.

The short time which animals can now spend in the northern areas means, of necessity, that the southern pastures are grazed much earlier than they used to be. Early grazing means that there is insufficient fuel in the later dry season to burn to encourage new growth. In addition, the traditional control of a group over times and numbers of stock grazing, has been lost and the situation is now often chaotic. Not only rights, but also the resource itself, are being eroded and it is clear that the composition of the vegetation now differs greatly from that described in the 1950 s and 1960 s. These negative effects are a further reason for attempting to re-established some rational form of control.

Conflicts between herders and crop farmers are more frequent and often more violent than heretofore. Part of the reason lies in the greater area under cultivation but the political problems in the south of the country can also be considered to be a contributory factor. Animals are driven more and more by their owners on to cropped areas, often by night. This means the problem is assuming a more fundamental aspect, it being not only over grazing and access but over ownership of the land itself. The traditional pastoral tribes consider they have historical rights to much of the area but the settled farmers consider the pastoralists as intruders, coming from afar but coming earlier and staying later than was the situation a few years ago.

Government response, faced with this conflict and with the lack of feed resources, has been to attempt to establish ranches or grazing blocks and to limit mobility to short distance transhumance to well-defined areas. Results do not seem to have been very good on such an area of 400,000 ha in Darfur and have been even less encouraging, some even say amounting to total failure, in Kordofan. In spite of this the same line is still being pursued by Government. 
Another factor is the tendency of pastoralists to settle. This is in particular the case for those who have lost a major part of their holdings and who no longer see the advantage of making long treks when they can be more comfortably settled near a permanent source of water. Other advantages arising from all or part of the household settling in one place include education for the children, medical services and the proximity of market facilities. The sedentary part of the family often cultivates a small plot, but usually with little enthusiasm as cultivation is viewed as being much harder work than herding, to complement the products of the herds and flocks.

\section{Semi-arid zone on clay}

If there are problems on the sandy areas of the semi-arid zone, it seems they are even more pronounced on clay. Access to water along the rivers is almost impossible in view of the intense cultivation, even though in theory livestock corridors have been delineated through these areas. In reality these corridors are far too narrow to allow of sufficient feed for animals on their way to and fro and throughout the year. The herdsmen accuse the cultivators, who indeed tacitly admit to it in order to try and limit damage to their crops, of moving the boundary markers, thus making an already inadequate provision even more restrictive. Farmers who themselves now own livestock believe they have further cause for complaint and accuse the nomadic livestock of bringing in disease and weed seeds. A few farmers believe this to such an extent that they remove dung from their fields to prevent weed growth even though they are aware of the benefits it has as a fertilizer. Conflicts are now sometimes so violent that the army has had to intervene.

Attemps to redress the situation and provide some rational solutions seem to have had even less success on the clay plains than on sands in Darfur and Kordofan. As an example, an area of 200,000 ha designated as a grazing reserve was quickly turned into a mechanized farming scheme when it proved impossible to manage livestock there. On the other hand, pastoralists have little respect for the prohibitions on grazing of domestic livestock in the Dinder National Park. They consider this area, just as they do the areas recently occupied for cultivation, as their traditional grazing fief and accuse the authorities of neocolonialism in attempting to deprive them of these ancient rights.

Even though the number of nomadic herds is being reduced there has been no reduction in livestock numbers and new production systems are evolving. Herd and flock output shows increases in line with improved management, in particular as animals are sold at younger ages. Sedentary farmers buy young sheep from the traditional owners, to fatten them on crop or agroindustrial by-products and then send them by lorry to Khartoum where they find a ready market. On the major agricultural schemes, most farmers now have more than just a donkey or two and a few animals used to provide power: a growing number now keep, on a more or less commercial basis, some 10-20 cattle and as many as 50 small ruminants. The animal are penned at night and daily herding is under the control of a hired herder, who is mainly paid in kind but who also has some of his own animals in the herd. The major feed resource is the crop residues and the weedy growth on canal banks.

In the Gezira there is more of this latter kind of feed available, particularly between July and October. From November to February, sorghum stubbles and residues and groundnut haulms provide the main feed. In March there are limited areas of wheat stubble to graze, with some cotton stalks from mid-April, but in general the feed situation is at its most critical in the period March-June. At this time it is usual to feed some stored straw and provide some supplementary concentrates but weight losses are still the price that has to be paid and in bad years the death toll mounts. A recent development is that of cooperative milk production, local cattle being crossed with Friesians, especially in proximity to the larger villages in the main irrigated areas.

A further development is investment, in the economic sense of the word, in large scale livestock production. The wealthier farmers build up herds of as many as several hundred head. The younger male members of the family assume responsibility for a seasonal transhumance to the north. In this way the home-based feed supply of the irrigated lands is available in the dry winter season where there is plenty of water, in what for traditional pastoralists is almost the most difficult time of the year. These new "pastoralists" are much better organized than traditional owners, partly because of these advantages but also because of their knowledge of and their advantageous position in relation to the major markets. 


\section{The Darfur mountainous area}

This is not a homogeneous area in terms of climate and resources. It is, however, a clearly differentiated and partly self-contained production system that makes full use of the resources of Jebel Marra and the various valleys to the west and south which are a prime dry season resource. Livestock owners here are relatively well off: those in the north of the area are estimated to have the equivalent of 35 TLU for an average household of seven people, and those to the south may have double this number. These holdings are $20-40 \%$ greater than the national average for the same latitude band. Agriculture has not expanded to the same extent here as farther to the east and traditional grazing areas have not suffered the same degree of encroachement, except along the new highway from Nyala to El Geneina.

The political frontier with Chad is just that. There is no physical or natural barrier to free passage and Darfur has always been influenced to some extent by the west, the Fellata herders with their Um Bororo cattle being a case in point. The dry season transhumance is not necessarily directly south to the Bahr el Arab and many herds have traditionally moved in a south-westerly direction into Chad and the Central African Republic. Insecurity in Chad in recent years has proved an impediment to this latter system and, indeed Darfur now finds itself an immigration zone for herds attempting to avoid the conflict there.

The reminder of Southern Darfur is also relatively better off than most of the northern pastoral areas, in terms of rainfall and soil and feed resources. As a result dry season movements, even here, are not so long in distance or in time as they are in many other areas.

Southern Darfur, whether it be Jebel Marra or the area in general, is far from totally exempt of the effects of climate. The drought of recent years has affected the area to a considerable extent with the worst affected areas being those on volcanic ash and on lithosols. Except close to the towns and large villages, however, the woody vegetation remains relatively intact. The browse layer along the major valleys (including the Wadi Howar) and on the higher points of Jebel Marra also remains in better conditions than elsewhere. It should also be possible here to restore the field layer within a reasonable period of time.

\section{Map summary}

An attempt has been made on the pastoral map to include data relating both to current stocking rates and to the conditions of the range itself. The result has been the identification of 15 zones which largely represent four major conditions, all presenting a somewhat sombre prognosis for the future. These can be described in decreasing order in relation to the problems they are facing.

\section{Very degraded areas}

This is the heart of the central area, from El Obeid to Kassala. The situation here remains critical, not only because the range resources are excessively degraded but also because the number of animals is still very high. Recovery of this area is not possible in the foreseeable future.

Two major areas can be identified:

Type $1 \mathrm{~A}$ pastures which comprise three discontinuous areas, one on clay and two on sand. One sandy areas is around EI Fasher and the other in east-central Kordofan. In all three areas the degradation is man-made rather than being a result of climatic change, and the situation is unlikely to improve while stocking rates remain high.

Type 1B comprises the plains close to the Nile, affected by the major irrigation schemes which, in fact, are also the principal feed resource. Stocking rates are thus far in excess of the capacity of the natural rangelands but present stocking levels will only be maintained if adequate crop residues and some sort of concentrate feed can be made available.

\section{Areas at risk}

These areas include almost the whole of the semi-arid zone. Their original production levels have been reduced mainly as a result of overgrazing, which in itself has resulted in part from animals coming here from the already denuded zones just described. It is again possible to identify two major areas: 
- area 2A is the semi-arid sandy zone which has had an influx of animals that in the past grazed farther to the north and which have added further impetus to a zone already at internal risk from drought. The major stock routes also cross this area and many livestock owners are turning to cultivation to provide an additional source of income and compensate (-) for (-) reduced (-) animal productivity. The relict natural vegetation requires urgent measures to conserve it if it is ever to be rendered productive again;

- the areas of 2B in Darfur and on the clay plains are still not so heavily stocked as to have caused excessive degradation. The current trend, however, is of more and more cultivation and a concentration of animals on areas of poor quality grazing.

\section{Lightly overstocked areas}

These hyper-arid and arid zones have mainly suffered as a direct result of climatic change. They are now, nonetheless, having to support livestock numbers well in excess of their carrying capacity. Again there are two areas:

\section{- North Darfur and western Kordofan designated 3A;}

- the arid zones of Northern Darfur just to the south of those in $\mathbf{3 A}$, as well as the Red Sea Hills in the east, both being noted as $3 \mathbf{B}$.

\section{Areas not seriously affected}

These are in general the areas where range production has yet to be reduced. The two major reasons and the zones that they represent are:

- most of the semi-desert area, classed as $\mathbf{4 A}$, which had to be abandoned at the height of the drought. It is now virtually inaccessible because of the denuded areas to the south of it and prospects for recovery are reasonably good;

- the mountainous areas (4B) have been less affected by climatic change than elsewhere and have been spared to some extent because they are relatively difficult of access. There is still risk of devastating fires in these areas. Some parts of this unit are partially protected (Dinder National Park) and others are of relatively little value as pastures (Nuba Mountains).

\section{BIBLIOGRAPHY}

\section{LIVESTOCK POPULATION}

Gezira Study Mission . Appendice on agronomy, mechanization and livestock. 1966. 260 p.

Gezera Livestock Integration Study. Devco Ireland. 1987.

Government of Kordofan Region - Inventory of animals at El Obeid Town and surrounding villages, to assess requirements of grown fodder, concentrates and water supply. Department of Planning and Economy and the Administration for Natural Resources. 1985. (in Arabic).

MAFNR (Ministry of Agriculture, Food, and Natural Resources) - Sudan national livestock census and resource inventory. The results of an aerial census of resources in the Blue Nile Province, Vol. 10. The results of an aerial census of resources in Sudan, Vol. 31. Khartoum, MAFNR, 1977.

MFEP (Ministry of Finance and Economic Planning) - Statistical abstract. Khartoum, Department of statistics. 1983.

Oxfam integrated livestock survey of Red Sea Province. ERGO, 1990.

Sudanese Meat and Livestock Marketing Corporation - National herd distribution. Khartoum, Sudanese Meat and Livestock Marketing Corporation, 1981.

Watson R.M., Tippet C.I., Rizk F., Jolly F. Beckett J., Scholes V, Casbon F. - Sudan national livestock census and resource inventory.

Khartoum, Veterinary Research Administration, 1977.

\section{RANGELAND UTILIZATION}

Abu Sin M.E., El Sammani M.O. - Socio-economic aspects of integrated resource management, with special reference to the forest resources of Kassala Province, Eastern region, the case of the Rawashda and Wad Kabu Forests. Government of the Democratic Republic of Sudan, Netherland Government, FAO, 1986. 
Babiker A.A., Musnad H.A., Shaddad M.Z., Wood resources and their use in the Nuba Mountains. In: DAVIES H.R.J., ed - Natural resources and rural development in arid lands: case studies from Sudan. Tokyo, United Nations University, 1985. P. 30-59.

Blake H. - Policy considerations in the production and marketing of gum arabic in Sudan. Khartoum, USAID. 1983.

Blunt H.S. - Gum arabic. Oxford University Press, 1926.

Boudet G., Delpiano P.G., Abdallah A. - Ecological management of arid and semi-arid rangelands in Africa, and the Near and Middle East. (EMASAR-Phase II). Vol. VIII Sudan. Proposals for grazing land development. Rome, FAO, 1978.

Briggs J. - The human and physical environments come together: a case study of the Gummulya scheme. In: DAVIES H.R.J., ed - Rural development in White Nile Province. Tokyo, United Nations University, 1986. P. 114-136.

Davies H.R.J., ed. - Rural development in White Nile Province, Sudan.

Tokyo, United Nations University, 1986.

EI Arifi S.A. - Development strategy for the arid zone of western Sudan. University of Khartoum, Department of Geography, 1978.

El Hassan, Ahmed Mohamed - The environmental consequences of open grazing system in the central Butana. M. Sc. Thesis, University of Khartoum. Institute of Environmental Studies, 1981.

FAO - Report on the workshop on livestock policy, range and feed utilization guidelines for droughprone African countries, Khartoum, Sudan, 1985.

GITEC - Gum arabic development. Unpublished final report for EEC, 1980.

Haaland G. - Social organisation and ecological pressure in southern Darfur. In: HAALAND G., ed. - Problems of savannah development: the Sudan case. University of Bergen, Department of social anthropology, 1980. P. 55-105. (Occasional paper)

Haarmann V. - Naturpotential und Grenzen der Landnützung im Südsahel des Südostlischen Jebel-Marra Vorlandes. Hamburg, Mensching, 1987.

Harrison M.N. - A report on a grazing survey of the Sudan. Khartoum, Ministry of Animal Resources, 1955.

Seil EI Din A., Obeid M. - Ecological studies of Sudan IV. The effect of simulated grazing on Acacia senegal (L) Willd seedling.

J. appl. Ecol., 1971, 8 (1) : 211-217.

\section{RANGELAND DEGRADATION}

Ball J. - Problems of the Libyan Desert.

Geogrl. J., 1927, 70 : 21-38, 105-128, 209-224.

Ballal A.I. - Suffering from neglect: development in Darfur.

Sudanow, 1987, $12(6-7): 23-26$.

Bari E.A. - Sudan. In: HEDBERG I.O. - Conservation of vegetation in Africa South of the Sahara. CAETFAT Symposium.

Acta Phytogeographica Suecica, 1968, 54 : 59-64.

Cloudsley -Thompson J.L. - Human activities and desert expansion.

Geogrl. J., 1978, 144: 416-423.

El Sammani M.O., ed. - Kordofan rehabilitation and development strategy. 3 Vols. Khartoum, Sudan government/UNDP, 1986.

Euroconsult - Reassessment rehabilitation programme, Kordofan and Darfur: final report to the Ministry of Finance and Economic Planning, Republic of Sudan. Arnhem, The Netherlands, Euroconsult, 1986.

Government of Eastern Region - Indicators of range problems of eastern region. Department of range and pasture, Seminar for combating desertification, 1983. (in Arabic).

Government of Kordofan Region - The experience of Kordofan region with desertification and drought. Department of planning and economy (MEF) and project operation unit (MANR), 1985.

Government of Kordofan Region - Desertification and drought in North West Kordofan (Sodiri). Department of planning and economy, 1985. (in Arabic). 


\section{RANGE USE (CONTINUED)}

Ibrahim F.N. - The problem of desertification in the Republic of Sudan with special reference to Northern Darfur Province.

Khartoum, Science Research Council, 1978. (Science Research Council Monograph N_8).

Jefferson J.H.K. - Soil conservation in the Sudan. Development and projects. Khartoum, Ministry of Agriculture. $168 \mathrm{p}$.

Lamprey H.F. - Report on the desert encroachment reconnaissance in Northern Sudan. Nairobi, United Nations Environmental Programme. 1975. 14 p.

Manger L.O. - The sand swallows of our land - over-exploitation of productive resources and the problems of household viability in the Kheiran - a Sudanese oasis. (Department of socia anthropology occasional paper $n$ 24). University of Bergen. Department of social anthropology. Bergen, Studia University Bookstore, 1981

Stebbing E.P. - The creeping desert in the Sudan and elsewhere in Africa. Khartoum, Sudan Government, 1953.

Swift J. - Rehabilitation and long-term development for pastoralists in Red Sea Province, Sudan. Khartoum, UNICEF, 1986

Trilsbach A. - Desertification and rural changes in central Sudan. Ph. D. Thesis. University of Wales, Swansea, 1983

Sudan, Ministry Of Food, Agriculture And Natural Resources - Rehabilitation of range resources and livestock production improvement: Democratic Republic of the Sudan.

United Nations Sudano-Sahelian Office, 1979. 8 p.

United Nations, Sudano -Sahelian Office, UNSO - Desertification control and range management: an approach to the protection and further development of the range resources in western Sudan.

Findings of the UNSO rangeland mission, 16 May-3 June 1981. UNSO/DES/INT/81/002.

United Nations Sudano-Sahelian Office, $1981.60 \mathrm{p}$

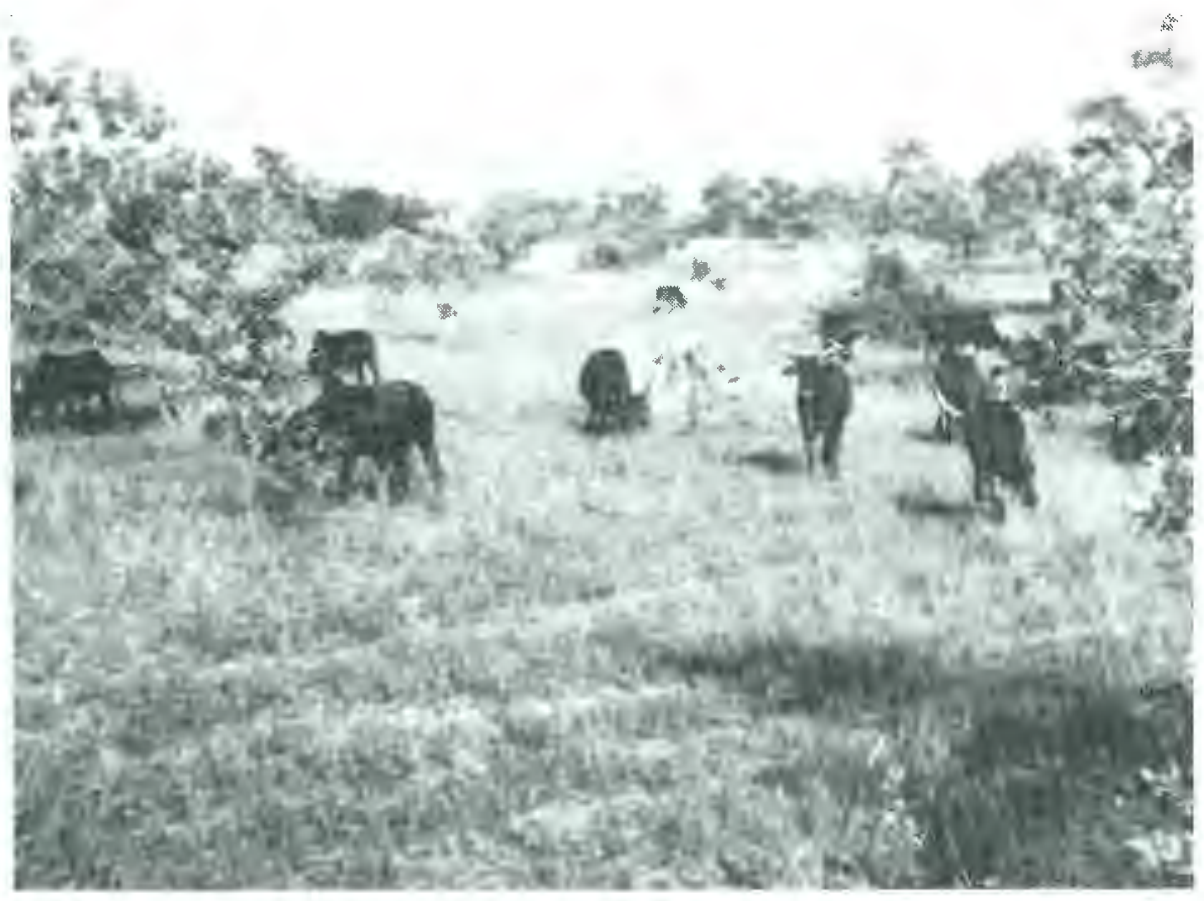




\section{G.FORGIARINI}

Areas under cultivation in the arid and semi-arid zones of the Sudan are considerably greater than they are in the other countries of the Sahel. A full treatment of cultivation and cropping patterns is therefore justified for several reasons:

I. the agricultural systems are diverse and include enormous areas under irrigation and mechanized farming as well as traditional rainfed ones;

II. cropping is accompanied by small scale sedentary animal production which competes for resources with extensive nomadic pastoralism, in particular on the better grazing areas;

III. the rapid development of large mechanized schemes often leads to loss of traditional migration routes, causing problems between pastoralists and farm authorities, with the former complaining that the livestock corridors provided are too few and too small and the latter that animals cause damage to crops;

IV. the development of large scale agriculture seems to be outstripping even the normal statistical services and their estimations of the areas under cultivation (variable as they are, depending on the source) are seldom in agreement with what can be ascertained from satellite imagery.

With respect to this last point it is interesting to compare the "official" view of large scale irrigated and mechanized schemes (Figure 1) with the latest imagery. Satellite mapping of areas under mechanized cultivation shows these to be three or four times more extensive than the official figures, while irrigated schemes show an explosion in their numbers.

\section{Fig 1 - Central Sudan : principal agricultural schemes}

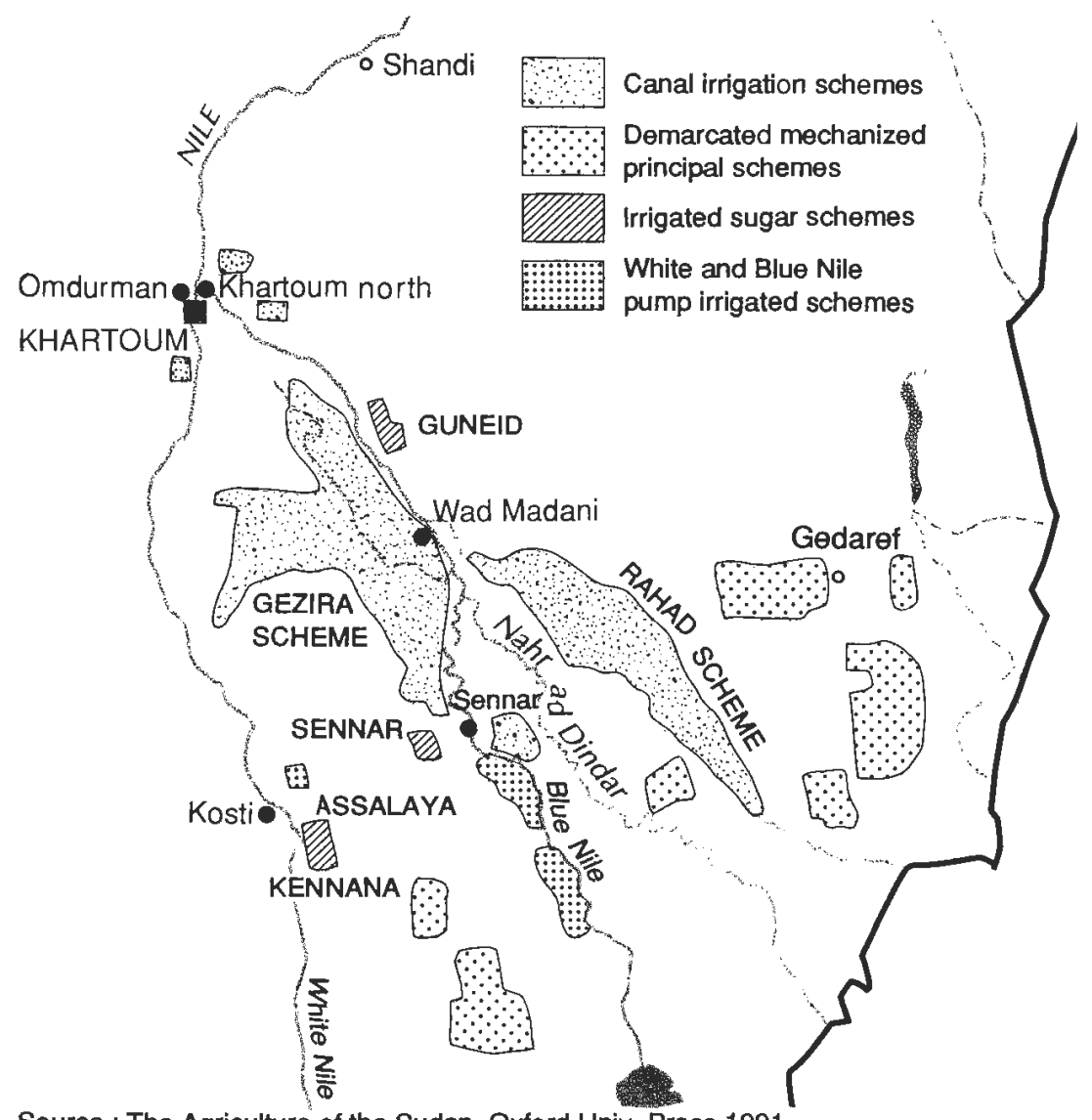

Source : The Agriculture of the Sudan, Oxford Univ. Press 1991

The mapping done from satellite data, covering $805,000 \mathrm{~km}^{2}$ north of the $12^{\circ} \mathrm{N}$ parallel of latitude, has allowed a reasonably accurate and up-to-date estimate of agricultural areas to be compiled. It shows that irrigated agriculture covers $16,380 \mathrm{~km}^{2}$ (equivalent to $2.0 \%$ of the total area), mechanized schemes extend to $\mathbf{2 3 , 2 8 0} \mathbf{k m}^{2}(2.9 \%)$, there are $70,350 \mathbf{k m}^{2}(8.7 \%)$ of land under rainfed agriculture, and cultivation in wadi beds covers a further $8,050 \mathrm{~km}^{2}(1.0 \%)$. 
It should be noted, however, that agriculture is concentrated east of the White Nile up to $15^{\circ} \mathrm{N}$ where some two-thirds of available land is under cropping. To the west of the Nile cropped areas represent $20 \%$ of all land in the zone with an annual rainfall in excess of $300 \mathrm{~mm}$.

\section{Mapping criteria}

The figures quoted for the satellite image analysis are subject to some reservations even though identification of cultivated areas is done according to certain criteria which are more or less reliable.

\section{Irrigated areas}

The main criterion is the marked contrast between the actively growing vegetation of the irrigated areas during the dry season and the dead areas that surround it. Absolute identification of these areas is limited only by the size of the pixelles, which correspond to an area some 250 metres square, equivalent to about 6 ha. Areas smaller than this cannot be identified with certainty and the figure for irrigated areas does not therefore include the numerous small gardens irrigated by mechanical pumps which are common along the Nile.

\section{Mechanized farming}

These areas are clearly recognizable as characteristic rectangular blocks. It is not possible on the images, however, to determine what proportion actually carries a crop and what is fallow. The area given for this activity is thus certainly greater than that which is actually being cultivated. The area figure nonetheless represents that which is effectively denied to livestock, especially as current fallows are very recent and have littie vegetation.

\section{Traditional rainfed agriculture}

Similar reserves about the actual cropped area and the area of fallow apply as for mechanized farming. Many individual cropped areas are below the limit for correct identification but the whole presents a characteristic pattern on the imagery. Identification of this type of activity is also aided by the numerous villages and by a considerable reduction in the woody vegetation. Degraded areas around villages are included in the area calculated for this activity but this is compensated for on the map by the many isolated small areas of cultivation which are not shown because of the scale used. Mountain areas (and especially Jebel Marra) are not mapped as cultivated because such areas do not show sufficient contrast with the surrounding savanna woodland for them to be clearly identifiable. Small cultivated areas along narrow river valleys, which are often under or very close to dense tree cover, are similarly not mapped.

Traditional rainfed agriculture is thus certainly under-estimated in the areas of higher rainfall with a concomitant overestimation of areas available for grazing. The date also represent the state of affairs at the time the satellite images were taken. The areas actually marked on the map are valid at a later time only insofar as the shifting cultivation that is practised does not take the cultivation outside the zone covered by the analysis. The usefulness of this type of synthesis, however, is to show the pattern of cultivation, which is due at least as much to social and economic factors as to those which normally strictly govern arable cultivation such as climate and soils.

\section{Irrigated agriculture}

Large irrigated areas are restricted by the regional topography and are found at the level of the major rivers. They can then be irrigated by gravity from the large dams constructed to raise the river level and store its water. Generally speaking, cotton comprises one-third of the area, one-third is in food crops (groundnuts, sorghum in the hot season and wheat in the winter, sesame and vegetables) and one-third is fallow. The exception to the general rule is the large scale monoculture of cane sugar.

\section{Gezira}

The Gezira is the oldest and by far the largest of Sudan's irrigation schemes. It takes its water from the Sennar dam on the Blue Nile. It covers much of the area between the two Niles from Jebel Aulia in the north to Blue Nile Province in the south where it interdigitates with the two southern branches of the El Managil Extension. The whole of the area is cultivated with the exception of the village areas and a few sandy eminences rising above the general level of the surrounding plain. 


\section{Rahad}

The Rahad scheme is situated to the east of the river of the same name, the river itself being a major tributary of the Nile. The scheme became operational in 1977. A characteristic of this scheme is the standard form of the plots, which are rectangular and in the ratio $7: 1$. Water for irrigation is drawn from the Rahad, although there are no large dams on it. The villages of the scheme, the principal one being Fau, are situated at regular intervals throughout.

\section{New Halfa}

The New Halfa scheme is second in size only to the Gezira. It is found to the west of the Atbara river. The Khasm el Girba dam provides a regular supply of water for irrigation. The general plan of the scheme is identical to that of the Rahad. New Halfa town is in the centre of the scheme.

The least productive areas of this scheme were converted to cane production during 1986: by the end of that year almost $60 \%$ of the area was down to cane. The remainder of the area was not cultivated but there were no indications of degradation on the satellite images.

\section{Kenana}

This is the largest of the specialist cane schemes and started to become operational in 1981 on an area of 41,000 ha. According to the World Bank this is one of the biggest sugar schemes in the world. The main sectors are $1.5 \mathrm{~km} \times 2.0 \mathrm{~km}$ in extent and divided into narrow beds that are unmistakable on the satellite images.

Kenana is located, close to the White Nile, to the east of Kosti and to the south of the railway line from Kosti to Sennar. An additional area of 10,800 ha is found to the north of the railway and there are several smalier areas close to the Nile.

\section{Guneid}

The Guneid scheme comprises two irrigated areas close to the village of the same name to the village of Rufa'a, east of the Blue Nile. The northern area is less developed and only about $50 \%$ of it is cultivated.

\section{Sennar schemes}

There is a large number of small irrigated areas on either side of the Blue Nile in the vicinity of Sennar town, particularly in the rhomboid whose top section is formed by the Nile and the Dinder rivers at their confluence. They extend as far south as EI Suki and the line of rail from Sennar to EI Gedaref.

One of the areas, $5 \mathrm{~km} \times 50 \mathrm{~km}$ in extent and cultivated to sugar cane, is effectively an extension of the Gezira. The other blocks are smaller and somewhat scattered. They are situated in an area of fragile ecology. There are numerous indications of degradation, especially on thalweg slopes and at the bases of the interfluvial areas, including within the irrigated areas themselves.

\section{The Gash delta}

The gash delta, to the north of Kassala, is watered seasonally by the normal run of the river between July and September. There are no major engineering works to control the flow. The river is very flash and torrential at times. As a result the individual blocks are small (at the limit of perception on the satellite photos) and scattered, with groups of blocks being connected by canals. The cultivated areas are on the alluvial terraces from the north to the centre of the delta and are under water for only a short period. The main crops are cotton, sorghum and castor. The area shown cultivated on the map is certainly an underestimate of the actual area because of the small size and scattered nature of the blocks.

\section{Mechanized agriculture}

Mechanized agriculture occupies large blocks of land with an average size of 350 ha. This area is sub-divided into smaller plots. This type of operation is usually found on sandy-clay or clay soils which are not normally used for traditional agriculture as they are difficult to cultivate without heavy machinery. The requirements in capital investment are consequently high. The entrepreneurs owning these schemes operate in a system that is totally divorced from the traditional small scale agriculture in which farm size is usually less than 1 ha.

Crops are grown for the market and are mainly sorghum and sesame. The diversity of soil types induces a corresponding diversity in field sizes. The mechanized schemes benefit from large financial loans that are not available to small farmers because these latter are still not organized 
sufficiently to be able to influence national agricultural policies. The technological and managerial skills required to operate large farms also differ from those required or usually available in the small scale sector. It is difficult to see how, in the foreseeable future, the dichotomy of large and small scale operations can be integrated.

Their was little development of mechanized agriculture to the west of the Nile up to 1986. In fact there were only two in the zone covered by the satellite imagery, between the flood plain of the Abu Habil river and the Nuba mountains. In contrast the area occupied between the Niles is almost as much as that under traditional rainfed cultivation and mechanized agriculture is continuing to take over all available land as far as the boundaries of the Kenana scheme. The areas actually under cultivation are apparently greater than those originally granted and marked out. This expansion does not seem to be in competition with other agricultural systems, nor is it limiting their future development.

Better rainfall and higher population densities have encouraged the development of mechanized farming to the east of the Blue Nile and as far as the Ethiopian border. Southern Kassala Province, for example, is almost entirely under cultivation as far as the foot of the mountains, with the different systems being tightly interwoven. Mechanized agriculture is, indeed, rapidly occupying land as far north as $14^{\circ} 30^{\prime} \mathrm{N}$ to the west of Gedaref.

The natural savanna woodland has almost entirely disappeared along a $150 \mathrm{~km}$ wide band in the south of Kassala Province. Land available for livestock is now very limited and that is mostly fallow of very poor quality. It will be necessary, within a very short time, to abandon the traditional migratory movements between the Butana and the wetter foothills of the border area, which will entail serious consequences for livestock production.

\section{Traditional agriculture}

Subsistence production is the major objective of the traditional systems. The main crops are cereals. Bulrush millet (Pennisetum typhoides) is the principal species on sandy and clayey-sand soils: short or long season varieties are used in response to local climatic conditions. Sorghum is grown on heavier soils and in the valleys or in areas of higher rainfall. Subsidiary crops include a wide range of vegetables, including Irish potatoes, tomatoes, squashes and other cucurbits, onions, kerkadeh (= Hibiscus sabdariffa), sweet potatoes and other root crops. Some oilseeds (principally groundnuts and sesame), and pulses are also grown, as well as small areas of tobacco.

\section{The zone north of the $300 \mathrm{~mm}$ isohyet}

In the north of the area covered by the satellite imagery almost all cultivation is in the river valleys: $90 \%$ of the population lives in these valleys and on their terraces, even though these zones are equivalent to only $5 \%$ of the area. Small vegetable gardens cover a third of the area suitable for this form of production and they are often watered by small pumps. It is thus possible to obtain crops in the winter season, including wheat and barley. Date palms are an important element of these systems. Agriculture is usually closely associated with animal production and most livestock owners have at least a part of their family resident in a river valley. Partly as a consequence of this, livestock movements are limited in time and in space. Off-farm income from wage labour or from commercial business adds to the total resources available to many of the families.

\section{The zone south of the $300 \mathrm{~mm}$ isohyet}

South of the $300 \mathrm{~mm}$ isohyet the agricultural systems vary from west to east.

- Darfur: there are major areas of cultivation close to the main population centre such as El Fasher or Umm Keddada. The sandy plain between the Wadi el Ku and Jebel Marra, where there is clear evidence of wind erosion, is also densely cultivated: sandy areas at higher altitudes are less degraded. In the El Geneina area the density of cultivation decreases from south to north. There is, however, a heavily cultivated area along the border with Chad north of the $14^{\text {th }}$ parallel of latitude where food crop production of millet and sorghum is reputed to be surplus to local requirements. The alluvial terraces of the major wadis (Kadja, Barsi, Azum, Debarei and Kulma) to the west and south of Jebel Marra are very densely cultivated and highly productive. The narrowness of the valleys and the scattered nature of the many small plots in the shallow depressions that receive run-on water have not allowed these areas to be mapped at the scale used. Similarly, the numerous small plots at altitudes in excess of $800 \mathrm{~m}$ have not been mapped. 


\section{CROPPING (CONTINUED)}

Land higher than 1000-1200 m, for example in the valleys to the south-west of the Deriba crater on Jebel Marra and on the southern slopes of Jebel Gorgueil, is pocked with many small plots. Terrace cultivation on Jebel Marra shows maximum concentration to the north-east of Deriba, around Suni, Tora Tonga and Terang at altitudes greater than $2,000 \mathrm{~m}$.

- Kordofan: a large number of small villages is regularly distributed over the gently undulating "qoz" which is an area of dense human settlement. The major area of cultivation is in the southwest of the Province, to as far north as En Nahud. The area under crops decreases towards the east. The major desert tracks strongly influence the amount of land cultivated and there are concentrations to the north of the En Nahud-El Obeid road, along the route to Kosti especially around Umm Rawaba, and to the north of Bara on the road to Khartoum.

Agriculture here extends somewhat to the north of the $300 \mathrm{~mm}$ isohyet, most probably because this is a zone in which the gum arabic (Acacia senegal) tree is a dominant feature of the vegetation. The current vegetation is indeed to a large extent anthropic insofar as the gum tree is encouraged to grow by the human population. Increased demographic pressure no longer allows the traditional cultivation-fallow cycle which to a large extent allowed the maintenance of long term fertility while the fallow duration was of at least $7-8$ years. The cycle is becoming shorter and shorter and in some areas, as indicated by cultivation and fallow having the same aspect on the satellite images, cultivation is now almost continuous.

As cultivation intensity increases the production of gum decreases. Rational exploitation of gum, with only moderate tapping, allows stable production over a tree life of 18-20 years (Vidal \& Hall, 1953). Tapping the trees when they are too young results in a much shorter life. Currently there is rapid transition from a stable sylvo-pastoral production system in which animals and trees are in equilibrium with light and short term cropping, to one in which agriculture dominates to the detriment of the other two components. This has serious consequences for the pastoral economy, which was well aware of the value of the gum belt and was always careful not to damage it.

- The east of the study zone: discontinuous small scale traditional rainfed agriculture covers large areas of the sandy-clay plateaux where the rainfall is adequate. Between the two Niles the expansion of the traditional agricultural system has been helped by the parallel development of large scale modern production and by population increase. Cultivation on the good quality basaltic soils of the Gedaref ridge, which extends as far north as the Khasm el Girba scheme, has nonetheless been practised for many centuries.

The valleys and the alluvial terraces which border them are very heavily utilized. Even the permanently water-logged soils of the Dinder and Rahad river basins are used by small scale traditional farmers for crops with high water demand. Pressure on the land is so strong that the Rahad Nature Reserve has already been invaded and it will not be long before the Dinder National Park suffers the same fate.

\section{Supplementary livestock feeds}

The expansion of agriculture and the decline in the natural resources of the rangelands have induced pastoralists to seek and use supplementary feeds. Three principal types can be recognized.

\section{Hay}

Standing hay has been a traditional feed, particularly in the west, for a long time. Up to the 1960 s it was collected or purchased in small amounts and used for the animals left at the camp or homestead. Large stacks of hay are now, however, a familiar site in camp and village. The trade in hay has expanded rapidly since 1980 at the major as well as the intermediate centres of population in Darfur and Kordofan. A fourfold increase in the price between 1983 and 1989 helped many poor pastoralists, their herds devastated by the drought, to gain a kind of living but has done little to help range production as a whole.

\section{Cultivated forages}

Crop stubbles have always been used as livestock feed and have for long been collected and stocked by farmers and agropastoralists for their own use. More recently nomadic herdsmen have made full use of the feed opportunities provided by the irrigated cotton and mechanized sorghum schemes. 
Crops cultivated purely as livestock feed, particularly in the east of the country, now include Sudan grass (particularly the short season variety "abu sabeen") and "berseem" or Egyptian clover. In recent times Sudan grass and sorghum stalks have also been used by the nomads of Northern Kordofan and the Red Sea hills, even though the feeds may have had to be transported over long distances to be used for store stock or to be used for animals making the long treks to the main markets from the pastoral areas. The expenses incurred in providing this kind of feed is now an accepted item in the nomadic budget.

The use by government of some irrigated schemes to provide feed for animals is encouraging. The 70,000 feddans (of 140,000 cultivated) of sorghum grown in the New Halfa scheme in 1985 was in support of this policy. On a smaller scale the production of green feed in peri-urban areas is a major growth industry, not only in the major centres in the east and along the Niles but in the medium-sized and larger population centres in the traditional pastoral areas in Darfur and Kordofan.

\section{Crop residues and industrial by-products}

There has always been a degree of complimentarity between pastoralism and agriculture. This has been exemplified by the free access of nomadic animals to harvested fields to graze stubbles and residues in nominal exchange for the value of the manure. In recent years however the increased value of feed has resulted in farmers, and particularly large farmers, selling the rights to stubble grazing. As another and wholly undesirable development the large scale farmers are burning stubbles to prevent incursions by pastoralists under the guise that animal droppings introduce weed seeds and reduce the future potential crop production.

The traditional influence of the pastoral community has occasionally, even recently, been able to secure some concessions in order that they be compensated for both loss of traditional grazing areas and of crop residues. As an example there is the case of the Rufa'a el Hoi who have secured a promise to have allocated to them 50 newly demarcated mechanized schemes as a step in the directions of reacquiring tribal rights and in the integration of agriculture and animals.

Large scale agricultural production and manufacture provides a major feed source. In Sudan, oil seed cakes are the most important commodity, with cotton seed cake now being the most common. Cotton seed cake has become commonplace in small rural shops and is also sold in large quantities in the bigger regional centres. Although fed mixed with ground sorghum the demand now exceeds supply to such an extent that prices increased fivefold from 1983 to 1989.

\section{Settlement of pastoralists}

The growing involvement of pastoral groups in agriculture, whether this be in subsistence, cash or fodder crops, is leading to a reduction in herd mobility and even to voluntary settlement in more or less permanent villages. There have, however, being previous attempts at settlement of pastoralists extending back over 40 years and usually involving some form of coercion. Some have been relatively successful and others not.

\section{Hadendowa 1948}

Following continued failure of the rains over several years some 500 Hadendowa families were moved to Gedaref in 1948. Each family was allotted an area of 50 feddans which was prepared and ploughed by the government and sowed to sorghum under the supervision of a governmentappointed agricultural inspector. At the end of the first year $80 \%$ of the families deserted the scheme, ostensibly because many of their number had died due to malaria.

\section{The Hamshkoreib experiment 1951}

Sheikh Ali Betai attracted some Hadendowa to Hamshkoreib village for Koranic studies in 1951. There has been some spontaneous settlement in six other centres which benefit from education, health and veterinary services. Except for settlement the Hadendowa have continued to practise their traditional way of life by raising livestock and producing some sorghum. 


\section{Beja tribes 1958}

Several small schemes of about 1,000 feddans each were established and allocated to the Hadendowa, Artiga, Amrar, Ashraf and other Beja groups. The settlers were provided with tractors which were to be repaid in installments from income. After five years, however, due in the main to fluctuations in production most of the schemes were abandoned. Only three are known to be operational at present.

\section{New Halfa 1962}

The flooding of Lake Nubia behind the Aswan High Dam resulted in the displacement of many thousands of people, many of whom were ethnic Nubians whose ancestors had lived in the area for millennia. Members of pastoral tribes that were displaced included Shukriya, Beja and Rashaida. The New Halfa scheme has a favourable location for pastoralists close to the Butana and the Atbara river, to sorghum mechanized schemes, and to the Gash and Baraka schemes. The advantages of being able to maintain a pastoral way of life coupled to irrigated agricultural production have resulted in some success for this project.

\section{Gireih es Sarha 1969}

A pastoral association was planned with the objective of establishing a consumer cooperative and a flour mill by means of shares purchased by the Kababish. The project, with 50 families participating, operates in the Kawahla area to the west of Umm Badr. Other planned inputs included a water supply, development of a small irrigated farm and a contribution to cover the costs of some personnel. The government inputs included planning assistance, fencing and management staff during the early years. Although the original management plan was never adhered to and the Kawahla 'nazir' (chief) came to dominate the scheme it was considered successful in conserving the rangeland for the use of a limited number of herds.

\section{The Suki experiment 1972}

Following the failure of the rains in 1972 some 350 Hadendowa, Beni Amer, Amrar and Bisharin families were allotted tenancies at the newly developed Suki scheme. The settlers were all placed in a new village. Problems with the levelling of the land resulted in 150 of the tenancies not being adequately irrigated and 130 families sold their tenancies to retourn to their original homes. The remaining tenants have apparently adjusted to their changed circumstances and run a cooperative shop, a flour mill and a bakery.

\section{Beja settlement 1972}

An attempt to settle several Beja on 3,000 feddans at Umm Barakeit village near the Ethiopian frontier has met only limited success. In spite of the provision of tractors about $80 \%$ of families returned to their original area over a short period. The $20 \%$ remaining have some rainfed cultivation but mainly practise cattle pastoralism.

\section{BIBLIOGRAPHY}

Abdel Ati H. A. - The impact of Khashm el Girba dam on thewestern lower Atbara area. Sudan. M. Sc. Econ. Thesis, University of Wales, 1979. (Unpublished).

Ali A.H.A. - The irrigated sub-sector of agriculture in the northern Region. In: ZAHLAN A.B. and MAGAR W.Y., ed. - The agricultural sector of Sudan. Policy and systems studies. London, Ithaca Press, 1986. P. 161-178.

Ali S.M. - The Ed Dueim pump scheme. B.A. Thesis. University of Khartoum. (undated) (Unpublished).

Baasher M., El Sammani M.O. - Report on development of pasture and fodder in eastern region. Rome, FAO, 1986. 
Barnett A. - The Gezira scheme. An illusion of development. London, Frank Cass. 1977.

Davies H.R.J. - An agricultural revolution in the African tropics: the development of mechanized agriculture on the clay plains of the Republic of Sudan.

Tijdschrift voor Economische en Sociale Geografie, 1964, 55 : 101-108.

Dirar A.R.M.A. - The economics of agricultural production in the private pump schemes - Kosti and Ed Dueim districts. M.A. Thesis. University of Khartoum, 1970. (Unpublished).

El Bashir A.S.A. - Mechanization, productivity and employment in large scale mechanized farms in the Sudan. Ph. D. Thesis. University of Kent, 1982.

Gaitskell A. - Gezira : a story of development in the Sudan. London, Faber and Faber. 1959.

Galal EI Din M.E. - Population and housing characteristics in villages of phase I of Rahad scheme. Ministry of Agriculture, Food and Natural Resources, 1974. (in Arabic).

Gibbon D., Harvey J. - Subsistence farming in the dry savanna of western Sudan. Savanna Development Project Phase II. 1977.

Habashi W. - The development of agricultural production in the Sudan. Lectures presented in arabic to the Department of Extra-Mural Studies. University of Khartoum, 1968.

Ibnouf M.A.O. - An economic analysis of mechanized food production schemes in the central plains of the Sudan. Ph. D. Thesis. Michigan State University, 1985. (Unpublished).

Idris H.A. - White Nile pump schemes. B.A. Thesis. University of Khartoum, 1960.

MAGAR W.Y. - The White Nile pump schemes. In: ZAHLAN A.B. and MAGAR Y.B., ed. - The agricultural sector of the Sudan. London, Ithaca Press, 1986. P. 179-191.

MFC (Mechanised Farming Corporation) - Task force report on revised role of the Mechanized Farming Corporation. Khartoum, MFC, 1984.

Ministry of Irrigation - Nile waters master plan summary. Khartoum, 1979.

MANR (Ministry of Agriculture and Natural Resources) (MANR) - Statement of strategy for rain-fed agriculture.

Khartoum, MANR, Agricultural Planning Administration, 1985.

Oesterdiekhoff P., Wohlmuth K., ed. - The development perspectives of the Democratic Republic of Sudan. The limits of the bread-basket strategy.

Munchen, Weltforum Verlag, 1983.

Rahad Corporation - Rahad irrigation project.

Khartoum, Rahad Corporation, 1977.

Shakkak K.I. - Mechanization of agriculture in the clay plains of the Sudan, with special reference to the Gedaref district. M. A. Thesis, University of Khartoum, 1977. (Unpublished).

Simpson I.G., Simpson M.C. - Alternative strategies for agricultural development in the central rainlands of the Sudan. University of Leeds, 1978. (Rural Development Study, n_3).

Simpson M.C. - Large-scale mechanized rainfed farming developments in the Sudan. In: Postindependence Sudan. University of Edinburgh, Centre of African Studies, 1981. P. 197-202.

Sudan Government - Irrigation by pumps from the Nile in the Sudan. Khartoum, Ministry of Irrigation, 1955.

Sudan Government - Report on the census of pump schemes. (June-August 1963). Vol. II, Part. 3. Khartoum Province. Khartoum, Department of Statistics, 1966.

Sudan Government - Strategy for development of rain-fed agriculture. Marketing, pricing and incentives. Khartoum, Sudan Government, 1986.

Suliman S.F.A. - A comparative study of three forms of organization of irrigated agricultural production in northern Sudan: a case study of the Shendi area. Ph. D. Thesis, University of Wales, 1988. (Unpublished).

Trilsbach A. - Agriculture west of the White Nile. In: DAVIES H.R.J., ed.- Rural development in White Nile Province, Sudan. Tokyo, United Nations University, 1986.

Wilson R.T. et al. - The cultivation cattle complex in western Darfur. Agricultural Systems, 1980, $5: 119-135$.

World Bank - Review of mechanised rainfed farming. 1983. 


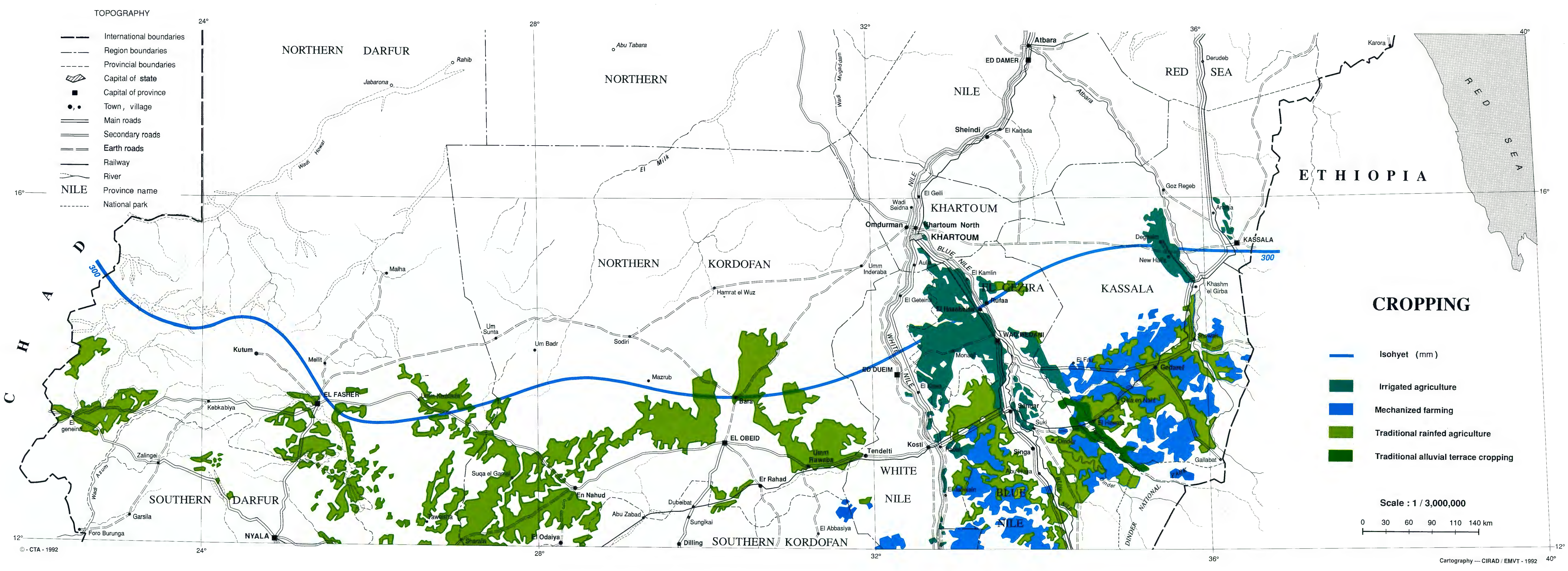




\section{LIVESTOCK WATER SUPPLY}

\section{H. TORRENT}

Torrent H., De Zborowski Isolde. 1993. Livestock water supply. In : Livestock production and sahelian rangelands potential: Republic of Sudan = Élevage et potentialités pastorales sahéliennes : République du Soudan. Darag A., Lamarque Georges. CIRAD-IEMVT - FRA. Wageningen : CTA-CIRAD-IEMVT, 23-24. ISBN 2-87614-088-8

The simultaneous availability of range and water is essential for pastoral development. The range and surface-water resources depend directly on the rainfall pattern. Groundwater resources depend not only on rainfall, but also on the infiltration and storage capacity of the ground.

As there are no permanent streams outside the Nile river, and as the rainy season lasts only a few months, the livestock water supply relies mostly on groundwater. Therefore, the availability of groundwater and its development through wells and boreholes are of great importance for livestock development.

The climate of the mapped area is subtropical to arid and is dominated by continental influences. Rainfall occurs mainly in summer and winter are dry. Rainfall varies from $600 \mathrm{~mm}$ in the southern part of the mapped area to less than $50 \mathrm{~mm}$ in the northern part. The interannual variability of rainfall is stronger towards the north. In recent years, Sudan has been affected by a prolonged drought; between 1965 and 1974, the annual average rainfall was $10 \%$ less than the average of the preceding 30 years, producing a southward shift in the isohyets of 75 to $100 \mathrm{~km}$.

Most of Sudan lies within the drainage basin of the Nile, which traverses the country from south to north. The Nile and its main tributaries, the Blue Nile and White Nile, are the only perennial watercourses. They have had a dominant influence on the economic and social history of the country, including of course the livestock sector.

At the confluence of the White and Blue Niles at Khartoum the Blue Nile contributes some $84 \%$ of the flow of the Nile and originates in the Ethiopian Highlands. The White Nile enters the southern border from Uganda and provides about $16 \%$ of the Nile flow. North of Khartoum, the Nile is joined by the Atbara, which also originates in Ethiopia, before crossing the Nabri desert into Egypt. In the south, the White Nile is joined from the west by the Bahr el Ghazal and Bahr el Arab; the upper reaches of the latter drain the eastern slopes of Jebel Marra (wadis Bulbul, Kaya, and Ghendi). Above the confluence with the Bahr el Ghazal, the white Nile is known as the Bahr el Jebel. An extensive area of swamp, the Sudd, occurs at this confluence.

Two other important watercourses enter Sudan from Ethiopia: Khor el Gash and Khor Baraka. Both have seasonal flood regimes. Khor Baraka enters the Red Sea at Tokar delta.

Several wadis drain the Red Sea Hills towards the Red Sea, including Khor Arbaat, Khor Mog and Khor Handoub. These have intermittent flow regimes.

Seasonal wadis in Darfur in west Sudan form part of the Chad basin. These include the Wadi Azum that drains the western slopes of Jebel Marra.

The dry northeastern part of the country lacks surface water. The flow of the seasonal rivers depends on rainfall that occurs spasmodically in the wet season and is often extremely intense and localized. The resulting river flows are similarly spasmodic, run off occurring for periods that can last from a few hours to several days. Between run off episodes, the rivers are usually dry for long spells, even during the wet season. Therefore, these floods do not constitute a reliable water supply for the livestock. About $75 \%$ of the livestock is reared by nomadic or semi-nomadic population, mainly in areas away from the Nile and thus depending extensively on groundwater supplies. 


\section{GROUNDWATER RESOURCES}

The distribution of the major groundwater units of the mapped area is shown on the hydrogeological map at scale 1/5,000,000 (Map 1). The major aquifers in order of decreasing importance are :

- the Nubian Sandstone formation,

- the Umm Ruwaba and associated formations,

- Alluvium and wadi fills,

- the Basement Complex.

The characteristics and potential of the aquifers are described in the legend as well as in the attached table. Map 2 provides more information on the twelve main sedimentary basins, concerning groundwater quality and flow directions. These basins have the highest potential for groundwater development and therefore a high pastoral potential. Groundwater development is more difficult and limited in the areas of Basement Complex, although modern investigation techniques should improve significantly the result of exploration in this kind of environment.

\section{WATER RESOURCES DEVELOPMENT FOR LIVESTOCK}

As said before, surface water cannot be a reliable resource away from the Nile river. However, rainfall and run off water is collected in numerous reservoirs constructed in clay, called "hafirs", or behind small dams.

Groundwater is extracted traditionally from dug wells, equipped or not with pumps. From the end of the sixties, groundwater has been developed for domestic and livestock water supply through the construction of thousands of "water yards". These consist of one or several drilled wells with sixinch casings and fitted with diesel pumps. The pumped water is stored in elevated tanks from where it flows to faucets to fill family buckets, and into three or four drinking troughs for livestock. The operation and maintenance of these three thousand or so "water yards", scattered on one million sq $/ \mathrm{km}$, turned out to be a very difficult task and many are now out over of order. Overgrazing around some of these sites is also a problem.

The locations of the water points (wells, boreholes, hafirs and dams) is plotted on the 1/500,000 scale rangeland maps, and their distribution is summarized on Map 3. Unfortunately no reliable information exists for eastern Sudan.

Table 1 - GENERAL HYDROGEOLOGICAL CHARACTERISTICS OF SELECTED ALLUVIAL AQUIFERS IN SUDAN

\begin{tabular}{|c|c|c|c|c|c|c|c|c|c|c|}
\hline \multicolumn{2}{|c|}{ BASIN } & $\begin{array}{l}\text { WELL } \\
\text { DEPTH (m) }\end{array}$ & $\begin{array}{c}\text { DEPTH } \\
\text { TO WATER } \\
\text { LEVEL }(\mathrm{m})\end{array}$ & $\begin{array}{c}\text { SPECIFIC } \\
\text { CAPACITY } \\
\left(\mathrm{m}^{2 / d}\right)\end{array}$ & TRANSMISSIVITY & $\begin{array}{l}\text { PERMEABILITY } \\
(\mathrm{m} / \mathrm{d})\end{array}$ & STORATIVITY & $\begin{array}{c}\text { ANNUAL } \\
\text { RECHARGE } \\
\left(10^{6} \mathrm{~m}^{3}\right)\end{array}$ & $\begin{array}{c}\text { ANNUAL } \\
\text { ABSTRACTION } \\
\left(10^{6} \mathrm{~m}^{3}\right)\end{array}$ & $\begin{array}{c}\text { TOTAL } \\
\text { DISSOLVED } \\
\text { SOLIDS (mg/l) }\end{array}$ \\
\hline KASSALA & K.EI GASH & 30 & 10 & 865 & 1000 & 40 & 0.13 & $170 / 240$ & 120 & $180 / 270$ \\
\hline DARFUR & $\begin{array}{l}\text { W. KUTUM } \\
\text { W. AZUM } \\
\text { W. ARIBO } \\
\text { W. NYALA } \\
\text { W. BULBUL } \\
\text { W. KAJA } \\
\text { W. IBRA }\end{array}$ & $\begin{array}{l}18 \\
38 \\
20 \\
17 \\
10,5 \\
25\end{array}$ & $\begin{array}{l}3.5 \\
3 \\
1.5 \\
2 \\
1.8 \\
1\end{array}$ & $\begin{array}{r}360 \\
2590 \\
2590 \\
865 \\
3025 \\
1030\end{array}$ & $\begin{array}{r}200 \\
1500 \\
1000 \\
600 \\
600 \\
1500\end{array}$ & $\begin{array}{l}14 \\
45 \\
50 \\
50 \\
65\end{array}$ & $\begin{array}{l}0.20 \\
0.20 \\
0.25 \\
0.20 \\
0.24\end{array}$ & $\begin{array}{l}20 \\
80\end{array}$ & $\begin{array}{l}0.05 \\
0.1\end{array}$ & $\begin{aligned} &<<150 \\
& 180 / 270 \\
&< 150 \\
&< 150 \\
&<150\end{aligned}$ \\
\hline NORD & $\begin{array}{l}\text { EI SELEIM } \\
\text { KERMA }\end{array}$ & $\begin{array}{l}<50 \\
<50\end{array}$ & $\begin{array}{l}6 \\
5.7\end{array}$ & $\begin{array}{l}3460 \\
5620\end{array}$ & $\begin{array}{r}500 \\
1050\end{array}$ & $\begin{array}{l}10 \\
12\end{array}$ & $\begin{array}{l}0.15 \\
0.15\end{array}$ & & & $\begin{array}{l}120 \\
120\end{array}$ \\
\hline
\end{tabular}

Source UNDP, 1987 
Table 2 - GENERAL HYDROGEOLOGICAL CHARACTERISTICS OF NUBIAN SUB-BASINS

\begin{tabular}{|c|c|c|c|c|c|c|c|c|c|}
\hline BASINS & $\begin{array}{l}\text { WELL } \\
\text { DEPTH (m) }\end{array}$ & $\begin{array}{l}\text { DEPTH } \\
\text { TO WATER } \\
\text { LEVEL(m) }\end{array}$ & THICKNESS & $\begin{array}{l}\text { WELL } \\
\text { YIELD } \\
\left(\mathrm{m}^{3} / \mathrm{d}\right)\end{array}$ & $\begin{array}{c}\text { SPECIFIC } \\
\text { CAPACITY } \\
\left(\mathrm{m}^{2} / \mathrm{d}\right)\end{array}$ & $\begin{array}{l}\text { STORAGE } \\
\left(10^{6} \mathrm{~m}^{* 3}\right)\end{array}$ & $\begin{array}{c}\text { ANNUAL } \\
\text { RECHARGE } \\
\left(10^{6} \mathrm{M}^{3}\right)\end{array}$ & $\begin{array}{l}\text { ANNUAL } \\
\text { ABSTRACTION } \\
\left(10^{6} \mathrm{~m}^{3}\right)\end{array}$ & $\begin{array}{l}\text { TOTAL } \\
\text { DISSOLVED } \\
\text { SOLIDS (mgl) }\end{array}$ \\
\hline $\begin{array}{l}\text { SAHARA } \\
\text { W. Howar } \\
\text { Atrum } \\
\text { Sanya Hayeih } \\
\text { Tima }\end{array}$ & $\begin{array}{l}37.5 \\
236 \\
96 \\
106\end{array}$ & $\begin{array}{l}6 \\
3,3 \\
53 \\
67\end{array}$ & $\begin{array}{l}300+ \\
200+ \\
100+ \\
50\end{array}$ & $\begin{array}{r}445 \\
490 \\
26 \\
145\end{array}$ & $\begin{array}{l}1470 \\
2420\end{array}$ & 400 & 27 & 3 & $54 / 134$ \\
\hline UMM KADDADA & & & & & & 600 & 100 & 10 & $80 / 666$ \\
\hline $\begin{array}{l}\text { Umm Bayada } \\
\text { Al Nusub }\end{array}$ & $\begin{array}{r}94 \\
106\end{array}$ & $\begin{array}{l}25 \\
74\end{array}$ & $\begin{array}{l}70+ \\
50+\end{array}$ & $\begin{array}{l}720 \\
390\end{array}$ & $\stackrel{-}{-}$ & & 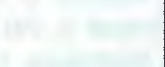 & & \\
\hline Umm Kaddada & 70 & 33 & $200+$ & 330 & 14 & & & & \\
\hline Shagg Mamda & 146 & 81 & $65+$ & 330 & 10 & & & & \\
\hline Shagera & 263 & 44,5 & 164 & 590 & 535 & & & & \\
\hline Sag EI Naam & 136 & 87 & $100+$ & 530 & 1730 & & & & \\
\hline Wad Banda & 232 & 94 & $250+$ & 120 & 20 & & & & \\
\hline Sug El Camal & 185 & 100 & $500+$ & 288 & 25 & & & & \\
\hline Fula & 241 & 98 & $2000+$ & 288 & 260 & & & & \\
\hline NAHUD & & & & & & 2 & 16 & 5 & $160 / 280$ \\
\hline Howag & 280 & 132 & $150+$ & 240 & 140 & & & & \\
\hline Saata & 310 & 95.4 & $200+$ & & 285 & & & & \\
\hline Cefauvi & 310 & 102 & 250 & 120 & 45 & & 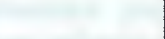 & & \\
\hline Maya & 357 & 111 & 250 & 120 & 25 & & 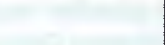 & & \\
\hline lyal Bakhit & 188 & 111 & $75+$ & 120 & 105 & & & & \\
\hline SAHARA NILE & & & & & & 600 & 175 & 35 & $200 / 700$ \\
\hline Khartoum & 65 & 20 & $100_{+}$ & 2040 & 345 & & & & \\
\hline Kerma & 245 & 6.2 & $500+$ & 6730 & 820 & & & & \\
\hline El Geleim & 311 & 14.6 & $500+$ & 3600 & 320 & & & & \\
\hline W. El Milk & 96 & 7.2 & $300+$ & 410 & 215 & . & & & \\
\hline GEDAREF & 130 & 50 & 206 & 385 & 10 & 76 & 40 & 8 & $940 / 2840$ \\
\hline BARA & & & & & & 45 & 15 & 4 & $80 / 4580$ \\
\hline UmmShelikeit & 233 & 400 & 91 & 132 & 47 & & & & \\
\hline Shawa & 226 & 600 & 45.5 & 132 & 121 & & & & \\
\hline Hedeid & 137 & 2 & $70+$ & 365 & 63 & & & & \\
\hline Umm Ushra & 233 & 600 & $200+$ & 384 & 104 & & & & \\
\hline Umm Sheila & 121 & 76 & $100+$ & 132 & 43 & & & & \\
\hline ATSHAN & & & & & & 23 & 70 & 20 & \\
\hline
\end{tabular}

BIBLIOGRAPHY

(main recent publications and groundwater studies)

MAP REFERENCE

NUMBER

ABDEL LATIF (M.A.M.) - 1976. Geology and hydrogeology of the sedimentary

10

basin of the Blue Nile and its tributaries between Wad Medani and Abu

Haggar. M. Sc. Thesis Univ. Khartoum, Geol. Dept.

ABDEL SALAM (Y.H.) -1966. The groundwater geology of the Gezira. M. Sc.Thesis Univ. Khartoum, Geol. Dept.

ABRAHAM (M.A.) - 1986. Geological, geophysical, hydrogeological investigations in Norther Kordofan.

AWAD (M.I.), FARWA (A.G.) and EI Sid (M.G.) -1986. A geological, geophysical and hydrogeological investigations in N. Kordofan. Univ. Khartoum, Geol. Dept.

BANNAGA (S.E.) - 1977. Study of water supply for El Obeid. Ph. D. Thesis Loughborough Univ. of Tech. (U.K.).

BGR - 1979. Groundwater resources in Khartoum province. Sudanese-German co-operative project. 

Sudan.

BRGM -1984. Rural water supply project in Western Sudan: water resources and requirements.

BRINKMANN (P.J.) et al. - 1987. Retrospective simulation of groundwater flow and transport in the Nubian aquifer system. Univ. of Berlin.

UNIV. OF BERLIN 1989. Groundwater study of North west area (on going study).

EDMUNDS (W.M.), DARLING (W.G.) and KINNIBURGH (D.G.) -1987. Estimation of aquifer recherche using geochemical techniques. Final report of Lower Atbara River basin project. British Geol. Survey.

EL BOUSHI (I.H.) and ABDEL SALAM (Y.) -1978. Stratigraphy and groundwater of the 9 Gezira area.

EL SAFIE (Y.E.A.) - 1975. Lithology of the Umm Ruwaba formation and its paleogeography in connection with water problem. Ph. D. Thesis Inst. Geol. Research (Moscou).

GEOTECHNICA-1985. El Obeid water supply project: feasibility study of groundwater resources.

GMRD, RSC, BRGM -1981. Geological map of the Sudan - scale 1/2,000,000. Ministry of Energy and Mines.

HOWARD HUMPHREY and Ptners 1983. El Fasher water supply. Final report.Ministry of Nat. Planning.

HOWARD HUMPHREY and Ptners - 1983. Nyala water supply. Final report.Ministry of Nat. Planning.

HUNTING GEOLOGY AND GEOPHYSICS Ltd and Mac DONALD, Sir M. and Ptners 1970. Water survey and development project in Darfur province. Report to RWC.

HUNTING TECHNICAL SERVICES Ltd and Mac DONALD, Sir M. and Ptners - 1976. Savannah development project, phase II. An. 2, part 1 Hydrogeology. Report to UNDP/FAO and Sudan Govt.

HUNTING TECHNICAL SERVICES Ltd - 1977. Agricultural development in the Jebel Marra area. An. 2, vol. 1 Hydrogeology - Report to UNDP/FAO and Sudan Govt.

HUNTING TECHNICAL SERVICES Ltd and Mac DONALD, Sir M. and Ptners -1974. EI

Obeid water supply: future development. Report to Nat. Planning Commission.

INSTITUTE of hydrology -1978. El Obeid water supply expansion: a review of the groundwater potential of the Bara and Nahud Basins. 


\section{LIVESTOCK WATER SUPPLY (CONTINUED)}

KHEIRALLA (M.K.) 1966. A study of the Nubian Sandstone formation at the Nile valley between

lat. $14^{\circ} \cdot \mathrm{N}$ and $17^{\circ} \cdot 42^{\prime} \mathrm{N}$, with reference to the groundwater geology. Univ. Khartoum, Geol. Dept.

KOTOUB (S.) - 1987. Hydrogeological investigations of the Nubian Sandstone formation, Lower Atbara basin. Final report. ACSAD Damascus.

NCDRWR, TNO-DGV -1989. Hydrogeological map of Sudan. Scaie 1/2,000,000.

MABROOK (B.M.A.) - 1972. Geologic and hydrogeologic studies of East Kordofan area. M. Sc. Thesis Univ. Khartoum, Geol. Dept.

MOHAMED (A.R.M.) - 1975. The hydrogeology of Shagera basin with reference to the water supply of El Fasher town. M. Sc. Thesis Univ. Khartoum, Geol. Dept.

REGWA and RWC - Sudan anti-thirst project. 1969, 1 -Blue Nile province. 1972, 2 -Kordofan province. 1972, 3-Khartoum province. 1972, 4-Darfur province.

REGWA and RWC -1977. Final report for Hydrogeological study of Ed Dueim area. 2 -

Geophysical survey. 
REGWA - 1977. Groundwater study of West of Khartoum area.

RURAL WATER CORPORATION -1976. Hydrogeological map of Sudan: piezometric surface, water quality - scale 1/4000 000 .

RURAL WATER CORPORATION - 1976. Structural-hydrogeological map, western map of Kordofan province and eastern part of Darfur province.SAEED (E.T.M.) -1972. Hydrogeology of Kassala district, Kassala province. Geol. Survey Dept, bull. 21 (2).

SAEED (E.T.M.) - 1976. Hydrogeology of Khartoum province and Northern Gezira area. Geol. Survey Dept. bull. 29.

SANOUSSI (M.H.) -1982. Gedaref water supply. M. Sc. Loughbourough Univ..

SIR ALEXANDER GIBB and Ptners - 1989. Sub-Saharan Africa Hydrological assessment (Group I countries) final report. Sudan. British Geol. Survey and IH.

SHAFI (M.A.) -1980. Hydrogeological and environmental isotope studies at Buran, Darfur.

STROJEXPORT - 1969-1976. Geophysical investigation of hydrogeological structures (central and western part of Kordotan province) 
SULEIMAN (Y.) - 1968. The hydrogeology of part of Eastern Sudan (Gedaref district). Geol. Survey Dept. bull. 16 .

TNO, RWC -1978. Water ressources and water supply of Sudan's Kosti/Jebelein area.

TNO, NWC - 1982. Kassala Gash basin, final technical report.

TNO-DGV, NWC - 1985. Nyala water ressources: final report.

TNO-RWC - 1984. Water resources of the Gedaref area.

TNO-DGV, NWC - 1985. Geneina water resources study, final report.

TNO-DGV - 1987. Water resources assessment and development project inSudan: plan of operations $1987-1989$.

TNO-DGV, RWC - 1989. Groundwater study of South Darfur area (on going study)

YASSIN (A.A.), KHALID (F.A.) - 1984. Explanatory note to the geological map at the scale of $1 / 2,000,000$ of the Democratic Republic of Sudan. Geol. and Min. Res. Dept. bull. 35.Legende des cartes $1 / 500,000$. 

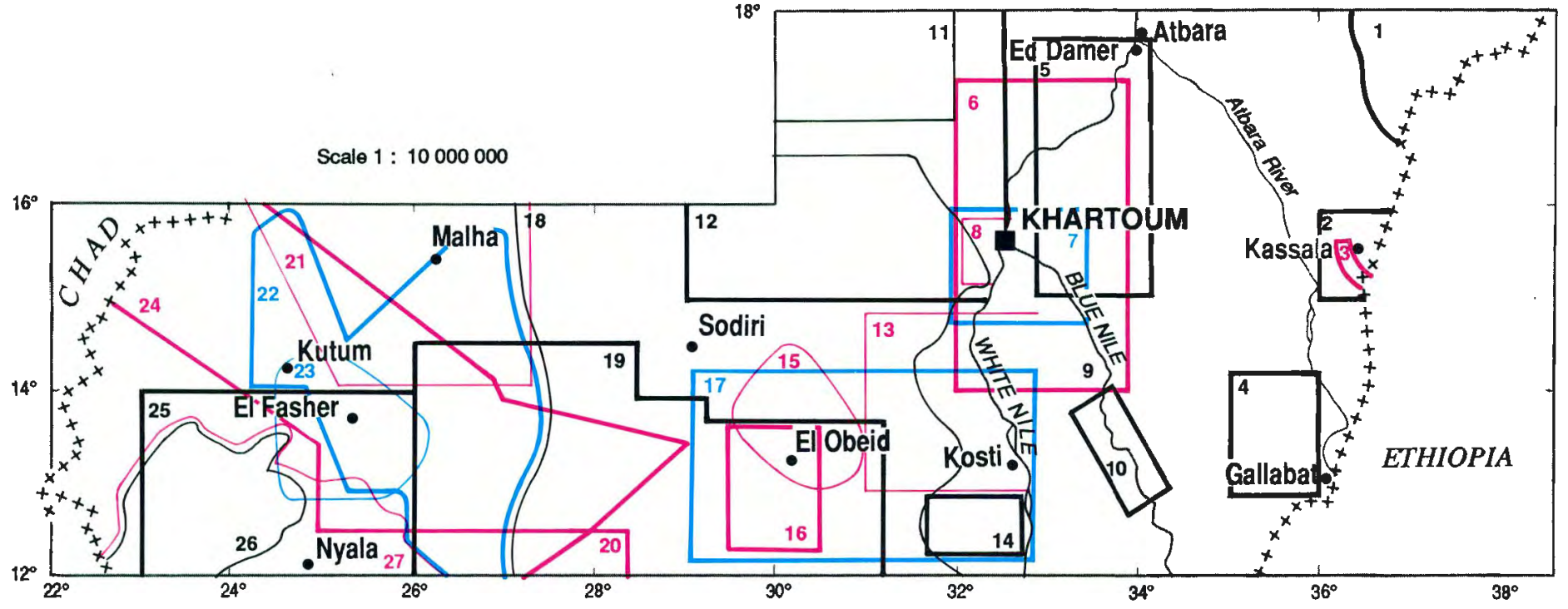
MAP 1 : HYDROGEOLOGICAL MAP

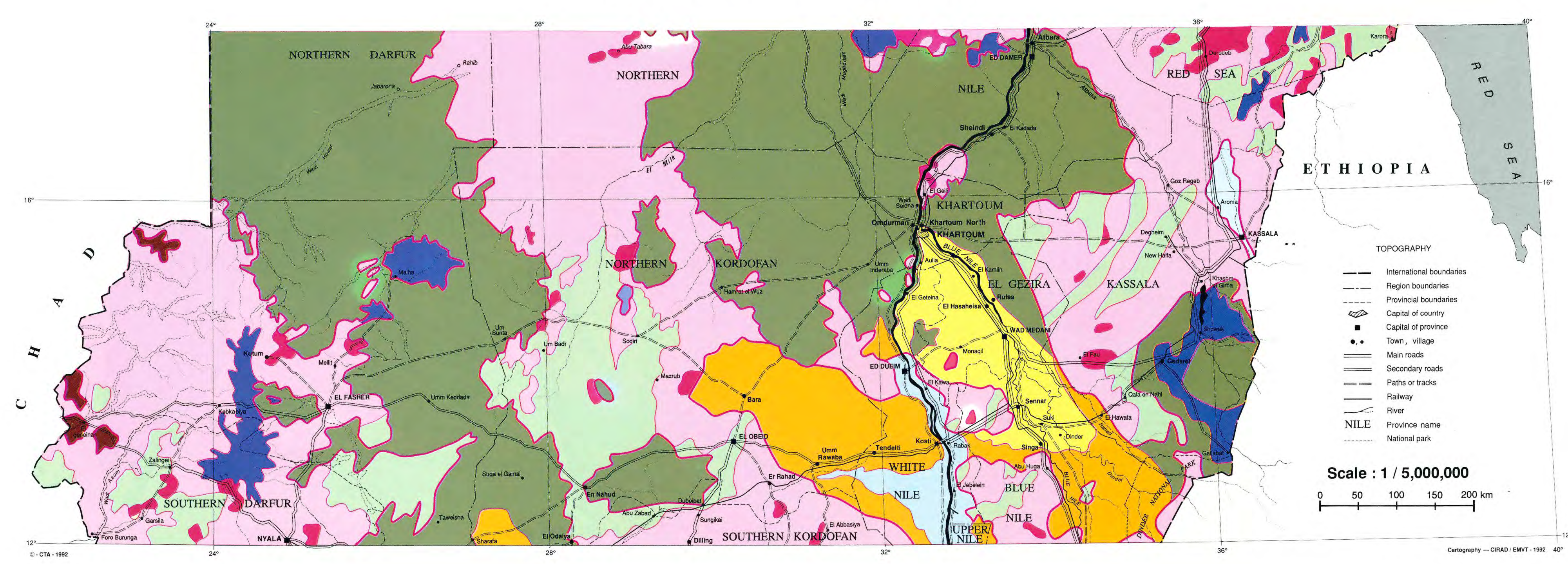

\begin{tabular}{|c|c|c|c|c|c|}
\hline & STPATGGAAHY & LITHOLOGY & \multicolumn{2}{|c|}{ 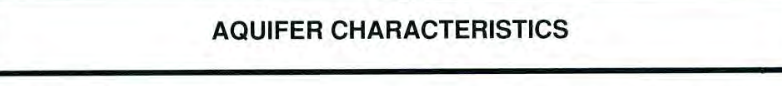 } & CATCHEENT WOOKS \\
\hline & RECENT & 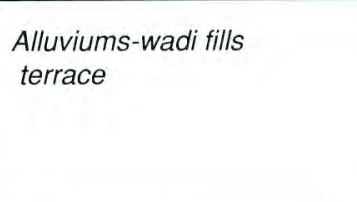 & \multicolumn{2}{|c|}{ 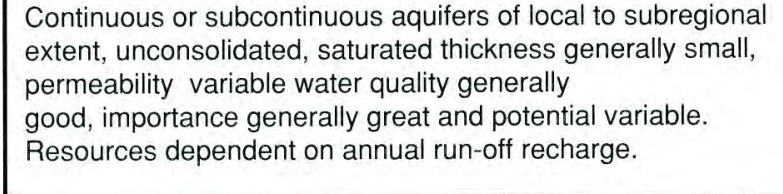 } & Shallow wells (SWL O-10 m) \\
\hline & 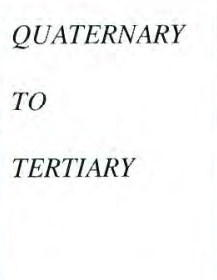 & 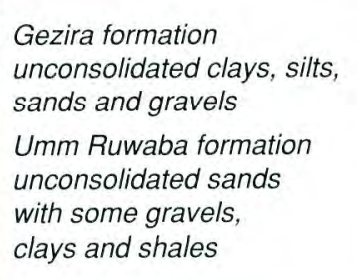 & \multicolumn{2}{|c|}{ 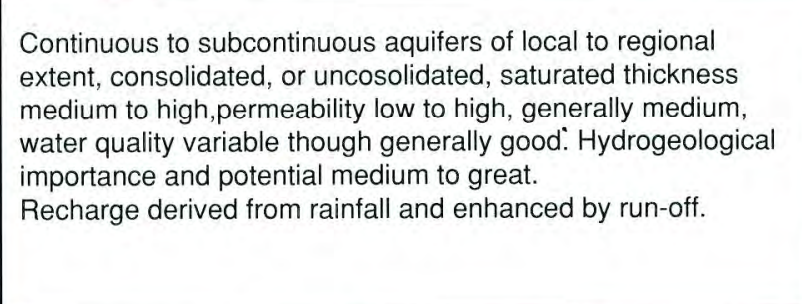 } & 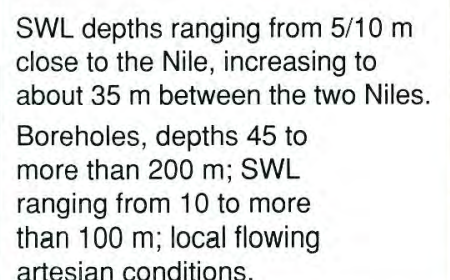 \\
\hline & CRETACEOOUS & 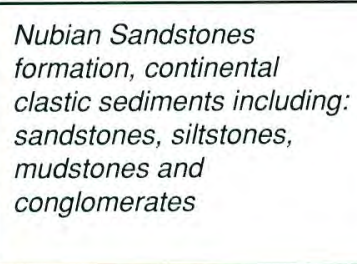 & \multicolumn{2}{|c|}{ 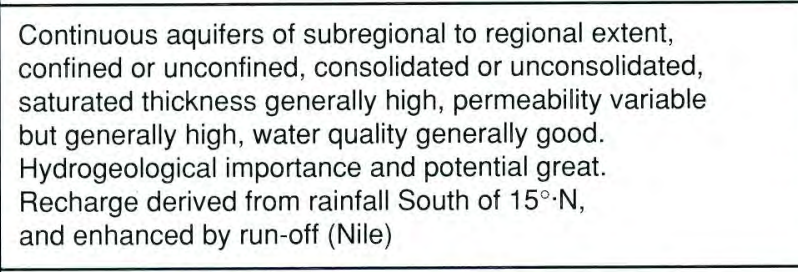 } & 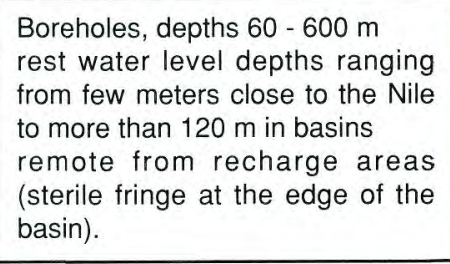 \\
\hline & PAIEOOOOCC & 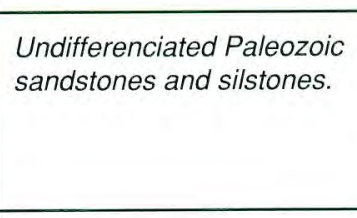 & \multicolumn{2}{|c|}{ 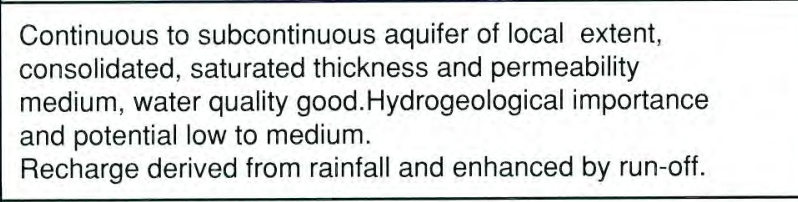 } & 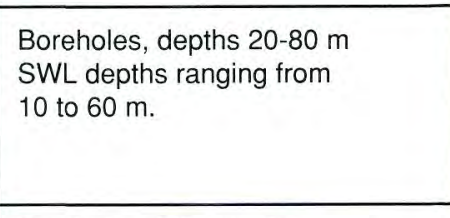 \\
\hline & 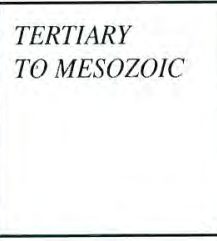 & 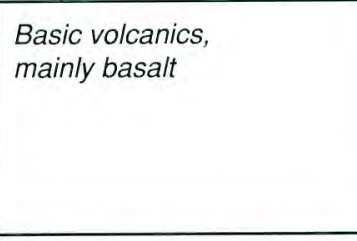 & \multicolumn{2}{|c|}{ 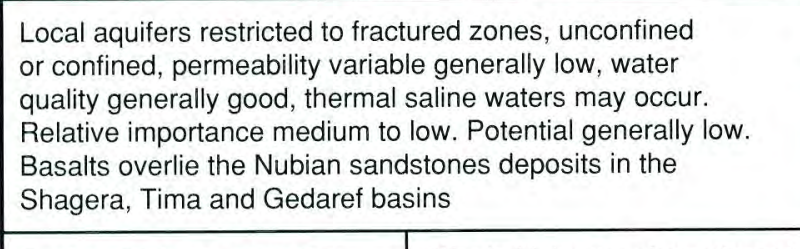 } & 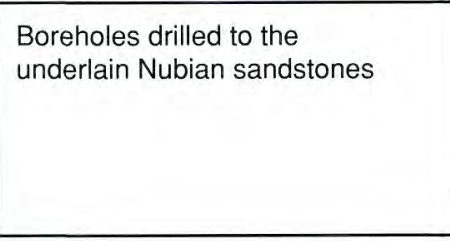 \\
\hline & PROTEREOOOC & 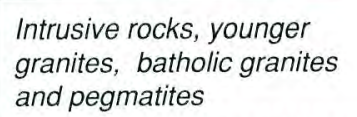 & \multirow{3}{*}{ 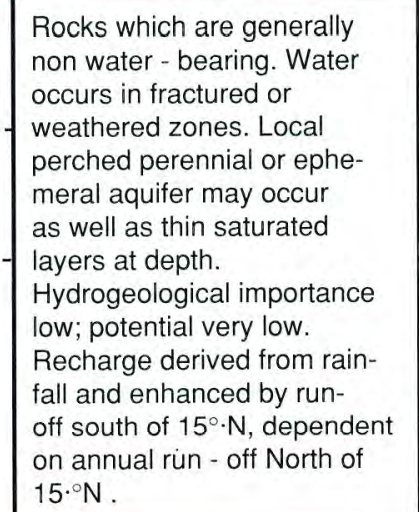 } & 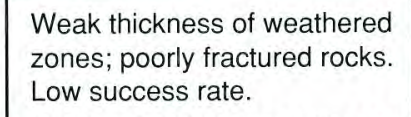 & 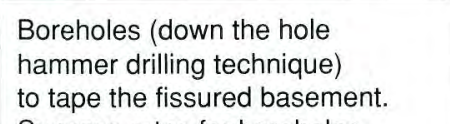 \\
\hline & PROTEROOOOCC & 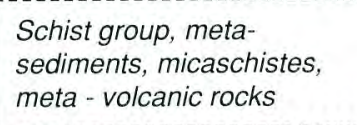 & & 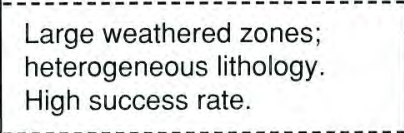 & 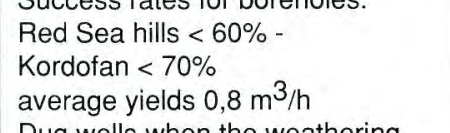 \\
\hline & 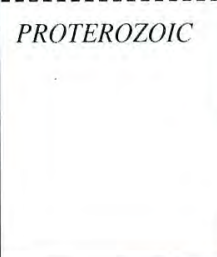 & 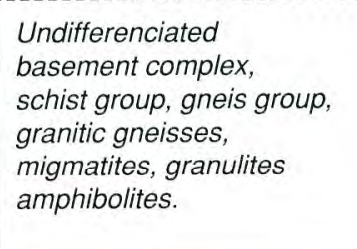 & & 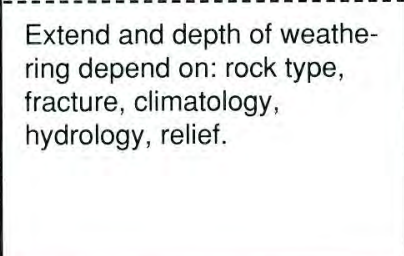 & \\
\hline
\end{tabular}

MAP3 WATER RESOURCES DEVELOPMENT

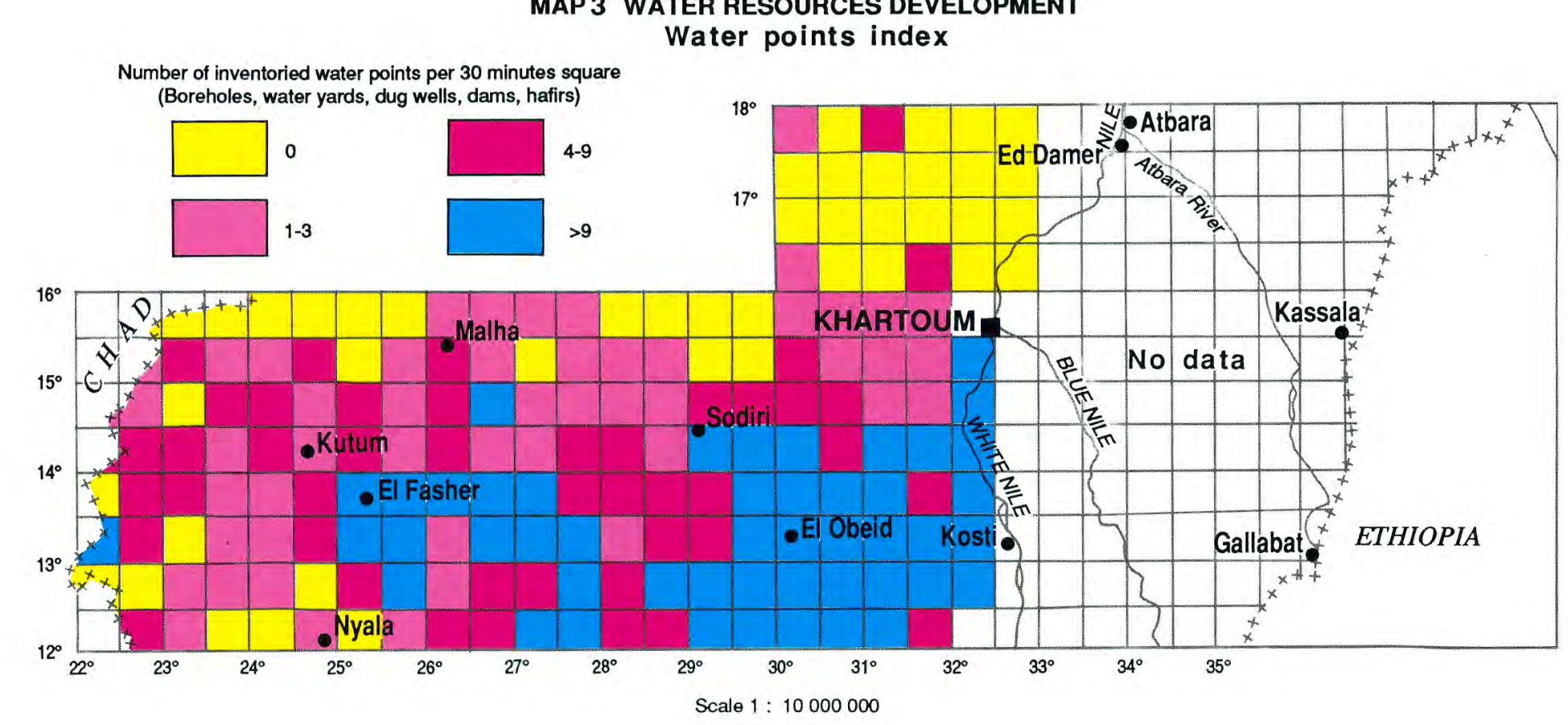




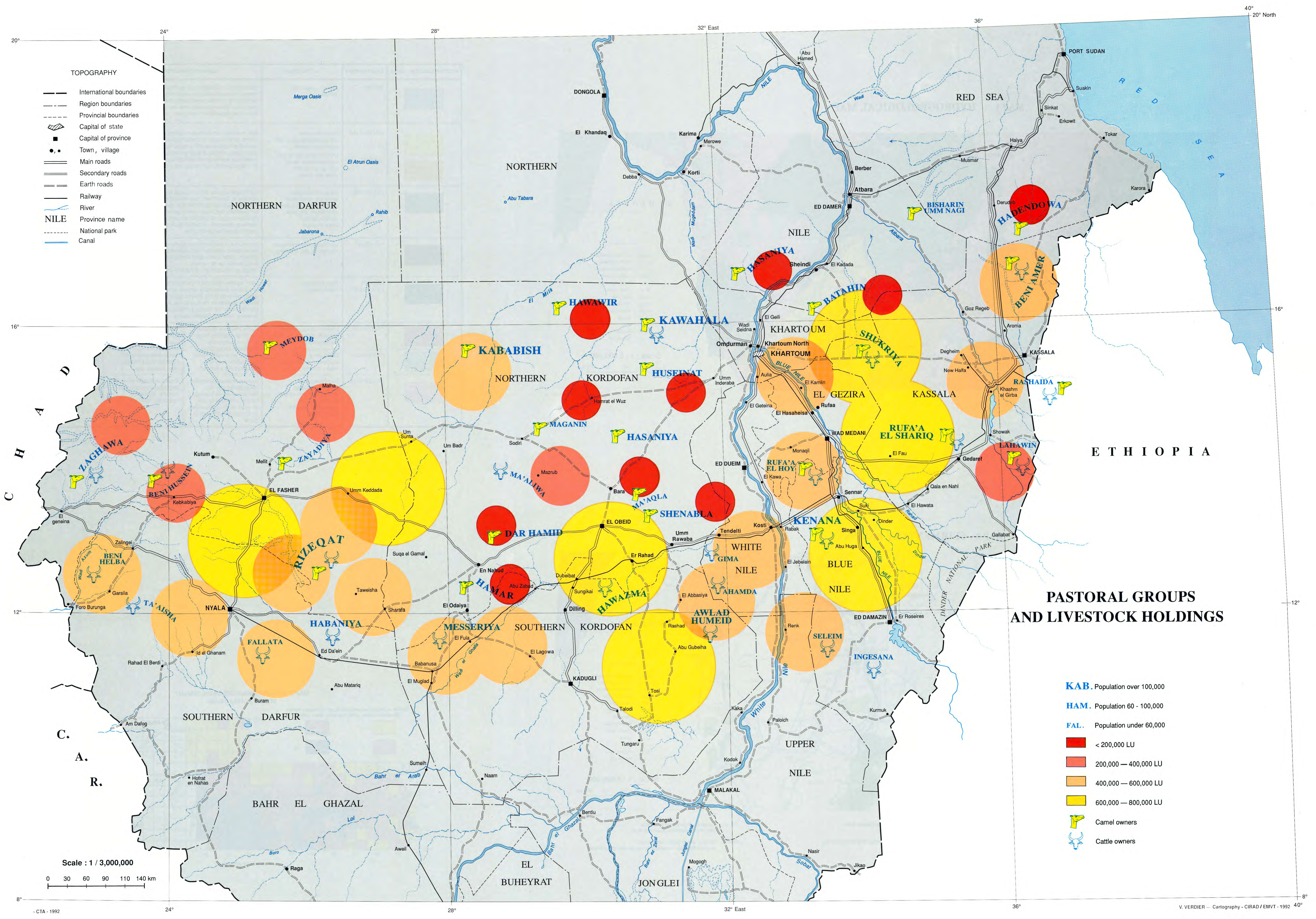


Pastoral production and economy. El Sammani M.O., Verdier Véronique. 1993. In : Livestock production and sahelian rangelands potential: Republic of Sudan = Élevage et potentialités pastorales sahéliennes : République du Soudan. Darag A., Lamarque Georges. CIRAD-IEMVT - FRA. Wageningen : CTA-CIRAD-IEMVT, 25-27. ISBN 2-87614-088-8

Two major specialist groupings can be distinguished in the pastoral zone of the Sudan that extends from $10^{\circ} \mathrm{N}$ to $18^{\circ} \mathrm{N}$. These groupings are:

- the "abbala" or camel-owning group, who also herd sheep and goats but who have no or very few cattle;

- the "baggara" or cattle group ( the term is extended here to cover all cattle raising groups, inrespective of ethnics belongings), also with sheep and goats and very small numbers of camels.

There are several tribes in each group, a tribe being defined as an integrated and autonomous political and social unit. Affinities among tribes of the same specialization exist through historical and blood ties. The camel tribes own fewer camels per head of population than do the cattle ones but slightly more sheep and goats (Table 1). 
Table 1 - Livestock numbers per head of population for the two major pastoral groupings

\begin{tabular}{|c|c|c|c|c|c|}
\hline \multirow{2}{*}{ Owning group } & \multirow{2}{*}{$\begin{array}{c}\text { Human } \\
\text { population } \\
\left(10^{6}\right)\end{array}$} & \multicolumn{4}{|c}{ Animals per person } \\
\cline { 3 - 6 } & 1.48 & 2.16 & & 6.91 & 3.25 \\
\hline $\begin{array}{c}\text { Camels } \\
\text { (abbala) }\end{array}$ & 1.26 & & 9.10 & 5.08 & 1.44 \\
\hline $\begin{array}{c}\text { Cattle } \\
\text { (baqqara) }\end{array}$ & & & Cattle & Sheep & Goats \\
\hline
\end{tabular}

The human population of the Sudan was estimated at 26.48 million with the pastoral tribes accounting for 2.83 million (Table 2). Most pastoralists, who can be ascribed to 38 major and many minor tribes (Table 3), inhabit Kordofan (25\% of the total population), with large proportions in Eastern (23\%) and Darfur (18\%) regions and smaller ones in Central $(6 \%)$, Northern $(4 \%)$ and 
Table 2 - Distribution of the human population (million) of the Sudan in 1990

\begin{tabular}{l|c|c|c|c}
\hline \multicolumn{1}{c|}{ Region } & Pastoral & Rural & Urban & Total \\
\hline South & 0.00 & 5.93 & 0.86 & 6.79 \\
Central & 0.34 & 3.58 & 1.23 & 5.15 \\
Darfur & 0.72 & 2.79 & 0.48 & 3.99 \\
Kordofan & 1.02 & 2.38 & 0.57 & 3.97 \\
Eastern & 0.65 & 1.23 & 0.98 & 2.86 \\
Khartoum & 0.05 & 0.43 & 1.84 & 2.32 \\
Northern & 0.05 & 1.11 & 0.24 & 1.40 \\
Total & 2.83 & 17.45 & 6.20 & 26.48 \\
\hline
\end{tabular}


Khartoum (2\%) Regions. In total the pastoral population is equivalent to almost $11 \%$ of all the Sudanese people, compared to $23 \%$ in urban areas and $66 \%$ non-pastoral rural dwellers.

The pastoral population has increased in numbers at an annual rate of $3.6 \%$ over the last 35 years. The proportion of pastoralists in the total population has, however, declined from $13.2 \%$ t to $10.2 \%$.

\section{The Abbala}

Camel production is an activity of the arid and semi-arid north of the country.

In Kassala Province the plains around Kassala town, the strip extending from the Atbara river valley to the Ethiopian border and the central Butana neighbouring Gezira and Khartoum Provinces are the main camel herding areas. The Hadendowa, Beni Amer, Rashaida, Bisharin,

Shukriya, Lahawin, Bawadra, Kawahla and Ahamda own at least 1.15 million camels, 4.23 million sheep and 0.80 million goats.

In Northern Kordofan the northern sandy semi-desert areas, the sandy "qoz", the "gardud" sandy and clay pediplains and the gum belt are the strongholds of camel production. The Kababish, Kawahla, Hawawir, Hamar, Shanabla, Dar Hamid and other tribes of the region raise 1.16 million camels, 2.84 million sheep and 2.10 million goats.

Camel production is practised in areas in Northern Darfur that have similar ecology to those in Kordofan. There are many tribes involved, the main ones being the Meidob, the Zaghawa, the 
Zayadiya and parts of the Rizeiqat. Camel numbers are smaller in Darfur, 0.69 million, than in the other Provinces and they are accompanied by 2.62 million sheep and 1.46 million goats.

Camel owning groups comprise about 1.48 million people, $48 \%$ of whom are found in Northern Kordofan, $35 \%$ in Kassala and $16 \%$ in Northern Darfur with the remaining $1 \%$ scattered in other northern provinces. With the exception of the Kababish, camel-owning tribes that do not keep cattle are small with an average of about 60,000 people owning in the region of 100,000 camels and about four times as many small ruminants.

The majority of camel tribes are Arabs. Those which are not (e.g. the Beja) have been strongly influenced by Arab culture and religion, and are Muslim and speak Arabic, beside their indigenous language. The exceptions are the western Meidob and Zaghawa who, in particular, have retained much of their own languages.

Animals are raised for subsistence and to provide products for sale or exchange. Cereal grains are the principal commodity that camel tribes need to import into their economies. In the past, in addition to providing material sustenance, animals were a source of prestige for the owner. Traditional attitudes to production are changing and a more market oriented production system is gradually developing.

Differences in wealth are evident among the abbala. The majority of families own some 30 camels 


\section{PASTORAL PRODUCTION AND ECONOMY (CONTINU}

and 100-300 head of small ruminants. Families with larger numbers of each species are "rich", those with smaller numbers are "poor". Small ruminants are the category of stock which provides most of the interchange within the system, at least until enough are acquired to convert into the more desirable camels.

\section{Production systems}

Camel owning groups are pastoralists in that livestock provide their main wealth and subsistence. Grain, usually bulrush millet but sometimes sorghum in wadi beds is occasionally grown in favourable places or in good years: most grain is acquired by purchase or exchange, however. In times of low animal productivity, or when gum prices are high, then gum is tapped by some pastoralists to provide additional income.

The traditional way of life is being steadily eroded under modern influences. Induced and spontaneous settlement is taking place, perhaps more so in Kassala than in the western provinces. It is estimated that the percentage of animals owned by the abbala has been reduced from about 85 in 1970/1971 to about 60 in 1989/1990. Semi-nomadism or transhumance is associated with rainfed cultivation and with access to crop residues on the large state - and privately - owned agricultural schemes.

Table 3 - Pastoral tribes: human and livestock population numbers ('000)

\begin{tabular}{|c|c|c|c|c|}
\hline \multirow{2}{*}{ Tribe } & \multirow{2}{*}{ People } & \multicolumn{3}{|c|}{ Livestock } \\
\hline & & Camels & Cattle & $\begin{array}{l}\text { Sheep + } \\
\text { Goats }\end{array}$ \\
\hline Ahamda & 40 & & 440 & 515 \\
\hline Awlad Humeid & 88 & & 725 & 636 \\
\hline Batahin & 65 & 117 & & 304 \\
\hline Beni Amer & 94 & 164 & 210 & 453 \\
\hline Beni Halba & 55 & & 395 & 115 \\
\hline Beni Hussein & 35 & 80 & 198 & 86 \\
\hline Bisharin umm Nagi & 32 & 58 & & 96 \\
\hline Dar Hamid & 71 & 112 & & 465 \\
\hline Fellata & 60 & & 425 & 125 \\
\hline Gima & 40 & & 440 & 515 \\
\hline Habbaniya & 75 & & 548 & 150 \\
\hline Hadendowa & 78 & 65 & & 215 \\
\hline Hamar & 73 & 112 & & 632 \\
\hline Hasaniya & 75 & 122 & & 481 \\
\hline Hawawir & 73 & 109 & & 479 \\
\hline Hawazma & 92 & & 654 & 279 \\
\hline Huseinat & 74 & 118 & & 578 \\
\hline Ingessana & $?$ & & $?$ & $?$ \\
\hline Kababish & 172 & 340 & & 1278 \\
\hline Kawahla & 127 & 253 & 118 & 1697 \\
\hline Kenana & 110 & 42 & 615 & 749 \\
\hline Lahawin & 40 & 100 & 95 & 865 \\
\hline Ma*aliya & 30 & & 210 & 60 \\
\hline Ma*aqla & 15 & 15 & & 75 \\
\hline Maganin & 25 & 70 & & 425 \\
\hline Messeriya Humf & 95 & & 855 & 288 \\
\hline Messeriya Zuruq & 85 & & 604 & 258 \\
\hline Meidob & 60 & 171 & & 989 \\
\hline Rashaida & 98 & 305 & 154 & 873 \\
\hline Rizeiqat & 180 & 86 & 2580 & 1234 \\
\hline Rufa'a el Hoi & 58 & 50 & 415 & 781 \\
\hline Rufa'a el Shariq & 92 & 104 & 510 & 791 \\
\hline Seleim & 49 & & 488 & 746 \\
\hline Shenabla & 76 & 118 & & 463 \\
\hline Shukriya & 83 & 165 & 317 & 1549 \\
\hline Ta'aisha & 70 & & 504 & 140 \\
\hline Zaghawa & 75 & 155 & 42 & 1274 \\
\hline Zayadiya & 50 & 143 & & 850 \\
\hline Minor tribes & 120 & 210 & 125 & 1741 \\
\hline Total & 2830 & 3200 & 11487 & 23250 \\
\hline
\end{tabular}

Camel herders who also cultivate do this either on private land or in some of the major development projects. The Beja, for example, grow "dura" or sorghum in wadi beds and on the terraces during the short flood periods that prevail in the Red Sea hills. In addition, some Beja have tenancies in the Gash and Baraka schemes where in addition to cereals (including Sorghum or bulrush millet in the Baraka) they grow cotton and castor as cash crops. 
The Butana tribes have a similar system, some growing cereals on small plots near their settlements or cultivating as tenants on the New Halfa scheme: some of the richer members of these tribes own small mechanized farms. In Darfur and Kordofan the abbala tribes grow some "dukhn" in the southern parts of their respective "dar".

Livestock and crops, while not completely integrated as a system, complement each other. Some animals are sold every year to raise cash for household goods and even to buy feed or medicines for the other animals. The type and number of animals sold varies according to the needs and to the owners' perceptions of herd structure.

\section{Community and individual wealth}

Although there are 18 important tribes whose main wealth is camels $49 \%$ of the people involved and $51 \%$ of the camels are in five tribes or tribal groups. These five tribes, however, own only $36 \%$ of the sheep and $39 \%$ of the goats of the total of these species that belong to the abbala. The five groups in question are the Beja (Hadendowa, Amarar, Bisharin and Beni Amer), the Kababish, the Rashaida, and the Meidob and the Zaghawa.

The concept of individual wealth can be related to the numbers and types of animais that a family owns. A family obviously varies in size but is normally considered to average seven people, these being the head of the house and his wife, two married sons and one unmarried son or daughter. "Rich" Baja, for example, own somewhere in the region of 50 camels (Table 4), while rich Rashaida own 400 and even a "poor" Rashaida owns an average of 40 camels. In total the Beja tribes, who comprise about $23 \%$ of camel owners, own about $19 \%$ of all the camels belonging to the "abbala" and slightly over $18 \%$ of sheep and goats combined. The Kababish comprise about $12 \%$ of the people, own $11 \%$ of the camels and $17 \%$ of the small ruminants. The Rashaida are the richest of the camel tribes: they amount to $5 \%$ of the people but own $10 \%$ of the camels although they are not so well off in small ruminants, owning only $8 \%$ of these animals. The Zaghawa $(5 \%$ of people, $7 \%$ of camels and $17 \%$ of sheep and goats) and Meidob ( $4 \%$ of people and $5 \%$ and $14 \%$ of camels and small ruminants) are intermediate in standing.

\section{The "Baggara"}

Cattle husbandry is practised in areas that are less harsh than those where camels are found. As a consequence the migratory patterns of the baqqara tribes are less extensive than those of the "abbala". The annual rainfall in the "cattle belt" is seldom less than $500 \mathrm{~mm}$ and animal husbandry is frequently associated with crop production.

Southern Darfur is a major cattle raising area, the principal tribes here being the Rizeigat, the Habbaniya, the Ta'aisha, the Beni Halba, the Beni Hussein and the immigrant Fellata. The total population of 410,000 in these tribes represents $83 \%$ of the Province's cattle nomads and $33 \%$ of all such in the Sudan.

In Southern Kordofan it is the Messeriya (both Humr and Zuruq), the Hawazma and the Awlad Humeid that are the principal tribes. Their population amounts to 272,000 , this being $86 \%$ of Southern Kordofan cattle nomads and $22 \%$ of all those in the Sudan. The Awlad Humeid are also found in White Nile as are the Seleim, Ahamda and Gima people, as well as part of the Kenana. These tribes comprise almost the totality of cattle nomads here and are equivalent to $17 \%$ of Sudanese cattle nomads.

In Blue Nile the dominant tribes are Rufa'a el Hoi, Rufa'a el Shariq, the Kenana and the Kawahla. Kenana people also inhabit Kassala Province as do the Shukriya: some of the camel-owning groups also have comparatively large numbers of cattle. Numbers of cattle nomads are smaller in both these Provinces. The tribes listed total 121,000 in Blue Nile and 124,000 in Kassala and are respectively $97 \%$ and effectively $100 \%$ of cattle nomads there, equivalent to $9 \%$ and $10 \%$ of all the Sudan's cattle nomads. 
These five major areas of cattle production are thus home to 1.26 million baggara people who collectively own 11.47 million cattle, 6.40 million sheep and 1.81 million goats. The majority of the baqqara are of Arab origin, the major exception being the Fellata who are recent immigrants from West Africa. Penetration by the baqqara southward into the savanna belt has resulted in some admixture of indigenous African blood into the people: they remain, however, for the most part faithful to Islam and use Arabic as the mother tongue.

The baggara were able to escape some of the worst effects of the 1984 drought. This applies particularly to those living in Blue and White Nile Provinces as they were able to retreat to the better-endowed riverain areas.

\section{Production systems}

The baggara are pastoralists by the same definition as are the abbala, in that almost all their wealth and most of their income derives from livestock. They are less mobile than the camelowning group, most are in fact semi-settled or many even have at least part of the family fully settled. Strictly speaking it would probabiy be more appropriate to refer to them as transhumants rather than as nomads.

The cultivation of cereals, especially "dukhn", is a widespread practice among the cattle people. In Kassala the "dukhn" is often replaced with "dura". Many families particularly in Darfur region also collect gum on a regular basis and many own gum trees and actively promote their regeneration and growth. Crop residues, from own fields and from the large scale developments, are an important source of dry season livestock feed.

Table 4 - Distribution of families (average of seven members) by wealth ranking in some camel-owning pastoral tribes

\begin{tabular}{|c|c|c|c|}
\hline \multirow{2}{*}{$\begin{array}{l}\text { Tribe } \\
\text { and } \\
\text { Livestock species }\end{array}$} & \multicolumn{3}{|c|}{ Wealth rank (Number of animals) } \\
\hline & Fich & Average & Poor \\
\hline \multicolumn{4}{|l|}{ Beja: } \\
\hline Camels & 50 & 20 & 5 \\
\hline Sheep & 70 & 40 & 15 \\
\hline Goats & 45 & 25 & 10 \\
\hline \multicolumn{4}{|l|}{ Kababish: } \\
\hline Camels & 300 & 100 & 20 \\
\hline Sheep & 300 & 100 & 20 \\
\hline Goats & 90 & 50 & 20 \\
\hline \multicolumn{4}{|l|}{ Rashaida: } \\
\hline Camels & 400 & 200 & 40 \\
\hline Sheep & 50 & 35 & 20 \\
\hline Goats & 12 & 8 & 5 \\
\hline \multicolumn{4}{|l|}{ Zaghawa and Meidob: } \\
\hline Camels & 270 & 135 & 25 \\
\hline Sheep & 320 & 110 & 25 \\
\hline Goats & 150 & 100 & 75 \\
\hline \multicolumn{4}{|l|}{ Other tribes: } \\
\hline Camels & 300 & 100 & 20 \\
\hline Sheep & 310 & 105 & 22 \\
\hline Goats & 100 & 65 & 50 \\
\hline
\end{tabular}

Many baggara also engage in irrigated or mechanized agriculture either on private land or as tenants on the large schemes. There is a continuing tendency by all tribes to become more involved in commercial production of crops as well: some examples include cotton by the Hawazma, groundnuts by the Messeriya and mechanized sorghum by the Rufa'a el Hoi and the Kenana. 
There is also a gradual transition to more commercial livestock production among the baqqara, as among the abbala. Some rear cattle with more commercial ends than their fellows and rely on goats for the provision of household milk and meat. Subsistence is still provided by animals but cash raised from their sale or the sale of their products is spent on domestic needs or on consumer goods or is used to pay taxes. Some cash may be recirculated into the herd by purchase of breeding females. Decisions on which animals to be sold are usually made by the household head. Both cattle and sheep are sold but the relative proportions of each vary in the several provinces and among the tribes.

\section{Community and individual wealth}

While camels are the main wealth of the abbala they comprise only $18 \%$ of total animal numbers, with sheep contributing about $56 \%$ of numbers and goats about $26 \%$. In contrast the baggara cattle amount to $58 \%$ of all animals owned by the group, sheep are a further $32 \%$ and goats about $10 \%$. Individually and collectively the total number of animals kept by baqqara is more than that kept by abbala. Numbers alone, however, should not be considered to be true indicators of real wealth as the relative values of the species in money and production terms are certainly more important.

The 27 major cattle tribes, together with the minor tribes that are also classed as baqqara collectively own 11.5 million cattle, 6.40 million sheep and 1.81 million goats. The Rizeiqat are the major tribe in Southern Darfur and own $52 \%$ of the provincial cattle and $51 \%$ sheep. In Southern Kordofan some $80 \%$ of cattle and $85 \%$ of sheep are owned by the two Messeriya tribes and the Hawazma. In the other provinces livestock wealth is relatively evenly distributed among the tribes.

At the level of the family there are differences in wealth of a type similar to that noted for the abbala. Inequalities between "rich" and "poor" are however more evident in the two western provinces than in the east (Table 5).

The Rizeiqat are the richest individuals overall: they constitute only $12 \%$ of all baqqara but own $22 \%$ of the cattle and $11 \%$ of the sheep owned by the group as a whole. The Seleim, the Ahamda, the Gima, the Rufa'a el Hol and the Rufa'a el Shariq own marginally greater proportions of cattle than are their representation in human numbers but these tribes plus the Kenana and the Awlad Humeid are relatively richer in sheep.

\section{Social organization}

Clear roles and functions in the production process can be discerned at the levels of the tribe, the sub-tribe and the household.

\section{The tribe}

In the past the tribe was a more autonomous and integrated entity than it is at present. The identity of the tribe was supported and reinforced in many ways, through traditional leadership within the unit itself, and prominent members of it being elected or appointed as local and regional councillors and sometimes assuming high office in government itself.

Success was always mixed with some measure of failure. At the regional level the tribe may often have been supreme. Equally often, perhaps, the self-interest of the traditional leadership overrode that of the tribe as a whole. On occasions an overriding national interest was forced on the tribe by the central autocracy from Khartoum.

The importance of these roles and these factors is now diminished but the tribe still acts, however, as the spatial and cultural unit. Tribal cohesion and self-expression is maintained in:

retaining the nominal right to the "dar" (in spite of the fact that Government considers all land without individual or formal legal title to be the property of the state no tribal land has yet been 
expropriated without priority going to the indigenous population - the case of the Rufa'a el Hoi and mechanized farming has already been cited, the New Halfa scheme was nominally developed to resettle the Nubians but the Shukriya and associated tribes occupy almost half of its area, and most tenancies in the Gash and Baraka schemes have been allotted to tenants from the Beja tribes, with some distinction of the rich among the tribespeople;

. development of water sources by astute representation on boards controlling district, regional and national development plans;

. provision of services and infrastructure by obtaining budgetary allocations as in (ii);

. improved livestock, especially veterinary, services and especially for the major epidemics such as rinderpest;

. continued representation on political and decision making bodies at all levels and perhaps especially on the Livestock and Meat Marketing Corporation;

. reinstatement recently (1991) of native administration with tribal chiefs given full administrative, judicial and taxation powers over their domains.

. and continuing the tradition of convening tribal conferences.

Table 5 - Distribution of families (average of 7 persons) by wealth ranking in the main cattle-owning areas

\begin{tabular}{|c|c|c|c|}
\hline \multirow{2}{*}{$\begin{array}{l}\text { Area } \\
\text { and } \\
\text { Livestock species }\end{array}$} & \multicolumn{3}{|c|}{ Wealth rank (Number of animals) } \\
\hline & Rich & Average & Poor \\
\hline \multicolumn{4}{|l|}{ Southern Darfur: } \\
\hline Cattle & 210 & 77 & 28 \\
\hline Sheep & 63 & 21 & 7 \\
\hline Goats & 9 & 3 & 2 \\
\hline \multicolumn{4}{|l|}{ Southern Kordofan: } \\
\hline Cattle & 154 & 56 & 21 \\
\hline Sheep & 63 & 21 & 7 \\
\hline Goats & 4 & 3 & 2 \\
\hline \multicolumn{4}{|l|}{ White Nile: } \\
\hline Cattle & 210 & 77 & 28 \\
\hline Sheep & 210 & 70 & 28 \\
\hline Goats & 9 & 3 & 2 \\
\hline \multicolumn{4}{|l|}{ Blue Nile: } \\
\hline Cattle & 196 & 70 & 28 \\
\hline Sheep & 189 & 63 & 21 \\
\hline Goats & 125 & 40 & 3 \\
\hline \multicolumn{4}{|l|}{ Kassala: } \\
\hline Cattle & 140 & 49 & 21 \\
\hline Sheep & 154 & 56 & 21 \\
\hline Goats & 125 & 40 & 3 \\
\hline
\end{tabular}

\section{The sub-tribe}

The sub-tribe operates in much the same manner as the tribe, with the various factions attempting to maintain their rights and privileges or to usurp those of others. As for the tribe, some cohesion has been lost and not least, here also, because individual interest is assuming dominance over that of the group. Sub-tribal groups are often in the anomalous situation of collaborating while competing. Collaborating to keep out people and interests not of the tribe and competing for influence and affluence within the tribe. The contributions of the sub-tribe to the organization of 
settlement of disputes arising from conflicts of interest;

organizing grazing movements and timing, by the use of scouts, and especially in the rains, by monitoring pasture condition and sources of water;

. protecting people and property at critical times by group action (e.g. in the case of cattle theft, but this traditional response and the resort to arms is looked upon with more and more disfavour by higher authorities);

. helping to maintain services in the group area;

representation at the local level.

\section{The household}

The household is usually and extented rather than a nuclear family unit. The reasons for this are the mixed species nature of the livestock holdings which often require separate herding and management and the diversity of other production tasks which demand varied skills and strengths. The household thus usually comprises a man and his wife and their married sons plus unmarried sons and daughters. The household unit comprises sub-units, each with its own house or tent, usually placed close to each other and perhaps around the periphery of the bedding ground of the animals.

Sons who succeed in establishing their own herds and their own households usually camp and move in proximity to their father. Other family units, also of close relatives, are also found grouped at some distance the one from the other.

The household roles differ to a considerable extent from those of the higher units. They include:

. producing and rearing children to maintain continuity and to achieve economic and social goals

providing and organizing labour for herding, cultivating and other activities;

taking of decisions with respect to herd policy, (management, sales and hospitality) and sale of agricultural products and purchase of consumption needs;

generating income from wage labour or from commerce to supplement family cash resources and for investment in additional livestock

purchasing, preparing and cooking (and often collectively eating) household food;

ensuring that herd size and productivity is adequate to start new households when married sons have families of their own;

fulfill cultural and social obligations to relatives, neighbours, the tribe and passers-by in order to maintain and enhance the household status in the wider community.

\section{External relations}

The tribe, from being an autonomous and self contained cultural unit, has been forced in to more and more involvement with its external environment. In particular it has to deal with government at all levels. 
Major changes in governance were instigated at independence. It is from this time that a certain degree of dissatisfaction with the native administration started, and has continued, to accrue. Much stems from the so-called democratization process and the new roles the tribal elite annexed to themselves in government and in public life.

The functions of the former Native Administrations were devolved to Local Government Councils between 1969 and 1972. In 1973 a new Local Government Act was placed on the statutes, supposedly founded on the philosophies of self-rule and self-reliance. Old provinces were confirmed and new ones created under the act. Within each province were area, rural and village councils. The propagators and proponents of the new Act, in addition to self-rule and self-reliance, assigned high priorities within its context:

- breaking the forces of tribalism which were viewed as obstacle in the process of development;

- taking decision-making to the grass-roots level to encourage active involvement and participation in development through mobilization of the resources of the rural masses.

In 1983 a new enactment introduced the Regional Government Act to the Statute Book. This added yet another and superior tier to that already existing by creating seven regions. In 1986 a conference on regional and local government convened in Khartoum and made new recommendations for the political and administrative organization of the Sudan. The recommendations were submitted to the Council of Ministers for endorsement.

These multiple changes in government and administration at all levels, and especially the abolition of the Native Administration, have had multiple effects on the pastoral populations. It is considered that an "administrative vacuum" exists, the principal shortcomings of which are:

1. inability to control the increase in the incidence of tribal conflict (which in the past was usually quickly resolved by tribal elders) without too much bloodshed or loss of consequent on declines in water and grazing resources, encroachment on other tribes'territories, planned and unplanned expansion of irrigated and mechanized agriculture;

2. an "arms race" and increase in the ownership of illegally acquired modern weapons in order to be at least at parity with the other contestants in the conflicts cited in (1);

3. an increase in the incidence of organized and large scale armed robbery, especially in Darfur Region (normally blamed on Bedayat from Chad and as narrated by a Zhagawa chief (1989) "in the past it was my duty as a tribal chief to raise my men once a robber is traced into my territory, because very soon he would become a danger to all neighbouring groups ... also I would be questioned by the District Commissioner at Kutum, as to why I did not act accordingly ... presently it is not my responsibility to do so, and if a group comes after a robber the most I can do is offer them hospitality";

4. a sharp reduction in the amount of animal tax collected since the now-responsible Local Government Officers are not native to the area, do not live with the people, do not understand the tribesmen's psychology and are present in the camps or markets only to collect tax - the net tax yield is even further reduced when compared to the old system of making the tribe responsible for collection as the collectors are paid wages and incentives, drivers and others have to be employed and vehicles have to be provisioned and maintained.

The above adverse effects have instigated the present government to reistate the native administrative system, and as of mid. 1991, the system cameback with full, judicial, administrative and tax collection powers.

\section{Acquisition of animals}

The most common method of acquiring livestock is, of course, through birth and natural increase. Herds can also be built up by purchase of animals. Money for purchase comes from savings, from sale of other animals, from wage labour or from remittances from relatives involved in commerce. Pastoral societies have, however, several other mechanisms for ensuring that all their members share in and benefit from the common wealth. Many of these mechanisms are designed to ensure that, within the context of sharing, the wealth stays in the family or at least in the tribe. Some of the methods that have developed for acquiring and disposing of stock are common to many groups while others are particular to only one: 
. the Hadendowa present a newly born child with a female animal of each species of stock the family owns;

the Kababish give a female camel to a new born child;

. the Hawazma new born son is given a cow by his father's brother on anticipation of a future marriage to the latter's daughter;

the first time a Kababish child has a haircut he receives a female animal from his father;

. in all tribes a man who marries receives animals from his father's brothers and from his agegroup agnates;

. among the Nilotes the dowry is paid in cattle provided by both paternal and maternal kin and the receiving family divide it in a similar fashion;

. in all tribes a proportion of household heads distribute animals to their sons over the course of the lifetime;

. among the Hadendowa the newly married spend the first year with the family of the bride to allow their own herd to increase;

. some Hadendowa pool resources to buy a female camel which becomes the property of one of the group but the offspring are distributed in turn to the original contributors.

\section{Animal management}

There is little or no capital investment by the owners in animal management. Herding is done in the age-old way, one or more herdsmen being constantly with the stock when they are at pasture. All household members, from the very young to the very old, women as well as men, have some responsibility at some point in the production process. Herds are, strictly speaking, often larger than what is strictly required to assure subsistence because there is always risk of loss through epidemic disease, starvation as a result of drought and loss to predators (human thieves as well as animal killers). Animals are also the principal investment vehicle of pastoralists, a means of capital accumulation, a store of wealth and, possibly, a source of pride and prestige.

In recent years, and especially since the 1984 drought, there has been a tendency for concentration of livestock in fewer units. It is the age-old story as the rich (and probably financially capable and economically astute) have got richer and the poor have got poorer. For the poor, as for the rich, the costs of production have shown a steady and in many cases an obviously unmeetable rise. Water may now have to be paid for, herders want wages and not a portion of production (although they probably continue to appropriate or misappropriate that also), supplementary feed and minerals have to be bought, and drugs (once provided free) are expensive. Commercial attitudes are also developing which by their nature require concentration of animal wealth in fewer hands. The move to commercial production is exemplified by the shift in age, from older to younger, of the stock that are trekked from the production areas through local marketing to the major urban and export channels in the capital.

\section{Organization of labour}

In the past all labour was found in the family. Men were primarily responsible for herding and care of the livestock and women largely looked after the domestic needs of the household but also had some clearly defined livestock tasks. As families have become involved in agriculture it is again the men who do most of the work but women are important at sowing and harvest times.

In general terms the old order still prevails. There has, however, been a shift to employing labour 
from outside the household and, conversely, for household members to seek paid work outside the family business of herding and farming.

The household head is the senior manager: he supervises the overall requirements and allots tasks to individuals of his family. A "murah" of 300 sheep requires two men to herd it as does one of 100 head of camels. Smaller herds, of any species, may be combined with those of other families and herded communally on a labour rotation basis. A few cows, sick animals and young animals born out of season are herded near the camp or settlement by the women of the household or by young boys.

The tasks associated with daily management of the herds and flocks include supervision of grazing, protection of the stock and the provision of water. Ensuring that animals have adequate water is a major and often time-consuming and laborious task and largely explains the need for two herders for relatively small groups of animals. Even so, more labour may be required to provide water, especially if the source is a deep well or has low output. The dry season is particularly demanding of labour as grazing may be distant from water sources and these latter produce little water.

At the camp the women and girls are responsible for many tasks. They are helped by boys until these are eight years old, when they are given herding tasks. Female activities are diverse, including preparing and cooking food, providing domestic water, gathering fuel, collecting wild fruits and herbs, mending tents, curing skins and working leather, spinning and weaving, looking after the poultry and sick animals, and processing the milk to butter or cheese.

In general there are no taboos in most tribes against women undertaking the milking of the animals. They do in fact often milk all species except camels, which are too big and strong for them. Women also help with shearing in those groups that take wool from sheep for neg-making.

Animal wealth should increase with family size so that sons are fully employed and are also fully provided for. If herders have to be hired they have traditionally been paid largely in kind: a "hog" or 2-year old camel for herding camels for a year and six or seven "tini", or yearling sheep of mixed sexes, for looking after sheep. Times are changing, however, and according to a Rashaida "paid herders are becoming kings and we have to meet their terms".

The use of hired labour has greatly increased during the 1980s. Principal reasons for this include a reduced family size and some educated members of the family moving to better paid jobs in the local centres, the national capital or even abroad. An ironic situation exists in some cases where sons of owners have gone to Säudi Arabia or the Gulf States to look after expensive racing camels or other high value stock. The increased need for seeking herders from outside the family has resulted in a classic demand-supply situation and labour has become expensive. Wages vary by tribe and by species herded (a camel herder expects twice as much as a shepherd) but hired labour imposes additional costs on the owner such as the provision of food and clothing and the use of a donkey or other riding or pack animal.

The labour problem is one that is mainly confined to traditional male tasks. Female family members have, as yet, not had the same opportunities in education and in travel as their menfolk and at least for the time being most are still at home.

\section{Risk-avoidance strategies}

The diversification of species and herds are traditional strategies that reduce and spread risk. The adoption of cultivation is another such which broadens the resource base even further. External wage labour is also to some extent another strategy.

Pastoralism has always been a high risk occupation. It is more so in modern times in unstable and unsteady and at all times weak economies which are also open to external competition. The traditional skills of pastoralists in making the best use of grazing resources, of water supplies, of controlling disease in their animals, and of obtaining market information are now needed more, and to a higher degree, than ever before. 
Drought has been a menace since time immemorial. To cite just a few in recent times the Shukriya say they lost $20 \%, 30 \%$ and $60 \%$ of their camels, sheep and cattle in 1947-1948. The Zhagawa and many other western tribes suffered heavy losses in 1974-1975. Drought and famine, said by many to be man-induced through population increase and the explosion in livestock numbers with no provision for supplying more feed, are now apparently endemic, occur more and more often and are brought successively to the attention of the world via the media.

Traditional strategies to combat risk also include manipulating herd structure so that the proportion of breeding females is high. Accumulation of large herds (which has often been, and to some extent still is, considered as a pastoral ploy to gain prestige) of which at least some will survive in the event of drought or disease is another. Nomadism and transhumance are also ecological adaptations to the rigours of a stern environment and both assume more importance at times of more than unusual difficulty.

Modern strategies include reinforcement of traditional ones and the adoption of new methods. Supplementary feeding over longer periods and in greater quantities than hitherto is one such new strategy. Money to buy feed may be realized by selling some animals which is itself a new strategy. Liquidation of assets in the form of selling all one's animals is literally the last resort: the poor suffer first and most severely and the rich benefit by being able to augment their own resources at low cost.

\section{Conclusions}

Pastoralism has never been a static profession. The patterns and speed of change, however, are probably faster now than at any time in history.

The normal disparities in wealth among tribes and members of tribes have widened considerably. There are now very rich and very poor. Livestock ownership and other forms of wealth are concentrated in the hands of the former and many of the latter have had to abandon their pastoral way of life altogether. For the rich also it may be that pastoralism is now only a part of a more diversified business which itself is a modern form of risk avoidance.

Components of such a diversified household economy could include, in addition to livestock herding and cultivation, trading locally and internationally in livestock, transport of goods and people, and ownership of a shop. A sample of nomads, when asked what their perceptions of a comfortable life might be, indicated that a relatively well-to-do Shukriya might have a profile that included:

owner ship of 80 camels and 300 sheep;

a shop in a main town such as New Halfa or Gedaref;

ownership of a mechanized farm with a tractor that could also be hired out;

a lorry also for rent;

a "hawasha" tenancy on the New Halfa scheme.

Among the Rashaida the aspirations of the rich would be similar to those found in the Shukriya but more camels would be needed as well as a stake in the business of exporting camels to Egypt. By contrast the impoverished Rashaida, although perhaps no longer true pastoralists, would have more traditional values and would seek:

. provision, organization and improvement of pastures;

development of water supplies for people and animals;

better veterinary services for stock and improved human medical and education facilities;

means to ensure an adequate grain supply; 


\section{PASTORAL PRODUCTION AND ECONOMY}

\section{(CONTINUED)}

. "productive" sons to contribute to family welfare, since "vitality is not measured in numbers but in concern for the family".

Modern developments have resulted in a general weakening of group cohesion and decisionmaking. This has resulted in part at least from the decline in the value ascribed to reciprocal rights and duties and a corresponding rise in the value of personal and individual gain. These changes have themselves resulted in part not only from the loss of grazing and water resources but also from the loss of the control of these resources.

There is now more cohesion at the household level than at the tribal and sub-tribal levels but even this is continuing to decline. This is not to say that some traditional customs have not survived. The rich and powerful can still smooth the rough passage of life for the poor and needy by, for example, helping to provide education, interceding with the administration, and providing some comfort and succour during drought and famine. While these practices are still actively sought by the poor, who consider them to be the dues payable by blood relations the newly urbanized rich look upon them as more and more of a burden. Some old practices have disappeared or are rapidly disappearing. Assistance in building herds and stock loans are now the exception rather than the rule mainly, it would seem, because of the higher economic value of stock and the lack of need by the wealth for mutual and reciprocal services.

Pastoralism is evolving rapidly from a subsistence oriented, hunter-gatherer production system in which group welfare was seen as an important component of the whole to a system that is more commercially directed and in which self interest is assuming more importance. Livestock production per se might benefit as a result but the social and economic repercussions for a majority of former producers will remain.

\section{BIBLIOGRAPHY}

Adams M. - The Baggara problem: attempts at modern change in Southern Dhofar and Southern Kordofan.

Development and Change, 1982, 13 (2) : 259-289.

Ahmed A.G.M. - The Rufa'a al Hoi economy. In: Some aspects of pastoral nomadism in the Sudan.

Khartoum, Economic and Social Research Council, 1976.

Asad T. - The Kababish arabs: power, authority and consent in a nomadic tribe. London, C. Hurst and Co, 1970.

Barth F. - Economic spheres in Darfur. In: FIRTH R., ed. - Themes in economic development. London, Tavistock Publications. 1967. P. 149-77. (ASA Monograph n_6).

Barth F. - Human resources: social and cultural features of the Jebel Marra project area. Department of social anthropology, 1974. (occasional paper $\mathbf{n} \_1$ ).

Cunnison I. - Baggara arabs: power and the lineage in a Sudanese nomad tribe. Oxford, Clarendon Press, 1966.

Dafalla H. - The Nubian exodus. London, C. Hurst and Co, 1975.

Davies H.R.J. - Population change in the Sudan since independence. Geography, 1988, $\underline{63}:$ 249-255.

El Hassan M.O. - Lower order planning units for rural development in the Sudan. Sudan research unit, Faculty of arts, University of Khartoum Press, 1971. (African studies Seminar paper n_11).

El Sammani M.O., Abdalla B., EI Tayeb G., Suliman M.M. - Nomads of the semi-desert belt of northern Kordofan and Darfur Regions, Vol. 1, Economic and social research council of the national council for research. 1984, report $n .15$. 
Government Of Eastern Region Sudan - Population of the eastern region based on 1983 national census. Department of Statistics. 1984. (in Arabic).

HAALAND G. - Pastoral systems of production, the socio-cultural context and some of its ecological implications. In: O'KEEFE P. and WISNER B., ed. - Land use and development. London, International African Institute, 1977. P. 179-193. (Atrican Environment special report. n_5).

Haaland G., ed. - Problems of savannah development: the Sudan case. , University of Bergen. Department of Social Anthropology Bergen, Studia University Bookstore, 1980. (Department of Social Anthropology occasional paper n_19).

Hewison J.W. - The role of animals in the life of the Sudan, Land use department files. 1958. (Unpublished Office file Report).

Hill L.G. - Hababin village economy.

Sudan Notes Rec., 1968, $49: 58-70$.

Holy L. - Neighbours and kinsmen: a study of the Berti people of Darfur. London, Hurst, 1974.

Khalifa A. H., Simpson M.C. - Perverse supply in nomadic societies. Oxford Agrarian Studies, $1972,1: 46-56$.

Ministry For Social Affairs, Population Census Office - First population census of Sudan 19551956, Notes on Omodia map. Salsburg, Austria., KIESEL R., 1958.

Mac Michael H.A. - The tribes of northern and central Kordofan. Cambridge, Cambridge University Press, 1912. $259 \mathrm{p}$.

Morton J., Fre Z. - Red Sea Province and the Beja. London, Oxfam, 1986.

Reid J.A. - Some notes on the tribes of the White Nile Province.

Sudan Notes Rec., 1930, $13:$ 149-208

Salih H.M. - The Hadendowa: pastoralism and problems of sedentarization. Ph. D. Thesis, University of Hull, 1976. (Unpublished)

Seligman C.G., Seligman Brenda Z. - The kababish, a Sudan Arab tribe.

Harvard African Studies (Varia Africana), 1918, 2 : 105-184.

SORBO G.M. - Nomads in the scheme. A study of irrigation, agriculture and pastoralism in eastern Sudan. University of Bergen, 1974

Sudan Government Population census in Wadi Halfa rural area and town. Khartoum , Department of Statistics, 1974

Tully D. - Culture and context in Sudan. New York, State University of New York Press, 1988.

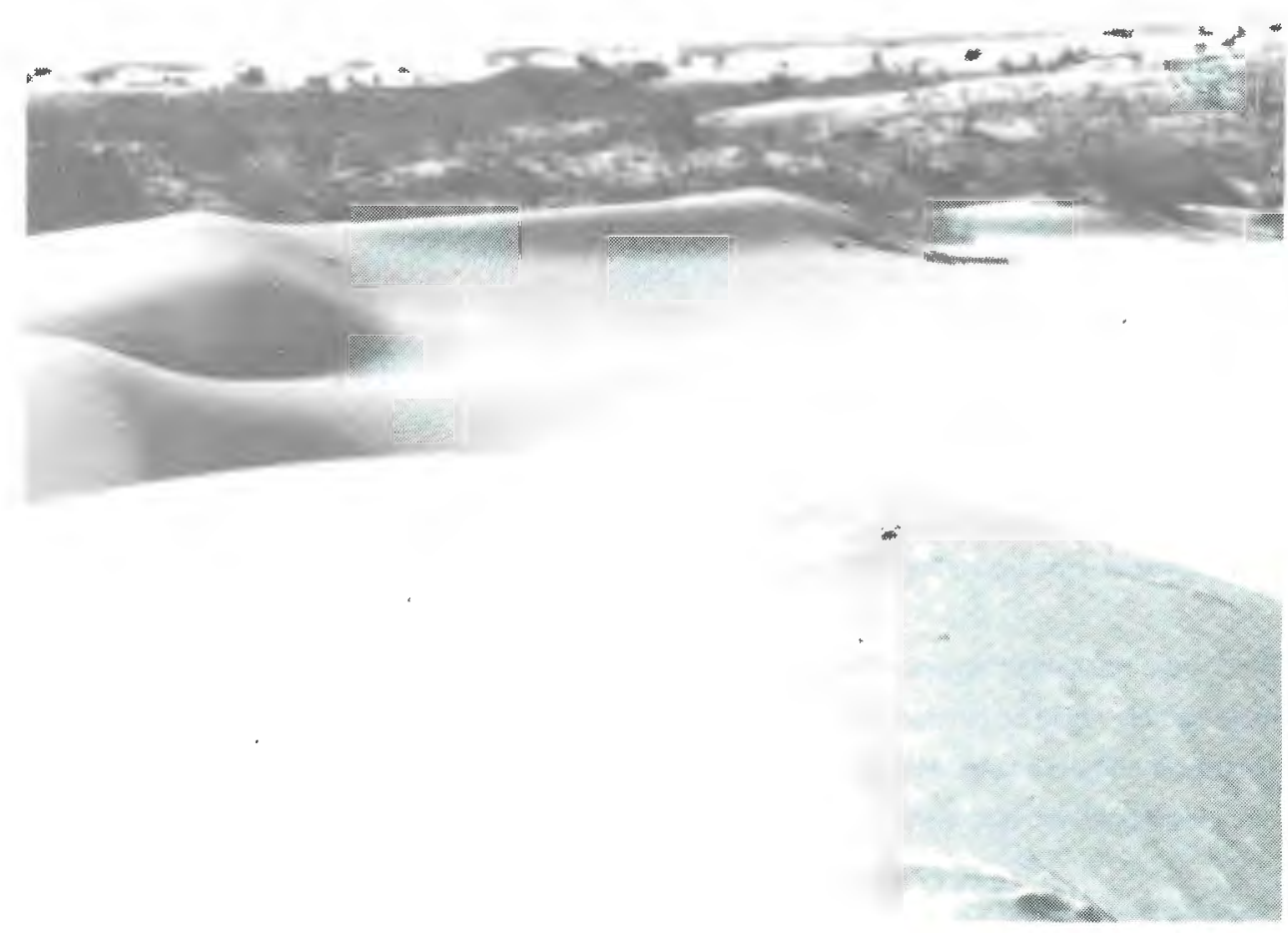


Livestock movements. El Sammani M.O., De Zborowski Isolde. 1993. In : Livestock production and sahelian rangelands potential: Republic of Sudan = Élevage et potentialités pastorales sahéliennes : République du Soudan. Darag A., Lamarque Georges. CIRAD-IEMVT - FRA. Wageningen : CTACIRAD-IEMVT, 27-28. ISBN 2-87614-088-8

\section{LIVESTOCK MOVEMENTS}

\section{M.O.EL SAMMANI}

Both camel and cattle owning groups have alternating patterns of dry and wet season grazing within the vast pastoral zone that extends from $10 \mathrm{~N}$ to $18^{\circ} \mathrm{N}$

In the wet season almost all the nomadic tribes remain with their herds in their tribal areas of "dar". During the dry season they move towards the south, the speed of this movement being governed by the rate at which the northern areas dry out. In the recent past, as drought has become a common occurrence, there has been a tendency to settlement in the south and towards the assumption of a transhumant way of life.

Livestock are moved along old-established routes and are herded in a traditional manner which involves little or no capital cost. Impediments to these age-old movements have become more common in recent years as the infrastructure related to large scale mechanized and rainfed agricultural schemes has been developed. Changes in traditional routes resulting from these causes increase risk through animals having to travel longer distances or because new routes traverse areas occupied by hostile tribes. In years of good rainfall opportunistic short distance movements are more common.

In the wet season some major factors affecting decisions on movement are:

traditional sub-tribal allegiances and rights to land;

accessibility to arable land for those sections which cultivate;

the common grazing rights of groups not of the same sub-tribe, campments being founded on "awlad rajil" or extended family lines;

. the necessity of leaving a part of the household in the "dar" area to deal with cultivation and to look after some sedentary cattle and the goats

the differing requirements for grazing of each animal species in the herd, with decisions on this aspect being made directly by the head of the household;

the need to avoid, especially for the Baqqara groups, areas of waterlogged soils and those where biting flies are present;

the need to avoid extensively cultivated areas and to use corridors through mechanized farming areas.

In the dry season a different set of factors needs to be taken into account, including

the need to stay near the areas of cultivation so that male household members can help with harvesting (although towards the end of harvest some animals with some men will move away);

the necessity of using areas of established rights;

the availability of water;

. kinship ties, especially with settlers on the large irrigated schemes (New Halfa, Gash, Rahad, Baraka), which facilitate early access to cotton stubbles;

being in a position close to the boundaries of dryland mechanizedrschemes for early access to sorghum stubbles. 
Wet season grazing used by all tribes lies wholly or partially within the "dar", which is the traditional homeland. Grazing in the dry season is usually outside the "dar". With few exceptions the "dar" area lies to the north or north-east of the dry season area, that is, in areas where rainfall is normally higher.

Within each "dar", grazing is organized on a sub-tribal basis, each sub-tribe or group of sub-tribes having rights over particular domains. Boundaries were more rigidly adhered to in the past when human and livestock pressures were less and when physical security could have posed problems if grazing was practised outside the traditional areas.

Outside the "dar" areas grazing rights are regulated by convention between the involved groups and by gradual acquisition of usufruct. Conflicts arising from these practices are usually resolved by intertribal meetings, held every two years or more frequently if there is need. Consequent on conventional agreements several major areas of the country are open to common grazing or at least to a large number of tribes. These areas include:

. the Butana plain, open to all tribes in Eastern. Central, Northern and Khartoum Regions during the rainy season;

. a buffer zone in the north-central parts of Kordofan and Dartur used by the Kababish, Kawahla, Hawawir and Zayadiya during the 'shogara' (early wet) and "darat" (early dry) seasons;

. the "gizu" north of the Meidob hills and to the Sudan-Libya-Chad border, which is available in some years at the end of the rains and well in to the winter dry season, for all Northern Kordofan and Northern Darfur pastoralists;

the Kajamir area of sandy soils along the White Nile from Kosti south to Renk and used during the wet season by the Blue and White Nile tribes (including Rufa'a el Hoi, Kenana, Kibeishab, Ahamda and Manza);

the riparian lands of the upper White Nile, the Bahr el Ghazal and the Bahr el Arab which are used in common by the Baqqara groups (Awlad Humeid, Hawazma, Messeriya, Rizeiqat, Habbaniya, Beni Halba, Fellata and Ta'aisha) of the north and the Nilotic tribes (Shilluk, Dinka and Nuer) of the south;

the swamps or 'toich' grazing of the Bahr el Jebel which are also used by the Nilotic tribes in the dry season.

Within the "dar" areas, ownership of the infrastructure of wells and of cultivable areas is vested in the sub-tribe. This, along with the pressures that kinship can bring to bear on market, administrative and other government services, are responsible for sub-tribal dominance in and gives to an area its special characteristics. Within the "dar" there are certain established principles:

. reserved grazing is not grazed out of the season of its reserved use;

trees in wadi beds are not cut down as they provide valuable dry season browse for camels and goats;

. water from all wells, whether of the deep bore type provided by government, owned by a kinship group, or owned individually, is freely available to all for household use;

water for livestock is available to non-native groups only after the needs of all animals of the owning sub-group are satisfied;

- livestock are watered on a rotational basis by group members, the frequency of visits being 
determined by the facilities and yield of the source (note that some large capacity water sources such as deep bores, "hafir" and high-yield open-shaft wells are not always welcomed by some owning groups (such as the Hadendowa) for fear that they will lead to incursions of external groups, and note also that some Kababish chiefs have appropriated priority to themselves at some government-provided facilities where non previous traditional rights existed :

. digging and ownership of water sources by external groups is not usually allowed, especially by the Hadendowa;

- "hafirs" that are individually or communally developed by the Shukriya in the Butana give the owners access to settlements and to grazing and cultivating rights (note also that "hafir" development along the Kassala to Port Sudan road during its construction have allowed the Rashaida to settle previously unusable tracts of land);

cultivable land is used first by the owning sub-tribe and allocations to other groups are made only when local needs have been met (an in the case of the Hadendowa such allocations are for one year only in order to limit acquisition of long term rights);

- traditional holds on acquired rights and prohibitions against their being acquired are strengthened by agnatic (cross-cousin) marriages of the offspring of full brothers.

In spite of established custom there is evidence of erosion of these traditional rights to "dar" areas. Appropriation of priority at government bores is one example and the digging of wells and settlement by sedentary people in nomadic areas is another. The reasons for this do not relate solely to pressure on the land but are also related to a decline in the political influence that the nomadic tribes have enjoyed since the time of the Mahdiya.

\section{Migratory patterns}

The movement of livestock to the south generally starts in November but is earlier during years of poor rainfall and later in wetter years. Conflicts often arise in dry years as pastoralists invade the farm areas of the sedentary cultivators before the harvest is complete. The return to the north, particularly by camel and sheep groups, is usually in June-July but an early start of the rains engenders an early return. Not all animals make the regular seasonal treks. If movement is merely local within a season then it is easier for all animals to move as a group.

Most camels make the trek to the south in the dry season but some are left in the "dar" to provide milk for the old and young family members who also remain behind. A similar strategy is adopted for sheep where these are owned by the same people as camels. The cattle owning groups tend to have more permanent settlements than the more nomadic camel owners and a larger proportion of the family over a wide range of ages is more or less sedentary. More cattle are therefore left behind in the village to supply its needs. Similar proportions of sheep are left behind as cattle, especially if these are used to provide milk or if a major Mustim feast is imminent. Most goats remain in the village and, in any case, largely fend for themselves. Donkeys are taken on transhumance or left at the camp according to the needs for transport of household water and market goods of each unit.

The pattern of movement is complex and sometimes opportunistic. Each tribe or group of tribes has its own movement pattern (Table 1). The relation ships between one tribe and the neighbours which surround have always involved complicated agreements to share resources and these may have become more labyrinthine in recent years, as for example in the case of the Shukriya (Figure1)

as a result of the proliferation of large scale agriculture. 
Table 1 - Some examples of tribal annual grazing patterns

\begin{tabular}{|c|c|c|c|c|}
\hline \multirow{2}{*}{$\begin{array}{l}\text { Tribe or } \\
\text { Group }\end{array}$} & \multicolumn{4}{|c|}{ Season } \\
\hline & Early wet & Wet & Early dry & Dry \\
\hline Shukriya & \multicolumn{2}{|c|}{$\begin{array}{c}\text { July-October } \\
\text { Butana Plain } \\
\text { 'Hafir' and natural ponds govern distribution }\end{array}$} & $\begin{array}{l}\text { November-February } \\
\text { New Halfa-Rahad } \\
\text { irrigated and mechanized } \\
\text { schemes }\end{array}$ & $\begin{array}{l}\text { March-June } \\
\text { Rahad-New Halfa } \\
\text { mainly cotton stubbles }\end{array}$ \\
\hline Rashaida & \multicolumn{3}{|c|}{$\begin{array}{l}\text { June-December } \\
\text { Kassala-Qoz Rajab and Gash Delta scheme }(\mathbf{a})\end{array}$} & $\begin{array}{l}\text { January-May } \\
\text { Atbara River-Siteit }\end{array}$ \\
\hline $\begin{array}{l}\text { Kababish, } \\
\text { Kawahla, } \\
\text { Hawawir (b) }\end{array}$ & $\begin{array}{c}\text { June } \\
\text { Central Kordofan (En } \\
\text { Nahud) } \\
\text { Eastern Darfur (Umm } \\
\text { Keddada) }\end{array}$ & $\begin{array}{l}\text { July-October } \\
\text { 'dar' Kababish (Soderi) } \\
\text { Northen Darfur (Mellit } \\
\text { and Kutum(c) }\end{array}$ & $\begin{array}{l}\text { November-December } \\
\text { 'dar' Kababish (Soderi) } \\
\text { Central Kordotan (En } \\
\text { Nahud and Bara) }\end{array}$ & $\begin{array}{l}\text { May-July } \\
\text { Central and Southern } \\
\text { Kordofan (En Nahud, } \\
\text { Bara, Umm Ruwaba, } \\
\text { Rashad, Dilling, Rugel } \\
\text { El-Fula and Kadugli) }\end{array}$ \\
\hline Meidob & $\begin{array}{c}\text { June } \\
\text { Eastern and Central } \\
\text { Darfur (Mellit and El } \\
\text { Fasher) }\end{array}$ & $\begin{array}{c}\text { July-October } \\
\text { Northern and Eastern } \\
\text { Darfur (Mellit, Kutum, } \\
\text { Umm Bayoda, Meidob } \\
\text { Hills }\end{array}$ & $\begin{array}{c}\text { November-December } \\
\text { Northern and Central } \\
\text { Darfur (Mellit and El } \\
\text { Fasher) }\end{array}$ & $\begin{array}{c}\text { March-June } \\
\text { Eastern and Southern } \\
\text { Darfur (Umm Keddada, El } \\
\text { Fasher, Ed Dain, Buram. } \\
\text { Idd el Ghanam and } \\
\text { Zalingei)(d) }\end{array}$ \\
\hline Zayadia & $\begin{array}{c}\text { June } \\
\text { Eastern and Central } \\
\text { Darfur (Umm Keddada } \\
\text { and } \\
\text { El Fasher) }\end{array}$ & $\begin{array}{l}\text { July-October } \\
\text { Northern Darfur (Mellit } \\
\text { and Kutum and } \\
\text { Northwards) }\end{array}$ & $\begin{array}{c}\text { November-February } \\
\text { Northern and Central } \\
\text { Darfur (Mellit and El } \\
\text { Fasher) }\end{array}$ & $\begin{array}{c}\text { March-June } \\
\text { Eastern and Southern } \\
\text { Darfur (Umm Keddada, EI } \\
\text { Fasher, Ed Dain. Buram, } \\
\text { Idd el Ghanam and } \\
\text { Zalingei) }(e)\end{array}$ \\
\hline Zaghawa & $\begin{array}{c}\text { June } \\
\text { Eastern and Central } \\
\text { Darfur (Umm Keddada } \\
\text { and } \\
\text { El Fasher) }\end{array}$ & $\begin{array}{l}\text { July-October } \\
\text { Northern Darfur (Meilit } \\
\text { and Kutum and } \\
\text { Northwards) }\end{array}$ & $\begin{array}{c}\text { November-February } \\
\text { Northern and Central } \\
\text { Darfur (Mellit and EI } \\
\text { Fasher) }\end{array}$ & $\begin{array}{c}\text { March-June } \\
\text { Eastern and Southern } \\
\text { Darfur (Umm Keddada, El } \\
\text { Fasher, Ed Dain, Buram, } \\
\text { Idd el Ghanam and } \\
\text { Zalingei })^{(f)}\end{array}$ \\
\hline Hadendowa & \multicolumn{4}{|c|}{$\begin{array}{l}\text { Rains differ, falling in two periods in Summer (July-October) and Winter (March-July) } \\
\text { Summer migration to 'oleib' in Red Sea Hills, to Eritrea and Gash and Baraka Deltas } \\
\text { Winter migration to 'gunub' on coastal plain } \\
\text { Supplementary migrations all year along tine of rail between Haya and Dordeib }\end{array}$} \\
\hline $\begin{array}{r}\text { Notes: (a) } \\
\\
\text { (b) } \\
\text { (c) } \\
\text { (d) } \\
\text { (e) }\end{array}$ & \multicolumn{4}{|c|}{$\begin{array}{l}\text { This current pattern differs from earlier one when rainy season was spent between Khasm el Girba and Gash schemes } \\
\text { and area between Atbara River and Butana, and dry season in Atbara and Siteit Rivers and into Eritrea } \\
\text { Seasonal movements are known by these tribes and by Shukriya as 'shogara', 'nishooq', 'dar'at' and 'damar' } \\
\text { 'gizu' grazing far to the north is used in years it is present } \\
\text { Northern Darfur tribes occupy parts of Southern Darfur in severe droughts } \\
\text { Travel less far south in years of better rainfall }\end{array}$} \\
\hline
\end{tabular}

\section{Fig 1 - Shukriya grazing area and regional} relations with production schemes

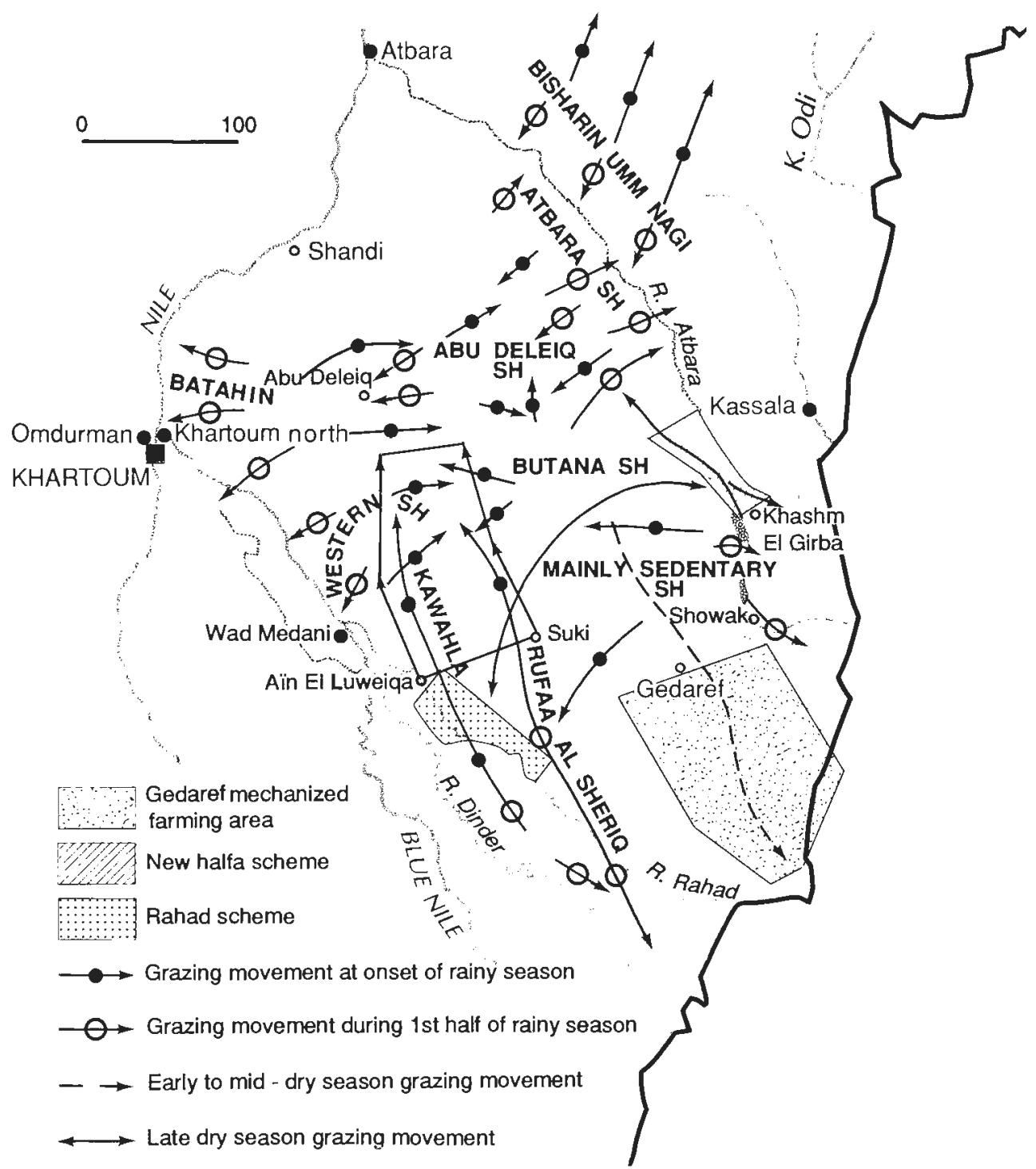




\section{Species movements}

\section{Camels}

Camels cover more diștance in the regular seasonal migrations than any other species and is always found farther north in the dry season. Camels go less far south in the wet season although they now graze much farther south of their traditional areas than they did previously.

\section{Cattle}

Owners who depend largely on livestock for their subsistence move over greater distances than those who are largely agropastoral and derive much of their livelihood from crop production.

Major wet season movements are undertaken from south to north across the whole central pastoral belt from Southern Darfur situated in the west, Southern Kordofan, White Nile. Blue Nile and to Kassala Provinces in the east. Such movements are always, however, within the confines of the homeland. Animals and herders return to the cropped areas around, for example, South Kordotan, Dạli and Gèdar'ef in the dry season. Some traditional tribal areas in the east extend into Ethiopia.

Shorter distances are travelled by cattle of the agropastoralists in the southern parts of Kassala and Blue and White Nile Provinces and those of the Nuba mountains. The Beja and Butana tribes that own cattle move around the Atbara river area and the Blue and White Nile tribes move to the "dahara"lands away from the river. Reverse movements take place as the rains finish, back to the cropped areas and the permanent water sources.

\section{Sheep}

Pastoralists mainly trek their sheep with their camels or cattle. The Beja of the Red Sea hills move between the upland pastures, the coastal plain and the flood plains of the Gash and Baraka deltas. Some travel as far as the Atbara river to the New Halfa irrigated scheme and others to the mechanized sorghum schernes in the Gedaref area. In Darfur and Kordofan wet season grazing is to the north of each "dar" while dry season grazing may be outside the traditional homeland, far to the south.

\section{Dry season concentrations}

\section{The Nuba Mountains}

Some 315,000 herders are estimated to move in to the Nuba mountains on their south in the dry season. They bring with them a total of 2.53 million cattle and more than 950,000 sheep. They belong principally to the Southern Kordofan Arab tribes: the Messeriya Zuruq, the Messeriya Humr, Hawazma, Awlad Humeid, and many smaller groupings. The proportion of herders staying longer and longer, even year round, is increasing and leading to more and more conflicts with the native Nuba tribes.

\section{The Bahr el Arab}

Even more herders spend the dry season around the Bahr el Arab than in the Nuba mountains. These are mainly of the Rizeiqat, Habbaniya, Taisha, Beni Hallba. Ma'aliya and Beni Hussein tribes. The estimated number of herders is 480,000 with almost 5 million cattle and 1.4 million sheep. As in the Nuba mountains there is a tendency to settle because of the relatively abundant feed and the permanent availability of water. Conflicts with the Dinka, when the Arab tribes cross the Bahr to the south, are not uncommon,

\section{The Gum beit}

The central zone of the Sudan, being the transition from the dry north to the humid south, is dominated by "Hashab" and the main production area for gum arabic, the vernacular name being used for the tree Acacia senegal from which the gum is harvested. The zone is also heavily populated and densely cultivated by sedentary farmers. Enormous numbers of livestock are found in this area in the dry season as nomadic herders move in to augment the already large numbers of local and permanent animals. More animals come from the north, mainly camels and sheep. As elsewhere when farmers and herders meet and compete for the same area of land, originally for different use but now often for the same use (whether that be for stock or crops) the numbers of conflicts are increasing rapidly. 


\section{Large scale agriculture}

The development of irrigated and mechanized rainfed agricultural schemes has provided a large quantity of crop by-products where previously there was little or even nothing for animals to eat. Water is also usually adequate in the case of irrigated agricultural schemes.

\section{Factors influencing migratory patterns}

Migration cycles and patterns evolved steadily over hundreds or possibly thousands of years. For long periods there was little other than minor change in the pattern and timing of movements. In the last half century, however, there has been a rapid evolution in the patterns of movement due to a variety of reasons.

\section{Agricultural development}

The first large scale agricultural development took place in the Gezira as early as the 1920s. More recently the establishment of the New Halfa scheme consequent on the flooding of Lake Nubia in 1960-1966, and the Rahad scheme in the mid 1970s, have exerted a profound influence on livestock movements over wide areas. In the central belt from Darfur to Kassala the mechanized rainfed schemes have also affected the timing and extent of movement.

The effects have been of two kinds. The agricultural schemes have taken over vast tracts of traditional grazing land and rendered them unavailable to livestock for a considerable part of the year. They have, however, also provided large amounts of dry season feed in the form of crop residues and by-products. In many instances it cannot be doubted that the quantity and quality of these new feed resources is superior to that which was there before.

This notwithstanding, there is reason for continued concern at the planned and unplanned expansion of large scale agriculture. As early as 1948 in the Butana a "Grazing Line" was established, north of which no cultivation was to be allowed. Over the years respect for this line has lapsed and many unplanned (and therefore illegal) schemes have developed. Many of the transgressors are themselves Shukriya or members of other pastoral tribes who have become rich in commerce and invest in agriculture for personal rather than for community gain.

\section{Range degradation}

Increases in human populations have led to concomitant increases in livestock numbers. Increases in livestock have resulted from the need for more animals to provide protein for people. The build up of the herds has largely been possible because of improvements in the ability of government services to combat animal disease, especially the major epidemics such as rinderpest.

More livestock, with few exceptions, have not been accompanied by similar increases in feed availability. Indeed much former rangeland (in addition to that taken by large scale development which, it is estimated, is reducing the range area by $2-4 \%$ per year) has been pre-empted to agricultural production by sedentary farmers who, becoming livestock owners themselves, reserve crop residues for their own use. The result is plain to see: vast areas are denuded of vegetation, with the more palatable species disappearing first, and subject to sheet and gully erosion.

In the pre-independence period and for some time afterwards local authorities were responsible for fire control and many hundreds of kilometres of fire lines were established. These were maintained and burnt early in the dry season to prevent the spread of wild fires. Lax administration and lack of finance have resulted in a discontinuation of this important practice. Further reduction of feed resources by uncontrolled fires raging over, often, many hundreds of square kilometres is the result.

The increase in sources of permanent water, often made available against the advice of range scientists but at the demand of livestock owners, has often done nothing to relieve the processes of degradation. In many cases it has served to exacerbate them by allowing areas that were formerly only available for seasonal use to be continuously occupied. Large numbers of stock. 
Man made disasters have been compounded by natural and unusually severe and prolonged drought over the last 20 years.

In most "dar" areas there is now insufficient grazing for the animals the tribe owns. The natural solution is to seek feed elsewhere, with all the problems this entails in conflict with individuals and with the traditional administrative system which has always to some extend controlled grazing times and nomadic movements. Attempts to provide solutions to these problems include enclosure (often by thorns cut from trees, thus further reducing feed resources) and the imposition of grazing or watering fees on animals that lack traditional rights of use. So far attempts to solve these problems by these means have met with little success and in some cases have led to additional problems.

Internecine struggles, sometimes amounting to full scale conflict and the intervention of the security forces, have resulted from "abbala" or camel owners moving south to occupy and to attempt to usurp the lands of the 'baqqara' or cattle people. These struggles are due in part to a gradual expansive drift southwards, as exemplified by the Kababish during the course of the 20th century (Figure 2), but much more to massive and rapid invasions during the last decade over a wide front.

Fig 2 - Kababish expansion of grazing land over - time

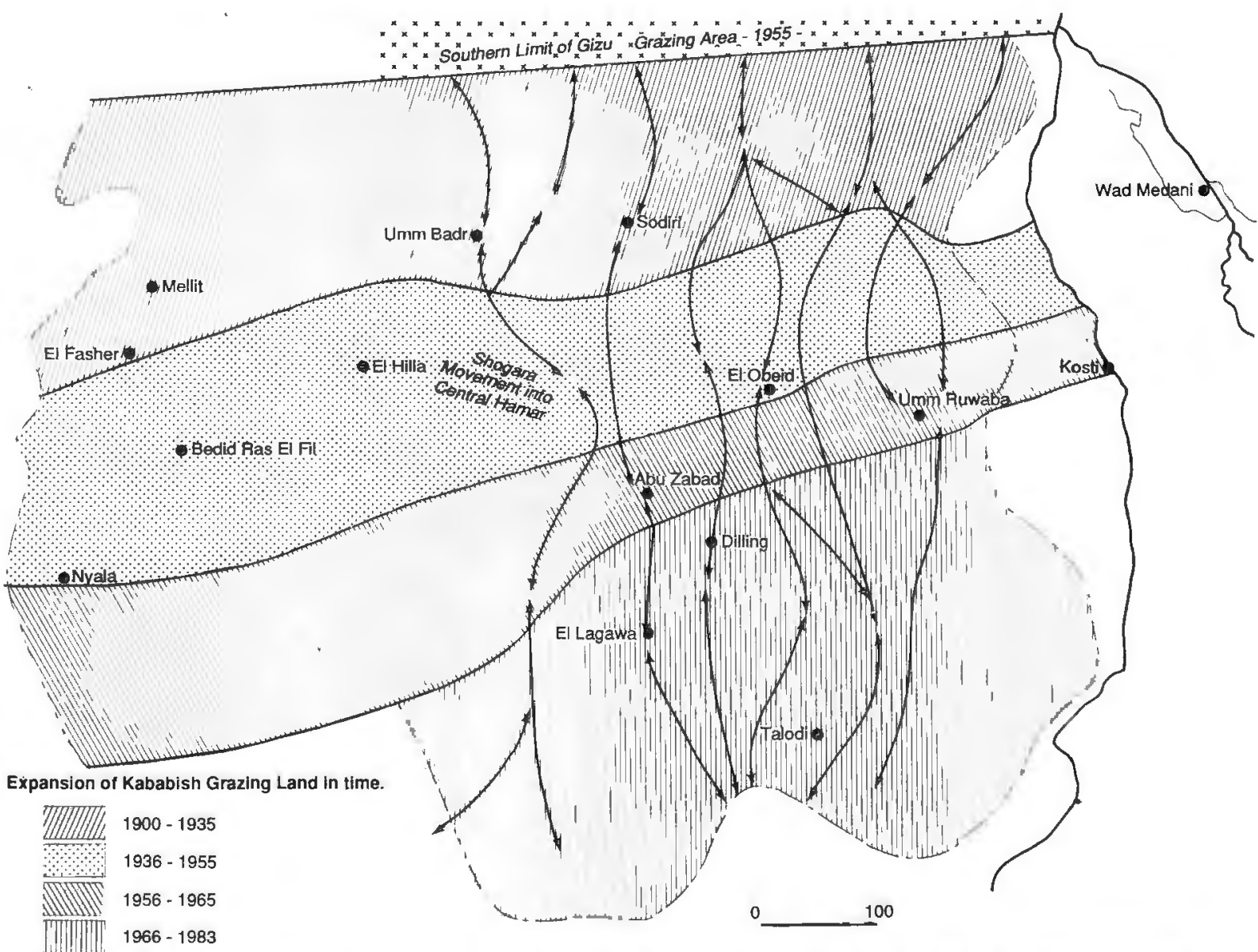

$\rightarrow \leftarrow$ Present migration Pattern

Source: M. O. El SAMMANI, B. ABDALLA, G. El TAYEB, M. M. SULIMAN, Aug. 1984

\section{Civil unrest in the south of the country}

The northern tribes, particularly the Baqqara, have always crossed the notional boundary between the "north" and the "south" of the Sudan in search of dry season grazing. In the last two decades this has happened more and more. Northerners have always faced hostility from southerners because of this practice but have been able to continue, largely as a result of political dominance. Full scale civil unrest in the south has resulted in the loss of much of this political support and a practice that was previously somewhat risky has now become positively dangerous.

\section{Sedanterization of pastoralists}

In addition to an expansion of cultivation by sedentary tribes, many pastoralists are themselves settling to cultivate their own crops. This transforms them to, at best, transhumants, willing only to move their stock over much shorter distances and for shorter periods than heretofore. The trend to settlement is due to a number of factors that may be associated with a modern lifestyle: 
provision of permanent water by local authorities;

initiation and adoption of farming practices, both rainfed and irrigated;

the search for improved quality of life, including access to human and animal health services and to education.

\section{BIBLIOGRAPHY}

Abu Sin M.E. - A survey and analysis of population mobility within Northern and Central Sudan, Ph. E. Thesis, University of London, Bedford College, 1975. (Unpublished).

Abu Sin M.E. - A change in strategy of animal herding among the nomads of the Butana - eastern Sudan. In: HEINRITZ G., ed.- Problems of agricultural development in the Sudan. Federal Republic of Germany. Edition Herodot, 1982.

Abu Sin M.E. - Livestock economy and attitude of tenants: Rahad and Khashin el Girba, a comparative study. Khartoum, Rahad Corporation, 1983.

Abu Sin M.E., El Sammani M.O., Mustafa M.M. - A socio-economic study and a strategy for development of the nomadic groups of the project area.

Blue Nile Integrated Agricultural Development, El Damazin. 1984

Ahmed A.G.M. - Planning and the neglect of pastoral nomads in the Sudan. In: HAALAND G., ed. - Problems of savannah development: the Sudan case. University of Bergen. Department of social anthropology, 1980. P. 39-54. (Occasional paper).

Ahmed A.M. - Project of community development, for settlement of nomads in the Sudan. SNPC, 1976.

Amin N.O. - Evaluation of the Gerih El Serha settlement scheme. M. SC. Thesis, University of Khartoum. Institute of environmental studies. 1984. (unpublished).

Asad T. - Seasonal movements of the Kababish Arabs of northern Kordofan.

Sudan Notes Rec., 1964, 45 : 48-58.

Awad M. - Sedentarisation of nomads in the Butana region of northern Sudan.

Bull. Soc. Géogr, Egypte, 1964, 37 : 5-33. Abstract in: Geographical Abstracts 68D, abs. 1118.

Behnke R.H. - Open range management and property rights in pastoral Africa: a case of spontaneous range enclosure in S. Darfur. Sudan, ODI, 1985.

Chalmers A.W. - Advantages and disadvantages of nomadims with particular reference to the Republic of the Sudan. In: A.J. Smith, ed. - Beef cattle production in developing countries. Proceedings of a Conference held in Edinburgh, 1-6 September 1974. Edinburgh, Centre for Tropical Veterinary Medicine. 1976. P. 388-397.

Davies H.R.J. - Nomadism in the Sudan.

Tijdschr. econ. Soc. Geogr., 1966, $\underline{57}$ : 193-202.

EI Tayeb O.Y. - The Shukriya of the Butana: pastoralism and problems of settlement and agriculture in New Halfa Scheme. M.A. Thesis. University of Khartoum, 1980. (Unpublished).

Fadalla A.H. - Settlement of the Rashaida tribe. Seminar on delivery of social and economic service to pastoralists. Sudan socialist union. (undated). (Unpublished paper in Arabic).

Government Of Kordofan Region - Survey of Fellata forest (El Obeid) of camps of environmentally affected refugees. Department of planning and economy, 1985. (in Arabic).

Haaland G. - Nomadization as an economic career among sedentaries in the Sudan savanna belt. In: CUNNISON J., JAMES W., ed. - Essays in Sudan ethnography. London, Hurst, 1972. P. 148-172.

Johnson D.L. - The nature of nomadism: a comparative study of pastoral migrations in Southwestern Asia and Northern Africa. Chicago, University of Chicago, 1969. vii 200 p. (Department of geography research paper $n \_188$ ).

Khalil S.S. - A study of environmental refugees in the Sudan: the case of drought affected migrants of North Kordofan to the peripheries of Omdurman. M. Sc. Thesis, University of Khartoum, Institute of environmental studies, 1985. 


\section{LIVESTOCK MOVEMENTS (CONTINUED)}

Khogali M.M. - Sedentarization of nomadic tribes in the North and Central Sudan. University of Khartoum Press, 1980.

Khogali M.M. - The changing nature of nomadism in the northern White Nile Region. In: DAVIES H.R.J., ed. - Rural development in White Nile Province, Sudan. Tokyo, United Nations University, 1986. P. 65-72.

Khogali M.M. - An assessment of Gereih al Sarha pilot project scheme for the settlement of the nomads and improvement of the livestock sector in the Sudan.

Geo J., 1987, $14:$ :53-62.

Musa Fathia Salih - The impact of settlement of nomadic people: experience from Kassala Province of eastern Sudan. M. Sc. Thesis. University of Khartoum, Institute of environmental studies, 1984.

National Council For Social Welfare - A study of settlement of nomads in eastern region. Khartoum, National Council for Social Welfare, 1980.

Salem - Murdock M. - Nubian farmers and Arab herders in irrigated agriculture in the Sudan: from domestic to commodity production. Ph. D. Thesis. Binghamton, State University of New York, 1984.

Sorbo G.M. - Tenants and nomads in eastern Sudan. A study of econopic adaptations in the New Halfa scheme. Uppsala, Scandinavian Institute of African Studies, 1985.

Wilson R.T. - Temporal changes in livestock numbers and patterns of transhumance in Southern Darfur, Sudan.

J. Developing reas. $1977,11: 493-508$. 


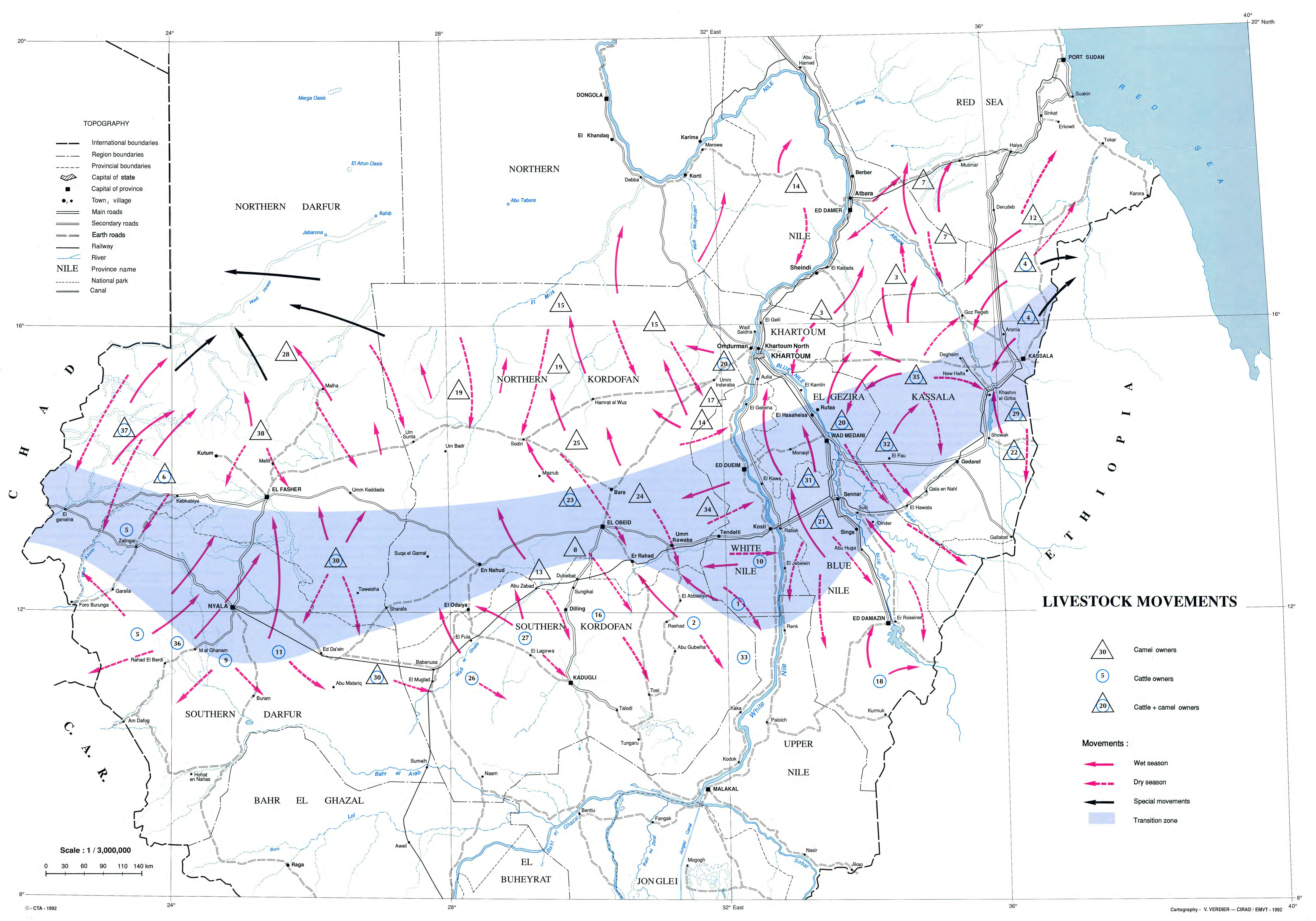




\section{LIVESTOCK RESOURCES}

\section{H.I. KHATAB}

Livestock resources. Khatab H.I., Verdier Véronique. 1993. In : Livestock production and sahelian rangelands potential: Republic of Sudan = Élevage et potentialités pastorales sahéliennes : République du Soudan. Darag A., Lamarque Georges. CIRAD-IEMVT - FRA. Wageningen : CTA-CIRAD-IEMVT, 29-31. ISBN 2-87614-088-8

Several attempts have been made to carry out "censuses" of livestock in the Sudan. The earliest one dates back to 1926 . Such estimates are often complemented by data from other sources including, but not exclusive to, those from vaccination campaigns, livestock taxes and the production of hides and skins. The most intensive efforts were made in 1975-1976 when a series of aerial surveys was undertaken : the apparently precise figures resulting from these, in view of the difficulties of counting nomadic livestock, must be treated with the usual reserve. Complications also arise in any census attempt as a result of the climatic variations characterized by a series of good years that are succeeded by drought. It is generally held, based on several sources, that there was a steady increase in animal numbers over the half century preceding 1980 (Figure 1) followed by a much slower rate of growth in the last $10-12$ years as a result of the persistent series of dry years and the consequent heavy losses.

What is also evident from Figure 1 is the uncertainty of the successive estimates for all species. Annual rates of increase for cattle, sheep, goats and camels in 1976 were estimated at $6.1,2.8$, 4.1 and $3.4 \%$ but the slopes of the lines in Figure 1 represent $4.0 \%$ for cattle, $3.8 \%$ for small ruminants and $3.8 \%$ for camels: these figures themselves would have result in the doubling of livestock numbers, depending on the species, each 17-20 years in the period 1926-1980. A further complication is that the figures for the period after 1976 refer only to samples from the north of the country. These are possibly not relevant to the whole, as it is likely that the effects of drought have been less marked in the south than in the north (see also the section on stocking rates).

\section{Fig 1 - Livestock population in the Sudan}

40

20

5

2.5

0.5

Livestock numbers

million head
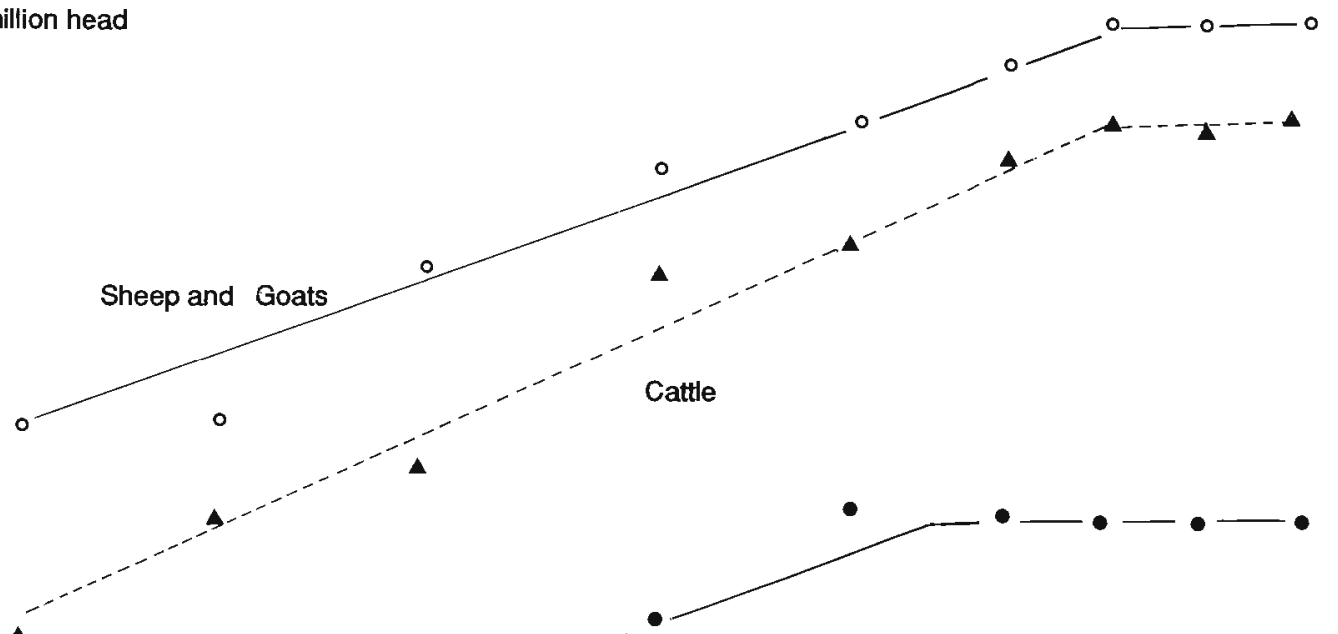

$\Delta$

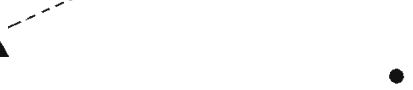

Camels

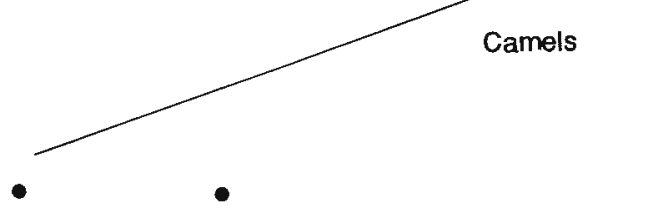

years

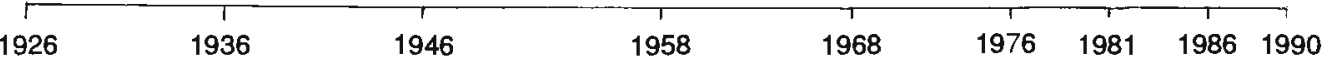

As a result, figures that purport to provide total numbers (Table 1 ) may be more useful as an indication of relative distribution, rather than as actual totals. With this in mind it can be seen that the grazing areas between the 12th and 18th parallels carry two-thirds of the small ruminants, almost all the camels and some $40 \%$ of the cattle of the country. This distribution is an adequate indication of the ability of the various species to survive and produce in these dry areas. Sheep are always slightly more numerous than goats, especially in proximity to the major towns where they find a ready market. More than $27 \%$ of all small ruminants are concentrated in the Central Province while cattle are concentrated in the higher potential areas or in the south of the country. 
Livestock owners do not usually specialize in one species: $80 \%$ of people owning sheep also own camels and $40 \%$ own cattle, while almost all of goats as well. Each domestic animal species is considered to have a particular role in the production strategy and each has advantages and disadvantages.

Table 1 - Numbers ('000) and regional distribution of livestock in the Sudan in 1989

\begin{tabular}{l|r|r|r|r}
\hline \multirow{2}{*}{ Region } & \multicolumn{4}{c}{ Species } \\
\cline { 2 - 5 } & \multicolumn{3}{|c|}{ Cattle Sheep } & Goat Camal \\
\hline Northern Province & 39 & 553 & 504 & 191 \\
Eastern Province & 3884 & 5545 & 3486 & 316 \\
Khartoum and Central Provinces & 1204 & 2864 & 2077 & 976 \\
Northern Kordofan & 1165 & 1634 & 1473 & 259 \\
Northern Darfur & 5399 & 2410 & 2238 & 165 \\
Southern Darfur + Southern Kordofan & 7140 & 3698 & 2474 & 38 \\
Southern Region & 19704 & 18806 & 13942 & 2705 \\
\hline
\end{tabular}

\section{Livestock breeds}

The majority of livestock breeds in the Sudan are found only within a tribal group. They usually derive from crosses between two or three major types, however, and often bear the name of the tribe. Modern cattle are generally descendants of the zebu which arrived in Africa from India, via the Arabian Peninsula or Egypt, and were crossed with the ancient longhorn stock. Over the centuries these "Sanga" types have been progressively absorbed, at least in Sudan, by further crossing with zebu animals. The last great influx. was relatively recent, following the great rinderpest pandemic at the end of the 19th century. In a similar manner, modern sheep and goats are mixtures of early Arab and Nilotic stock.

\section{Cattle}

The Northern Sudan Shorthorned Zebu have a long head, narrow face, flat forehead and convex profile. Naturally polled animals occur occasionally. Ears are large and usually pendulous. The hump varies somewhat in size, as it does in shape, but is usually cervico-thoracic in position with only slight variation: it is large and well-muscled in the male, smaller in the female. The dewlap, navel fold and sheath are usually medium to large. The chest is narrow and the ribs not well sprung; the back slopes steeply upward, the rump downward and the tail head is set low. The thighs are poorly muscled and the legs relatively long. The skin is loose and the coat short and of varied coloration.

Sudan cattle are late maturing and age at first calving in traditional herds is usually in excess of four years.

The majority of cattle are owned by nomadic or semi-nomadic Arab tribes and are kept primarily for milk: they are used by some tribes, however, as riding and pack animals. In general Sudanese cattle are well adapted to the prevailing conditions.

Sudanese cattle derive from four sources. The Baggara type is the closest to the true zebu. The Kenana and Butana have been crossed to some extent with the Hamitic longhorn, as already mentioned, but now show little evidence of the classic Sanga type. The Um Bororo cattle belong to the so-called Fellata tribes, who are still mainly limited to the west of the country and are of western origin, including Niger, Nigeria and Chad. Some original indigenous cattle are still found in the eastern hill areas and in the south of the country. 


\begin{tabular}{|c|c|c|}
\hline Species & Advaintages & Disotgontage \\
\hline Camels & $\begin{array}{l}\text { Robust and hardy } \\
\text { Large grazing radius of } 40-60 \mathrm{~km} \\
\text { Browsers } \\
\text { Can be watered at long intervals } \\
\text { especially on "gizu" when can go } \\
\text { up to } 4 \text { months without free water } \\
\text { Resistant to drought ( } 10 \% \text { losses } \\
\text { in } 1984 \text { ) } \\
\text { Easy to manage } \\
\text { Provides milk } \\
\text { Used for all types of transport } \\
\text { (including commercial hire) and as } \\
\text { a primary source of power } \\
\text { High sale value } \\
\text { Conveys prestige on its owner }\end{array}$ & $\begin{array}{l}\text { Liable to be stolen, more so } \\
\text { recently (Kababish, Kawahla, } \\
\text { Hawawir, Meidob, Zeiyadiya, } \\
\text { Zaghawa) }\end{array}$ \\
\hline Goats & $\begin{array}{l}\text { Survive on almost any vegetation } \\
\text { Requires little care } \\
\text { Provides milk } \\
\text { Milk is churned to a special butter } \\
\text { for children by the Haedendowa } \\
\text { Provides hair } \\
\text { Easily saleable for petty cash } \\
\text { Provides meat and often } \\
\text { slaughtered for prestigeous visitors } \\
\text { Useful in maintaining family ties } \\
\text { when ceded as gifts }\end{array}$ & $\begin{array}{l}\text { Accused of accelerating } \\
\text { degradation because it grazes on } \\
\text { almost any vegetation } \\
\text { Susceptible to disease } \\
\text { Vulnerable to drought suffering } 25 \% \\
\text { losses in } 1984-1985\end{array}$ \\
\hline Sheep & $\begin{array}{l}\text { Less hardy than camel and } \\
\text { manageable only under good } \\
\text { grazing conditions } \\
\text { Grazes over a large radius to } 40 \mathrm{~km} \\
\text { Drinking interval } 4 \text { days } \\
\text { Short generation cycle } \\
\text { Easily marketable and cash sales } \\
\text { mean camels do not need to be } \\
\text { sold (sheep are the coat of camels, } \\
\text { Kababish proverb). } \\
\text { Good investment with quick returns } \\
\text { in good years }\end{array}$ & $\begin{array}{l}\text { Susceptible to disease } \\
\text { Vulnerable to drought with } \\
\text { estimated loss in } 1984 \text { of } 25 \%\end{array}$ \\
\hline Cattle & $\begin{array}{l}\text { Thrives well under semi-arid } \\
\text { conditions if good grazing } \\
\text { available } \\
\text { Best milk breeds are owned by } \\
\text { Abbala (Butana and Kenana, of } \\
\text { all rural nomadic groups), as } \\
\text { compared to the zebu type raised } \\
\text { by Baqqara } \\
\text { Supplies milk for sedentary part } \\
\text { of nomadic family } \\
\text { Butter and ghee processed from } \\
\text { milk for home consumption or } \\
\text { sale } \\
\text { Productive and young readily } \\
\text { saleable } \\
\text { Good internal and external } \\
\text { market }\end{array}$ & $\begin{array}{l}\text { Grazes a limited radius of } 8-12 \mathrm{~km} \\
\text { and devastates pasture around } \\
\text { settlements and permanent water } \\
\text { Needs intensive management }\end{array}$ \\
\hline
\end{tabular}

\section{Baggara cattle}

An overwhelming proportion of the cattle of Kordofan and Darfur regions are of the western Bagqara type. They occur in many colours including white, grey, black, brown, fawn, grey and white, and black and white. Different pastoral groups have distinct preferences for particular types of cattle. These preferences are reflected in the composition of their herds which tend to be dominated by a single breed or colour type. The dominant colour of animals owned by the Habbaniya, Ta'aisha and Bani Halba tribes, for example, is white; that of the Rizayqat in eastern-southern darfur is red. Various other coat colours occur, including black, yellow, grey, orange and dun. Broken patterns are also exhibited, often of three and sometimes of four colours on one animal. Flecks, blotches and spots of black or brown on white or grey ground are common, as is the reverse pattern. Darker points on light backgrounds also occur. Hair is short and fine, the skin thin and pigmented. The dewlap is well developed and often extensively pleated. The umbilical fold in females is comparatively small. The sheath in males is triangular in shape.

Horns are ovoid or circular in cross-section, curve upward and outward from the poll, before turning in at the tip. They are heavier on males than on females and in the former often lack the inward curve. In mature females they range in length from 16 to $45 \mathrm{~cm}$ with an average of $29 \mathrm{~cm}$. Average length of horn in males is $31 \mathrm{~cm}$. True polled animals are uncommon but loose hanging horns and scurs occur in a number of animals. Ears are long and drooping. Facial profile tends to be straight. 
The hump in females is generally small and cervico-thoracic in position. It is larger in males but still small by the standard of many zebus. The back is straight or slopes down from the sacrum, hindquarters development is poor, the rump sloping steeply to the tail, which is long. Average height at withers in mature males is $143 \mathrm{~cm}$ and in females $132 \mathrm{~cm}$. Live weight of mature males averages $367 \mathrm{~kg}$ in the range of 298 to $493 \mathrm{~kg}$. Females average $286 \mathrm{~kg}$ within the range of 200 to $365 \mathrm{~kg}$.

Western Baggara cattle are used principally for milk production; males are also used as pack animals and as riding animals for herding. Baggara cattle are the main source of meat production, whether for local use or export.

\section{Kenana}

The characteristic colour of the Kenana is light blue-grey, with gradations from nearly white to steel-grey, shading to nearly black on head, neck, hump, hindquarters and legs. The points (muzzle, horns, tail tip and hooves) are black. The individual coat hairs are black at the base and white, or occasionally (and usually in the young) red at the tip. The darker colours and darker areas are due to the hairs having a broader black band.

The horns are usually short, $15-20 \mathrm{~cm}$ in length, with a maximum of $30-35 \mathrm{~cm}$ and measure $5 \times 6 \mathrm{~cm}$ at the base in females and $6 \times 7 \mathrm{~cm}$ in males. Loose horns are common. The face is thin with a convex, but occasionally straight, profile. The hump is cervico-thoracic in position, large in the male with a tendency to hang to one side, smaller in the female and castrates. The dewlap is large, as is the sheath in males. The sacrum is higher than the withers. The udder is well-shaped and of good size with large well-placed teats. Mature cows can reach $130 \mathrm{~cm}$ and weigh as much as $450 \mathrm{~kg}$. Bulls reach $141 \mathrm{~cm}$ and weigh up to $550 \mathrm{~kg}$.

The Kenana is found east of the confluence of the Blue and White Niles at Khartoum and south and east to the Ethiopian border. It is most common in the Blue Nile (Fung), White Nile and Gezira provinces in a' triangular area roughly bounded by Sennar, Singa, Roseires and Kosti and lying approximately between latitudes $10^{\circ}$ and $13^{\circ} \mathrm{N}$ and latitudes $32^{\circ}$ and $34^{\circ} \mathrm{E}$. The total population of Kenana cattle has been estimated at two million head: they are owned mainly by nomadic and semi-nomadic tribes including the Kenana, the Rufa'a el Hoy and the Beni Meharib. Traditionally they are used as dairy, beef and draught animals.

White Nile cattle are said to have the same production characteristics as the Kenana and to trace back to them. Similar characteristics are exhibited by the Kababish, or Dar er Reih, cattle.

\section{Kenana}

The region to the east and north of Khartoum is called the Butana. Its northern section is the home of two important tribes, the Batahin and the Shukriya. Butana cattle, considered as one of the best dairy cattle in the country with yields of $1,900 \mathrm{~kg}$ per lactation, form the majority of these tribes' holdings.

The Butana resemble the Kenana in physical characteristics except for the dominant colour, which is red.

\section{Red Bororo (Um Bororo)}

These cattle are of the long lyre-horned West African zebu type. Introduced by Bororo (a clan of the Fulani group) immigrants from West Africa in the 19th century, they are commonest in the western provinces but now extend into Kassala province. The majority 
of animals are of an even deep cherry-red colour. The skin is loose and supple and the dewlap and sheath or navel fold well developed, allowing a large area for evaporative cooling. They are of relatively large size, females being $130-135 \mathrm{~cm}$ at the withers and weighing $250-300 \mathrm{~kg}$ and males $140-150 \mathrm{~cm}$ and $450 \mathrm{~kg}$ or more. They are well adapted to arid conditions which they are able to overcome by their ability to move long distances rapidly in search of feed and water.

Bororo cattle are considered to be intelligent and obedient of their owners but are nervous and flighty in the presence of strangers. A few animals are castrated for pack purposes and bulls are occasionally ridden but, in the Sudan, the breed is considered temperamentally unfit for work. Also in the Sudan it is considered that the Um Bororo produces only small quantities of milk in a short lactation and its beef is of poor quality. In its native areas in Nigeria and Chad it is considered a productive multi-purpose animal, providing milk, meat and power for drawing water, as well as being used in a variety of ceremonial roles.

\section{Minor breeds}

Several minor breeds can be identified in different areas of the country. A few have small populations in the current study area.

Gash or Erashi. This type is said to represent $47 \%$ of the cattle population of the Eastern Region. They are an early indigenous Beja type kept mainly by the Hadendowa and Beni Amer tribes in the Gash and Tokar Deltas. The colour is white with black extremities. They are considered to be good milk producers.

Karoor. Representing $5 \%$ of the cattle population of the Eastern region and originally from Eritrea this type is now found in many Beja herds, particularly in the Gash Delta. It is a shorthorned zebu type which varies in colour but usually shows mixtures of red, white and black. It is not a good milk animal.

Nuba Mountain or Kalib. The original cattle of the Nuba were small, black, humpless animals. Indiscriminate cross-breeding, especially with the Baggara type, has produced an intermediate type known as the Nuba Mountain breed. These are small animals with a short head, broad muzzle and short horns that occasionally hang loose. There are many colour varieties. They are said to be somewhat tolerant of trypanosomosis, having inherited the trait from their humpless ancestors. Their main function is ceremonial, as many as 50 head being slaughtered at major wrestling ceremonies.

\section{Sheep}

The majority of sheep belong to a general type classed as Sudan Desert. There are, however, many variations and some groups show more or less influence of western and Nilotic blood.

\section{Sudan Desert}

The Sudan Desert sheep in its purest state is found from Darfur in the west to Blue Nile in the east. It is a large animal with useful meat and carcass characteristics: in the Sudan it is considered to be a good animal for export purposes. Weights of $65-70 \mathrm{~kg}$ can be achieved but $40-50 \mathrm{~kg}$ is more normal. Some strains are good milk producers.

There are several tribal types. In Kordofan these are the Kabashi and the Hamari. The Hamari is mainly from the En Nahud area and is tall and thin-tailed with large horns: the colour is red or brown. The Kabashi, commonest around Soderi, Bara and El Mazrub, is white, heavier than the Hamari and is a good milk producer.

The main tribal breeds in the Gezira are the black and white Dubasi, the sandy-red Shugor (or Ashgar in the plural), and the cream and more heavily built Watish. The Gezira types tend to have similar production characteristics although the Shugor produces significantly 
In Blue Nile province the Sudan desert type is known as the Baladi (= local). Sheep in the Eastern Region are of two principal subtypes: the Beja raised by the tribes of the same name in Red Sea Hills and the coastal plain while the Butana is raised by the Shukriya and is a pale sandy colour. The Beja is relatively small in size while the Butana is a very large sheep with a strong flock instinct.

\section{Other types}

Nubi or Garaq. This is a small sheep and produces little milk. Although mainly confined to the Nuba Mountains it is owned by Arab tribes.

Western Baggara. These sheep are smaller than the Sudan Desert and seem to be intermediate between Sudan Desert and Sudan Desert $x$ Sudan Nilotic. They are of good mutton type, generally shorter in the leg than the Sudan Desert and having a thinner tail. The rib cage is well sprund and they have quite well-developed hindquarters, although there is some tendency for the rump to slope off. Under local management conditions, carcass finish is poor, with little or no fat and a dressed carcass percentage of 33-56\% with an average of about $41 \%$. The predominant colour is red, varying in shade from sand to almost black; white occurs fairly frequently and various combinations of red and white are also common. Black and black and white are also present and it is possible that these colours may have been introduced as a result of infusions of Arid Upland or Zhagawa and of Um Bororo blood. The coat consists of coarse hair. Males are mainly horned, these being ribbed, growing out from the head in a regular spiral: they may be as long as $60 \mathrm{~cm}$ measured on the curve. Some males are only lightly horned or carry loose scurs. Lighter. slimmer horns are carried by about $5 \%$ the females. Ears are long and pendulous in the range $12-18 \mathrm{~cm}$. The neck and legs are long. The mean shoulder height in females is 76. $\mathrm{cm}$.

Um Bororo or Fulani. These sheep are fairly numerous in Southern Darfur. Large flocks of migrant sheep from Chad an the Central African Republic swell the numbers in the dry season. They are a large, long-legged type, characteristically with black forequaters and white hindquarters.

Zhaqawa or Arid Upland. These black sheep (except for a white tail tip) have rather long hair, are tall and leggy and are owned by the tribe of the same name that inhabits northwest Darfur. They are very similar to the Black Maure sheep of the western Sahel in Mauritania and Mali.

\section{Goats}

The three main type of goats in the Sudan can be described as the Nubian, Sudan Desert and Nilotic. Some exotic goats have been imported, including the Swiss (by missionaries in the early 1900s) which is considered to be a good milk producer, and the Anglo-Nubian (with British assistance in the mid 1970s).

\section{Nubian}

This is a large, relatively long-legged goat with extremely long and pendulous ears. The hair is also usually long, black in colour except for the ears which are grey. The Nubian is essentially an urban goat, living well by scavenging on human waste. It is commonest in the central areas of the country, particularly along the Nile valleys. Milk yield is often in the region of 2.5-3.0 litres a day, much of which is taken for human use, the kid or kids being deprived of it by the simple expedient of putting a bag on the udder and allowing only limited access.

\section{Sudan Desert}

A large long-legged goat, considered to be relatively prolific and a good meat goat, if somewhat lacking as a dairy goat. Its essential characteristic is its ability to survive the harsh climatic and limited nutritional environment of the northern Sudan desert areas. 


\section{Baggara}

The goats of the Baggara tribes of Southern Darfur approximate closely to the Sudan desert type. They are highly prolific and are good producers of meat and milk. Coat colour is variable, ranging from white, through light shades of grey and silver to fawn, brown, red and black. The coat consists of fine short hair but occasionally some animals with long hair are seen. The long hair may be general over the body but more commonly it is confined to the hindquarters and legs. Beards are present in many older females and begin to sprout in males from about four months of age. Manes, either to the shoulder or down the length of the back, occur but are not common. Horns are present in about $95 \%$ of all goats, being much larger and flatter in males than in females in which normal growth is upward and backward. Average shoulder height of mature females is $65.5 \mathrm{~cm}$ and weight $32.7 \mathrm{~kg}$.

\section{Minor types}

The Habashi or Abyssinian goat is found in the Central region and is thought to have been introduced during the First World War by troops from Eritrea: it is a small hairy goat with dark markings on the shoulders and flanks. The Hadalat and Baladi types of the Red Sea and Gash areas are smaller than the Nubian.

\section{Camels}

The two major types of the one-humped camel are the riding and baggage or pack types. There has been much interest in the riding type in recent years and some attempts to select for speed have been made as a market has developed for racing camels for export at very high prices to the Arabian Peninsula and Gulf area.

\section{Pack camels}

The main distinction is between the so-called Arab and the Rashaidi. The former, a native of Northern Kordofan and Darfur, is bred by the Kababish, Hamar, Kawahla, Zhagawa, Meidob, Shenabla and Zeyadiya: it is a large, heavily-built animal, grey to red in colour, weighing $400-500 \mathrm{~kg}$ when mature and capable of carrying almost $300 \mathrm{~kg}$ for up to $30 \mathrm{~km}$ in a day.

The typical Rashaidi is the rufous coloured animal bred by the tribe from which it takes its name. They are large and are renowned as meat animals as well as producing fair quantities of milk. They are less hardy than the majority of pack animals and do not thrive on less than good grazing. They are less numerous than the Arab type and are bred, in addition to the Rashaidi themselves, by the Shukriya, Lahawin and Batahin.

\section{Riding camels}

The most famous types are bred east of the Nile.

The Anafi is bred by the Rashaidi and has been selected for speed rather than for stamina but over distances of up to $40 \mathrm{~km}$ they are unequalled as personal transport animals. It is a leggy animal and ligth in build. The colour is white to pale cream.

The Bishari camel of the Beja tribes of the Red Sea area, which also extends to Eritrea, is the other major riding type. It is also reputed to be a good milk animal. Many sub-types are recognized by the tribes that own them but they differ little the one from the other.

\section{Equines}

The 1975-1976 aerial survey estimated almost 100,000 horse in the Sudan, most in Southern Darfur and Southern Kordofan and 789,000 donkeys.

\section{Horses}

Two major types of native horse are usually recognized. The Baladi is the western Sudan type and is owned mainly by the Baggara tribes: it is rather small with a withers height of about $12-13$ hands $(120 \mathrm{~cm})$. The Baladi has been the subject of long years of attempted improvement, firstly for military purposes and more recently for racing: English and French thoroughbreds were first imported and then bloodstock from Kenya. The resulting Sudan Countrybred is not widespread and limited to a small coterie of wealthy traders and civil servants. 
The Dongolawi takes its name from the town of the same name in Northern Province. It is believed to have been introduced from Egypt in the late 18th century. It is bigger than the Baladi, has a pronounced Roman nose, and is reputed to be a fast runner.

\section{Donkeys}

The commonest donkey, sometimes known as the Makadi or Darawi type, is the small grey pack animal which is the ubiquitous beast of burden in northern Sudan rural areas. This grossly mistreated beast, rarely reaching $105 \mathrm{~cm}$ at the withers and almost never weighing $120 \mathrm{~kg}$ is expected to carry as much as or more than its own weight in miscellaneous goods for 20 or $30 \mathrm{~km}$ to market and then carry its owner on the way back, day in and day out, on the little nutrition it can glean when it is not staggering along under these mundane burdens.

A totally different type is the much more statuesque, usually white, Syrian or Rifawi donkey, growing to $120 \mathrm{~cm}$ at the withers and weighing up to $160 \mathrm{~kg}$ or more. This is essentially an urban animal and a personnel carrier, the person in question usually being a merchant of no little consequence. Its habitual gait is a trippling trot which carries it along at $6-8 \mathrm{~km} / \mathrm{hr}$ but its contribution to the national economy is in no way comparable to that of its supposedly humbler, much smaller and often disdainfully disregarded grey brother.

Crosses between the two principal donkey types are dubbed the Sudanese Riding Donkey whose attributes are nearer to those of the Rifawi than the common grey. The Equus asinus $x$ Equus caballus hybrid, commonly known as the mule, was once fairly common in the Sudan, especially as a military transport animal but is now very seldom seen.

\section{Livestock productivity}

Sudanese livestock are well adapted to the harsh environment in which they are expected to survive, produce and multiply. They travel long distances in search of their daily feed, survive on a watering regime which allows them access to liquid only at irregular intervals of several days, are resistant to many diseases, and adjust their reproductive rate to the prevailing but usually unfavourable environmental conditions.

Under favourable conditions, however, priority is given to the multiplication of the species and conception and birth rates increase to take advantage of the improved feed availability. Weight losses are recovered by the phenomen of compensatory gain as soon as rain produces grass. For long, the accepted wisdom has been that traditional owners are backward and ignorant, but in reality they have adopted sophisticated management techniques that are well-suited to the prevailing conditions. This does not mean that they get what might be considered high productivity from their animals. Indeed they may not be attempting to do this, as survival is a delicate balance between the science of the totally improbable and the art of the equally unlikely possible. Some results obtained under experimental conditions hint at the real potential of Sudan's indigenous livestock but there is much to do before these capabilities become economically and ecologically feasible.

\section{Herd structures}

The sex and age composition of a herd or flock, far from being something which happens by chance, is a tightly controlled factor that provides a good indication of the production objectives of the owners and the capabilities of the animals.

There are few detailed and really quantitative studies of cattle herd structure in the Sudan, especially for the more nomadic tribes. Those that have been done, however, always show a high proportion of females, in line with the principal production objective which is milk for home consumption and for conversion to ghee. Cows of breeding age are usually 
equivalent to about $35-40 \%$ of the herd (Table 2) and younger females and calves form about the same percentage. Mature males comprise about $6-8 \%$, even in those groups for which they are used as transport and pack animals. Breeding and pack males are selected early in life and the others sold at ages of about two years: in some tribes, when environmental circumstances prove extremely difficult, males are sold at even younger ages.

There are few differences in herd structure related to breed type but their are clear differences due to the environment. In Southern Darfur the female proportion of the herd is about $70 \%$ but in the drier northern parts of the Butana this proportion can be higher than $90 \%$. An intermediate situation is found in irrigated areas. In herds in very dry areas, males are sold very young, while growing females are relatively numerous, in part due to good fertility rates and in part to low early mortality.

Table 2 - Cattle herd structures (\%)

\begin{tabular}{|c|c|c|c|c|c|c|c|c|c|c|c|c|}
\hline \multicolumn{13}{|c|}{ Breed type or area and sex } \\
\hline \multirow[t]{2}{*}{$\begin{array}{l}\text { Age } \\
\text { (years) }\end{array}$} & \multicolumn{2}{|c|}{ Baqqara } & \multicolumn{2}{|c|}{ Butana } & \multicolumn{2}{|c|}{ Kenana } & \multicolumn{2}{|c|}{$\begin{array}{l}\text { Southern } \\
\text { Darfur }\end{array}$} & \multicolumn{2}{|c|}{$\begin{array}{l}\text { Gezira and } \\
\text { Managil }\end{array}$} & \multicolumn{2}{|c|}{$\begin{array}{l}\text { Eastern } \\
\text { Region }\end{array}$} \\
\hline & Male & Female & Male & Female & Male & Female & Male & Female & Male & Female & Male & Female \\
\hline$<2$ & 15.5 & 20.8 & 5.8 & 22.1 & 15.5 & 21.3 & 17.1 & 20.8 & 14.0 & 16.9 & 3.9 & 31.6 \\
\hline $2-4$ & 6.2 & 14.8 & 5.8 & 15.6 & 5.3 & 15.2 & 10.2 & 16.8 & 3.3 & 17.2 & 2.5 & 20.2 \\
\hline $4-$ & 5.7 & 26.0 & 7.6 & 28.1 & 8.0 & 24.3 & 3.8 & 31.3 & 1.6 & 47.0 & 1.7 & 40.1 \\
\hline & - & 11.0 & - & 6.8 & - & 10.4 & - & - & - & - & - & - \\
\hline Overall & 27.4 & 72.6 & 19.2 & 72.6 & 28.8 & 71.2 & 31.1 & 68.9 & 18.9 & $81 . \dot{1}$ & 8.1 & 91.9 \\
\hline
\end{tabular}

Note: a) Over 4 years in regions

Sources: Wilson and Clarke 1975, AOAD 1983, Oxfam 1989

In small ruminant flocks (Table 3 ) there are always more than $75 \%$ of females, with regional differences showing the same trend as for cattle. Adult males often comprise only $2 \%$ of the flock in goats and $3-4 \%$ in sheep. The example of flock structures for both sheep and goats from the Gezira, which show very few females in the age class 7-15 months, is somewhat anomalous and can be considered to be due to the effects of drought just before the survey was made.

The proportion of males is higher in most camel herds than for the ruminant species. This is mainly because of the transport function but also because camels for meat are often sold to Egypt, where the market and the long trek across the desert involve in getting animals to that market, require that animals be larger and stronger. Breeding females in camel herds are rarely more than $33 \%$ of the total.

There is a clear dichotomy of structure in donkey herds. In rural areas, where herds serve for both transport and as a breeding reserve the structure may be of approximately equal proportions of male and female or slightly in favour of the latter. In urban areas the work demand is such that males are best suited to the system and they often account for $80 \%$ or more of the total numbers in these areas.

Table 3 - Regional small ruminant flock structures (\%)

\begin{tabular}{|c|c|c|c|c|c|c|}
\hline \multirow{3}{*}{$\begin{array}{l}\text { Species } \\
\text { and } \\
\text { age (months) }\end{array}$} & \multicolumn{6}{|c|}{ Region and sex } \\
\hline & \multicolumn{2}{|c|}{ Darfur } & \multicolumn{2}{|c|}{$\begin{array}{l}\text { Gezira and } \\
\text { Managil }\end{array}$} & \multicolumn{2}{|c|}{$\begin{array}{l}\text { Eastern } \\
\text { region }\end{array}$} \\
\hline & Male & Female & Male & Female & Maie & Female \\
\hline \multicolumn{7}{|l|}{ Sheep } \\
\hline$<7$ & 8.8 & 13.4 & 14.4 & 20.7 & 6.1 & 17.3 \\
\hline $7-19$ & 9.2 & 15.3 & 1.9 & 7.6 & 5.6 & 31.8 \\
\hline$>19$ & 4.2 & 49.1 & 1.7 & 53.7 & 3.5 & 35.7 \\
\hline Overall & 22.2 & 77.8 & 18.0 & 82.0 & 15.2 & 84.8 \\
\hline Goat & & & & & & \\
\hline$<7$ & 14.8 & 18.5 & 10.8 & 20.2 & 5.2 & 18.4 \\
\hline$\&-15$ & 7.2 & 16.0 & 1.9 & 9.2 & 3.8 & 37.4 \\
\hline$>15$ & 1.6 & 41.8 & 1.0 & 56.9 & 1.7 & 33.0 \\
\hline Overall & 23.6 & 76.3 & 13.7 & 86.3 & 10.7 & 88.8 \\
\hline
\end{tabular}




\section{Productivity}

Cattle reproduction in years of average rainfall and feed availability hardly differs from one area to another (Table 4). Kenana and Butana females appear to be slightly younger at first calving, at 3.5-4.0 years, than do the Baggara animals, in which first calving may be delayed to 5.0 years. Subsequent intervals between calvings may also be slightly shorter in Butana than in the other breeds. Total lifetime production of young is therefore less in Baggara cattle than in the other major groups, at least in the traditional systems. On research stations no real differences in reproductive performance of the three major types have been noted.

Table 4 - Reproductive performance of cattle in traditional and modern systems

\begin{tabular}{|c|c|c|c|c|}
\hline \multirow{2}{*}{ Parameter } & \multicolumn{4}{|c|}{$\begin{array}{l}\text { Breeds in traditional } \\
\text { system }\end{array}$} \\
\hline & Baqqara & Butana & Kenana & $\begin{array}{l}\text { Research } \\
\text { stations }\end{array}$ \\
\hline Female fertility rate $(\%)$ & $50-60$ & $55-60$ & $55-60$ & 85 \\
\hline Age at first calving (months) & 59 & 47 & 43 & 38 \\
\hline Productive life (years) & $7-8$ & $7-8$ & $7-8$ & 9 \\
\hline (number of calves) & $4-5$ & $4-6$ & $4-6$ & 7 \\
\hline Calving interval & 20 & 18 & 20 & 15.4 \\
\hline
\end{tabular}

Both reproductive performance and mortality rates are subject to climatic variations. According to the normal statistical sources (Ministry of Animal Resources, 1989), the period 1983-1985 was one in which low reproductive and high mortality rates prevailed (Table 5). It seems that calving rates were some $20 \%$ less than in "normal" years and mortality rates much higher, with losses of $40 \%$ adults and $50 \%$ young being recorded. Climatic conditions continued to be unfavourable up to 1988 and the forced sale of animals had further consequences on herd structure and productivity. Deaths in young are often in excess of $10 \%$ in the first year, however. Adult mortality is usually lower and often about the same as the off-take rate.

Baggara cattle tend to be smaller than the Kenana and the Butana as well as having slower relative growth rates (Table 6). Weight gains in all breeds are less than optimal, however, and often negative in the dry season: even during the favourable period much of the energy is used in compensatory gain and in the long treks to good grazing areas and to find water. The Butana are considered to be the best milking animals while the Baggara, once again, have lower performance with shorter lactation periods and a smaller daily output. In general the productivity of Sudanese cattle is low, as in many other African countries, and for much the same reasons. These reasons are the harsh natural environment, limited feed resources which are often of very poor quality in the dry season, and inadequate health care and services. 


\section{LIVESTOCK RESOURCES (CONTINUED)}

Table 5 - Cattle herd dynamics in the period 1981-1982-1988-1989

\begin{tabular}{|c|c|c|c|c|}
\hline \multicolumn{5}{|c|}{ Parameter (\%) } \\
\hline Yeer & $\begin{array}{c}\text { Fertily } \\
\text { rate }\end{array}$ & $\begin{array}{l}\text { Calt } \\
\text { mortality }\end{array}$ & $\begin{array}{l}\text { Of take } \\
\text { rate }\end{array}$ & $\begin{array}{l}\text { Herd } \\
\text { mortalty }\end{array}$ \\
\hline $1981 / 1982$ & 62 & 10.3 & 7.1 & 7.0 \\
\hline $1982 / 1983$ & 60 & 11.0 & 8.1 & 8.1 \\
\hline $1983 / 1984$ & 54 & 11.6 & 9.0 & 9.0 \\
\hline $1984 / 1985$ & 49 & 14.5 & 10.0 & 10.5 \\
\hline $1985 / 1986$ & 52 & 11.5 & 6.0 & 9.1 \\
\hline $1986 / 1987$ & 56 & 10.7 & 7.5 & 8.9 \\
\hline $1987 / 1988$ & & e data miss & for this ye & \\
\hline $1988 / 1989$ & 61 & 10.5 & 7.8 & 8.6 \\
\hline
\end{tabular}

Table 6 - Cattle weight gains and milk production in the major systems

\begin{tabular}{l|r|r|r|r}
\hline \multicolumn{5}{c}{ Tradtional secter and breed } \\
\hline Parameter & Eaggara & Butana & Kenana & $\begin{array}{r}\text { Regearch } \\
\text { stations }\end{array}$ \\
\hline Weight at birth (kg) & 18 & 24 & 23 & 24 \\
Weight at 1 yr (kg) & 103 & 180 & 160 & n.a. \\
Male age at sale (yr) & 5 & 4 & 4 & 2 \\
Weight at sale (kg) & 330 & 380 & 360 & 450 \\
Daily gain (g) & 170 & 244 & 230 & 580 \\
Lactation period (d) & 230 & 280 & 230 & 300 \\
Lactation yield (kg) & 350 & 1400 & 1100 & 1550 \\
\hline
\end{tabular}

Source: FAO 1986

Small ruminants are comparatively better at transforming the natural resources to economic products. Fertility rates, with non-seasonal breeding are usually in excess of ' $100 \%$ and twin births in sheep overall may be $4-6 \%$ of all parturitions, while in goats they are 8-12\%: multiple births in Southern Darfur may be more than double these generalized Sudan data. There is very early offtake of males in both goats and sheep (Table 7), animals often being slaughtered or sold at under 12 months and very few males older than two years remain in the flocks. Mortality rates in young animals may be as high as $20 \%$ but offtake rates (as home consumption, for social reasons and as sales) are often as high as or in excess of $30 \%$. 
Table 7 - Basic productivity parameters of small ruminants

\begin{tabular}{l|c|c|c|c|c}
\hline \multicolumn{1}{|c}{ Parameter } & \multicolumn{2}{c}{$\begin{array}{c}\text { Sheap } \\
\text { Traditional }\end{array}$} \\
\hline Improved Gezltra & Red Sea & Traditional \\
\hline Age at first birth (months) & 17 & 90 & 87 & 64 & 75 \\
Productive life (years) & $5-6$ & 6 & & & $5-6$ \\
(parturitions) & 4 & 8 & 5 & 4 & 8 \\
Weight at birth (kg) & 2.7 & 3.5 & 3.0 & 2.6 & 2.5 \\
Male age at sale (months) & 24 & 18 & 20 & 24 & 18 \\
Weight at sale (kg) & 35 & 45 & 40 & 32 & 23 \\
Weight gain (g/d) & 45 & 77 & 50 & 40 & 40 \\
Lactation length (days) & 210 & 200 & 200 & 180 & 210 \\
Lactation yield (kg) & 140 & 250 & - & - & 155 \\
Mortality, young (\%) & 13.9 & - & - & - & 14.0 \\
herd (\%) & 10.5 & - & - & - & 10.6 \\
Off take (\%) & $24-28$ & - & - & - & $26-28$ \\
\hline
\end{tabular}

Offtake from camel herds, as might be expected with reproductive rates of less than $50 \%$ and retention of males to advanced ages, is low. Female camels are, however, relatively good milk animals, not the least advantageous aspect of which is a very long lactation period. Low annual rates of reproduction are also compensated by a long life, often approaching 20 years and during which birth will be given to 6-7 young (Table 8).

More accurate data on the camel farming systems and their productivity were obtained from a survey conducted in 1987 on 836 Butana's herds (Table 9)

\section{Table 8 - Herd and productivity parameters of camels}

\begin{tabular}{|c|c|c|c|}
\hline Parameter & & Parameter & \\
\hline Males in herd < 4 yr $(\%)$ & $13-23$ & Fertility (\%) & $40-55$ \\
\hline$>4 \mathrm{yr}(\%)$ & $5-17$ & Age at first birth (years) & $5-6$ \\
\hline Females in herd $<4 \mathrm{yr}(\%)$ & $32-42$ & Productive life (years) & $12-14$ \\
\hline$>4$ yr $(\%)$ & $30-42$ & Birth interval (months) & $24-30$ \\
\hline Weight at birth $(\mathrm{kg})$ & 35 & Lactation length (days) & $450-500$ \\
\hline Adult male welght $(\mathrm{kg})$ & 475 & Lactation yield $(\mathrm{kg})$ & $1200-1800$ \\
\hline Weight gain (g/d) & $150-200$ & Mortality, young (\%) & 11.9 \\
\hline Off take (\%) & $6-7$ & herd $(\%)$ & 9.0 \\
\hline
\end{tabular}

Table 9 - Reproduction and production performance of Butana camel herds (from 1987's enquiry)

(Saint-Martin et al., 1990 - Maillard, 1982)

\begin{tabular}{l|rrrrrrr}
\hline Age class (year) & $3-4$ & 45 & $5-6$ & $6-7$ & $7-8$ & $8-9$ & $>9$ \\
\hline $\begin{array}{c}\text { Annual calving } \\
\text { rate (p.100) }\end{array}$ & 1 & 12 & 28 & 42 & 36 & 38 & 34 \\
\hline
\end{tabular}

( $n=2083$ breeding females)

Average age at first parturition : 6 years 6 months $(n=8847$ females) Average interval between births: 2 years 4 months $(n=2307)$

\begin{tabular}{l|cccccc}
\hline Age class (years) & 0.1 & 1.2 & 2.3 & 3.4 & 4.5 & $>5$ \\
\hline Mortality rate (p.100) & 12.2 & 4.1 & 3.0 & 2.3 & 2.5 & 4.0 \\
\hline . males & 13.4 & 4.3 & 3.4 & 3.1 & 3.3 & 4.9 \\
\hline . females & 10.9 & 4.0 & 2.5 & 1.5 & 1.8 & 3.3 \\
\hline Offtake rate (p.100) & 0.4 & 0.8 & 2.6 & 4.7 & 7.4 & 15.4 \\
\hline . males & 0.7 & 1.2 & 4.0 & 7.4 & 13.2 & 29.2 \\
\hline . females & 0.2 & 0.4 & 1.5 & 2.1 & 2.3 & 3.1 \\
\hline
\end{tabular}




\section{Wildlife}

Although much reduced in numbers, wild animals still comprise an important resource in the Sudan. This is for both good, as a potential source of tourist and hunting revenue and a traditional source of protein, and for evil, where they compete with man as crop robbers and with his animals for feed resources. The potential exonomic and aesthetic value of wildlife is only now being recognized and encouraged.

The wide range of habitat types in the Sudan is reflected in the wild fauna. Between 60 and 70 species of larger mammals have been recorded and more than 100 smaller mammals in the orders Lagomorpha, Chiroptera, insectivora, Rodentia, Carnivora, Hyracoidea and Primata (Wilson 1981, 1982). There are more than 900 bird species. Aeptiles, fishes and insects add to the rich variety. As for domestic livestock the best estimates of distribution and numbers are from the aerial surveys of the mid-1970s although there are some general indications of the areas where the major species of mammals are found (Table 10). There have, however, been rapid changes in the status of wildlife over the last 15-20 years due to inadvertent reduction and modification of habitat by the expansion of agriculture but aiso due to inadequate control of hunting and poaching. Several species once relatively common in Northern Sudan have been absent for very many years. Others found only in the north, such as addax, oryx, addra, Soemmerings gazelle, Nubian ibex, Barbary sheep, lion, leopard and cheetah are now either extinct or extremely rare.

Table 10 - Status and distribution of some larger wild animals in arid and semi-arid Sudan

\begin{tabular}{|c|c|c|}
\hline Scientific name & Common name & Distribution \\
\hline \multicolumn{3}{|l|}{ Endangered species } \\
\hline Acinonyx jubatus & Cheetah & Darfur, Blue Nile \\
\hline Addax nasomaculatus & Addax & Northern Darfur \\
\hline Ammotragus levia & Barbary sheep & Northern Darfur \\
\hline Capra ibex & Nubian ibex & Red Sea Hills \\
\hline Fennecus zerda & Fennec fox & Desert and very arid zone \\
\hline Gazella dama & Addra, Dama gazelle & Northern Darfur and Kordofan \\
\hline G. soemmeringi & Soemmering's gazelle & Kassala, Butana \\
\hline G. leptoceros & Rhim gazelle & Northern Darfur and Kordofan, Kassala \\
\hline Loxodonta africana & Elephant & Southern Darfur, Blue Nile \\
\hline Oreotragus oreotragus & Klipspringer & Hed sea Hills \\
\hline Oryx dammah & Scimitar-horned oryx & Northern Darfur \\
\hline Madoqua saltiana & Dik-dik & Southern Darfur, Blue Nile \\
\hline Panthera pardus & Leopard & Widespread \\
\hline Redunca fulvorufula & Mountain reedbuck & Red Sea Hilis \\
\hline Struthio camelus & Ostrich & Widespread \\
\hline Tragelaphus imberbis & Lesser kudu & Southern Darfur \\
\hline$T$. strepsiceros & Greater kudu & Jebel Marra, Blue Nile \\
\hline Vulpes spp," & "fox" & Kassala, Southern Kordofan and Darfur \\
\hline
\end{tabular}




\section{Others}

Alcelaphus buselaphus

Canis spp.

Cercopithecus aethiops

Colobus guereza

Crocodylus niloticus

Crocuta crocuta

Damaliscus tiang

Equus burchelli

Erythrocebus patas

Felis spp.

Gazella granti

G. dorcas

G. rufrifons

G. thomsoni

Giraffa camelopardalis

Hyaena hyaena

Hystrix cristatus

Hippotragus equinus

Kobus defassa

Lycaon pictus

Manis temmincki

Mellivora capensis

Orycteropus afer

Panthera leo

Papio anubis

Phacochoerus

aethiopicus

Taurotragus derbianus

Tragelaphus scriptus

Silvicapra grimmia

Syncerus caffer

Viverra civetta
Lelwel hartebeest Jackal

Vervet monkey

Colubus

Crocodile

Spotted hyaena

Korrigum, Tiang

Zebra

Red hussar, Patas

"cats", serval

Grant's gazelle

Dorcas gazelle

Red-fronted gazelle

Thomson's gazelle

Giraffe

Striped hyaena

Porcupine

Roan antelope

Defassa waterbuck

African hunting dog

Pangolin

Ratel, honey badger

Aardvaark

Lion

Baboon

Warthog

Giant eland

Bushbuck

Grimm's duiker

Buffalo

Civet
Southern Darfur

Kassala, Blue Nile, Darfur

Widespread

Southern Darfur

Nile and tributaries

Widespread

Blue Nile, Southern Darfur

Blue Nile

Widespread

Widespread

South Kordofan

Northern Darfur and Kordofan Kassala

Widespread

Blue Nile

Southern Darfur and Kordofan

Blue Nile

Widespread

Southern Darfur and Kordofan

Blue Nile, Southern Darfur

Southern Darfur and Kordofan

Southern Darfur

Widespread

Southern Darfur

Widespread

Southern Darfur and Kordofan

Widespread

Southern Darfur

Southern Darfur and Kordofan

Blue Nile

Widespread

Widespread

Camel population distribution (Butana)

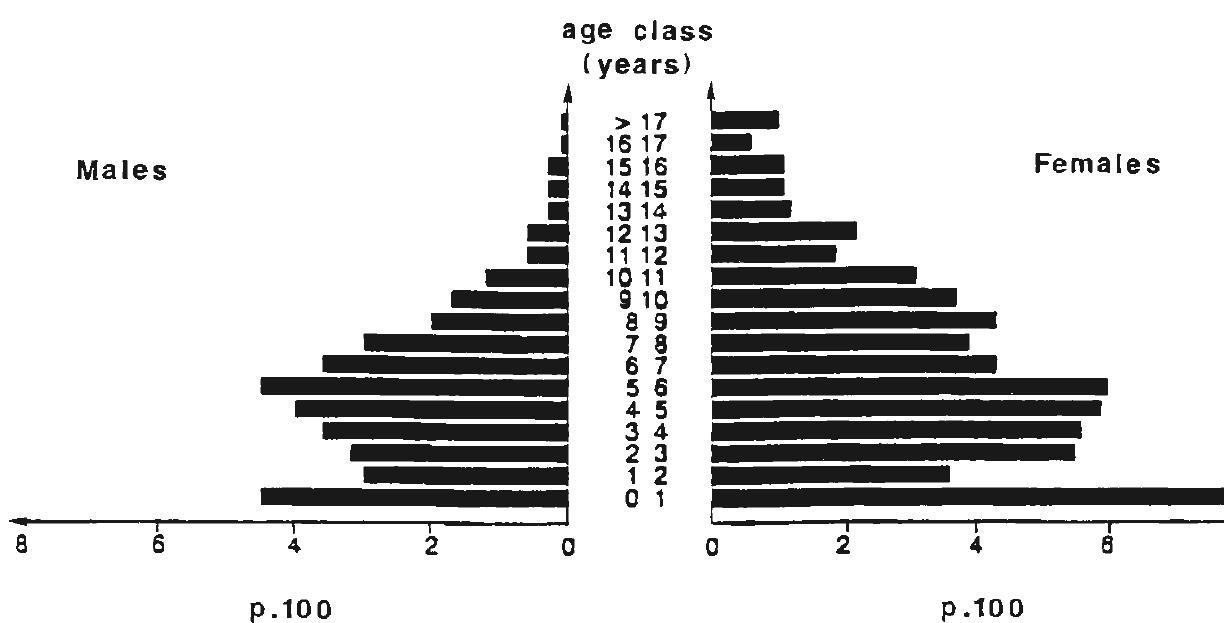




\section{BIBLIOGRAPHY}

Abu Sin M.E. - Breeding and marketing of racing camels in eastern Sudan: the case of Butana district. Camel forum working paper n_15. Mogadishu, Somali Academy of Sciences and Arts, 1986.

Abu Sin M.E. - Transformation process of camel breeding in the Sudan. In: Camel forum, Mogadishu. 1988.

ACSAD - Encyclopedia of animal resources in Arab countries - 5-D.R. (Sudan). 1983.

Ahmed F.A. - The growth of watish (Sudan Desert type sheep) at grazing on rainfed pasture and irrigated medicago sativa.

Um Benin livestock Res. Bull., 1979, 3.

Alim K.A. - Reproductive rates and milk yields of Kenana cattle in Sudan.

J. Agric. Sci., Camb., 1960, 5 5 : 183-188.

Atabani Y.I. - Studies on the Kenana cattle of the Sudan.

Sudan J. vet. Sci. Anim. Husb., 1960, (1) : 77-83.

Babiker M.M. - Abundance and economic potential of camels in the Sudan.

J. arid environment. 1984, $\underline{7}:$ 377-394.

Brockle - Hurst H.C. - Game animals of the Sudan. Their habitat and distribution. London, Gurney and Jackson, 1931.

Cunningham E.P. - Conservation of the Kenana and Butana breed. Rome, FAO Consultant report. 1983.

Davies (R.) - The camel's back: service in the rural Sudan. London, Murray, 1957.

El Amin F.M. - The dromedary camel of the Sudan. In: W.R. Cockrill, ed.- The camelid. An allpurpose animal. Uppsala, Sweden Scand. Inst. Afric. studies. 1979. Vol. 1.

El Amin F.M., Rizgalla Y. - Some studies on Sudanese sheep.

Sudan J. vet. Sci. Anim. Husb., 1976, 19 (1) : 26-33.

EI Naim Y.M. - Some reproductive and production traits of nubian goat. University of Khartoum. 1979.

Frankenburger - Animals in a farming system in North Kordofan, Sudan. Kansas farming systems research paper. 1984. (LRDC).

Gaili E.S.E., Ghaneau Y.S., Mukhtar A.M.S. - A comparative study of some carcass characteristics of Sudan desert shepp and goats.

Animal Production, 1972, 14 (3) : 351-357.

Gillespie I.A. - Riding camels of the Sudan.

The Sudan J. vet. Sci. Anim. Husb., 1962, $\underline{3}$ (1) : 37-42.

Gothi O.A.B. - Butana cow as a milk producer.

Sudan J. vet. Sci. Anim. Husb., 1968, $\underline{9}$ (1) : 270-84.

Hadart A.M.EL., Simpson M.C. - The economics of tropical milk production: a Sudanese case study.

East Afr. J. rural Development, 1970, 3 (1) : 57-68.

Hassaballa F.O. - The present status of wild life in the Sudan. The International Symposium on the Development of Animal Resources. 1988.

Khalafallah A.M., Khalifa H.A.A. - A study of some economic traits in a herd of Kenana cattle: service period, calving interval and gestation period.

WId Rev. Anim. Prod., 1983, 19 (1) : 39-44.

Mason I.L., Maule J.P. - The indigenous livestock of eastern and southern Africa. Commonwealth Bureau of Animal Breeding and Genetics CAB, Farnham Royal, U.K. 1960 (Tech. comm. n_14). 
McLeroy G.B. - Ecotypes and tribal breeds Sudan.

Sudan J. vet. Sci. Anim. Husb., 1961, 2 (2) : 101-65.

Osman A.H. - I. Studies in Sudanese indigenous cattle. II. Environmental factors influencing reproductive rates and milk production under range conditions.

Trop. Agric. Trinidad. 1972, $49: 2$.

OSMAN A.H. - Sudanese indigenous cattle breeds and strategy for their conservation and improvement. FAO Animal Production and Health paper 44. 1983.

Pilot survey of livestock Prod. and marketing in southern Darfur. Ministry of Agric. and Natural Res. Sudan. 1987.

Poetschke J. - Entwicklung der Tierproduction in der Demokratischen Repüblik Sudan. Neue wege der erschliefung und nutzung wiehwirtschaftlicher ressourcen.

Beitrage zur tropischen Landwirtschaft und Veterinarmedizin. Karl-Marx-Universitat Leipzig. DDR. $1982, \underline{20}$ (4) : 433-447.

Saeed A.M., Ward P.N., Light D., Durkin J.W., Wilson R.T. - Characteristic of Kenana cattle at Um Benein, Sudan. ILCA Research Report, 1987, 16.

Sidhamed A.E., Koong L.J. - Application of systems analysis to nomadic livestock production in the Sudan. In: J.R. Simpson, P. Evangelou, ed. - Livestock development in subsaharan Africa. Colorado, westview Press, Inc. 1984. P. 61-76.

Sulieman A.H., Wilson R.T. - Productivity of three subtypes of Sudan Desert sheep at El Huda research station, Sudan. In: R.T. Wilson, M. Azeb, ed. - African small ruminant research and development.

Addis-Ababa, International Livestock Centre for Africa. 1989. P. 552-64.

Uilenberg G. - Note on the number and species of livestock-Kordofan. Land use department files. 1957. (Unpublished Office Report).

Ward P.N. et al. - Reproductive pertormance of Kenana cows in Sudan.

Trop. Agric. Trinidad. 1988. $65: 73-6$.

Wilson R.T., Clarke S.E. - Studies on the livestock of southern Darfur, Sudan. 1. The ecology and livestock resources of the area.

Trop. Anim. Hlth. Prod., 1975, 7 : 165-87.

Wilson R.T. -Studies on the livestock of southern Darfur. V. Notes on camels.

Trop. Anim. Hlth. Prod., 1976, 10 : 19-25.

Wilson R.T. - Studies on the livestock of southern Darfur. III. Production traits in sheep.

Trop. Anim. Hith Prod., 1976, $\underline{8}$ : 103-14.

Wilson R.T. - Studies on the livestock of southern Darfur. IV. Production traits in goats. Trop. Anim. Hlth Prod., 1976, $\underline{8}: 221-32$.

Wilson R.T. - Studies on the livestock of southern Darfur, Sudan. VIII. A comparison of productivity indices for goats and sheep.

Trop. Anim. Hlth Prod., 1983, 15 (2) : 63-68.

Wilson R.T., Ward P.N., Saeed A.M., Light D. - Milk production characteristics of the Kenana breed of Bos indicus cattle in Sudan.

J. Dairy Sci., 1987, 70 : 2673-9. 


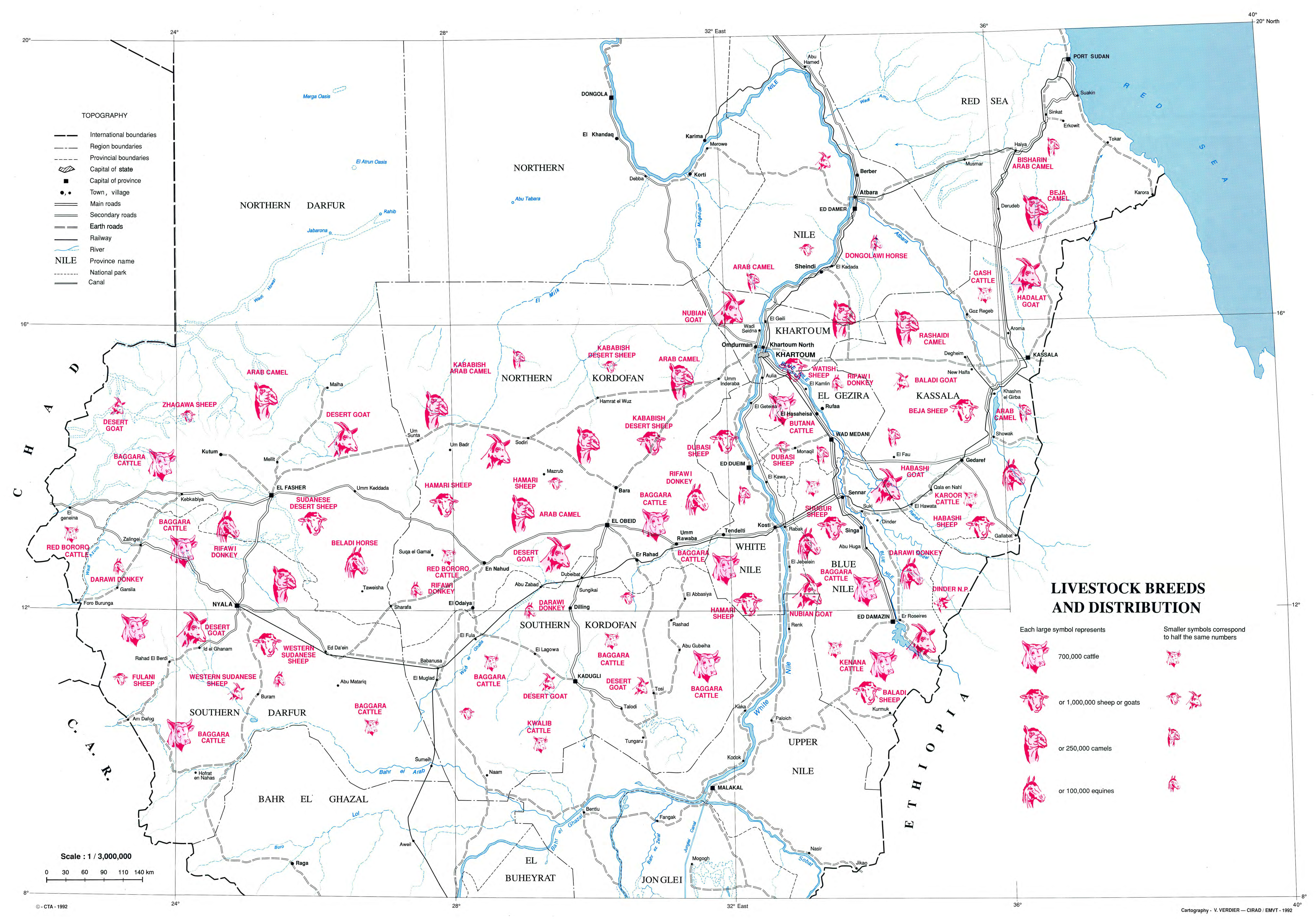




\section{ANIMAL HEALTH}

\section{G. UILENBERG}

Animal health. Uilenberg Gerrit, Verdier Véronique. 1993. In : Livestock production and sahelian rangelands potential: Republic of Sudan = Élevage et potentialités pastorales sahéliennes : République du Soudan. Darag A., Lamarque Georges. CIRAD-IEMVT - FRA. Wageningen : CTA-CIRAD-IEMVT, 31-32. ISBN 2-87614-088-8

Information on the livestock disease situation in the Sudan is mostly of an anecdotal nature and detailed studies showing prevalence and incidence data are few and far between

Some of the diseases which are of most concern are:

Viral: rinderpest, foot-and-mouth disease, African horse sickness, Rift Valley fever, sheep pox, Newcastle disease, rabies.

Bacterial: contagious bovine pleuropneumonia, contagious caprine pleuropneumonia, anthrax, blackquarter, brucellosis, haemorrhagic septicaemia, dermatophilosis, avian borreliosis.

Parasitic: trypanosomosis, tick-borne diseases, gastro-intestinal parasites, ectoparasites.

Additional common, important diseases are for instance:

tuberculosis, tetanus, contagious ecthyma, enterotoxaemia, leptospirosis, salmonellosis, Johne's disease, Gumboro and Marek's diseases.

This section is limited to a few of the major diseases which are most influenced by climatic and/or vegetational differences in their geographical prevalence. They are mainly vector-borne diseases.

\section{Trypanosomoses}

Some of the history is outlined by El Karib (1961). Bovine trypanosomosis was officially reported in the Sudan as early as 1904, while camel trypanosomosis made its first appearance in the official records two years later. It is believed that animal trypanosomosis must have existed much earlier than the records tend to show. "Guffar", the Arabic name for "surra" (Trypanosoma evansi infection) was apparently known in the country east of the Blue Nile for over 200 years and in the southern provinces the existence of local names for bovine trypanosomosis in the Nilotic languages indicates that it must have existed for a long period. ("Noi" in Dinka and Nuer, "Anoi" in Shilluk.)

A review of the situation of tsetse flies and trypanosomosis in the Sudan was given by Buxton (1955). His map of tsetse distribution, based on earlier reports by Lewis, is still largely valid today. Additional surveys of the situation in south-west Darfur, north-west Bahr El Ghazal, the Nuba Mountains and Kosti and Dueim districts were carried out from 1958 to 1960 (Uilenberg, 1960a, 1960b). Some of this work was reported by El Karib (1961) and further information was provided by Yagi and Abdel Razig, 1971, 1972, Abdel Razig and Yagi, 1973, and Hall et al., 1983, 1984.

Trypanosomoses are widespread in most parts of the country and most domestic animals are affected. The species so far encountered in the Sudan are: Trypanosoma congolense, T. vivax, T. brucei, T. evansi, T. simiae and T. equiperdum. 
T. congolense causes generally the most severe form of the disease in cattle in the Sudan. it also attacks horses, mules, dogs and camels, but has rarely been found in small ruminants in this country. Although it is generally accepted that $T$. congolense occurs mainly in areas within and immediately adjacent to the tsetse zones, there have been remarkable exceptions in the Sudan:

- a major outbreak of peracute bovine trypanosomosis in Upper Nile province in 1946 was due to T. congolense (El Karib et al., 1954, Buxton, 1955). Transmission was certainly mechanical in most parts of the province and the area carries an enormous population of Tabanidae and other biting flies (Buxton ,1955). Buxton (1955) reported T. congolense as far north as Kosti, and this species was the only one diagnosed in cattle on Abu Island in the White Nile (Kosti District), which is regarded as tsetse free (Uilenberg, 1960b).

T. vivax occurs in the tsetse zone, but also much further to the north. It has been diagnosed in sedentary herds along the White Nile up to almost the 14th parallel, in Dueim district, far from any known tsetse areas (Uilenberg, 1960b). It is certainly the most common species of trypanosome in cattle outside the tsetse zone, except for the sudd area in Upper Nile, where $T$. congolense is dominant. The disease in cattle is milder and more chronic than that caused by $T$. congolense. It has also been found in sheep and goats, but does not appear to affect these animals very much.

T. brucei affects equines, dogs, cattle and camels. In horses, camels and dogs it produces acute fatal trypanosomosis, while it is less pathogenic for cattle. Infection in small ruminants has not been documented in the Sudan. It has not been found outside tsetse areas.

T. evansi in the Sudan affects chiefly camels, causing surra (guffar in Arabic). Horses are also affected and suffer an acute disease similar to that caused by T. brucei. "Guffar" occurs where camels and biting flies, chiefly Tabanidae, are found together. This zone is limited to the north by a line stretching roughly from the 15th parallel in the west to the 18th in the east. North of this line camels exist without flies. South of the zone, which more or less stops at the northern tsetse belts, Tabanidae occur, but camels do not normally live there.

$T$. equiperdum, the cause of dourine, has been diagnosed on clinical and parasitological grounds in a donkey mare at Nyala (Uilenberg, 1961). This venereal disease of equines was known before to occur in northern and southern Africa. It may well have a more extensive distribution in tropical Africa, but little attention is paid to donkeys, and nervous disorders remain usually undiagnosed; the differential diagnosis includes viral encephalomyelitis as well as $T$. brucei and $T$. evansi infections. 
The main tsetse fly zone covers an area of over $200,000 \mathrm{~km}^{2}$ in the Sudan, south of a diagonal line from a point on the western border at almost the 11th parallel north to a point on the southern border at approximately $33^{\circ}$ longitude east. Further to the east tsetse populations are more scattered and occur on the eastern border as far north as the Kurmuk area (about $10^{\circ} \mathrm{N}$ ). Buxton's map shows the occurrence of flies even up to the 12th parallel on the border with Ethiopia. Moreover there were isolated pockets in the Koalib Hills in southern Kordofan, but these have now been eradicated.

Southern Darfur province is at the northern edge of the main African tsetse belt (Buxton, 1955). In the survey carried out from 1958 to 1960 tsetse flies were found considerably further North than was known before, as far as $11^{\circ} 4^{\prime} \mathrm{N}$ along the border with Chad and inside Chad even at $11^{\circ} 42^{\prime} \mathrm{N}$, $6 \mathrm{~km}$ to the west of the border (Uilenberg, 1960a). All flies caught were identified as Glossina morsitans submorsitans. Further surveys confirmed the existence of this tsetse fly in south-west Darfur (Yagi \& Abdel Razig, 1971, 1972; Abdel Razig \& Yagi, 1973); these authors, apparently unaware of the earlier reports, believed that their findings represented an extension of the northern limit of the belt.

More recent and extensive surveys of southern Darfur, including the whole length of the Bahr El Arab riverine zone, between 1979 and 1981, indicated that the distribution of the only tsetse species present in that area, Glossina morsitans submorsitans, had not appreciably altered in the meantime, although it was not found north of $10^{\circ} 15^{\prime} \mathrm{N}$ (Hall et al., 1984). Fly populations are most dense in the woodland savanna in the south west corner of southern Darfur, south of Wadi Umbelasha. Lighter infestations occur in the woodlands north of this riverine system, to a latitude of at least about $11^{\circ} 4^{\prime} \mathrm{N}$ (Uilenberg, 1960a), although the drier conditions prevalent since that time may have reduced tsetse distribution in the area. Buxton (1955) already regarded the isolated pockets of tsetse flies north of the main belts as consistent with the view that this part of Africa is becoming drier.

Cattle of the nomadic Baqqara tribes in Darfur enter the tsetse zones of south-western Darfur during the dry season, in search of grazing and water. Many go even further, into the north-west of Bahr El Ghazal province, and also cross into north-eastern Central African Republic. At the end of the dry season the infected herds go north again and are the cause of mechanically spread trypanosomosis in tsetse-free regions of Darfur. A similar situation occurs in southern Kordofan and northern Bahr El Ghazal province, where many Baqqara herds pass through tsetse pockets in the Jur Narrows, north of the main belt (Abdel Razig et al., 1968). On the other hand, mechanically transmitted bovine trypanosomosis is apparently also able to maintain itself, without direct contact with tsetse, in large parts of Upper Nile province, southern Kordofan, and in Blue Nile province. Tabanids are probably the main cuiprits.

\section{Ticks and tick-borne diseases}

These have acquired a greater importance in the Sudan since the introduction of more susceptible exotic stock for breed improvement programmes and dairy production. Hoogstraal's 1956 book on ticks of the Sudan has been a milestone, not just for our knowledge on Sudanese ticks but on African ticks in general.

Ticks cause direct losses: 
- loss of blood resulting in anaemia, when present in large numbers;

- metabolic disorders responsible for loss in production;

- wounds leading to secondary abscesses, damaged teats and myiasis;

- lower value of damaged hides and skins;

- certain species inject toxins causing for example tick paralysis and sweating sickness.

Ticks may cause immunodepression, and the bacterial skin disease dermatophilosis is much more severe in the presence of African Amblyomma ticks. This association has been clearly shown to exist in Nigeria and in the Caribbean (Plowright, 1956; Butlen, 1975). Severe forms of this disease are particularly common in the Nuba Mountain areas of Kordofan in zebu herds of the Baqqara during the rains and it is interesting to note that the nomads accuse $A$. variegatum of being the cause.

Ticks are even more important as vectors of tick-borne livestock diseases, caused by viruses, rickettsiae, bacteria and protozoa.

Theileriosis is probably the most important bovine tick - borne disease in the Sudan.T. ANNULATA, $T$. parva, $T$. mutans and $T$. velifera have been identified in caltle in the country, and $T$. lestoquardi (synonym T.hircl) in sheep. T. mutans of cattle is widespread, but is not thought to be of pathological importance in the Sudan. $T$. velifera is non-pathogenic.

Bovine theileriosis was first reported in Sudan in 1908.

Theileria annulata is transmitted by ticks of the genus Hyalomma, the chief vector being $H$. anatolicum anatolicum. The disease caused is variously called mediterranean or tropical theileriosis and occurs in northern and central Sudan. Although serological evidence for its occurrence in southern Sudan has also been presented (Morzaria et al., 1981), this could not be confirmed in further tests at Utrecht (the Netherlands); using antigens of the various species of Theileria on the same sera, the positive reactions to $T$. annulata antigen in southern Sudan appear to have been due to cross-reactions with T. mutans and T. parva (N.M. Perié, F. Jongejan, G. Uilenberg, unpublished data). Moreover, the chief vector $H$. a. anatolicum is not found south of Wad Medani in Blue Nile province (Anonymous, 1983). 


\section{ANIMAL HEALTH}

DISTRIBUTION OF G. MORSITANS IN SOUTH WESTERN DARFUR,

BASED ON UILENBERG (1960 a), YAGI AND ABDEL. RAZIG (1972), ABDEL RAZIG AND YAGI (1973), AND HALL et al. (1984).

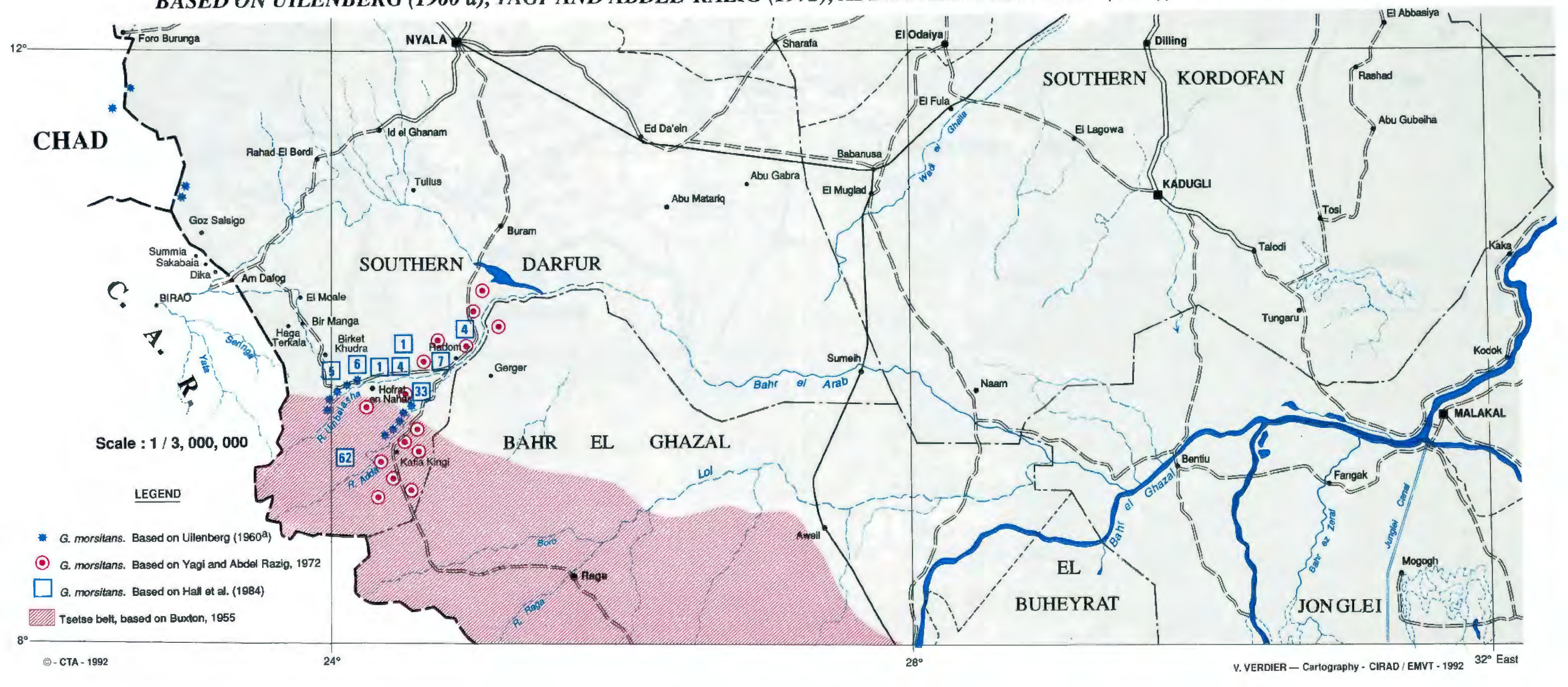




\section{ANIMAL HEALTH (CONTINUED)}

T. parva, the causal agent of East Coast fever, transmitted by Rhipicephalus appendiculatus, is known to occur in southern Equatoria since 1950 (Hoogstraal, 1956). The present northern limit of its distribution is not well-defined and serological evidence again is unreliable because of crossreactions with other species. The hot plains further to the north are likely to limit the distribution of its vector.

T. lestoquardi was diagnosed in sheep in 1986. It can be transmitted by $H$. a. anafolicum and may cause a problem in lambs.

Tropical theileriosis does nol constitute a major problem in indigenous cattle which possess a degree of innate resistance; their calves in endemic areas are resistant. However, T. annulata is highly pathogenic to exotic Friesian or Friesian/Kenana cross-breds, with a high morlality rate (Anonymous, 1983).

Other tick-borne diseases include heartwater (Cowdria ruminantium infection), transmitted by Amblyomma spp., which affects cattle, sheep and goats in large parls of the Sudan. It appears to be particularly prevalent in Kassala and Blue Nile provinces, where A. lepidum seems to be a particularly effective vector. Indigenous breeds in endemic areas have acquired considerable resistance because of long natural selection, but heavy losses in local small ruminants have been reported from Kassala province (Karrar, 1960). Babesioses and anaplasmoses of cattle and small ruminants do not appear to be a major problem in the Sudan, local breeds are resistant, especially when young. When nutrition is deficient (dry season) or intercurrent diseases have an immunodepressive effect (Irypanosomosis), relapses of anaplasmosis or babesiosis may occur and contribute to anaemia. Babesia bovis is the cause of sporadic fatal cases of cerebral babesiosis in nomadic cattle in western Sudan (G. Uilenberg, unpublished observations, 19581960), presumably when they encounter rare scattered populations of the vector Boophilus annulatus; the far more common Boophilus decoloratus is a vector of Babesia bigemina only, not of $B$. bovis

Equines are affected by babesioses, infection with $B$. equi being the greatest problem. Ticks of the genera Rhipicephalus and Hyalomma are vectors in the Sudan. Camels are not known to be affected by tick-borne diseases in the country, but suspected tick paralysis has been reported (Musa and Osman, 1990)

\section{Gastro - intestinal parasites}

Domestic animals in the Sudan are host to very large numbers of helminths, as elsewhere in Africa. We mention in particular the high incidence of fasciolosis (Fasciola gigantica) and schistosomosis (Schistosoma bovis) in swampy areas and near to rivers, and Haemonchus contortus and Haemonchus longistipes, which may cause heavy losses in small ruminants and camels, respectively. Hydatid cysts (Echinococcus granulosus) are frequent and constitute an important zoonosis.

The effects of helminths on livestock are manifold:

mortality:

total or partial condemnation of meat or viscera;

loss of production (weight loss, growth rate, milk yield, depreciation of animal products);

- reduced resistance to other diseases;

- public health hazards; 


\section{BIBLIOGRAPHY}

Abdel Razig (M.T.), YAGI (A.I.) - The distribution and advance of Glossina mörsitans in southern Darfur district, Sudan.

Bull. Epiz. Dis. Afr., 1973, 21: 253-258.

Abdel Razig (M.T.), Yagi (A.I.), Howell (D.E.) - Eradication of Glossina morsitans ugandensis Vanderplank, in Jur Narrows of the Sudan.

Sudan J. vet. Sci. Anim. Husb., 1968, 9: 412-444.

Butler (M.C.) - Dermatophilosis of cattle, sheep and goats in St. Lucia.

State vet. J., 31: 279-283.

Buxton (P.A.) - The natural history of tsetse flies. An account of the biology of the genus Glossina (Diptera). London, H.K. Lewis \& Co Ltd, 1955. 816 p. +47 plates.

El Karib (A.) - Animal trypanosomiasis in the Sudan.

Sudan J. vet. Sci. Anim. Husb., 1961, 2: 39-46.

El Karib (A.), Ford (E.J.H.) \& Wilmshurst (E.C.) - Studies on ethidium bromide. V. The treatment of cattle infected with resistant strains of Trypanosoma congolense.

J. comp. Path., 1954, 61: 187-194.

FAO - Tick and tick-borne disease control. The Sudan.

Rome, FAO. 1983. Technical Reports 1, 2, 3; Terminal Report. (AG:GCP/SUD/024/DEN)

Hall (M.J.R.), Kheir (S.M.), Rahman (A.H.A.), Noga (S.) - Tsetse and trypanosomiasis survey of southern Darfur Province, Sudan. I. Bovine trypanosomiasis.

Trop. Anim. Hlth Prod., 1983, 15: 191-206.

Hall (M.J.R.), Kheir (S.M.), Rahman (A.H.A.), Noga (S.) - Tsetse and trypanosomiasis survey of southern Darfur Province, Sudan. II. Entomological aspects.

Trop. Anim. Hlth Prod., 1984, 16: 127-140.

Hoogstraal (H.) - African lxodoidea. I. Ticks of the Sudan.

Cairo, US Naval Medical Research Unit n`3. 1956. (Research Report NM 005 050.29.07).

Karrar (G.) - Rickettsial infection (heartwater) in sheep and goats in the Sudan.

Brit. vet. J., 1960, 116: 105-114

Morzaria (S.P.), Tatchell (R.J.), Minor (R.), Pedersen (V.), Julla (I.) Rahim (A.), Dyson (D.), Van Aarle (P.A.M.) - Preliminary studies on the epidemiology of theileriosis in eastern equatoria province of the Sudan. In: Irvin (A.D.), Cunningham (M.P.) \& Young (A.S.), eds. Advances in the control of theileriosis. Proc. Int. Conference, Nairobi, ILRAD, 9-13th February 1981. The Hague, Martinus Nijhoff Publ., 1981. P. 83-85. (Coll. Current topics in veterinary medicine and animal science, vol. 14).

Musa (M.T.) \& Osman (O.M.) - An outbreak of suspected tick paralysis in one-humped camels (Camelus dromedarius) in the Sudan.

Revue Elev. Méd. vét. Pays trop., 1990, 43: 505-510.

Uillenberg (G.) - Summarizing report of Veterinary Research Officer Nyala to Assistant Director (Research). Khartoum, Department of Veterinary Services, Khartoum. February 1960. 11 p. (Unpublished). 
Uillenberg (G.) - Report on the trypanosomiasis situation in the White Nile area of Blue Nile Province. April 1960. 3 p. (Unpublished).

Uillenberg (G.) - Dourine probably occurring in the Sudan. Tijdschr. Diergeneesk., 1961, 86: 130-133.

Yagi (A.I.) \& Abdel Razig (M.E.) - Present status of tsetse flies and its control in the Sudan. 13th Meet. ISCTR. Lagos, OAU, 1971. P. 299-302. (Publication $n^{\circ} 105$ ).

Yagi (A.I.) \& Abdel Razig (M.E.) - Distribution of tsetse flies in southern Darfur district, Sudan. Bull. Epizoot. Dis. Africa, 1972, 20: 287-290.

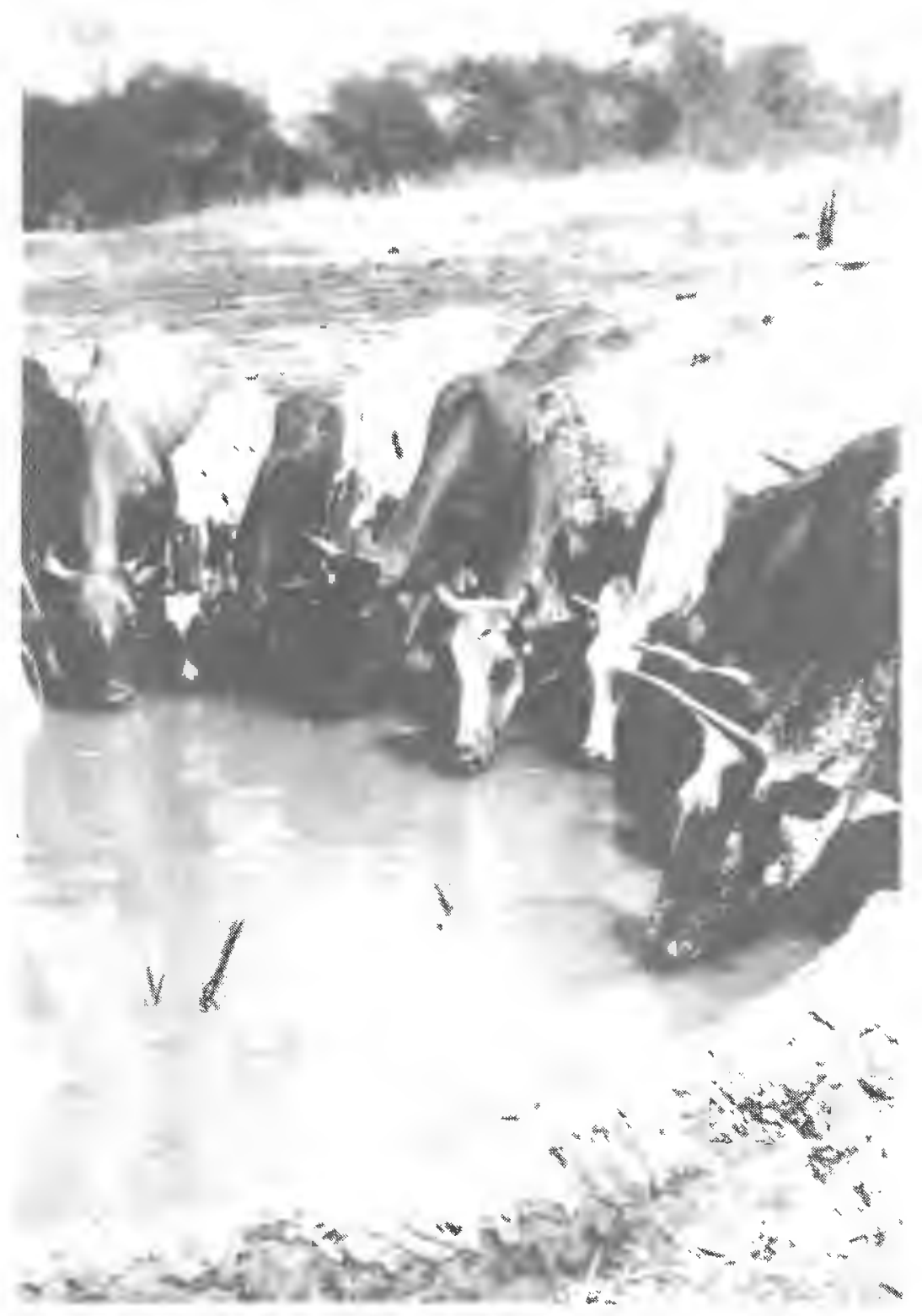




\section{VETERINARY SERVICES}

\section{H. I. KHATAB - M. O. EL SAMMANI}

Veterinary services. Khatab H.I., El Sammani M.O., De Zborowski Isolde. 1993. In : Livestock production and sahelian rangelands potential: Republic of Sudan = Élevage et potentialités pastorales sahéliennes : République du Soudan. Darag A., Lamarque Georges. CIRAD-IEMVT - FRA. Wageningen : CTA-CIRAD-IEMVT, 32-33. ISBN 2-87614-088-8

Government veterinary and animal health services are currently organized within the Ministry of Agriculture, Natural and Animal Resources. Two administrations within this structure are principally concerned with services, while the other one deals with research.

The General Administration for General Services has 700 professional staff. Its sections cover Regional Affairs, Veterinary Supplies, Extension, Khartoum Central Veterinary Hospital, and Omdurman Veterinary Assistants'Training School. The Regional Affairs section is by far the largest and absorbs the bulk of the human (Table 1) and other resources (Table 2). Veterinary infrastructure has increased very rapidly in recent years and there are now five times more veterinary hospitals than there were in 1983: in addition 200 clinics have been established. Junior staff in support of the professionals total 4,000 people. The veterinary services in general are among the most active of the civil service.

Table 1 - Numbers and qualifications of professional staff in animal resources services

\begin{tabular}{l|r|r|r|r|r}
\cline { 2 - 6 } & \multicolumn{5}{c}{ Educational level } \\
\hline Service/Department & \multicolumn{1}{|c}{ Ph.D } & M.Sc./Dip & B.Sc. & Other & Total \\
\hline General/provincial services & 3 & 86 & 504 & 105 & 698 \\
Veterinary Research Laboratories & 34 & 45 & 10 & 120 & 209 \\
Animal production services & 4 & 18 & 65 & 32 & 119 \\
Animal health (epizootic control) & 3 & 23 & 15 & 57 & 98 \\
Hydrobiology/Aquaculture & 1 & 8 & 18 & 70 & 97 \\
Animal production research & 10 & 25 & 7 & 23 & 65 \\
Planning and Projects & 2 & 9 & 19 & 2 & 32 \\
Meat hygiene Training Institute & 1 & 1 & 3 & 6 & 11 \\
Headquarters & 1 & 1 & 3 & - & 5 \\
\hline Source: Ministry of Agriculture 1990 &
\end{tabular}

Table 2 - Animal health personnel and infrastructure in the Sudan

\begin{tabular}{|c|c|c|c|c|c|c|c|c|}
\hline \multirow{2}{*}{ Service and services } & \multicolumn{8}{|c|}{ Regions } \\
\hline & Darfur & Kordofan & Central & Eastern & Khartoum & Northern & Southerm & Total \\
\hline Veterinary services & 37 & 81 & 107 & 67 & 76 & 42 & 19 & 429 \\
\hline Hospitals & 16 & 14 & 14 & 7 & 3 & 4 & 6 & 58 \\
\hline Clinics & 33 & 64 & 64 & 31 & 1232 & $?$ & 236 & \\
\hline \multicolumn{9}{|l|}{ Epizootic control } \\
\hline Vaccination teams & 44 & 3 & 33 & 14 & 8 & 6 & 21 & 156 \\
\hline Serosurveillance teams & - & - & - & - & 6 & m & - & 6 \\
\hline \multicolumn{9}{|l|}{ Research } \\
\hline Central Laboratory & * & - & - & - & 1 & - & - & 1 \\
\hline Regional Laboratories & 1 & 1 & 1 & 1 & - & - & 3 & 7 \\
\hline \multicolumn{9}{|l|}{ Quarantine/meat hygiene } \\
\hline Stations & - & 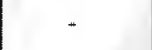 & - & 1 & 1 & 1 & - & 3 \\
\hline Check points & 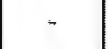 & - & " & 5 & 6 & 3 & $-\cdot$ & 14 \\
\hline Abattoirs & 11 & 20 & 31 & 16 & 16 & 26 & 16 & 136 \\
\hline Veterinary Livestock Units & 6248 & 5194 & 5423 & 1978 & 200 & 411 & 8938 & 28390 \\
\hline TLU per vet/100 & 169 & 64 & 51 & 30 & 3 & 169 & 470 & 66 \\
\hline
\end{tabular}


Vaccination figures are an indication of this activity (Table 3). It should be noted however that the popularity of vaccination is undoubtedly in direct proportion to the minimal cost to the pastoralist (compared to the real cost to the Government) and the free services at clinics and hospitals are also an incentive to go there for treatment. Annual vaccinations against Fowl Pest (Newcastle Disease) total about four million, against Fowl Pox they are 800 thousand and against Gumboro and Marek's Diseases about 280 thousand. The Central Veterinary Laboratory at Soba near Khartoum is a regional production centre and most vaccines used in the country are produced there (Table 4). Production for Sudanese use is purportedly geared to each year's identified needs.

A relatively recent development has been the establishment of veterinary pharmacies. These are private establishments, and in competition with the state services, but do comparatively well in view of the fact that the state is often unable to supply the required drugs. The problems that pharmacies believe they encounter include lack of foreign currency, unlicensed drug sales and use, high sales prices imposed by government, smuggling, and high taxes. The main demand is for antibiotics, anthelmintics and the trypanocidal drugs.

Livestock research is carried out by the Animal Production Research Administration. There are stations for Butana cattle at Atbara and for Kenana cattle at Um Benein. The station at Ghazala Gawazat that was for Western Baqqara cattle is now under the control of the Western Savanna Agricultural Research Project. Dairy research is carried out at the National centre at Shukaba in the Gezira. Animal production research is also undertaken at Khartoum and the Gezira Universities.

Table 3 - Number of animals vaccinated against various diseases in 1988-1989

\begin{tabular}{l|r|r|r|r|r}
\hline \multirow{2}{*}{ Regions } & \multicolumn{5}{|c}{ Diseases } \\
\cline { 2 - 6 } & \multicolumn{1}{|c|}{ Rinderpest } & \multicolumn{1}{c}{ CBPP } & Anthrax & $\begin{array}{c}\text { Haemorrhagic } \\
\text { Septicaemia }\end{array}$ & Black Quarter \\
\hline Northern & 30100 & 200 & 250 & 240 & \\
Eastern & 1310850 & 56800 & 155250 & 80640 & 1440 \\
Khartoum & 420250 & 8800 & 234000 & 105000 & 41280 \\
Central & 1586600 & 76000 & 156125 & 153600 & 139920 \\
Kordofan & 1465100 & 75500 & 118000 & 134880 & 137160 \\
Darfur & 510300 & 266800 & 95000 & 102840 & 70320 \\
Total & 5323200 & 484100 & 758625 & 577200 & 390120 \\
\hline
\end{tabular}

Table 4 - Number of vaccines produced at the Central Veterinary Laboratory in selected years

\begin{tabular}{l|r|r|r|r|r}
\hline \multirow{2}{*}{ Years } & \multicolumn{5}{|c}{ Vaccine type } \\
\cline { 2 - 6 } & \multicolumn{1}{|c}{ Rinderpest } & \multicolumn{1}{c}{ CBPP } & Anthrax & $\begin{array}{r}\text { Haemornagic } \\
\text { Septicaemia }\end{array}$ & Black Quarter \\
\hline $1974-1975$ & 2342400 & 132375 & 1321050 & 1532560 & 424890 \\
$1977-1978$ & 5006200 & 31900 & 1130875 & 2049880 & 232320 \\
$1980-1981$ & 5412300 & 1286720 & 1312375 & 2043840 & 775070 \\
$1983-1984$ & 7686450 & 606900 & 657300 & 1750800 & 607440 \\
$1986-1987$ & 5784150 & 912500 & 1036050 & 1256760 & 78840 \\
$1987-1988$ & 4932800 & 326800 & 1445125 & 1333680 & 197400 \\
$1988-1989$ & 5661200 & 521300 & 818750 & 654120 & 394680 \\
\hline
\end{tabular}




\section{LIVESTOCK MARKETING AND MARKETS}

\section{Marketing systems}

Sudanese livestok owners keep only those livestock that are productive, whether this be for reproduction, meat, milk or transport. The rest are sold or used for home consumption, annual offtake being about $4 \%$ for camels, $8 \%$ for cattle and $25-30 \%$ for sheep and goats. The export trade is an important source of revenue. Two major companies handle the majority of animals: one of these specializes in camel exports to Egypt and (for the best racing camels) to Saudi Arabia; the other mainly exports sheep to the major Arab centres abroad. The "official" export trade comprising animals with export licences and for which proper accountability is required represents only a small fraction of the total trade, perhaps 10 to $24 \%$ depending on the species. Transactions are usually settled in cash as a result of direct bargaining. Auction sales are almost unknown. Intermediaries play an important role in the trade, providing various forms of credit but above all guaranteeing the ownership of the animals and the right to sell.

Animals which go through markets are subject to a sales tax, imposed by the District Council at local levels and by various other statutory bodies. In some areas this is an important part of local government revenue.

Systems of marketing differ somewhat, depending on the species.

\section{Sheep}

For sheep factors which come into play include the condition of the animal, the distance to be trekked, the state of the export market, the usual laws of supply and demand, and the need for cash. The main period for normal sheep sales is October-December: the family is at a convenient point in the annual cycle, animals are in good condition, and there is adequate feed and water on the stock routes. The annual feast of Id el'Adha also plays an important role in the marketing and slaughter of sheep, it being expected of every family to sacrifice at least one sheep at this time.

The first point of sale is directly off the range or at a local market. Previous mutual exchanges between buyers and sellers is important and buyers, whether small or large scale private, company agents or brokers, are expected to have an intimate knowledge of the area in which they operate and the factors which currently affect the market. One system of purchase involves outright payment at the time of sale while another, known as "el fasi", provides an immediate part payment to the seller followed by a second one on final disposal. The latter case obviously needs mutual confidence between buyer and seller and is often the preferred method when there is a glut of animals on the market.

\section{Camels}

The camel marketing system is essentially geared towards exports to Egypt, with some going to Libya and, as already stated, there is a specialist trade to Saudi Arabia. The parties involved include pastoralists themselves, local merchants, wholesale exporters and Egyptian traders. A quota system operates in theory, a number of animals being assigned to each region each year in relation to the actual or expected demand. There are peak buying periods at the end of the dry season but there is a constant low level of trade as herds (the sale animals being gathered into a unit known as a "dakobat") are built ready for the long trek. The part payment/credit system is the norm in camel sales.

\section{Cattle}

Until recently, the "abbala" groups owned considerable numbers of cattle. In the past cattle were sold at the same markets as sheep and camels, and were bought mainly by local traders, the major trade in cattle being carried out in the "baqqara" areas. "Abbala" cattle did, however, supply a considerable proportion of the internal demand in their own areas. Most cattle were sold in the cool winter season while still in good condition but in the face of a declining feed resource.

In the "baqqara" areas cattle begin to be gathered into trek herds as early in the wet season as possible. The long treks to the main marketing areas or to the export holding points have to be achieved before the water on the trek routes dries out and while there is still some feed available. In the 1980s there have been some attempts to modernize this trade with the introduction of special stock trains by the Railways Administration in collaboration with the marketing agencies but the system is not always very efficient and is also costly. 
The Livestock Meat and marketing Commission was established to organize marketing at the national level and is linked to the local markets through regional offices. Its specific functions are:

- formulation of internal and external marketing plans and provision of advice to government, producer and consumer;

- provision of services and facilities to traders and agents in order to promote the industry;

- to balance the internal and external demands for livestock and meat;

- and carry out research and studies to provide information on supply and demand for both internal and export markets.

Steps are being taken at present to transform the Corporation into a private company.

\section{Goats}

Goat marketing is less well-structured than for other species. Sales are made at any time, in response to needs for small amounts of cash, and females are sold as milk animals as well as for slaughter. Their share of the commercial internal meat market has increased considerably since the drought of the mid-1980s. Women are involved in goat marketing much more than they are with other species.

\section{Markets}

The major markets in the Eastern Region are New Halfa (which has expanded greatly in the last 10 years and is now a principal market for all types of stock), Gedaref, Kassala and Tambul. Gedaref is also a multi-species market while Gedaref mainly deals in sheep and goats. Tambul is known for small ruminants and camels but has been superseded to some extent recently by New Halfa.

There are many intermediate markets in Northern Kordofan, especially during the early dry season, these being the ones which mainly deal with sheep. Mazroub and Um Badr deal mainly in camels while $\mathrm{El}$ Obeid is a major collection market for all species.

In Northern Darfur the intermediate markets are mainly in the north-western areas, both Mellit and Kutum being important. Mellit is also an important collecting centre for camels and sheep, as is Um Keddada. El Fasher is particularly known for camels and sheep but relatively large numbers of cattle also accumulate here.

In Southern Darfur, Nyala is by far the most important market for cattle and sheep, and indeed one of the major markets in the country. Other centres include Ed Dae'in, Kas and Buram.

The terminal markets are in the Khartoum area and at Port Sudan. Omdurman is by far the largest. The market at Omdurman is largely manipulated by a small coterie of merchants who between them, and directly or indirectly, control more than half of the total trade. Many animals from Omdurman are put through a fattening period of 4-6 weeks in feed lots before final export or slaughter.

\section{Stock routes}

The areas where livestock populations are largely in excess of local needs are mainly the western 
provinces. The LMMC runs trains from Southern Darfur to Omdurman and Port Sudan. There are also some recent developments involving the use of trucks from other areas to Omdurman and from Ondurman to Port Sudan.

The greater part of livestock movement, however, is still on the hoof. The time of, and the time taken in, trekking depend on the location and distance of the gathering centres from the terminal markets and the state of the feed resources on the route. There are several main trek routes whose main function is to get animals from the west to the east.

\section{The northern routes}

The major sheep and camel routes from Northern Darfur to Omdurman start in El Fasher. They pass through El Abyad, Abu Odam, Sodiri, Shershar, Gabrat eshh Sheikh, Um Inderaba and on to Omdurman. Livestock make use of the short rainy season to travel northward and then eastward. The southern routes

A major stock route follows the line of rail for much of the way from Nyala to Omdurman. It passes through El Obeid and serves the "baqqara" tribes of Southern Darfur, Southern Kordofan and White Nile. Both this and the northern route are extended eastward to Port Sudan but most livestock now move on this stretch by truck or train.

\section{The Egyptian camel route}

Camels from Northern Darfur still follow the ancient "darb el arbein" or Forty Days Road. Another major route which also serves camels coming from Northern Kordofan passes through Um Badr, Mazrub, Ed Debba, and Dongola before crossing over into Egypt. Some camels from Kassala also trek northwards via Ed Debba.

\section{Offtake}

The official figures of sales and estimates for home consumption must be treated with reserve, and it is generally admitted that much of marketed offtake is never officially recorded. It is also sometimes difficult to calculate offtake and sales, as many more animals are present at markets than ever appear to be sold (Table 5): these figures do perhaps show the willingness of livestock owners to market their animals if the price and other conditions are right. Factors that have undoubtedly contributed to increased offtake in recent years include population increase sedentarization, urbanization, and education and improved dietary awareness.

Table 5 - Numbers of livestock attending and sold at major regional markets in 1986-1987

\begin{tabular}{|c|c|c|c|c|c|c|c|c|c|c|}
\hline \multirow{3}{*}{ Markets } & \multicolumn{10}{|c|}{ Species } \\
\hline & \multicolumn{2}{|c|}{ Camel } & \multicolumn{2}{|c|}{ Cattle } & \multicolumn{2}{|c|}{ Calf a) } & \multicolumn{2}{|c|}{ Sheep } & \multicolumn{2}{|c|}{ Goat } \\
\hline & Offer & Sales & Offer & Sales & Otfer & Sales & Otfer & Sales & Offer & Sales \\
\hline El Fasher & 22900 & 5349 & 16545 & 5282 & 349 & 168 & 162940 & 64385 & 64272 & 11,342 \\
\hline Mellit & 22500 & 5348 & 473 & 241 & 89 & 41 & 66395 & 31208 & 15021 & 3,730 \\
\hline Nyala & 15617 & 9529 & 57597 & 47453 & 9341 & 7172 & 65202 & 28864 & 34399 & 14,730 \\
\hline Ed Dae"in & 283 & 207 & 21400 & 15939 & 6992 & 4870 & 49520 & 29186 & 27700 & 14,659 \\
\hline Kosti & 1294 & 490 & 89557 & 57433 & 13663 & 8376 & 118232 & 83360 & 97235 & 40,560 \\
\hline El Obeid & 20442 & 5912 & 62285 & 38494 & 21881 & 8812 & 158466 & 70107 & 93273 & 35,426 \\
\hline Sennar & 2177 & 605 & 16676 & 1023 & 4884 & 3297 & 113483 & 67139 & 42739 & 26,569 \\
\hline Port Sudan & 3765 & 2139 & 20293 & 14019 & 4336 & 2474 & 27047 & 7176 & 20494 & 5,627 \\
\hline Rabak & 4220 & 1092 & 17272 & 5884 & 5674 & 1921 & 302966 & 102731 & 43044 & 19,957 \\
\hline Total & 93138 & 30671 & 302098 & 185768 & 67319 & 37131 & 1062251 & 484156 & 43817 & 172,60 \\
\hline
\end{tabular}

Note: a) calves are animals up to 4 years old

Increasing awareness in the monetary and economic value of livestock results from, and is encouraged by, several factors. These include:

- the active market and the high prices to be obtained for sheep which has created opportunities to exchange camels for sheep;

- development of commercial attitudes by owners, many of whom buy small lots of animals to bring-on during the rains to sell to large scale traders in the dry season; 
- stratification of producers into wealthy, average and poor groups;

- the high-priced export market, yielding bigger margins to producers and traders (but which in some cases is detrimental to local consumers as it pushes the meat price above their means);

- a high price for good quality rams ("sadeis"), also for export, encouraging a local market for cull ewes as meat animals;

- more efficient marketing systems, encouraged by the export trade, operated by skilled modern managers and to some extent streamlining the system;

- and the limited trade in very high-priced camels for racing, providing hope to everyone that he may eventually sell one of these animals.

Once again it needs to be stressed that official figures for marketing and slaughter are little more than notional. A generally admitted figure for illegal export of sheep is 800,000 animals per year. Returns from abattoirs (Table 6) include only those from the larger centres and many smaller slaughter slabs and the whole of household consumption is excluded.

Market movements related to offtake over the last few years can be summarized under a few main headings:

- a marked reduction in the number of sheep slaughtered in the Sudan resulting from diversion of animals to the high-priced export market;

- a rise in animals marketed in 1984 due to the drought, with a concomitant drop in livestock (and meat) prices;

- a drop in the number of animals marketed in 1985 and 1986, consequent on and as a reaction to the forced selling in 1984;

- increased sales (and consumption of meat) of camels and goats in recent years especially away from the main centres, probably because large numbers of cattle and sheep are being exported.

It is worth noting that milk is being imported to fulfil the present demand.

Table 6 - Animals slaughtered at principal abattoirs 1986-1987

\begin{tabular}{|c|c|c|c|c|c|c|c|c|c|}
\hline \multirow{3}{*}{ Regions } & \multicolumn{9}{|c|}{ Species } \\
\hline & \multicolumn{2}{|c|}{ Camel } & \multicolumn{3}{|c|}{ Cattle } & \multicolumn{2}{|c|}{ Sheep } & \multicolumn{2}{|c|}{ Goat } \\
\hline & Male & Female & Male & Female & Calves & Male & Female & Male & Female \\
\hline Northern & 1738 & 268 & 14442 & 1216 & 1170 & 32586 & 2812 & 1462 & 230 \\
\hline Darfur & 3064 & 051 & 8598 & 2999 & 162 & 10499 & 1764 & 20262 & 5054 \\
\hline Khartoum & 2353 & & & 110490 & 49470 & 2235 & & & \\
\hline Central & 5604 & 7745 & 75750 & 15056 & 5748 & 68805 & 17275 & 33010 & 1742 \\
\hline Eastern & 4267 & 2086 & 27247 & 20617 & 9413 & 67119 & 22505 & 24110 & 1112 \\
\hline Kordofan & 2251 & 903 & 17982 & 6732 & 4703 & 13277 & 5008 & 29920 & 10789 \\
\hline Total & \multicolumn{2}{|c|}{31330} & \multicolumn{2}{|r|}{322320} & & \multicolumn{2}{|c|}{291120} & \multicolumn{2}{|c|}{129926} \\
\hline
\end{tabular}

\section{Price trends}

The effects of drought during the 1980s have been the major factor influencing the sale price of animals. Prices rose steadily during the 1970 s and early 1980s, generally in line with inflation, but collapsed dramatically in 1983. Prices rose sharply again in following years as pastoralists attempted to build up their herds and as the relative value of livestock to millet (the staple cereal) returned to pre-drought levels (Table 7). Livestock sales prices increased several fold in the succeeding years until Government intervened to control the meat price in Khartoum: intervened to such an extent, in fact, that meat was sold at less in Khartoum than its value in the producing areas in the west. In 1987 prices paid to producers in Southern Darfur dropped (this area having been less drastically affected by the drought than some others) while prices in Omdurman were very high. 


\section{VETERINARY SERVICES (CONTINUED)}

Table 7 - Trends in livestock sale prices (ESud/head) from 1984 to 1987

\begin{tabular}{|c|c|c|c|c|c|c|c|c|}
\hline \multirow{3}{*}{ Year } & \multicolumn{8}{|c|}{ Market and species } \\
\hline & \multicolumn{2}{|c|}{ Wyala } & \multicolumn{2}{|c|}{ El Fasher } & \multicolumn{2}{|c|}{ El Obald } & \multicolumn{2}{|c|}{ Omdurman } \\
\hline & Cattle & Sheep & Cattle & Sheep & Cattle & Sheep & Cattle & Sheep \\
\hline 1984 & 254 & 39 & 289 & 74 & 292 & 51 & 623 & 140 \\
\hline 1985 & 185 & 43 & 196 & 65 & 368 & 74 & 788 & 208 \\
\hline 1986 & 983 & 156 & 2235 & 184 & 916 & 202 & 1374 & 450 \\
\hline 1987 & 823 & 111 & 1185 & 230 & 1255 & 230 & 1653 & 269 \\
\hline Ratio & & & & & & & & \\
\hline 1987: 1984 & 3.24 & 2.85 & 4.10 & 3.11 & 4.30 & 4.51 & 2.65 & 1.92 \\
\hline
\end{tabular}

The price trends from 1984-1987 reflect a classic producer response to drought: forced selling at the height of the crisis, followed by reluctance to sell and attempts to build up animal numbers for the next cycle. The areas worst affected by the drought followed most closely this paradigm with 1987 prices being relatively higher in the worst affected areas of Kordofan and the central area (Table 8 ) than in the west. The difference of $30 \%$ in relation to the national average sales price is less than might be expected and is due in part to Government intervention and to traders having to reduce their margins. Demand for sheep and goats remained strong in the west during the late 1980 s but cattle and camels were favoured in the centre and east. Cattle and sheep prices at the terminal export markets remained reasonable. 
Table 8 - Variations in regional livestock prices (National index $=100$ ) in 1987

\begin{tabular}{l|r|r|r|r|r}
\hline \multirow{2}{*}{ Market } & \multicolumn{4}{|c}{ Species } \\
\cline { 2 - 6 } & \multicolumn{4}{|c}{ Camel Catte Calves } & Shoep \\
\hline Nyala, Southern Darfur & 89 & 64 & 93 & 48 & 83 \\
Ed Dae'in, Southern Darfur & 84 & 88 & 73 & 118 & 151 \\
Mellit, Northern Darfur & 98 & 80 & 78 & 123 & 119 \\
El Fasher, Northern Dartur & 103 & 92 & 98 & 101 & 111 \\
El Obeid, Kordofan & 117 & 97 & 78 & 101 & 86 \\
Kosti, White Nile & 103 & 96 & 83 & 94 & 86 \\
Rabak, White Nile & 115 & 91 & 64 & 99 & 85 \\
Sennar, Blue Nile & 91 & 164 & 240 & 96 & 92 \\
Port Sudan & & 128 & 94 & 119 & 86 \\
\hline
\end{tabular}

The efficiency of the marketing system in Sudan is intimately linked and affected by the organization of the animal health services and the complicated nature of commercial channels. Veterinary services are to some extent concentrated on the main transport routes, whether these be rail or road or the great trek routes. The large number of markets assists in channelling livestock to these routes and their movement to the final centres of consumption or export. 


\section{BIBLIOGRAPHY}

AAAID - (Arab Authority for Agricultural Investment and Development) - Feasibility study for a feedlot complex project in western - Omdurman, Sudan. Khartoum, AAAID. 1982.

Ahmed A.S., Gotbi O.A. - Export and import of livestock and meat. In the International Symposium on the Development of Animal Resources in the Sudan. Khartoum, Sudan. 1989.

Ahmed Hamza Khalifa - Marketing in the Sudan. In: Ali Mohamed El Hassan, ed.- An introduction to the Sudan economy. Khartoum, University Press, 1976. P. 201-15.

Arab Organization for Agricultural Investment Development - A reconnaissance study of resources and agricultural investment of the eastern and nothern regions of the Sudan. Khartoum, the arab organization for agricultural development. 1983.

Arab organization for Agric. Development, AOAD. Development of livestock and meat marketing. 1983.

Davies H.R.J. - The human factor in development: some lessons from rural Sudan?

Appl. Geogr., 1986a, 6 : 107-21.

Doran A. - Agricultural extension and development: the Sudanese experience.

British Soc. Middle eastern Studies, 1980, 7 : 39-48.

El Fatih Shaaeldin - The evolution and transformation of the Sudanese economy up to 1950. University of Khartoum, Development studies and research centre, 1984. (Monography n_20)

EI Haj Bilal Omer - The Danagla traders of northern Sudan. Rural capitalism and agricultural development. London, Ithaca Press, 1985. 
El Sammani M.O., ed.- El Khuwei-Mazroub-Tinna study area North Central and Messeriya study area. Southern Kordofan. Final Report, Environmental training and management in Africa (ETMA). Environmental management in the Sudan, Institute of environmental studies. University of Khartoum, Sudan, 1985. P. 151-153 and 183-186.

Idris H. - Agricultural research capability and scope in Sudan. Khartoum, National Council for Research. 1975.

Khalifa M.D. EI, ed.- Environmental impact of the southern stock route, Sudan. Institute of Environmental studies. University of Khartoum, 1984.

Khalifa M.D.El. - Marketing Sudanese camels. In : Camel forum, Mogadishu. 1988.

Khatab H.I. - Livestock sector review, Sudan. FAO Report.

MANR - Department of Agricultural Economics. Agricultural prices in Sudan: an historical review and analysis, 1970-1984. Marketing section. Department of Agricultural Economics, Khartoum, MANR, 1985.

Mohamed Hashem Awad - The economics of internal marketing in the Sudan. Ph. D. Thesis. University of London, 1967. (Unpublished).

Musa B.E., Abu Samra M.T., Gotbi O.A. - Camel production marketing and research in the IGADD.

Natural Resources Council. National register of current research. Khartoum, NRC.

Plumbe A.J. - United Kingdom, transport and road research laboratory. The transport and marketing of livestock in the Sudan. Overseas unit working paper $n$ 72. Crowthorne, Berkshire: overseas unit, transport and road research laboratory, U.K.. 1979, vii + $139 p$.

Zohair Mubarak Abdalla - Marketing of livestock in the Sudan. Department of rural economy research bulletin, University of Khartoum, Khartoum, 1974. 
